UNIVERSIDADE DE SÃO PAULO

FACULDADE DE FILOSOFIA CIÊNCIAS E LETRAS DE RIBEIRÃO PRETO DEPARTAMENTO DE PSICOLOGIA E EDUCAÇÃO

PROGRAMA DE PÓS-GRADUAÇÃO EM PSICOLOGIA

MARYSTELLA CARVALHO ESBROGEO

\title{
Avaliação da Orientação Profissional em grupo: o papel da informação no desenvolvimento da maturidade para a escolha da carreira
}

Dissertação de Mestrado apresentada ao Programa de Pós-Graduação em Psicologia da Faculdade de Filosofia, Ciências e Letras de Ribeirão Preto, Universidade de São Paulo, para obtenção do título de Mestre em Ciências.

Área de Concentração: Psicologia. 
MARYSTELLA CARVALHO ESBROGEO

\section{Avaliação da Orientação Profissional em grupo: o papel da informação no desenvolvimento da maturidade para a escolha da carreira}

Dissertação de Mestrado apresentada ao Programa de Pós-Graduação em Psicologia da Faculdade de Filosofia, Ciências e Letras de Ribeirão Preto, Universidade de São Paulo, para obtenção do título de Mestre em Ciências.

Área de Concentração: Psicologia.

Orientador: Profa. Dra. Lucy Leal Melo-Silva. 
AUTORIZO A REPRODUÇÃO E DIVULGAÇÃO TOTAL OU PARCIAL DESTE TRABALHO, POR QUALQUER MEIO CONVENCIONAL OU ELETRÔNICO, PARA FINS DE ESTUDO E PESQUISA, DESDE QUE CITADA A FONTE.

Esbrogeo, Marystella Carvalho

Avaliação da Orientação Profissional em grupo: o papel da informação no desenvolvimento da maturidade para a escolha da carreira. Ribeirão Preto, 2008.

185 p. : il. ; 30cm

Tese de Mestrado, apresentada à Faculdade de Filosofia, Ciências e Letras de Ribeirão Preto/ USP. Área de concentração: Psicologia.

Orientador: Melo-Silva, Lucy Leal.

1. Informação Profissional. 2. Maturidade profissional.

3. Orientação Profissional. 


\section{FOLHA DE APROVAÇÃO}

Marystella Carvalho Esbrogeo

Avaliação da Orientação Profissional em grupo: o papel da informação no desenvolvimento da maturidade para a escolha da carreira.

Tese apresentada à Faculdade de Filosofia, Ciências e Letras da Universidade de São Paulo para a obtenção do título de Mestre.

Área de Concentração: Psicologia.

Aprovado em:

Banca Examinadora

Prof. Dr.

Instituição:

Assinatura:

Prof. Dr.

Instituição:

Assinatura:

Prof. Dr.

Instituição: Assinatura: 


\section{DEDICATÓRIA}

Dedico este estudo ao meu irmão Walder, grande incentivador intelectual desde os primeiros livros infantis até nossas longas discussões literárias que culminaram neste trabalho acadêmico. Muito obrigada por ser essa pessoa especial, pelo aprendizado em nossas conversas, amizade e principalmente por me ensinar todos os dias como lutar pela vida. 


\section{AGRADECIMENTOS}

No momento precioso de encerramento deste trabalho, meu muito obrigada a todas as pessoas que, direta ou indiretamente, dele participaram. Vivi diálogos internos, momentos solitários de dúvidas e intranqüilidades, contudo sempre amparada pelo companheirismo de determinadas pessoas me auxiliando nessa trajetória que certamente não se encerra aqui.

Em primeiro lugar, gostaria de agradecer aos adolescentes dessa pesquisa que participaram voluntariamente deste estudo. Sem eles seria impossível a realização deste trabalho.

Ao Serviço de Orientação Profissional da Faculdade de Filosofia Ciências e Letras de Ribeirão Preto, que viabilizou a realização dos grupos de Orientação Profissional.

A orientadora Lucy Leal Melo-Silva, pela imensa colaboração, amizade, compreensão na elaboração de todo o trabalho. Agradeço principalmente, pela confiança dispensada nos momentos mais difíceis.

Ao Centro de Pesquisa em Psicodiagnóstico (CPP), e principalmente à professora Sônia Pasian e à Érika T. K.Okino pelas sugestões e auxílio prestado ao longo de todo o projeto.

À professora Maria Odília da Costa de Oliveira Texeira pelas excelentes sugestões durante o Exame de Qualificação e por sua grande disponibilidade em ensinar.

Às psicólogas, observadoras do grupo Operativo, Maria Luiza Junqueira e Carolina Vilela Steffen pela grande colaboração na condução do grupo.

À psicóloga Ingrid Duarte Pinto pela colaboração na análise quantitativa dos dados.

A Geraldo Cássio dos Reis, estatístico, pela colaboração na análise dos dados.

A Norien Marly Rodrigues Rossi, pela revisão do português.

A Márcia Regina Silva, pela revisão das normas de apresentação do trabalho.

Ao meu marido Paulo Henrique Paggioro, pelo companheirismo, carinho e apoio indispensáveis na realização de todas as tarefas.

Aos meus filhos, Murillo e Maurício, por muitas vezes cederem em as suas prioridades, ensinando-me a ver o mundo por diferentes prismas. 
"A vida é como uma conversação ou, mais especificamente, como uma festa a que fomos convidados, mas chegamos tarde. Ao entrar encontramo-nos com as pessoas mantendo animadas conversações sobre toda uma variedade de temas. Aproximamo-nos com um copo de vinho na mão e começamos a escutar as conversas. Logo começamos a participar delas. Antes de acabar a festa, já estamos apaixonadamente envoltos em algumas conversações; sentimos que existe algo que devemos expressar, que há algo que não devemos dizer, que não podemos deixar sem questionar o que alguém disse, mas já é tarde e temos que partir. E vamos, ainda que a festa prossiga e as conversas também ”...

Kenneth Burke (PEARCE, 1996) 


\section{RESUMO}

ESBROGEO, M.C. Avaliação da orientação profissional em grupo: o papel da informação no desenvolvimento da maturidade para a escolha da carreira. Dissertação (Mestrado) Faculdade de Ciências e Letras de Ribeirão Preto, Universidade de São Paulo, Ribeirão Preto, 2008.

Este estudo objetiva avaliar um procedimento de intervenção desenvolvido com adolescentes, em processo de Orientação Profissional, em função das variáveis: (1) informação profissional, (2) maturidade para a escolha da carreira e (3) comunicação e aprendizagem no grupo. Participaram do estudo, 28 adolescentes, de ambos os sexos, provenientes de escolas de Ensino Médio e cursos pré-vestibulares, públicos e/ ou privados, com idade entre 15 e 19 anos, em atendimento no Serviço de Orientação Profissional da FFCLRP/USP. Para fins da intervenção e da obtenção dos dados, os jovens foram distribuídos em dois grupos, conforme maturidade para a escolha da carreira avaliada abaixo da média (Grupo A, n=17) e acima da média (Grupo B, n= 11). Os instrumentos utilizados foram: (1) Questionário de Informação Profissional (QIP): “O que os adolescentes sabem sobre profissões e carreiras?”; (2) Escala de Maturidade para a Escolha Profissional (EMEP), de Neiva e os (3) registros das sessões em grupo operativo. Os referenciais teórico-metodológicos que fundamentam o procedimento de intervenção e subsidiam a análise dos dados são: (1) a estratégia clínica de Bohoslavsky, (2) a abordagem de grupo operativo de Pichon-Rivière e (3) a Teoria Desenvolvimentista da escolha de carreira de Super. Os dados obtidos por meio do QIP (perguntas fechadas) foram tratados e analisados pela estatística descritiva. Comparações pré e pós-intervenção foram realizadas, por meio do Teste não-paramétrico de Wilcoxon e o Teste do $\mathrm{X}^{2}$ de McNemar. Outra comparação foi realizada entre as respostas dos participantes do sexo feminino e do masculino, utilizado o Teste exato de Fisher e o Teste não-paramétrico de Mann-Whitney. As respostas registradas nas perguntas abertas e nos comentários foram analisadas segundo Bardin. Os dados obtidos por meio da Escala de Maturidade para Escolha Profissional (EMEP) foram analisados quantitativamente por meio do Teste de Wilcoxon. E a análise qualitativa do processo grupal foi realizada a partir da síntese dos registros dos grupos operativos, focalizando os vetores de avaliação do Cone Invertido: comunicação e aprendizagem. Os resultados mostram que os participantes não estão bem informados e, que a informação profissional pode ajudá-los na tomada de decisão vocacional. A internet é o recurso mais utilizado pelos adolescentes para a comunicação entre os colegas. As moças, no início do grupo de orientação, buscam mais informações profissionais nos guias e nos livros do que os rapazes. Elas, também, utilizam mais a internet para as pesquisas escolares, enquanto que os rapazes a utilizam mais para jogar. Nos resultados da EMEP, o grupo apresentou diferença significativa com valores superiores na segunda nas sub-escalas: Determinação, Autoconhecimento e Maturidade Total. Ao final do processo de Orientação Profissional em grupo foi observado que os adolescentes estavam buscando mais informações profissionais, e que o grupo favoreceu a comunicação e a aprendizagem para o desenvolvimento da maturidade para a escolha de carreira.

Palavras-chaves: Informação profissional. Maturidade profissional. Orientação profissional. Grupo operativo. Escolha de carreira. 


\begin{abstract}
ESBROGEO, M.C. Evaluation of group Vocational Guidance: the role of information for the development of maturity to choose a career. Dissertation (Master), Faculdade de Ciências e Letras de Ribeirão Preto, Universidade de São Paulo, Ribeirão Preto, 2008.

This study aims at evaluating an intervention an intervention procedure done with adolescents, in Professional Guidance, according to the following variables: (1) professional information, (2) maturity to choose a career, and (3) group communication and group learning. The subjects were 28 adolescents, of both sexes, coming from public and private high schools and university preparation courses, aged between 15 and 19 who were attended at the Vocational Guidance Service at the Faculty of Philosophy, Sciences and Letters at Ribeirão Preto, University of São Paulo (FFCLRP/ USP). The participants were divided into two groups according to maturity: below average (group $A, n=17$ ) and above average (group $\mathrm{B}, \mathrm{n}=11$ ). The instruments used to gather the data were: (1) Questionnaire about Professional Information (QIP): “What adolescents know about jobs and occupations?”; (2) Maturity for Career Choice Scale (MCCS); (3) recordings of group sessions. The theoreticalmethodological frame works that underpinned the intervention procedure and its analysis were: (1) Bohoslavsky's clinical strategy, (2) Pichon-Rivière's Operative Group approach and (3) Super's Development Theory for career choice. The data gathered by means of the QIP (closed questions) were treated and analyzed by descriptive statistics. Comparisons before and after interventions were done by means of the Wilcoxon's non-parametric Test and McNemar's $\mathrm{X}^{2}$ Test. Another comparison was done between the answers of the male and female participants by means of the Fisher's Exact Test and Mann-Whitney's non-parametric Test. The open answers were analyzed by Bardin. The data gathered by means of the MCCS were analyzed quantitatively by means of Wilcoxon's Test. And the analysis of the group procedures was done as based on the synthesis of the group recordings, focusing the evaluation vectors of the Inverted Cone: communication and the learning process. The results showed that the participants were not well informed about career choice and that career information could help them to make a career decision. And the internet is the resource more frequently used by adolescents to communicate with pals. At the beginning of the guiding process, the girls looked for career information in books and guides more than the boys did. The girls also went on the internet to do research and schools take, whereas the boys used it to play. The results from MCCS showed a significant difference for the second application, the values being higher than the first for the following sub-scales: Determination, Self-knowledge and Total Maturity. At the end of the Vocational guiding procedure, the group showed to be looking for more career information than at the beginning and favored communication and learning to mature and to choose a career.
\end{abstract}

Keywords: Career information. Career maturity. Professional guidance. Operative group. Career choice. 


\section{LISTA DE TABELAS}

Tabela 1 - Distribuição dos participantes dos grupos A e B, em função das características sócio-demográficas e do nível de maturidade profissional

Tabela 2 - Distribuição dos integrantes do Grupo A e B em função da Maturidade em cada sub-escala e na Maturidade Total segundo a EMEP

Tabela 3 - Síntese dos temas desenvolvidos no Grupo A e no Grupo B

Tabela 4 - Distribuição (em porcentagem) dos adolescentes (n=28) em função da freqüência de respostas sobre a crença de que os adolescentes estão informados sobre as profissões, em dois momentos do processo (pré e pós).

Tabela 5 - Distribuição (em porcentagem) dos adolescentes $(n=28)$ em função da freqüência de uso do recurso da internet para obter informações profissionais, em dois momentos do processo (pré e pós)

Tabela 6 - Distribuição (em porcentagem) dos adolescentes $(n=28)$ em função da freqüência de uso dos recursos informativos sobre carreiras, em dois momentos da intervenção (pré e pós)

Tabela 7 - Resultados descritivos da utilização dos recursos de guias e livros no início da intervenção, em função do sexo

Tabela 8 - Distribuição dos sites utilizados na internet pelos adolescentes $(n=28)$ no início e ao final da intervenção....

Tabela 9 - Distribuição (em porcentagem) dos adolescentes $(n=28)$ em função da freqüência dos locais de uso da internet, no início e ao final da intervenção.

Tabela 10 - Resultados descritivos quanto ao uso da internet na casa de amigos, ao final da intervenção, em função do sexo.

Tabela 11 - Distribuição (em porcentagem) dos adolescentes (n=28) em função da freqüência dos objetivos com que acessa a internet, no início e ao final da intervenção........116

Tabela 12 - Resultados descritivos sobre o uso da internet para a realização de tarefas escolares no início da intervenção, em função do sexo.

Tabela 13 - Resultados descritivos sobre o uso da internet para jogar e buscar informações sobre a carreira, ao final da intervenção, em função do sexo

Tabela 14 - Resultados descritivos do uso da internet para fazer novos relacionamentos, buscar informações sobre as profissões e universidade, em função da avaliação, no início e ao final da intervenção

Tabela 15 - Distribuição (em porcentagem) dos adolescentes (n=28) na comparação entre os resultados no início e ao final da intervenção, em função das áreas de interesse. 
xviii

Tabela 16 - Resultados descritivos sobre o quanto os jovens têm de informação sobre as profissões (categoria 3), em função do momento, no processo de intervenção.

Tabela 17 - Distribuição (em porcentagem) dos adolescentes (n=28) segundo a fonte de informações, no início e ao final da intervenção

Tabela 18 - Resultados descritivos, na comparação entre o início e o final da intervenção, em função do fornecimento da informação pelos Serviços de Orientação Profissional.

Tabela 19 - Distribuição das respostas (em porcentagem) sobre a natureza do conhecimento dos adolescentes $(n=28)$ e as formas de acesso à Universidade, no início e ao final da intervenção

Tabela 20 - Resultados descritivos da maturidade para a escolha profissional, conforme sub-escalas da EMEP, em função da avaliação no início e ao final da intervenção 


\section{SUMÁRIO}

1. INTRODUÇÃO ......................................................................................................21

1.1 Sociedade da Informação e do Conhecimento ............................................................22

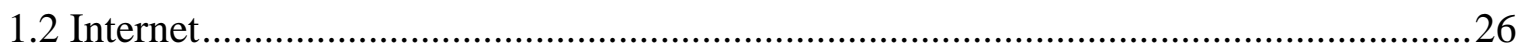

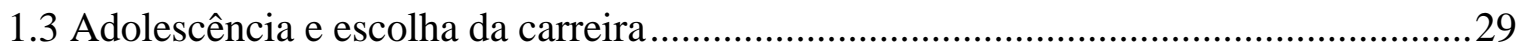

1.4 Orientação Profissional em processos grupais na perspectiva da Teoria de Grupo

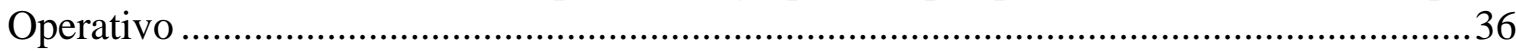

1.5 A Maturidade para a escolha profissional na perspectiva da Teoria

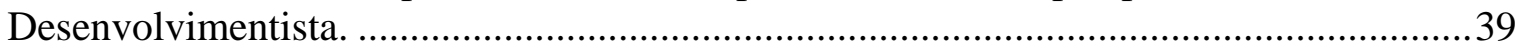

1.5.1 Maturidade para a escolha da carreira: o estado da arte. ...............................48

1.6 A Informação Profissional em processos de Orientação Profissional ...........................52

1.6.1 A Tecnologia da Informação e Comunicação (TIC) na Educação e Orientação Profissional: o estado da arte. ...........................................................61

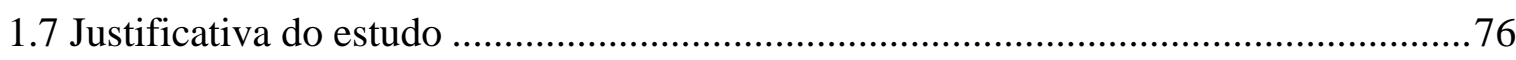

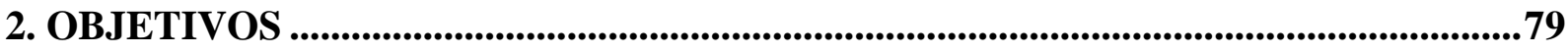

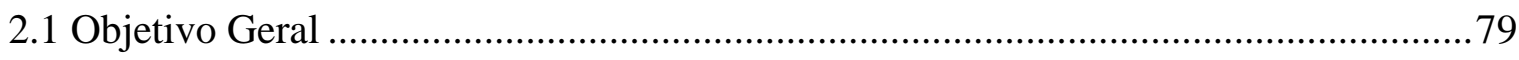

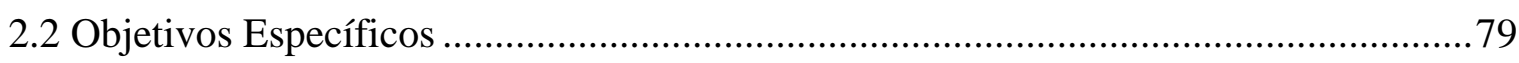

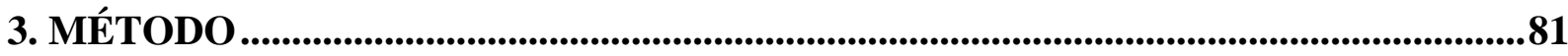

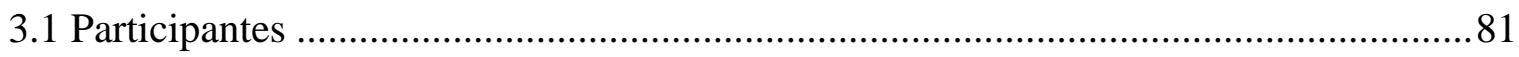

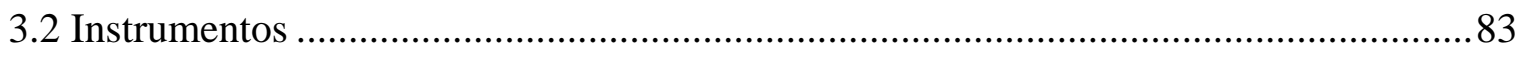

3.2.1 Questionário de Informação Profissional (QIP) ..........................................83

3.2.2 A Escala de Maturidade para Escolha Profissional (EMEP)..........................85

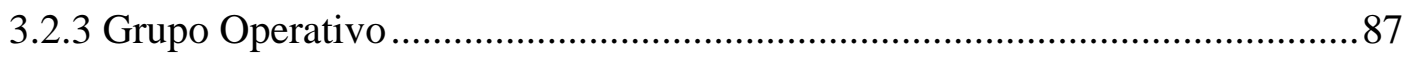

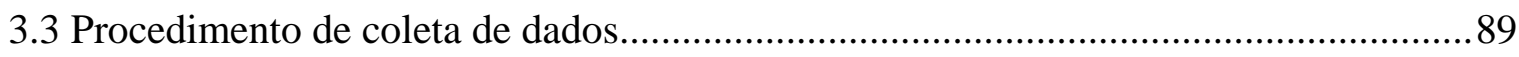

3.3.1 Serviço de Orientação Profissional............................................................... 89

3.3.2 Composição dos grupos para a intervenção .................................................90

3.3.3 O processo grupal em Orientação Profissional..............................................94

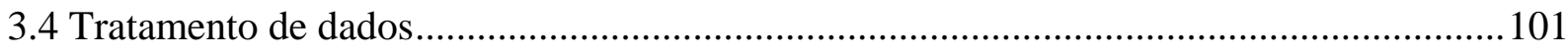

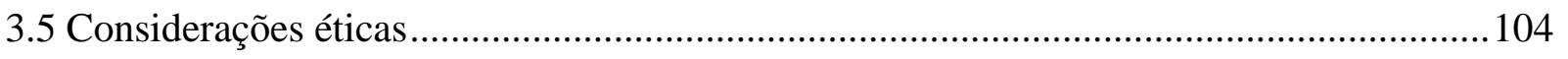

4. RESULTADOS E DISCUSSÃO _....................................................................107

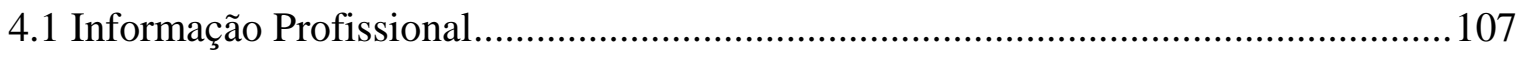

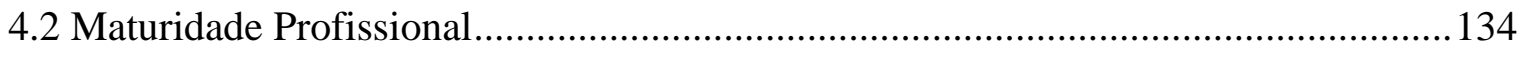

4.3 Comunicação e aprendizagem no processo grupal..................................................139 


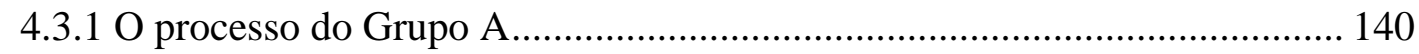

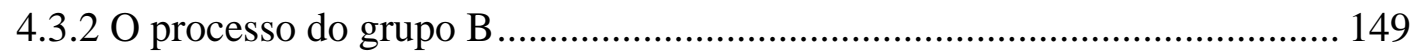

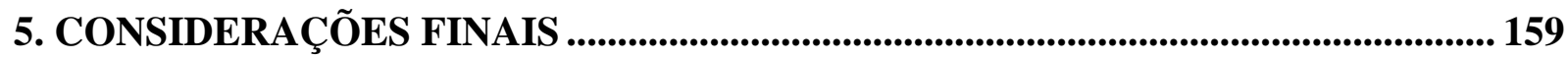

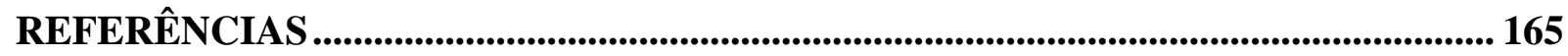

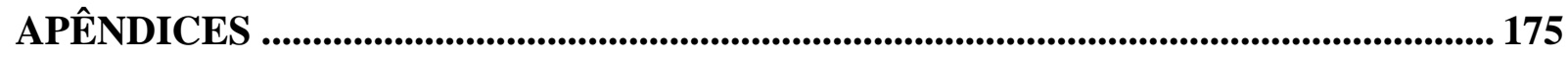

ANEXO 


\section{INTRODUÇÃO}

A humanidade vivencia a chamada era da pós-modernidade marcada por profundas mudanças de paradigmas nas crenças, costumes, ideologias e valores. O advento de novas tecnologias de informação e comunicação tem alterado substancialmente as relações humanas presenciais ou virtuais e o uso do tempo, sobretudo quando se observam as atitudes ${ }^{1}$ dos jovens que se encontram plugados na internet navegando em websites, chats, messenger e orkut.

A fim de estudar o papel da informação profissional no desenvolvimento da maturidade para a escolha da carreira, objeto deste estudo, considerou-se relevante refletir nessa seção sobre a sociedade da informação e do conhecimento (1) no modo de produção capitalista, a partir de meados do século passado até a atualidade. Nesse cenário, a internet (2) ocupa lugar de destaque como um dos representantes desse novo tempo das tecnologias em contínuo desenvolvimento e que, de forma cíclica, promove mais modificações no mercado de trabalho para trabalhadores em diferentes faixas etárias. Sobretudo para adolescentes em situação de escolha da carreira (3). Processos de tomada de decisão constituem objetos de estudo e de intervenção da área da Psicologia, em especial do domínio da Orientação Profissional. As intervenções em Orientação Profissional, muitas vezes, são realizadas em processos grupais (4). Nesse estudo, a compreensão do fenômeno grupal se deu com aportes da teoria de Grupo Operativo. As intervenções psicológicas, que constituem o foco deste estudo, visam o desenvolvimento da maturidade para a escolha profissional (5). A fim de se delinear um estudo ou uma intervenção é preciso buscar o conhecimento produzido. Assim, o estado da arte sobre a dimensão psicológica maturidade (6) constitui outro tópico abordado na introdução.

A maturidade é compreendida neste estudo com base na Teoria Desenvolvimentista da escolha de carreira. A maturidade para a escolha profissional será abordada, priorizando a investigação de um dos seus principais pressupostos: a informação profissional (7) que contribui para a efetivação de uma escolha profissional consciente. É por meio das

\footnotetext{
${ }^{1}$ Atitude é a organização individual de mecanismos psicológicos, inferida do comportamento do indivíduo em face de algum aspecto do mundo que ele distingue dos demais aspectos. Representa o resíduo de sua experiência anterior, com o qual enfoca qualquer situação subseqüente que inclua tal aspecto e que, juntamente com as influências vigentes, determina seu comportamento na situação. As atitudes são permanentes no sentido de que tais resíduos são transferidos para situações novas; e mutáveis na medida em que novos resíduos são adquiridos por experiência em situações novas (Dicionário de Ciências Sociais, 1987, p. 95).
} 
Tecnologias da Informação e da Comunicação (TIC's) que a Educação e a Orientação Profissional (8) facilitam o acesso às informações. Assim sendo, cada tópico é tratado a seguir.

\subsection{Sociedade da Informação e do Conhecimento}

O conhecimento ao longo da história vem passando por mudanças importantes nos sentidos e significados para a sociedade e seus cidadãos. Assim, o significado do conhecimento sempre foi aplicado ao ser, no sentido de ser um bem privado, passa a ser aplicado ao fazer, tornando-se um recurso e uma utilidade, ou seja, um bem público. Na primeira fase da Revolução Industrial, o conhecimento começa então a ser aplicado a ferramentas, processos e produtos. (DRUCKER, 2002).

Na segunda fase da Revolução Industrial, ao final da Segunda Guerra Mundial, observa-se um acentuado progresso no desenvolvimento científico e tecnológico acompanhado de uma explosão de consumo de bens materiais sem precedentes na história. $\mathrm{O}$ conhecimento em seu novo significado passa a ser aplicado ao trabalho, desencadeando a Revolução da Produtividade, com a elevação da produtividade, converte o proletariado na burguesia de classe média (DRUCKER, 2002).

Em contrapartida, a industrialização trouxe também a degradação do meio ambiente, o esgotamento dos recursos não-renováveis e a deterioração da camada de ozônio, mudanças cada vez mais percebidas nos tempos atuais. A Revolução Industrial e os fundamentos do taylorismo ou fordismo geraram a organização do trabalho em linhas de montagem que asseguravam a submissão do trabalhador e traziam maior rapidez na confecção dos produtos a serem postos no mercado, eram os produtos padronizados, produzidos em massa (LYON, 1998).

O modo de produção capitalista passa a exigir especialização, uniformidade e padronização, que se tornaram características comuns da vida moderna. O sistema de produção no século XIX, criado por Taylor na Inglaterra, fundamenta-se na organização científica do processo de trabalho e do controle sobre ele. Nesse modo de produção as tarefas são divididas, cronometradas e inspecionadas com o fim de maximizar a produtividade e o lucro. Nos Estados Unidos o fordismo configurou-se como um modelo de produção equivalente. No final do século XX observa-se uma nova organização do processo de produção, contrapondo-se ao antigo padrão taylorista / fordista. Trata-se do toyotismo, ou 
seja, o modelo de produção baseado na acumulação flexível, no sistema just in time, desenvolvido pela Toyota no Japão. Nessa nova organização do trabalho, modificações são observadas como: introdução de novas tecnologias de produção; flexibilização da produção, reduzindo a homogeneização da força de trabalho; expansão do emprego transitório e atípico; subcontratação ou terceirização de serviços; globalização da economia; privatizações, entre outras mudanças (CAMPERO et. al., 1994). As mudanças não cessam, ocorrem do dia para a noite e interferem no cotidiano dos trabalhadores, dos desempregados e dos que aspiram ao início de uma carreira (MELO-SILVA; JACQUEMIN, 2001). Essas mudanças acarretam modificações no sistema de produção, nas relações de trabalho, na natureza do contrato e nas próprias profissões, algumas em processo de desaparecimento enquanto que outras, de surgimento.

Na atualidade, a partir das modificações citadas, o conhecimento começa a ser aplicado e desenvolvido na própria pessoa que possui determinada informação e a converte em conhecimento para si, sendo essa fase denominada de Revolução da Administração. O conhecimento se torna o único fator de produção, deixando de lado tanto o capital quanto a mão-de-obra (DRUCKER, 2002). Para o referido autor “pode ser prematuro chamar a nossa sociedade de sociedade do conhecimento; até hoje temos apenas uma economia do conhecimento. Mas nossa sociedade certamente é pós-capitalista” (DRUCKER, 2002, p. 18).

A rapidez das mudanças tecnológicas gerou a demanda pelo capital, muito além do que o artesão podia suprir, demandando outras inovações para contemplar as novas necessidades. As inovações da sociedade moderna, denominadas de tecnologia, são inerentes até na terminologia da palavra, no sentido de que combina techne (mistério de uma arte) com logia, o conhecimento intencional, organizado, sistemático. (DRUCKER, 2002).

O desenvolvimento tecnológico leva a um aumento gradativo das profissões relacionadas com a informação, e remete à crença de que o desenvolvimento social caminha de modo ascendente e igualitário. Por outro lado, esse aparente otimismo dá lugar à constatação da permanência do desemprego e da perda de autonomia pessoal. Na vida cotidiana os computadores promovem controle e vigilância da vida das pessoas, através de cartões bancários, cartões de saúde, cartões de crédito, de telefone celular, carteira de motorista, crediário, câmeras, ou seja, cada vez mais tecnologias. No entanto, nem todas as mudanças produzidas têm gerado benefícios. A sociedade da informação "envolve uma nova maneira de pensar e agir, porque a tecnologia é agora uma parte integrante da cultura” (LYON, 1998, p.62). 
Para Karl (1985), o sentido de moderno e de modernidade em qualquer época sempre é o de um processo de tornar-se novo e diferente, subverter o que é velho, tornar-se um agente de desordem. Assim, rompe com tradições e regras, que são substituídas por uma nova realidade relativa às rotinas da vida, ao trabalho e a seus regulamentos, sugerindo que repensemos questões relativas à autoridade e à identidade. Os modos convencionais de fazer as coisas são questionados e substituídos por novas formas baseadas na ciência, no crescimento econômico, na democracia ou na lei.

As inovações tecnológicas envolvem mudanças sociais profundas, movidas pelo capitalismo que busca constantemente novas mercadorias, novas fontes de força de trabalho, como novas tecnologias para suplementar ou substituir a força de trabalho, gerando maior produção, o que demanda um maior número de consumidores. As rotinas da vida diária alteram-se, quando não se precisa mais de relacionamentos face a face para se comunicar. As relações sociais se estendem no tempo e no espaço, podendo continuar sem interrupção. As mudanças tecnológicas demandam uma nova maneira de pensar e agir, pois a tecnologia se torna parte integrante da cultura, num ciclo de dependência. Usufruir a tecnologia de maneira crescente, estabelece o reconhecimento do fugaz, do transitório e do superficial. (LYON, 1998).

O ser humano encontra-se diante de um conjunto de mudanças sociais e culturais profundas que vêm acontecendo na sociedade, caracterizando a chamada pós-modernidade. As fronteiras perdem o sentido em um mundo globalizado e interligado pelos novos meios de comunicação, como a internet, em que as informações transitam com uma rapidez nunca vista na história da humanidade.

Tudo está englobado: uma mudança tecnológica acelerada, envolvendo as telecomunicações e o poder da informática, alterações nas relações políticas, e o surgimento de movimentos sociais, especialmente os relacionados com aspectos étnicos e raciais, ecológicos e de competição entre os sexos (LYON, 1998, p.7).

Nas últimas décadas, em decorrência do processo de globalização da economia, da cultura e da política, observa-se que o mundo do trabalho, no modo de produção capitalista, passa por metamorfoses em uma velocidade jamais observada na história da civilização. Tais mutações afetam diretamente a vida das pessoas independentemente da idade, da classe social, da cultura e dos valores. Notadamente afetam a vida de grupos de indivíduos, em particular os adolescentes, que se encontram na etapa do desenvolvimento humano na qual devem tomar decisões relativas aos estudos e/ou trabalho (MELO-SILVA; JACQUEMIN, 
2001). O complexo mundo das profissões acaba configurando-se em armadilhas para os jovens em busca de definição da carreira (WHITAKER, 1985) e da identidade profissional.

Para Drucker (2002), o trabalhador do conhecimento é diferente de qualquer trabalhador anterior, principalmente por dois aspectos: por ter posse dos seus conhecimentos e por provavelmente viver mais do que qualquer organização empregadora. A produção de idéias, informações e conceitos, ou seja, o recurso de possuir um determinado conhecimento é mais valorizado à medida que se torna mais especializado em uma determinada área e ocorre principalmente no trabalho intelectual.

O aumento de profissões relacionadas com a informação, nas quais o uso da tecnologia se torna instrumento de trabalho, traz benefícios no sentido de facilitar a execução, armazenamento, fluidez e rapidez no manuseio dos dados, das informações. Entretanto, as informações continuam não sendo distribuídas de forma eqüitativa. O desemprego está presente mesmo com o desenvolvimento econômico e crescimento de produtividade de muitos países (LYON, 1998). Por outro lado, cada vez mais o conhecimento pode representar um potencial, como sugere Drucker (2002), de significar conhecimento como utilidade, conhecimento como meio para obter melhores resultados sociais e econômicos.

Na pós-modernidade duas questões são cruciais: a proeminência das novas Tecnologias de Informação e Comunicação (TICs), facilitando extensões maiores da globalização; e o aumento do consumismo. O mercado de trabalho é diretamente afetado e sofre adaptações nesse novo cenário. O mundo está diferente para o adolescente que começa a vislumbrar uma profissão, como para todos os trabalhadores que vivenciam no processo de trabalho contemporâneo a necessidade de adaptações constantes.

A sociedade do século XXI afasta-se da Sociedade Industrial, na qual a comunicação simplesmente transmitia mensagens, descrevendo o mundo perfeitamente e predominando características como: segmentação, reducionismo, homogeneidade e linearidade. Para a Sociedade da Informação ou Sociedade do Conhecimento, em que se estabelece uma crescente complexidade, a comunicação associa-se à informação, unificação, visão global, relatividade do tempo e heterogeneidade, dentre outras questões que necessitam de contínua revisão.

[...] quanto mais somos envolvidos pelo mundo, mais difícil é para nós apreendê-lo. Na era das telecomunicações, da informação, da internet, estamos submersos na complexidade do mundo, as incontáveis informações sobre o mundo sufocam nossas possibilidades de inteligibilidade (MORIN, 2002, p.64). 
Para Pearce (1996), o mundo está diante de um novo paradigma, que consiste em uma nova maneira de pensar sobre nós, nossa relação mútua e a sociedade em que vivemos. O autor convida a todos a refletir sobre os tempos atuais, salientando que este novo paradigma não surgiu do nada, mas em resposta às circunstâncias que atualmente se vivem e às condições materiais do mundo contemporâneo. Um dos aspectos a ser considerado nesta nova era da comunicação é a linguagem que agora constrói o mundo e, não simplesmente, o representa. Novas formas de comunicação em um mundo conectado em redes de computadores levam indubitavelmente à necessidade de refletir sobre a internet, que representa uma das formas mais utilizadas para se vincularem as informações.

Uma das questões que deverá ser cada vez mais solicitada é como transformar tais informações em conhecimento não apenas em como acessar as informações. O conhecimento se constrói com base nas informações disponíveis e sujeito à qualidade disponível na internet. O único capaz de filtrar a qualidade de um texto, de um conceito, é o próprio usuário que busca a informação (REBOLLO, 2005).

A utilização dos computadores e a dependência cada vez maior da tecnologia traz impactos profundos na vida das pessoas, acarretando mudanças na forma de viver, trabalhar e comunicar. Considerando a importância desses assuntos para contexto da orientação de carreiras e com o intuito de explorar os benefícios e perigos desta nova tecnologia para a área de Orientação Profissional, a internet será abordada a seguir em sua utilização principalmente pelos adolescentes.

\subsection{Internet}

A fim de ampliar a compreensão e as possibilidades de utilização da internet é relevante começar por alguns dados históricos sobre esse tema. Na década de 1960, em decorrência dos receios oriundos da Guerra Fria o Departamento de Defesa dos Estados Unidos e a Advanced Research Projects Agency network (ARPAnet), agência da rede de projetos de pesquisa avançada, projetaram o computador com a finalidade de compartilhar informações, armazenar e proteger os dados de segurança nacional. O objetivo era desenvolver um sistema para operar em comunicação independente, uma questão de estratégia política diante dos receios de um ataque nuclear. Durante a década de 1980 outras redes apareceram com propósitos diferentes, a Computer and Science Network (CSnet) e a National Science Foundation Network (NSFnet), com o intuito de facilitar a comunicação do meio 
acadêmico, trocar informações, potencializar as pesquisas científicas (GORE; LEUWERKE, 2000).

Assim, a internet foi se desenvolvendo e atualmente se configura como uma cadeia de redes de computador de natureza e dimensões distintas que, interligados pelo mundo, promovem a troca de dados de modo dinâmico, ou seja, em tempo real. A partir desse grupo restrito de usuários a rede cresceu e ampliou a sua utilização, de maneira mais rápida do que qualquer outra forma de comunicação na história da humanidade. “A internet comercial comemora 10 anos e passou de poucos milhares para cerca de 32 milhões que fazem compras, vão ao banco, lêem jornais, namoram e se divertem no mundo virtual” (Folha de São Paulo, Folha Informática, 25/05/2005, p.1).

No Brasil, em 1990 o acesso à internet era dirigido pelo Ministério de Ciência e Tecnologia e gerenciado pelo Conselho Nacional de Desenvolvimento Científico e Tecnológico (CNPq), com o intuito de criar uma rede de serviços para a modernização do País. Mais tarde o controle foi transferido para o Ministério de Comunicação, gerenciado pela Empresa Brasileira de Telecomunicações (EMBRATEL). Em maio de 1995, o Brasil oficialmente entra na internet comercial.

A facilidade da utilização da internet tem dois aspectos principais. Um deles é o uso da rede de telefone disponível em todo o mundo com a utilização do Modulador e Demodulador (MODEM), equipamento que converte a informação digital do computador para ser transportada pela linha telefônica. O outro é o hipertexto que gerencia as informações, fazendo conexões com outros textos disponíveis na rede. Um outro importante fator de crescimento da internet foi possível pela implantação do “World Wide Web” (www), a chave da evolução e aplicação da Tecnologia de Informação e Comunicação (TIC) em escala mundial (TARGINO, 1997).

A internet e a www, rapidamente se tornaram indispensável parte da vida diária. Segundo Reile; Harris-Bowlsbey (2000) é importante saber que a internet é basicamente uma rede internacional de computadores e a www (web) é o seu conteúdo (textos, figuras, vídeos, áudio, dentre outros) acessado online. Assim, como sugerem os autores citados, mesmo que se tenha alguma distinção entre a internet e a www, tais conceitos são usados, no presente estudo, conforme citação dos autores e/ou como sinônimos.

Segundo Targino (1997), a internet, como um espaço democrático, pode trazer vantagens como: (a) organizar e disseminar grande quantidade de informação, em alta velocidade; (b) encorajar a cooperação em prol de aperfeiçoar os recursos humanos; (c) popularizar a informação; e (d) diminuir a estratificação social.“Entretanto, no Brasil, a 
presente democratização da informação e a menor desigualdade e estratificação social é mais aparente do que real” (TARGINO, 1997, p. 255).

Todo o potencial tecnológico disponível na atualidade é realidade para parte da população. Entretanto nas comunidades socioeconômicamente desprivilegiadas é preciso ampliar esse acesso a redes de transmissão de informação e de conhecimento. Apenas o acesso à informação, no entanto, não é o bastante se as pessoas ficarem à margem dos debates, por não terem aprendido a ler e a analisar criticamente os fatos, não entendendo o significado dos mesmos. Assim, a nova economia em nada irá se diferenciar da antiga se continuarem a exclusão, as imensas desigualdades sociais, as restrições sociais e políticas. Na ausência do conhecimento qualificado e acessível à ampla parcela da população, o mercado fica limitado pela baixa qualificação destes indivíduos (TARGINO, 1997).

A partir de um grande número de tecnologias disponíveis atualmente, a internet dispõe de programas de significativa utilização tanto para a pesquisa científica como para as intervenções no processo de escolha de carreira. Uma delas é o e-mail, que permite a comunicação entre as pessoas mundialmente, os usuários podem criar, editar, ler e enviar mensagens. Por meio da utilização do e-mail em projetos de pesquisa é possível compartilhar dados, documentos de forma facilitada. Nas intervenções os clientes podem acessar seus orientadores, sendo possível distribuir informações de forma rápida a um grande número de pessoas. O outro instrumento da internet, o www representa um forte instrumento para a Orientação Profissional tanto para pesquisa como para a intervenção, uma vez que alguns programas permitem a interatividade em tempo real. Há outras possibilidades de interatividade, como a reprodução de locais de trabalho e a simulação de situações com colegas, chefe, entre outras. A possibilidade de acessar filmes, mantendo a possibilidade de interatividade, possibilita a ampliação de sua utilização para além dos programas que podem aprofundar os detalhes das informações, à medida em que o usuário requer mais detalhes, personalizando os possíveis caminhos na busca dos dados (GORE; LEUWERKE, 2000).

Um outro aspecto que merece atenção é a questão ética do uso da informação, como a credibilidade e a qualidade das informações. A utilização da internet para inúmeros objetivos favoreceu o crescimento de abusos de todos os tipos como: romances, amizades, pornografia, grupos raciais, tráfico de drogas, invasão da privacidade. “Maior cuidado é necessário no caso do Brasil. A rápida expansão da internet, sem regras em um contexto marcado por profundas diferenças, onde a miséria convive lado a lado com a sofisticação tecnológica, pode influenciar grandemente os valores morais e éticos” (TARGINO, 1997, p. 256). 
O mundo se torna cada vez mais vulnerável e dependente dos serviços fornecidos pela internet. O caminho é criar estratégias para lidar com essa realidade mutante. Desta forma, torna-se necessário auxiliar o jovem que, se por um lado sabe lidar com a tecnologia, precisa aprender a interagir criticamente com toda a informação disponível, de modo a adquirir conhecimentos consistentes e desenvolvimento pessoal.

A internet cria novas necessidades, profissões são criadas, enquanto que outras desaparecem. Neste contexto as previsibilidades dos fatos vão diminuindo. Ao novo trabalhador não cabe mais encontrar o emprego que se encaixe a sua qualificação. O caminho a ser percorrido é ao contrário, ele deverá se adaptar com rapidez ao mercado. Para acompanhar esse movimento, o indivíduo deverá estar atento a suas múltiplas habilidades, ter disposição e a capacidade de aprender sempre. Pode-se concluir, então, que as novidades no mundo do trabalho vão além da utilização da internet e dos avanços tecnológicos, porque a prioridade é o conhecimento em sua utilização, sobretudo para o adolescente, população alvo deste estudo.

As mudanças na economia global, na força de trabalho, as exigências do mercado para novos profissionais, novas profissões tudo isso desafia cada vez mais os profissionais da educação, em especial os orientadores profissionais. Os orientados também são desafiados, sejam eles adolescentes ou adultos, a tomarem decisões em um cenário de velozes mudanças tecnológicas. A seguir serão consideradas a adolescência e a escolha da carreira.

\subsection{Adolescência e escolha da carreira}

A adolescência caracteriza-se como um processo evolutivo que compreende os aspectos bio-psico-social, é a transição do mundo infantil para o adulto. Entretanto, esse processo é vivido de maneiras diferentes dependendo da cultura e da sociedade na qual os jovens estão inseridos. Esse processo, bem como a forma em que é vivido na cultura ocidental, surgiu com a industrialização e o desenvolvimento da burguesia. Entretanto, em qualquer contexto sociocultural, esse período tende a ser vivido como um momento de crise e desequilíbrio, devido a todas as alterações fisiológicas e as repercussões psicológicas advindas das diversas mudanças para alcançar a vida adulta (LEVISKY, 1998). Cumpre destacar que, neste estudo, o adolescente em foco é aquele que aspira à carreira universitária.

Quanto mais complexa for a sociedade, principalmente no que se refere ao mundo do trabalho com as mudanças sociais e econômicas, citadas anteriormente, maiores serão as 
dificuldades dos jovens em realizar esse percurso, ocasionando muitas vezes um prolongamento desse processo de transição. Alguns fatores externos, como a prematuridade de efetuar a sua escolha profissional, na realidade brasileira (por volta de 16 anos) e, a pouca infra-estrutura de pessoal e de técnicas nas escolas dificultam o processo de escolha profissional. O jovem muitas vezes atravessa essa fase da vida sem nenhuma orientação e toma decisões de carreira sem a assistência e o acompanhamento de profissionais qualificados para facilitar o processo. Alguns adolescentes ingressam no mundo de trabalho de maneira precoce sem terem alcançado um nível de maturidade relativamente adequado para tomar decisões conscientes e autônomas. Por outro lado, há os cronologicamente adultos, que permanecem como adolescentes num estado de dependência afetiva e econômica (LEVISKY, 1998).

A adolescência sendo um período de transição da identidade infantil para a adulta tem o seu desenvolvimento psicológico marcado por um importante momento no qual a pessoa se redefine e vai buscando em si a consolidação de sua personalidade. O momento interno é de instabilidade, oscilação freqüente, em que tudo é redimensionado e questionado. Na adolescência há uma tendência dos jovens de se distanciarem dos pais, pelo processo de diferenciação, porém em alguns casos ocorre desvalorização e até agressão como resultado de resolução inadequada de conflitos entre as gerações. Para se auto-afirmarem, intensifica-se a valorização dos grupos de amigos, seus pares, com os quais se identificam, aplacam suas angústias e temores, e se fortalecem para boas e más ações. O grande desafio que o adolescente enfrenta é a construção da sua pessoa, da definição da identidade, sendo a conquista da identidade profissional questão primordial. O processo de aquisição da identidade, do conhecimento de si mesmo e da realidade desenvolve-se ao longo da vida, porém é na etapa de transição da infância para a idade adulta que se configura o conflito da juventude (BARDAGIR; HUTZ, 2006, LEVISKY, 1998).

Um dos comportamentos do jovem do mundo moderno e globalizado é o gosto pelo consumismo, o novo é mais atraente e facilmente substituído e descartado. Outras características são a impaciência, a pressa e o imediatismo. Não por acaso o passeio preferido são os "shoppings center” lugar de encontro; conversar, comprar, ir ao cinema e mais uma infinidade de possibilidades que trazem cada vez mais novidades. "As ferramentas e possibilidades trazidas pela tecnologia, assim como o consentimento familiar e social para novos comportamentos em relação ao outro e a si mesmo, trouxeram novas formas de viver, de comunicar-se e um novo tempo para vivê-las” (Dossiê Universo Jovem, 2005, p.59). 
Com o advento das tecnologias de informação, a internet, os vídeos, os CDs, DVDs e os aparelhos celulares, tornaram-se de uso maciço entre a maioria dos jovens que, de forma diferente dos seus pais, utilizam todos esses apetrechos com desenvoltura. Essa geração chamada Z, de Zapear, “[...] nasceu plugada nesse mundo globalizado. É impossível, para ela conceber um mundo sem computador, chats e telefones celular” (LEVENFUS, 2002, p.51). De acordo com o Dossiê Universo Jovem (2001), os nascidos na década de 1980 são da geração que nasceu plugada na internet e por isso vem sendo chamada de Geração Z, “zapear”. Os jovens dominam essas tecnologias com tal desenvoltura o que passa a impressão de estarem bem informados. Uma questão que educadores, pais e psicólogos colocam, referese à qualidade da informação acessada. O que esses jovens buscam na internet? Que tipo de informação ou comunicação? Qual a qualidade da informação procurada? Qual o nível de profundidade da comunicação?

Na educação o acesso à internet vem sendo ampliada, através de políticas públicas em educação que enfatizam a utilização em escolas, como uma forma de buscar uma maior implementação nos estudos. Entretanto, em uma pesquisa realizada recentemente Dwyer, et al (2007) verificaram que a utilização do computador, principalmente por estudantes mais carentes, piora o desempenho escolar. Os autores propõem que repensemos o papel do computador no ensino.

Em um outro estudo com 200 adolescentes, Henriques (2003) constatou que a principal utilidade da internet para os jovens é fazer e manter relacionamentos de amizade e depois pesquisas com trabalhos escolares. A internet é utilizada como entretenimento eletrônico para comunicar-se com os colegas sem sair de casa, com um vocabulário próprio presente na nova linguagem dos adolescentes. Outra pesquisa foi realizada pela MTV Brasil, Dossiê Universo Jovem de 2005, com objetivo de detectar tendências, entender comportamentos, apreender novos significados e traduzir em posturas as atitudes do jovem brasileiro e comparar com outro estudo realizado em 1999. Os resultados mostram que o índice total de posse de computador é de 46\%, mais que o dobro do registrado em 1999 que foi de $22 \%$, o acesso regular à internet foi de $15 \%$ para 66\%. Na classe A, 96\%, e na classe C, 53\% já mantém acesso regular à internet. A internet é acessada pela maioria dos jovens no cotidiano, e pode conectar as diferenças por meio de novas formas de linguagem. Os que questionavam um provável isolamento dos jovens na internet verificam ser esta uma nova forma de intensificar a comunicação entre os mesmos.

A forma de lidar com as informações encontradas é superficial, pois ao se depararem com dificuldades eles simplesmente mudam para outro site mais interessante e que lhes 
conceda uma informação de fácil entendimento e rápido acesso. A forma de lidar com a informação profissional não parece ser diferente, se quando acessam as informações não sabem o que fazer com elas, como utilizá-las em seu proveito para fazer a escolha da carreira, por exemplo.

As mudanças no cenário, a velocidade e volume da informação, a rapidez com que a tecnologia mudou o cotidiano, novos códigos e comportamentos, a sexualidade em experiências antecipadas, envolvem a todos com a sensação de que tudo está, de repente, ficando para trás, muito rápido (Dossiê Universo Jovem, 2005, p.19).

A comunicação dos jovens na Era da Tecnologia passa por uma releitura dos antigos significados e objetivos, se antes a comunicação podia ser facilmente interrompida, atualmente existem variedades para todos os estilos pessoais e momentos. “A linguagem entre os jovens definitivamente ganhou novas linguagens, canais alternativos específicos, e hoje é possível selecionar e usar o canal perfeito de acordo com o que se quer dizer, como se quer dizer, para quem se quer dizer e em que tempo se quer dizer” (Dossiê Universo Jovem, 2005, p. 26).

Nesse estudo foram citados os meios de comunicação mais comuns entre os adolescentes. O celular tido como básico para localizar e ser localizado, a mensagem curta de texto pelo celular que é utilizada quando há pressa e não se quer gastar dinheiro, o blog e fotolog que é um tipo de diário na internet onde expõem questões íntimas, o Orkut que é um espaço para reencontrar e conhecer pessoas onde cada um pode espiar a vida do outro, o Instant Messenger é um programa de conversa online, em tempo real com diversas pessoas e o e-mail que é o correio eletrônico de fácil acesso e normalmente de linguagem mais formal. Esses recursos são utilizados para permanecerem plugados nos amigos e atualizados nas informações, predominam a preocupação e a necessidade de encontrar o outro com facilidade de acesso. Os comportamentos de freqüente exposição da intimidade não parecem provocar incômodos, os relacionamentos de amizade, briga ou namoro são todos permeados pelas conversações na rede.

Os pais dos adolescentes, que normalmente seriam referência e respaldo para o jovem segundo o Dossiê Universo Jovem de 2005, cada vez mais valorizam a juventude. Parte dos adultos querem permanecer em um mundo eternamente jovem, no qual se posterga a inserção no mundo das responsabilidades e, por outro lado, paradoxalmente os jovens iniciam a vida adulta de modo precoce. “A identidade do mundo adulto está mudando, está perdendo 
contornos diante dos olhos de jovens que vêem pais e mães, estressados pelo trabalho, serem mais felizes quando se comportam como jovens” (Dossiê Universo Jovem, 2005, p.58).

$\mathrm{Na}$ adolescência o jovem, que já superou os obstáculos educacionais até o ensino médio e que aspira a uma carreira universitária, tem que escolher uma profissão e é nessa fase que a insegurança, os medos e a indefinição interferem na escolha profissional. $\mathrm{O}$ fato de estar envolvido com seus próprios sentimentos conflituosos, conhecendo pouco sobre si e seus interesses e aptidões, sobre as várias carreiras e as tendências do mercado de trabalho, dificulta a resolução e encaminhamento da decisão. Por vezes optam por decisões impulsivas, ou escolhas provisórias, como uma forma de minimizar as pressões da realidade do nosso sistema educacional.

Torna-se, portanto, fundamental orientar o adolescente nesse sentido, dandolhe possibilidades de se conhecer e de conhecer setores profissionais os mais diversos, para que possa vir a se definir de forma adequada ao conjunto de suas aptidões, necessidades e à realidade profissional, incluindo as condições de mercado de trabalho (LEVISKY, 1998, p.65).

Há de se considerar tendências e aptidões vocacionais e, além disso, atentar para as perspectivas futuras. Importa conhecer as transformações sociais do nosso tempo com o objetivo de auxiliar o jovem a realizar escolhas adequadas à realidade do mundo do trabalho atual e em suas projeções. O mundo do trabalho encontra-se em uma encruzilhada (WHITAKER, 1997), com subemprego, desemprego e emprego formal em declínio. Como “escolher” uma carreira neste cenário? Caberá às futuras gerações encontrar formas de adaptação ativa a essas mudanças e alternativas de trabalho e geração de renda (BRIDGES, 1997; CATTANI, 1996; FORRESTER, 1997; RIFIKIN, 1995).

Tantas alterações, indubitavelmente, afetam o processo de 'escolha' da carreira profissional. Analisar os determinantes que influenciam a escolha sempre foi objeto de preocupação da Orientação Vocacional / Profissional e, atualmente, cumpre destacar, também, a necessidade de dar atenção maior à velocidade das mudanças. Significa pensar a questão trabalho, enquanto atividade neste contexto e nos novos papéis exigidos do governo, do empresariado e dos trabalhadores (MELO-SILVA; JACQUEMIN, 2001, p. 28).

Os familiares desses adolescentes fizeram suas "escolhas” profissionais em décadas anteriores, nas quais um diploma universitário era suficiente para abrir as portas do mercado de trabalho (MELO-SILVA; JACQUEMIN, 2001). Mais recentemente as incertezas aumentaram a tal ponto que os pais e educadores, também, encontram dificuldades para 
orientar a geração mais jovem. É sabido que os pais, explicitamente ou implicitamente, influenciam seus filhos (ALMEIDA; MELO-SILVA, 2007).

Segundo Bardagi e Hutz (2006) a influência da família na escolha profissional dos filhos é salientada pelas teorias do desenvolvimento e tem um caráter fundamental, entretanto a natureza dessa influência permanece como um campo a ser investigado por pesquisadores. O momento da escolha profissional é vivido normalmente com dificuldades pelo adolescente, importando incluir a participação dos pais tanto dentro de casa através do diálogo como nos diversos serviços oferecidos. Nessa pesquisa os autores relatam que a dificuldade em realizar a escolha profissional prejudica o bem estar. Os adolescentes mais indecisos são conseqüentemente mais deprimidos e ansiosos enquanto que a menor indecisão na escolha promove escolhas confiáveis e congruentes com seus interesses.

A participação dos pais no desenvolvimento de carreira de seus filhos foi salientada por achados de um estudo conduzido por Trusty (1996). Destaca a importância do envolvimento dos pais no processo de escolha e desenvolvimento da carreira de seus filhos como um orientador significante das atitudes construtivas e percepções positivas do futuro para os adolescentes. Registra-se também a necessidade dos orientadores estarem atualizados em seu conhecimento sobre informação na carreira porque os pais esperam que os mesmos sejam a fonte primária de informação, nesse sentido, para seus filhos. Esses pais percebem os “conselheiros da escola” como fonte primária de informação ocupacional, talvez parcialmente porque eles mesmos freqüentemente carecem de experiências e conhecimentos adequados para oferecer a seus filhos. O desafio dos educadores, orientadores profissionais, psicólogos e todos aqueles que lidam com adolescentes, é auxiliá-los na compreensão desse novo mundo virtual e real, de uma maneira integrada psicologicamente e madura.

Nesse momento de queixas incontáveis, de sentimentos de timidez e de proporcional consumo de álcool; de tanta informação sobre sexo e de tão pouco uso da camisinha; de drogas cada vez mais fortes, mais baratas e acessíveis; de torres que desmoronam junto com os projetos de futuro, fica claro que estar bem informado sobre profissões, sexo e drogas não resolve em quase nada a vida de quem ainda não amadureceu. É preciso que aprendam a selecionar criticamente as informações e transitem com calma por esse mundo hiperveloz (LEVENFUS, 2002, p.52).

Em se tratando de adolescentes que procuram atendimento em Orientação Profissional, cabe indagar se os mesmos utilizam o tempo na internet acessando informações sobre profissões, carreiras e universidades. Os meios de comunicação, estão repletos de informação desta natureza, entretanto, na prática clínica da autora desta pesquisa com os 
adolescentes em Orientação Profissional, os mesmos relatam que utilizam pouco, talvez de maneira inadequada e/ou insuficiente, as tecnologias de informação disponíveis. Observa-se que há informações sobre profissões e carreiras (universitárias, tecnológicas e técnicas) disponíveis na internet, embora de qualidade questionável, cumprindo verificar se o jovem sabe como lidar com estas informações. Além disso, a variedade de carreiras em constante processo de construção-desconstrução elimina, transforma e gera novas profissões, instalando incertezas em relação ao futuro.

O adolescente do universo deste estudo corresponde a uma parcela pequena da população brasileira que tem acesso ao Ensino Superior. É o jovem que tem a possibilidade de efetuar uma escolha profissional, da região urbana, de classe média e média alta, aluno de escola particular (predominantemente) ou pública, com acesso mais facilitado às inovações tecnológicas como celulares e internet. Tal população objetiva inserir-se no mundo do trabalho como profissional de nível superior.

Por questões históricas de exclusão econômica, social e educacional, uma parcela significativa dos jovens, entre 17 e 24 anos, não busca carreira universitária e ingressa precocemente no mercado de trabalho. As problemáticas educacionais e profissionais deste contingente populacional requerem atenção e constituem objetos de outros estudos. Entre eles, registram-se os estudos sobre as possibilidades alternativas, mais democráticas, de acesso ao ensino superior, como as investigações sobre os programas de cotas universitárias, o Programa Universidade para todos (ProUni) e políticas públicas. A despeito da relevância de estudos no contexto referido, este estudo focaliza os procedimentos de intervenção destinados a jovens que buscam serviços de orientação profissional, objetivando contribuir com a produção do conhecimento sobre processo e resultados.

Para trabalhar com os adolescentes e observar de uma forma mais ampla a forma como se relacionam entre si, as trocas de informações, a forma de utilizar seus recursos pessoais e tecnológicos, optou-se pelos grupos, porque representam um espaço que facilita a comunicação e a aprendizagem entre eles. Para Levisky (1998), o adolescente se sente só, distante de seus pais, de seu modo de ser infantil e, ainda, em processo de construção de uma nova identidade. O grupo, nessas circunstâncias, funciona como protetor e assegurador ante as suas angústias e temores. 


\subsection{Orientação Profissional em processos grupais na perspectiva da Teoria de Grupo Operativo}

Para a compreensão desse adolescente que tem a sua disposição, amplos e variados recursos da tecnologia para a busca de informação profissional, considerou-se apropriado analisar um procedimento de intervenção em Orientação Profissional realizado em processos grupais presenciais. A seguir algumas vantagens serão abordadas para justificar tal escolha.

No grupo presencial de Orientação Profissional, os integrantes trocam informações, relatam experiências e, assim, um pode contribuir com o outro. Além disso, na situação grupal é possível utilizar técnicas dramáticas e expressivas, facilitadoras para os adolescentes, pois favorecem o compartilhamento de sentimentos, problemas e vivências semelhantes entre eles, enriquecendo a sua gama de possibilidades reflexivas. Para Carvalho (1995), o atendimento em grupo traz vantagens extremamente relevantes "uma vez que a participação grupal leva a experiências profundas de autoconhecimento, conhecimento do outro e interação” (CARVALHO, 1995, p.81).

Outro ponto importante da intervenção em grupo, como ressalta Melo-Silva e Jacquemin (2001) é que o grupo propicia o convívio habitual do adolescente em turmas e o papel facilitador desempenhado pelos demais integrantes de um grupo. Destacam os autores que há:

[...] necessidade de serem desenvolvidas formas alternativas de ampliação do atendimento na modalidade grupal, visando o acesso a um número cada vez maior de jovens à Orientação Vocacional / Profissional. Além das vantagens apontadas, os atendimentos em grupo ampliam o alcance dos serviços, possibilitam a relevância social do serviço prestado à comunidade (MELOSILVA; JACQUEMIN, 2001, p. 85).

Para Niles e Harris-Bowlsbey (2005), as pesquisas em sua maioria concordam que existem algumas vantagens nas experiências de Orientação Profissional em grupo. Primeiro pela orientação em grupo se mostrar eficiente em alcançar seus objetivos, ela maximiza o tempo do orientador por atender um maior número de clientes. E o mais importante é que nesse tipo de intervenção os integrantes do grupo têm a oportunidade de aprender novas informações na troca entre eles, recebem suporte social e emocional dos demais integrantes e aprendem a compartilhar as experiências similares. As intervenções em grupo oferecem a oportunidade para os integrantes de dividir as pesquisas realizadas e as idéias de cada um, podendo maximizar as oportunidades para aprender novas estratégias. 
As trocas de experiências em grupo na Orientação Profissional aumentam quando o orientador tem a habilidade de fomentar a cooperação e o sentimento de inclusão grupal no qual os integrantes podem focalizar objetivos comuns. Para tanto é fundamental que o grupo possa se vincular, estabelecendo interações além de desenvolver um conhecimento interpessoal. Na medida em que tem o mesmo objetivo, a escolha da profissão, o grupo pode se fortalecer ao compartilhar as angústias e dúvidas vivenciadas no processo.

Na presente investigação, o referencial teórico que fundamenta a intervenção de Orientação Profissional, foco deste estudo, é a análise do processo grupal que se fundamenta na abordagem de Grupo Operativo de Enrique Pichon-Rivière $(1994,1995)$. Esse referencial compreende o homem como um ser de necessidades, inserido em uma sociedade e em uma relação dialética com o mundo. "Entendo o homem como se configurando em uma atividade transformadora em uma relação dialética mutuamente modificante com o mundo, relação esta que tem seu motor na necessidade” (QUIROGA, 1994, p.69).

A proposta de “aprender a pensar" em um diálogo, elaborando obstáculos, resolvendo tramas internas, resolvendo medos, aprendendo a pensar em grupo e a conviver com ele de maneira harmoniosa e em busca da criatividade grupal, consiste em ver os distintos aspectos de um problema, de diferentes perspectivas, de uma maneira dialética, que permite a compreensão dos pares contraditórios, e não dilemática (o que obstaculiza o processo). Nesse sentido, para se estudar a contribuição da informação nas escolhas profissionais de adolescentes, parece adequada a abordagem de Grupo Operativo, por promover uma adaptação ativa à realidade, proposta por Pichon-Rivière, potencializando as comunicações (trocas) entre os adolescentes em um contexto sócio-histórico determinado, mutuamente modificante e criativo.

A técnica de Grupo Operativo foi elaborada por Pichon-Rivière a partir da sua prática profissional em Hospitais Psiquiátricos, na cidade de Rosário, Argentina, nos anos 50 do século passado. O Grupo Operativo de Enrique Pichon-Rivière fundamenta-se na Psicologia Social. Esse referencial se apóia em uma concepção de sujeito, entendido como o emergente de uma complexa rede de vínculos e relações sociais. O sujeito é social e historicamente produzido em constante dialética com o ambiente em que vive, ou seja, constrói o mundo e nele se constrói. Para Pichon-Rivière, um grupo pode ser compreendido como:

Um conjunto restrito de pessoas, ligadas por constantes de tempo e espaço, articuladas pela mútua representação interna, que se propõe, de forma explícita e implícita, uma tarefa, que constitui sua finalidade, interatuando através de complexos mecanismos de assunção e atribuição de papéis (QUIROGA, 1994, p. 78). 
Cada indivíduo se encontra com o outro e, nessa concepção de grupo, o vínculo não se esgota em uma experiência externa, mas na possibilidade de interiorização desta relação, uma internalização recíproca. Ao permanecerem em comunicação, os sujeitos do grupo estabelecem vínculo, constroem a trama das relações, o que Pichon-Riviére denomina de mútua representação interna, ou seja, ocorre o processo de internalização recíproca, com a conseqüente transformação dos sujeitos implicados. Nessa abordagem o grupo é centrado na tarefa, toma como problemática central as relações entre os integrantes para a realização da tarefa. Focaliza-se no modo como os indivíduos se organizam e interagem, como se relacionam com os objetivos propostos, com a finalidade de aprender a pensar. As concepções teóricas que fundamentam a abordagem de Pichon-Rivière são organizadas em um modelo denominado de Esquema Conceitual Referencial Operativo (ECRO). Ele permite a compreensão do sistema social e do sujeito inserido na sociedade. Por essa razão esse referencial foi considerado apropriado para este estudo, tanto para subsidiar a intervenção quanto para nortear a análise dos dados relativos ao processo grupal.

Muitas vezes, durante o processo grupal os integrantes se deparam com dificuldades, ansiedades ou angústias que são vivenciadas no grupo. O processo em Grupo Operativo tem como eixo uma tarefa ou várias que visam a finalidade da constituição do grupo. Na realização da tarefa o grupo trabalha, explicitamente com os objetivos para a sua constituição e, implicitamente, os conteúdos que emergem em decorrência das dificuldades.

O processo de estruturação do grupo se faz através da interpretação do caráter implícito do ato de assumir e atribuir papéis, que aparecem no grupo como uma forma de manejar as ansiedades e os medos básicos presentes na nova situação grupal. O grupo distribui funções que têm como objetivo a produção grupal, sua coesão e sua manutenção. Estes papéis são vivenciados em duas dimensões: implícita e explícita.

O Grupo Operativo no contexto atual pode ser utilizado como uma tecnologia no sentido de poder desenvolver no grupo a gestão do conhecimento do pensamento crítico, no qual “as intervenções grupais possuem um caráter potencializador, cooperativo e oportuno quanto à possibilidade de gerir um novo conhecimento, isto é, pensar em recursos e instrumentos potencializadores de mudanças, ante a dura realidade do tempo presente” (CIAMPONE, 2000).

O grupo de Orientação Profissional pode favorecer ou potencializar o desenvolvimento no adolescente de uma prontidão para receber as informações profissionais e utilizá-las como ferramentas na escolha da profissão. Para Sampson e Lumsden (2000), as pessoas são diferentes na prontidão para a escolha de carreira, e eles precisam de diferentes 
tipos de intervenção baseados no grau de prontidão para o processo de escolha de profissão. Os indivíduos com um alto grau de prontidão para a decisão profissional são beneficiados pelas intervenções tipo auto-ajuda (programas na intenet, leitura de guias, conversas com profissionais, dentre outros). Enquanto que aqueles com baixa prontidão têm maiores dificuldades e precisam ser auxiliados, apresentam ansiedade elevada para a escolha profissional, instabilidade na perseverança de suas escolhas e expectativas negativas.

A maturidade para a escolha da profissão, de acordo com Niles e Harris-Bowsbey (2005), representaria a capacidade de enfrentar as exigências tanto sociais como pessoais, e de integrar dentro de si a escolha de um papel profissional e pessoal dentre os vários possíveis. Assim sendo, refletir sobre a prontidão dos adolescentes para a escolha da profissão, principalmente com a possibilidade cada vez maior de se ter acesso a informações sem a intervenção de um orientador profissional, parece instrumental, neste estudo, buscar nas Teorias do Desenvolvimento de Carreira o conceito de maturidade desenvolvido por Super.

\subsection{A Maturidade para a escolha profissional na perspectiva da Teoria Desenvolvimentista.}

Quem procura informação profissional? Como procura? E qual a qualidade da busca de informações? Há relação com o nível de maturidade? Tentando encontrar respostas, este estudo focalizará a maturidade como uma forma de potencializar o desenvolvimento do adolescente na busca qualificada da informação. Apenas a informação não é bastante para a escolha vocacional, se não existe um amadurecimento no adolescente. Jepsen ${ }^{2}$ (1975 apud TAVEIRA, 2000, p.169), observava que “a procura de informação sobre as escolhas profissionais era um bom preditor de sentimentos de confiança e de certeza relacionados com as escolhas profissionais”. A informação profissional torna-se cada vez mais relevante, na atualidade, considerando o advento da comunicação digital. Se por um lado, a maturidade favorece na prontidão para o adolescente lidar com a escolha da profissão, a informação por outro lado pode facilitar e alicerçar a escolha da profissão. Buscar informação significa explorar o mundo do trabalho, as carreiras, as grades curriculares, e tomar decisões ou até fazer escolhas provisórias.

\footnotetext{
2 JEPSEN, D.A. Occupational decision development over the high school years. Journal of Vocational Behavior, 7, 225-237, 1975.
} 
Ficou demonstrado que a exploração vocacional se relacionava positivamente com o desenvolvimento das seguintes dimensões de maturidade vocacional: tomada de consciência dos fatores curriculares e da escolha profissional, consciência dos valores e dos interesses pessoais, verbalização de pontos fortes e fracos, acuidade das auto-avaliações e independência da escolha vocacional (TAVEIRA, 2000, p.169).

Até meados do século passado concebia-se a escolha profissional como um momento único e estático na vida do indivíduo, que tinha a tarefa de emparelhar suas características com as da ocupação (BALBINOTTI, 2003). A base eram as teorias denominadas psicométricas ou traços-e-fatores. Nesta fase a ênfase era dada no conteúdo das decisões vocacionais e não ao processo de tomada de decisão. Assim, o problema da escolha profissional seria solucionado a partir do momento em que o indivíduo obtivesse conhecimento sobre si e o meio. O conhecimento era concebido como uma simples aquisição racional de informações (TAVEIRA, 2000).

Posteriormente outras concepções foram desenvolvidas, alterando a ênfase dos estudos, que ao invés de se preocuparem com as ocupações passaram a centrar a atenção nos processos de desenvolvimento das carreiras. Passa-se então, a conceituar a escolha da carreira e a adaptação profissional como um processo contínuo que tem lugar desde o nascimento e se prolonga por toda a vida (BALBINOTTI, 2003, PATTON; LOKAN, 2001, PIMENTA, 1981, SILVA, 2004, TAVEIRA, 2000).

Por contraste, nos novos modelos, considera-se a possibilidade de
construção, de realização e de desenvolvimento da pessoa e a função da
orientação passa a ser, facilitar a realização do indivíduo. Neste sentido,
passa a valorizar-se tanto as dimensões psicológicas como as dimensões
mais pedagógicas do processo de intervenção vocacional (TAVEIRA, 2000,
p.20).

Em um estudo de revisão sobre a fundamentação teórica do construto de maturidade para a escolha profissional, destaca-se que o mesmo fez sua "entrada no corpo teórico da Psicologia Vocacional na segunda metade do século passado” (SILVA, 2004, p.266). A primeira formulação teórica aparece na década de cinqüenta, do século passado, no âmbito das abordagens desenvolvimentistas do comportamento vocacional como apontam Ginzberg, Ginsburg, Axelrad; Herma, Super (SILVA, 2004). Ao longo dos anos foram realizadas revisões importantes na avaliação da maturidade para a escolha profissional, citadas por Silva (2004). A primeira delas foi realizada por Super em 1974, que ofereceu uma crítica científica e técnica a respeito do construto. Na década de oitenta, ainda segundo a referida revisão, os trabalhos de Westbrook e de Betz contribuíram para o desenvolvimento do construto e, mais 
recentemente, Betz e Savickas constituem importantes fontes de referência sobre maturidade para escolha da carreira. Kapes; Whitfield e de Walsh; Betz contribuem com revisões mais sintéticas sobre testes e instrumentos de avaliação psicológica. Assim, o conceito de maturidade para a escolha profissional nos adolescentes emerge em um contexto de desenvolvimento de teorias evolutivas que consideram as várias mudanças da pessoa ao longo da vida (SILVA, 2004).

Ao longo da sua existência, as pessoas deparam-se com determinadas tarefas ou expectativas, que têm a sua origem na sociedade e cultura onde os indivíduos se integram, e utilizam os seus recursos comportamentais (career coping behaviors), procurando lidar com elas de uma forma eficaz. O grau de sucesso com que respondem a estas expectativas sociais indica o seu nível de maturidade da carreira (SILVA, 2004, p.268).

Segundo Silva (2004), a formulação inicial de Super em 1955 foi fortemente apoiada nas concepções de Bühler (estádios de desenvolvimento) e de Havighurst (tarefas de desenvolvimento), o desenvolvimento profissional pode ser dividido em etapas da vida em se considerando o desenvolvimento individual. A escolha profissional seria o resultado de uma série de decisões que durariam por toda a vida. A idéia contrastava totalmente com a vigente até então, a teoria dos traços e fatores de Parsons (1909).

A teoria de Super conceitua o desenvolvimento de carreira através da vida (life span), apresentando as variações individuais e situacionais que influenciam de modo determinante o desenvolvimento de carreira. Os indivíduos normalmente se localizam em um contexto de múltiplos papéis em articulação na vida. Essa teoria ajuda a pessoa a clarificar, articular e implementar seus papéis de vida, ou seja, pode visualizar os processos de desenvolvimento de carreira e promover as implementações necessárias (NILES; HARRIS-BOWLSBEY, 2005).

Por mais de 40 anos Super e seus colaboradores elaboraram e refinaram uma teoria, que segundo ele mesmo é uma teoria segmentada. Nela três aspectos do desenvolvimento são centrais na carreira: ao longo da vida (life-span), um espaço na vida (life-space) e os conceitos de si ou autoconceito (self-concept). $\mathrm{O}$ auge da teoria se deu através do modelo de intervenção classificado de Modelo de Avaliação e Orientação de Carreira (C-DAC), nele os três segmentos da teoria (life-span, life-space e o self-concept) foram colocados em prática a fim de auxiliar as pessoas a articularem suas dúvidas de carreira, examinarem a saliência de seus papeis na vida e clarificarem seu autoconceito. Foram propostas, 14 suposições (NILES; HARRIS-BOWLSBEY, 2005). 
As 14 suposições segundo Guichard e Huteau (2001) resumem a teoria de Super e serão citadas a seguir:

1- As pessoas são diferentes em suas aptidões, personalidades, necessidades, valores, interesses, traços e no autoconceito.

2- As pessoas são qualificadas, dependendo de suas características pessoais para uma variedade de ocupações.

3- Cada ocupação demanda características que combinem com as habilidades e com os traços de personalidade, com uma margem de tolerância suficiente que permita uma variedade de ocupações para cada indivíduo e vice-versa.

4- As preferências e as competências vocacionais, as situações nas quais as pessoas vivem e trabalham e seu autoconceito mudam com o tempo e experiência.

5- O processo de mudança ocorre em uma série de estágios da vida, caracterizado por uma seqüência de crescimento, exploração, estabelecimento, manutenção e declínio. Um pequeno ciclo se estabelece na transição de um estágio para o próximo ou cada vez que um indivíduo se desestabiliza, ocorrem mudanças no tipo de necessidades, doença, prejuízo, ou outros eventos pessoais e socioeconômicos. Estas instabilidades ou múltiplas provas de carreira envolvem novos crescimentos, reexploração e restabelecimento.

6- A natureza do modelo de carreira de uma pessoa é determinada pelo nível ocupacional atingido, nível socioeconômico dos pais, suas aptidões mentais, educação, habilidades, características pessoais, oportunidades que lhe são oferecidas e pela sua maturidade de carreira.

7- A maturidade de carreira compreende as condições de perceber as demandas do ambiente em que está inserido, bem como, da prontidão do indivíduo em corresponder a estas demandas.

8- A maturidade de carreira vai se constituindo ao longo das etapas da vida, através do desenvolvimento de atitudes próprias da etapa de vida e da idade cronológica. Por outro lado, para enfrentar essas tarefas são necessários recursos cognitivos e afetivos que definem a prontidão do ponto de vista psicológico para responder a essas demandas.

9- O desenvolvimento da carreira pode ser incrementado em parte ao facilitar a maturação das habilidades e interesses e em parte para desenvolver o autoconceito.

10- O desenvolvimento de carreira é principalmente o desenvolvimento e a implementação ocupacional do autoconceito. Assim, o autoconceito é a síntese de várias condições internas como: aptidões herdadas, experiências, oportunidades em observar e 
desempenhar diferentes papéis, além da avaliação dos outros sobre a capacidade em desempenhar tais papéis.

11- O processo de síntese ou compromisso entre fatores individuais e sociais, entre o autoconceito e a realidade, é um dos papéis representados e aprendidos pelo feedback. Mesmo sendo esses papéis representados em fantasia ou vividos em uma atividade real.

12- A satisfação no trabalho e na vida depende de quanto o indivíduo pode realizar as suas capacidades, necessidades, valores, interesses, personalidade e autoconceito. A satisfação depende do estabelecimento num tipo de trabalho, numa situação profissional e num modo de vida correspondentes aos papéis que ele descobriu serem convenientes durante as etapas de crescimento e de exploração.

13- O grau de satisfação que as pessoas obtêm no trabalho é proporcional ao grau de habilidade em implementar o autoconceito.

14- O trabalho e a ocupação promovem um foco para a organização da personalidade para a maioria de homens e mulheres. Algumas vezes outros papéis são centrais dependendo das tradições sociais, da estrutura da oferta num dado momento e das suas preferências e capacidades (GUICHARD; HUTEAU, 2001).

Essas proposições de Super em um contexto histórico tiveram a amplitude de mudança de paradigma no campo da Orientação Profissional que, tendo sido focado na vocação, passa a priorizar a carreira; e também, os que priorizavam apenas a escolha da carreira passam ao amplo processo do desenvolvimento de uma carreira no percurso ao longo da vida (life-span) (NILES; HARRIS-BOWLSBEY, 2005). Segundo Savickas (2001), Super levou os orientadores profissionais a expandirem os estudos de como se escolhe uma profissão simplesmente, para como as pessoas desenvolvem suas carreiras ao longo da vida. E assim, ocorre uma mudança de pensamento de como os diferentes indivíduos se encaixam nas diversas ocupações, para como os indivíduos desenvolvem seus papéis profissionais ao longo da vida.

O desenvolvimento de carreira, inserido em um processo ao longo da vida (life-span), depende de um conjunto de fatores, como: o nível socioeconômico, as aptidões mentais, a educação, as habilidades, as características pessoais e as oportunidades que lhe oferecem. $\mathrm{Na}$ adolescência começa a ser esperada uma prontidão para realizar a escolha de carreira, ou seja, uma maturidade para a escolha profissional. O que denota a capacidade de enfrentar as exigências sociais como as pessoais e de integrar a escolha de um papel vocacional e pessoal dentre os vários possíveis (NILES; HARRIS-BOWLSBEY, 2005). 
Para Super, a carreira se desenvolve ao longo do curso da vida e através de uma série de etapas do desenvolvimento as pessoas podem encontrar o que almejam. Para tanto, identificou uma série de etapas correspondentes às idades da vida: o crescimento (infância - 4 até 13 anos), a exploração (adolescência - 14 aos 24 anos), o estabelecimento (jovem adulto 24 aos 44 anos), a manutenção (adulto - 44 aos 65 anos) e o descompromisso (velhice - 65 em diante) (NILES; HARRIS-BOWLSBEY, 2005).

A etapa do crescimento compreende interrogar-se sobre o futuro, aumentar o controle sobre a própria vida, convencer-se da importância do sucesso escolar e profissional, adquirir boas atitudes e hábitos de trabalho. A etapa exploração se caracteriza pelas tarefas de cristalização, especificação e implementação de uma escolha profissional. Nessa etapa o jovem imagina um futuro, uma profissão, até se cristalizarem numa identidade vocacional reconhecida. Para a realização da tarefa de especificar uma escolha é necessária uma exploração das profissões, ou seja, buscar por informações acerca das profissões que despertam interesse (GUICHARD; HUTEAU, 2001).

O presente estudo está circunscrito à etapa da exploração, adolescência, fase em que é fundamental a busca de informações profissionais para implementar a sua escolha de carreira. Assim, como sugere Taveira (2000):

[...] o significado da expressão "informação profissional” altera-se e passa a designar muitas das vezes o tipo de conteúdos envolvidos nos processos de exploração e de tomada de decisão. Por sua vez, escolhe-se o termo "exploração" para denominar os processos de procura, de interpretação e de integração de informação (pessoal e do mundo profissional) na resolução de problemas ou dilemas vocacionais (TAVEIRA, 2000).

Segundo Savickas (2001), o jovem está pronto ou maduro para efetuar sua escolha profissional quando tem um vasto conhecimento baseado em informações e uma ampla exploração que suportem sua escolha. Neste momento os testes e os inventários fazem sentido ao jovem, pois ele conhece sobre o mundo profissional e sabe como fazer suas escolhas profissionais.

Segundo Lobato e Koller (2003), mesmo que o desenvolvimento vocacional seja aqui definido em termos cronológicos, o mesmo não pode ser compreendido como amadurecimento físico. As autoras ressaltam o exposto a seguir.

A maturidade para a escolha profissional não se acha, na verdade, vinculada à idade, mas à necessidade de tomar um determinado tipo de decisão. Para fazer uma escolha profissional aproximada aos interesses e 
ao seu nível de escolaridade, o indivíduo deve ter acumulado informações relativas ao seu meio e a si mesmo para, depois, elaborar uma representação organizada das ocupações e de si próprio (LOBATO; KOLLER, 2003, p.59).

A teoria do espaço no curso da vida (life-space) é representada sob a forma do gráfico do Arco-Íris (life-career rainbow) da vida pessoal e profissional. Neste esquema há a tentativa de integrar o desenvolvimento do indivíduo ao longo de toda a vida e a articulação dos seus diferentes papéis sociais. As pessoas tendem a desempenhar nove papéis basicamente em suas vidas. Os papéis cronologicamente aparecem assim: primeiro o de filho(a), o segundo de estudante, o terceiro de homem ou mulher, o quarto de cidadão, o quinto de trabalhador, o sexto de cônjuge, o sétimo dedicado ao lar/ família, o oitavo pai ou mãe e o nono e último de aposentado. Estes são papéis desempenhados em lugares específicos, como: casa, escola, local de trabalho e na comunidade (NILES; HARRIS-BOWLSBEY, 2005).

Os vários conceitos foram desenvolvidos durante as inúmeras pesquisas realizadas por Super e seus colaboradores. Nos trabalhos mais recentes, Super em 1990 define a maturidade para a escolha profissional como:

[...] a capacidade do indivíduo para enfrentar as tarefas de desenvolvimento com as quais ele é confrontado como conseqüência de seu desenvolvimento social biológico, de uma parte, e das necessidades da sociedade em relação às outras pessoas que alcançam este estado de desenvolvimento, de outra parte (BALBINOTTI, 2003, p. 463).

Houve uma redefinição do conceito de maturidade para a escolha profissional, que aparece com Super no contexto evolutivo de desenvolvimento. Para chegarmos a uma adequação para os dias de hoje, Silva (2004) afirma o seguinte, com base em Savickas:

[...] o conceito de maturidade da carreira, para que continue a ser viável na investigação e na intervenção vocacional dos nossos dias, deve ter uma aplicação mais limitada do que a que the foi inicialmente outorgada, precisando ser entendido, especificamente, 'como o grau de preparação dos sujeitos para realizarem decisões de carreira’ (SILVA, 2004, p. 271).

Essa restrição no conceito de maturidade profissional, se por um lado inviabilizou os projetos iniciais de Super, que pretendia elevar o conceito de maturidade de carreira como indicador do grau de desenvolvimento vocacional ao longo de toda a vida, por outro lado, como opina Silva (2004), o conceito ganha uma maior exatidão e clarificação ao se restringir sua abrangência ao campo das decisões de carreira.

Um importante teórico da linha desenvolvimentista foi John Crites, como aluno de Super teve a oportunidade de aprofundar e aperfeiçoar a proposta inicial acerca da maturidade 
para a escolha profissional. Ele propõe que a maturidade para a escolha profissional seja considerada como um fator geral, composto por diferentes dimensões: consistência, realismo, competência e atitude. As duas primeiras se referem ao conteúdo da escolha e as duas últimas ao processo. Crites focalizou seu trabalho no estudo dos processos de escolha (NEIVA, 1999; SILVA, 2004).

Dentro do construto de maturidade para a escolha profissional existem dois modelos estruturais, um é o modelo da maturidade de carreira de Donald Super e o segundo é o modelo hierárquico da maturidade de carreira de John Crites. O primeiro modelo desenvolvido por Super fazia uma reflexão teórica do estudo longitudinal do desenvolvimento vocacional, denominado de Career Pattern Study (CPS), desenvolvido por: Super, Crites, Hummel, Moser, Overstreet; Warnath em 1957, que compreende a maturidade para a escolha da carreira em cinco dimensões principais: orientação para a escolha vocacional, informação e planejamento da profissão, consistência das preferências vocacionais, cristalização dos traços e sensatez das preferências vocacionais. Na década de 1980, com um modelo básico da maturidade de carreira, começa a aprimorar e então integrar cinco dimensões: planificação, exploração, informação, tomada de decisão e orientação para a realidade. Estas dimensões fazem parte dos resultados da investigação longitudinal com os participantes do CPS. As primeiras quatro dimensões são avaliadas através do instrumento desenvolvido por Super, o Career Development Inventory (CDI) (SILVA, 2004).

O segundo modelo, desenvolvido por Crites, origina-se no mesmo estudo longitudinal do CPS, entretanto com diferentes contribuições. Ele sugere que a maturidade para a escolha da carreira deva ser medida de maneira mais adequada se incluirmos os comportamentos e as tarefas de desenvolvimento. Para tanto, propõe um modelo hierárquico e multidimensional da maturidade de carreira, inspirado no modelo da inteligência de Vernon realizado em 1950. Nesse modelo apresenta três níveis hierarquicamente inter-relacionados: no nível de base estão os comportamentos de carreira que deverão revelar mudanças com a idade; no nível intermediário estabelece uma distinção entre conteúdos e processos da escolha de carreira que correspondem às competências e às atitudes da escolha e no nível mais geral da hierarquia fica o grau de desenvolvimento de carreira. A fim de avaliar as dimensões do seu modelo (atitudes e competências), desenvolveu a primeira medida estandardizada e objetiva da maturidade de carreira, o Career Maturity Inventory (CMI) (SILVA, 2004).

A exata natureza do construto de maturidade da carreira é um problema, não há consenso e posições universalmente aceitas. Existem duas dimensões da maturidade da carreira, a dimensão afetiva (atitudes) e a cognitiva (competências). Alguns autores 
acrescentam a dimensão comportamental. A validade e viabilidade do construto permanecem insuficientemente estudadas e as conseqüências comportamentais da maturidade da carreira, ou seja, seus resultados e/ou conseqüências, esperadas também não estão claras. A investigação tradicional da maturidade de carreira pareceu não considerar a influência dos fatores sociais, políticos e históricos no desenvolvimento da identidade vocacional. Portanto para a atualidade, a maturidade para a escolha da carreira deve ser usada segundo Silva (2004), quando se refere a questões típicas da adolescência, como a aquisição de atitudes e competências, bem como de informações para tomar decisões ao longo da carreira.

A utilização do conceito de maturidade para a escolha profissional, considerado processo crucial do desenvolvimento na adolescência, não é utilizado quando se trata de adultos, nessas situações existe o consenso para se utilizar o conceito de adaptabilidade. Para Silva (2004), o conceito de adaptabilidade significaria o conjunto das atitudes, das informações e competências necessárias para lidar prontamente com as mudanças verificadas no trabalho e nas condições de trabalho.

Em adultos o desenvolvimento de carreira é heterogêneo e não diretamente conectado coma a idade. Há um processo de reciclagem em que o desenvolvimento de carreira atravessa por várias etapas. E é por isso que o desenvolvimento de carreira em adultos é chamado de adaptabilidade de carreira. A visão desenvolvida é que os adultos podem gerenciar com mais desenvoltura e encontrar o melhor caminho para o desenvolvimento de sua carreira (NILES; HARRIS-BOWLSBEY, 2005).

Em uma importante reflexão sobre esse tema, os autores; Niles e Harris-Bowlsbey (2005) consideram o termo adaptabilidade de carreira adequado tanto para adultos como para adolescentes. Mesmo com a relativa homogeneidade no desenvolvimento de carreira, quando comparados com os adultos, os jovens experienciam diferenças em sua prontidão para a escolha de carreira. Alguns jovens encontram uma variedade de obstáculos (ex: pobreza, racismo, sexismo) que influenciam no desenvolvimento da escolha da carreira de uma forma negativa. Por outro lado, outros jovens contam com experiências (ex: oportunidades escolares e extracurriculares) que aceleram o desenvolvimento de carreira.

Sendo assim, esses diferentes contextos terão implicações na escolha e na prontidão da escolha de carreira. O termo adaptabilidade de carreira seria apenas mais adequado para os jovens com maturidade para a escolha de carreira. Segundo Savickas (1997 apud NILES; HARRIS-BOWLSBEY, 2005, p.43) "O termo adaptabilidade de carreira deveria substituir a maturidade de carreira como um construto crítico na perspectiva desenvolvimentista”. 
Depois de Super e de Crites, outros teóricos propuseram modelos relacionados à maturidade para a escolha de carreira, no entanto, nenhum destes alcançou o nível de refinamento e desenvolvimento dos primeiros (SILVA, 2004). A divulgação das idéias destes dois teóricos inspirou desde então estudiosos de todas as partes do mundo a investirem em pesquisas sobre maturidade profissional e para a escolha. Atualmente inúmeras publicações sobre o tema são divulgadas nas revistas científicas, com especial interesse na avaliação das relações existentes entre a maturidade profissional e determinadas variáveis sóciodemográficas, principalmente: sexo, idade, série escolar, etnia e nível socioeconômico.

O construto de maturidade para a carreira, criada há cinco décadas, conseguiu integrar de modo complementar as metodologias tradicionais de avaliação das capacidades, aptidões, interesses e os valores dos novos conceitos desenvolvimentistas em que se priorizam as condições do adolescente em incorporar construtivamente as informações para a escolha da profissão de uma maneira completa.

Nesse longo período muitas pesquisas já foram desenvolvidas e ainda se acredita ser esse campo ainda vasto para muitas investigações, em decorrência da evolução na produção do conhecimento, nos contextos nacional e internacional. Com esse intuito a próxima seção apresenta parte do estado da arte.

\subsubsection{Maturidade para a escolha da carreira: o estado da arte.}

Para fins deste estudo uma revisão da literatura foi realizada com base nos levantamentos no PsycINFO, disponível no portal http://www.portaldapesquisa.com.br, compreendendo o período de 1977 a 2006, por meio da palavra-chave career maturity. Foram obtidos 660 artigos, dos quais foram selecionados os que continham a palavra-chave no título ou no corpo do resumo. Observou-se que a maior parte dos estudos sobre a maturidade para a carreira é relacionada com uma grande variedade de temas, dentre eles, alguns mais próximos do objeto deste estudo, serão descritos a seguir.

O estudo de Shevlin e Millar (2006) aborda a importância da informação profissional para a decisão de carreira, adotando as teorias de desenvolvimento e escolha de carreira, os programas de educação de carreira e os conceitos de maturidade de carreira. O objetivo do estudo foi o de prognosticar o crescimento no comportamento de exploração de carreira em uma escola, podendo assim modelar níveis individuais e grupais de comportamentos de 
exploração de carreira e então identificar variáveis psicológicas que predizem tal comportamento.

Um estudo desenvolvido com o objetivo de identificar os efeitos de uma intervenção, selecionando dimensões de maturidade de carreira, foi realizado por Cassie (2006). As dimensões de maturidade de carreira avaliadas foram: as atitudes dos estudantes, atividade acadêmica, gênero, percepção das barreiras no desenvolvimento de carreira e a expressão da necessidade de assistência educacional e em planejamento de carreira. Os resultados evidenciam que as diferenças nas dimensões testadas eram expressivas em relação ao gênero. As demais dimensões não apresentaram medidas uniformes, demonstrando a complexidade do construto de maturidade de carreira.

Em outro estudo baseado originalmente nos estudos da teoria desenvolvimentista de comportamento vocacional, Hasan (2006) define a maturidade de carreira como as condições para o desenvolvimento de atitudes e competências relacionadas à escolha de carreira. Tais condições sofreriam influências diferentes nos diversos grupos culturais, raciais e de gênero, além de outros fatores psicológicos, educativos e demográficos. O autor desenvolveu um estudo com adolescentes indianos relacionando a maturidade de carreira em função do autoconceito, aspiração vocacional e gênero. E concluiu que estas variáveis são suficientemente potentes para provocar alterações na maturidade de carreira. Dhillon e Kaur (2005) desenvolveram um estudo investigando correlatos psicológicos de maturidade de carreira em uma escola pública.

Diversas linhas investigativas têm sido desenvolvidas por Creed e Patton (2004) no contexto australiano. Em um dos estudos dos referidos autores, eles sugerem o desenvolvimento e a validação de uma forma curta da versão australiana do Inventário de Desenvolvimento de Carreira (Career Development Inventory, CDI-A). Segundo os autores este instrumento promete ser um medidor de maturidade de carreira eficaz nas situações em que não é possível utilizar a versão inteira. Ainda são necessárias mais pesquisas de aplicação de testes e validação do instrumento. Os mesmos autores em outro estudo investigaram a maturidade profissional em relação à idade, sexo e nível socioeconômico na Austrália (CREED; PATTON, 2003).

Por sua vez, D’Achiardi (2006) investigou uma nova maneira de medir a maturidade de carreira em adolescentes, a partir do modelo desenvolvido por Super e Overstreet's. Os autores listam seis dimensões de maturidade de carreira usada para medir o construto durante a adolescência. O estudo avalia um programa de exploração de carreira construído especificamente para estudantes do Ensino Médio. Este programa foi elaborado para ser 
realizado em sete semanas, uma hora por semana e constam de exploração de características pessoais, informações sobre o mundo do trabalho e outros recursos disponíveis para favorecer a exploração de carreira. Foram realizados pré e pós-testes para avaliar o programa de exploração de carreira. Os resultados parecem demonstrar que os estudantes apresentam níveis diferentes de maturidade de carreira passíveis de serem mensurados. Foram encontradas diferenças de gênero, o sexo feminino teve maiores escores na maturidade de carreira que os meninos. Além desses resultados o programa trouxe benefícios aos estudantes. Entretanto, frente às limitações nas conclusões são necessários mais estudos para o desenvolvimento do programa de exploração de carreira.

Os efeitos da coesão familiar na maturidade de carreira foram estudados por King (1990) demonstrando efeitos significativos e por Flouri e Buchanan (2002). Os dados indicam que habilidades no trabalho e modelos de carreira foram positivamente associados, enquanto que pressões na escolha de carreira eram negativamente associados à maturidade de carreira. Assim, a estrutura da família e o status socioeconômico não tiveram relação com a maturidade de carreira, entretanto, a motivação acadêmica, o envolvimento materno e paterno e a autoconfiança eram relacionados à maturidade para a carreira.

Com relação ao sexo, em sua maioria as pesquisas conduzidas nas últimas duas décadas relatam que as moças são mais maduras profissionalmente do que os rapazes (PATTON; CREED, 2001, PATTON; LOKAN, 2001, PATTON; BARTRUM; CREED, 2004). Em relação à idade, a maior parte dos trabalhos conclui que há um aumento da maturidade profissional conforme a idade avança. Powell e Luzzo (1998) estudaram a influência de determinadas variáveis sócio-demográficas na maturidade de carreira de estudantes com idades entre 15 e 19 anos. Os autores relatam que, ao contrário dos resultados de pesquisas prévias, não houve diferença entre o nível de maturidade profissional e os fatores sexo, idade, série e etnia. Eles concluem que todos os estudantes obtêm benefícios com programas e atividades voltadas para o desenvolvimento de carreira e que seria prudente aos orientadores de carreira incluírem cursos ao longo da vida escolar sobre exploração de carreira e atividades de planejamento.

Por sua vez, Schmitt-Rodermund; Sibereisen (1998) e Lee (2001) também investigaram a influência de variáveis sócio-culturais na maturidade profissional de estudantes. SchmittRodermund; Sibereisen (1998) examinaram as diferenças na maturidade de carreira na Alemanha após a unificação do país, que passou por grandes mudanças sociais. Lee (2001) investigou a maturidade de carreira em estudantes americanos e koreanos que cursavam o Ensino Médio, mostrando que os americanos tendiam a apresentar maior maturidade na 
escolha profissional. Entretanto, é importante ressaltar que os estudantes são similares quanto ao construto maturidade de carreira, o que suporta o argumento teórico que a maturidade de carreira é um conceito universal e capaz de ser aplicado nas diversas culturas.

Além desses estudos sobre a maturidade profissional, outra vertente investiga a evolução da maturidade dos indivíduos antes e depois da participação em processos de intervenção. Um estudo desenvolvido nos Estados Unidos por Legun e Hoare (2004) investigou a alteração no nível de maturidade profissional de adolescentes em situação de risco submetidos a um procedimento de intervenção específico. Os resultados indicam que não foram encontradas diferenças estatisticamente significativas nos índices de maturidade profissional dos adolescentes antes e depois da intervenção. Os pesquisadores explicam a ausência de diferenças em função da curta duração do processo de intervenção e também sublinham a possibilidade de que as mudanças relacionadas à atitude dos adolescentes não teriam se manifestado na época da nova medição. O estudo de Carbonero e Tejedor (2004), na Espanha, avaliou a maturidade de estudantes antes e depois de uma intervenção de 13 semanas com alunos entre 15 e 19 anos, dois grupos, um experimental e um controle. Os resultados demonstram que os dois grupos evoluíram na maturidade profissional, no entanto o grupo experimental obteve melhores resultados em seus índices.

No Brasil, Lobato e Koller (2003) estudaram a maturidade profissional em relação ao sexo em 98 adolescentes do ensino médio, por meio do Inventário Brasileiro de Desenvolvimento Profissional (IBDP). Um estudo de Neiva (2003b) compara a maturidade profissional em estudantes do ensino médio da cidade de São Paulo, segundo o sexo e a série escolar por meio da Escala de Maturidade para a Escolha Profissional (EMEP), de Neiva (1999). Outro estudo, desenvolvido em Curitiba-PR por Neiva e colaboradores (2005), objetivou verificar diferenças no nível de maturidade para a escolha profissional de alunos do ensino médio segundo o sexo, o tipo de escola, o turno de estudos (matutino ou noturno) e a série escolar. No Rio Grande do Sul, Balbinotti e Tétreau (2006) exploraram as diferenças na maturidade profissional segundo o sexo, a idade, série escolar e tipo de escola (pública ou privada).

O estudo realizado por Neiva (1998) revela a validade e a fidedignidade da Escala de Maturidade para a Escolha Profissional (EMEP). Em uma amostra de 506 estudantes, os resultados indicaram que a EMEP é válida e precisa, concluindo que este instrumento pode ser utilizado como medida de maturidade para a escolha profissional de adolescentes. Em outro estudo Neiva (2000) avalia a utilidade da EMEP na avaliação da evolução dos indivíduos em um processo de orientação profissional. A amostra foi composta por 45 alunos 
do ensino médio de escolas públicas e privadas da cidade de São Paulo. A escala foi aplicada na primeira sessão da intervenção de orientação profissional e reaplicada na última. Os resultados demonstram que houve um aumento bastante significativo na pontuação de todas as sub-escalas da EMEP e na escala total após o processo de intervenção. A autora conclui pela validade da utilização do referido instrumento em procedimentos de avaliação sobre a evolução do orientando.

Um procedimento de orientação profissional foi avaliado por Melo-Silva; Oliveira; Coelho (2002), utilizando a EMEP antes e após o processo de intervenção, em 63 sujeitos com idades entre 15 e 19 anos na cidade de Ribeirão Preto-SP. Os autores concluem que o processo de orientação profissional influenciou positivamente o desenvolvimento da maturidade dos orientados. A sub-escala de Responsabilidade foi a única que não apresentou mudanças significativas. Os autores explicam esse achado em função do fato de que indivíduos que buscam a intervenção já estão previamente comprometidos com seu processo de escolha, portanto, apresentando altos índices de Responsabilidade desde o início do processo. Considerando os resultados de estudos divulgados até o momento, cumpre verificar se os achados serão corroborados ou não em estudos desenvolvidos com outras amostras e em outros períodos e com número maior de sujeitos. Questionam-se quais variáveis sóciodemográficas mais influenciam a evolução da maturidade para escolha profissional.

No Brasil tem sido crescente o número de estudos sobre o modelo desenvolvimentista proposto por Donald Super (OLIVEIRA; GUIMARÃES; COLETA, 2006), no intuito de buscar o aprofundamento em novas teorias e ferramentas que auxiliem o orientador profissional frente a todas as modificações do mundo do trabalho. A presente revisão se encerra permeada pelo mesmo objetivo e intuito.

Dentro do conceito de maturidade para a escolha da profissão, considera-se que para atingir certo nível de maturidade para a escolha é necessário o desenvolvimento de certas atitudes e a aquisição de determinados conhecimentos. O adolescente se encontra no estágio de desenvolvimento de carreira denominado “exploração”. Para explorar bem é fundamental a busca por informações profissionais.

\subsection{A Informação Profissional em processos de Orientação Profissional}

Neste tópico serão tratados alguns dados históricos da informação profissional no Brasil bem como pesquisas realizadas na área em vários países. Serão apresentados três 
recursos utilizados na Orientação Profissional para a busca por informação profissional: o primeiro e mais antigo é o modelo impresso, recurso disponibilizado nas bibliotecas e nos Serviços de Orientação Profissional. E posteriormente serão apresentados programas informáticos e dos sites da internet.

A informação sobre as profissões tem um papel essencial e durante muito tempo foi quase a única prática de orientação educativa. Ela é empregada no processo de Orientação Profissional para ampliar o conhecimento sobre as profissões, corrigir as distorções e idealizações das profissões, criar estratégias de ação e conhecer as oportunidades e limitações no mercado de trabalho, além de sugerir objetivos e clarificar os caminhos para atingi-los. Na perspectiva educativa, pode modificar as representações que o sujeito pode ter do mundo do trabalho, enriquecendo, corrigindo e reestruturando-as (GUICHARD; HUTEAU, 2001).

Há mais de 30 anos Kunze ${ }^{3}$ (1967, apud BROWN, 2003, p. 194) descrevia um modelo de informação ocupacional que minimamente revisado continua relevante nos dias de hoje. $\mathrm{O}$ modelo inclui:

1- material impresso (livros, guias, informativos sobre carreiras e mercado de trabalho, reportagens),

2- materiais programados,

3- materiais audiovisuais, como filmes e vídeos,

4- programas de multimídia que contêm componentes interativos, videoclipes e gráficos,

5- publicações armazenadas online,

6- simulação de situações reais de trabalho utilizando CD-ROM e o role play,

7- jogos,

8- Laboratório Ocupacional,

9- entrevistas com trabalhadores,

10- observação direta através de visitas ao local de trabalho,

11- experiências de exploração direta em amostra do trabalho,

12- experiências de estágios em período temporário e

13- sites da internet.

Todos esses diferentes tipos de informações profissionais têm seus pontos favoráveis e desfavoráveis, principalmente ao se considerar alguns critérios importantes no momento de optar por algum deles. O primeiro critério é a viabilidade do custo dos materiais, depois é a

\footnotetext{
3 KUNZE, K. R. Industry resources available to counselors. Vocational Guidance Quartely, 16, p 137-142, 1967.
} 
postura de envolvimento do orientando quando utiliza os instrumentos e finalmente, a acessibilidade aos materiais (BROWN, 2003).

Dentre as várias opções sugeridas, algumas tentativas foram realizadas, no Brasil, com o intuito de colocar na grade curricular das escolas uma disciplina sobre informação profissional. Um exemplo dessa época foi na década de 1970, no Brasil, da elaboração de uma nova disciplina para o Ensino Médio, chamada de Programas de Informação Profissional (PIP), através da Secretaria da Educação do Estado de São Paulo (Lei 5.692/71 de Diretrizes e Bases). A proposta de atividade curricular nas escolas públicas do Estado de São Paulo era promover a informação e a orientação profissional, que facilitariam o conhecimento do mercado para a escolha da profissão. A proposta vigorou por cinco anos, e acabou extinta por falta de preparo das escolas para realizar a disciplina apropriadamente (LOBO, 2005).

Um outro exemplo com o mesmo nome mais desenvolvido recentemente é o Programa de Informação Profissional (PIP), a informação profissional presencial é desenvolvida como uma etapa do processo de escolha profissional. Segundo Medico (2005), que desenvolveu o programa, a Orientação Profissional não pode limitar-se à última série do Ensino Fundamental e Ensino Médio, quando o jovem está pressionado pela obrigatoriedade da escolha. A autora sugere o início da orientação nas primeiras séries da escolarização, a desenvolver-se como um processo contínuo, paralelo ao desenvolvimento geral do indivíduo. A estratégia de intervenção na literatura internacional é denominada de Educação para a Carreira.

Frente a todas as modificações no mundo do trabalho, a informação profissional foi e continua sendo mais importante ainda para o processo de tomada de decisão dos adolescentes. O alcance à informação profissional pode funcionar como um instrumento facilitador na escolha da carreira na medida em que é objetivo da Orientação Profissional, auxiliar o adolescente na realização de escolhas conscientes e autônomas, baseadas em informações precisas sobre a realidade. Cabe ao orientador estar ciente das dificuldades e mudanças especialmente significativas para o adolescente nessa etapa do ciclo evolutivo.

Os conselheiros para a carreira desempenham um papel importante ajudando clientes a acessar informações precisas e atuais sobre o mundo do trabalho. Dar aos clientes recursos e informações úteis tornou-se mais desafiador, devido às rápidas alterações na natureza do trabalho. Assim, é importante que os indivíduos tomem decisões informados sobre o trabalho que escolheram (NILES, 1997, p.123).

Segundo Niles (1997) a informação de carreira pode ajudar os clientes a tomar decisões, entretanto os orientadores devem se certificar que as mesmas sejam precisas, 
relevantes e recentes, de modo a aumentar a probabilidade dos clientes de obterem informação adequada sobre a carreira, encorajando-os a usar fontes múltiplas de informação como: empregadores, livros, sistemas de orientação à carreira mediada por computador e profissionais empregados em ocupações de interesse dos clientes.

Assim, como salienta Brown (2003), cada jovem tem necessidades únicas, cabe ao orientador profissional conhecer a extensa possibilidade de materiais disponíveis. O estudante que apenas iniciou a sua pesquisa no vasto mundo do trabalho terá necessidade de explorar amplamente todas as profissões, mas de uma forma breve. Enquanto que aqueles que estiverem em um momento mais seletivo de afunilar suas escolhas estarão ansiosos por respostas mais específicas para suas dúvidas.

Compreender como as ferramentas de informação e comunicação influenciam o jovem na busca e no processamento de informações relativas à carreira, tendo em vista a tarefa de tomada de decisão vocacional, portanto, será útil para produção do conhecimento. Na adolescência, o crescimento se desenvolve gradualmente, vão se adquirindo atitudes e competências $^{4}$, e reunindo as informações necessárias para lidar com as decisões ao longo da carreira. A tomada de decisão deveria acontecer quando o adolescente estivesse pronto para escolher, o que exigiria dele a aquisição de conhecimentos, tanto relativos ao autoconhecimento quanto ao conhecimento da realidade social.

O mundo do trabalho com o advento do desenvolvimento tecnológico apresenta diferenças, o que implica necessariamente em adaptações no processo de escolha ocupacional. O trabalho como é conhecido vem sendo substituído pelo "trabalhador do conhecimento e da economia globalizada” (LUZ FILHO, 2002, p.24). Na era da informação, é importante definir e identificar o papel da informação como componente do processo de Orientação Profissional, utilizada como esclarecimento. Há a importância de questionar a sua qualidade e a razão de existir nesse novo contexto.

A informação profissional pode ser compreendida como um dos componentes do processo de Orientação Profissional que tem como objetivo básico fornecer dados que auxiliam a tomada de decisão. Esses dados se dividem em dois conjuntos: o primeiro a respeito das informações profissionais e o segundo a respeito do próprio indivíduo que escolhe (autoconhecimento).

\footnotetext{
${ }^{4}$ Competência é compreendida como capacidade, aptidão, saber fazer bem. E este saber fazer bem possui duas dimensões: técnica, isto é, do domínio dos conteúdos que o sujeito necessita para desempenhar seu papel; e a política, pela qual se vai ao encontro daquilo que é desejável, que está estabelecido valorativamente com relação à sua atuação (RIOS, 1993; MELO-SILVA, p. 69-90, 2003).
} 
A informação profissional, que consiste em familiarizar o cliente com o mundo das profissões, considerando-se que para a escolha acertada entre as múltiplas profissões existentes é necessário o conhecimento das oportunidades e requisitos dessas profissões, mormente aquelas que interessam ao cliente. Para esse fim são utilizados folhetos informativos, palestras, visitas, entrevistas com representantes das várias profissões e outras atividades que, integradas, permitam ao cliente uma visão clara e objetiva da realidade profissional (Dicionário de Ciências Sociais, 1987, p.851).

Os conflitos e problemas na escolha de carreira acontecem muitas vezes por carência de informação com respeito ao seu futuro. Assim, a Orientação Profissional oferece subsídios para informar e ao mesmo tempo corrigir as imagens distorcidas que o adolescente já possui sobre o mundo adulto. Para Bohoslavsky (1991), as falhas na transmissão e/ ou recepção da informação podem ser de ordem intrapessoal (características pessoais), interpessoal (dificuldades na identificação com pessoas / profissões) e transpessoal ou cultural (a valorização de algumas profissões em uma comunidade, com atribuição de poder, status).

As informações sobre as profissões, por mais objetivas que sejam, são internalizadas pelo indivíduo tanto consciente quanto inconscientemente, a partir de valores culturais e sociais adquiridos no convívio social e familiar. Neste processo, criam-se expectativas de atuação profissional e a respeito de si próprio que, segundo Ferretti, são "deficiências do indivíduo" que precisam ser sanadas no processo pelo orientador profissional. Em alguns serviços de Orientação Profissional enfatiza-se a informação como elemento principal no processo de escolha, fato que restringe consideravelmente a discussão que deveria ser mais ampla, na sua função ideológica:

[...] deve-se considerar que o poder influenciador atribuído à informação profissional funda-se num raciocínio lógico: se alguém deve se decidir por diferentes formas de ação, essa decisão será tanto mais confiável quanto mais e melhor informado o indivíduo estiver sobre essas formas de ação e sobre as possíveis conseqüências que advirão do privilegiamento de uma alternativa e exclusão das demais. Esse raciocínio tem servido de fundamento ao processo de Orientação Profissional (FERRETTI, 1988, p.55).

Os objetivos da informação não consistem, para Bohoslavsky (1991), apenas em fornecer informação, mas considerar as informações que o adolescente traz consigo, seus questionamentos e preconceitos (quem será o receptor da informação), a informação transmitida de maneira ativa, promovendo questionamentos (como se deve informar). E finalmente o que é importante informar sobre as diferentes atividades profissionais, alguns itens são: os objetivos e finalidade social de cada profissão, as técnicas e instrumentos 
utilizados, a demanda atual do trabalho, os lugares em que se realizam, as relações com outras profissões e a forma de acesso às mesmas considerando as possibilidades socioeconômicas do adolescente.

Ao salientar a necessidade da informação na escolha profissional, devem-se considerar os fatores econômicos, políticos e sociais que interferem nas possibilidades de escolha, sem minimizar a questão social e a complexidade atual do mundo do trabalho, como já apontava Ferretti (1988),

Evidentemente, a ninguém ocorrerá negar a necessidade da informação na realização de opções. Todavia, uma coisa é admiti-la como condição necessária, outra é dá-la como condição suficiente. Outra, ainda, é minimizar a complexidade da decisão enquanto fenômeno social (FERRETTI, 1988, p.56).

Ainda que as referências a Bohoslavsky e Ferretti datem de épocas anteriores ao advento da internet e das TICs, elas permanecem válidas em termos de destacar a importância cada vez maior da qualidade e fidedignidade da informação profissional na época atual marcada pela efemeridade.

O adolescente, em geral, possui algum tipo de informação sobre as profissões adquiridas no cotidiano familiar, escolar e social. À medida que caminham para a escolha da sua carreira, questões específicas e pessoais emergem e precisam ser tratadas de maneira individualizada nos seus conteúdos. A informação fornecida pelo orientador pode ser restritiva ou ampla e em ambas é importante um questionamento ético, para a escolha das informações pertinentes. Algumas questões são colocadas, como sugerem os autores, em suas palavras: "Como fazer a escolha? Quais são os traços salientes de uma formação ou de uma profissão? É verdade que o conselheiro deve ser bem informado, mas ele corre sempre o risco de dar informações aproximativas ou enviesadas” (GUICHARD; HUTEAU, 2001, p 329).

A informação que pretende ser honesta, fidedigna em relação à realidade do mundo contemporâneo precisa refletir todas as incertezas do momento, propiciando uma reflexão ampla e crítica. Sendo a informação profissional empregada adequadamente no processo de orientação profissional, ela promove a...

[...] ampliação do conhecimento sobre as profissões existentes e suas especializações; ampliação do conhecimento sobre as alternativas de ação, bem como a redução da gama dessas alternativas; correção de distorções nas imagens das profissões; desenvolvimento de expectativas mais realistas; consciência da necessidade de utilização de informações válidas e fidedignas nas escolhas; maior conhecimento das oportunidades locais de trabalho (FERRETTI, 1988, p.54). 
A Informação Profissional é definida como: “Componente do processo de formação profissional, mediante o qual se fornecem esclarecimentos e orientações sobre o universo e as características do campo profissional, quanto às condições reais do mercado de trabalho local e suas tendências” (Ministério de Trabalho, 1981, p.28). Assim, além da informação sobre as formas alternativas de acesso e permanência na universidade, é necessário disponibilizar dados sobre as carreiras universitárias, tecnológicas e técnicas, sobre as profissões e ocupações; os vários tipos de escolas e suas graduações e certificados; auxílio em financiamentos; políticas públicas vigentes; empregos e mercado de trabalho.

O adolescente está cercado de novidades, tanto no seu mundo interno como no convívio social, o mundo globalizado, as novas políticas públicas, as inúmeras possibilidades de utilização da internet, as diversas possibilidades de trajetórias ocupacionais. Para uma reflexão mais ampla torna-se necessário analisar tanto os meios tradicionais de adquirir informações como os mais modernos por meio da internet. Existem também outros métodos de coletar informação profissional que podem ser utilizados, como: feiras das profissões; palestras de profissionais das diversas áreas; visitas ao local de trabalho da profissão; entrevistas com os profissionais; estágios (remunerados ou não, que criam oportunidade de vivenciar a rotina de trabalho) e mais recentemente os serviços de ajuda por telefone, como aponta Watts (2002), existentes nos Centros de Orientação de Carreira em países desenvolvidos. Tais centros constituem espaços apropriados para orientar estudantes na escolha de carreira, assim como pessoas à procura de emprego. Nesses Centros existem vários recursos para pesquisa, como: vídeos, jornais, livros, programas de computador e internet (NILES; HARRIS-BOWLSBEY, 2005).

A informação profissional que se encontra disponível na forma de guias e revistas de Universidades apresenta poucos conteúdos e pode ser questionada em sua parcialidade e no envelhecimento muito rápido dos dados. Por outro lado, nas informações disponíveis em sites via internet, o conteúdo é amplo e variado, sendo os dados renovados facilmente. Esses tipos de sites são bastante freqüentes na Europa e nos Estados Unidos, e demais países desenvolvidos, inclusive no auxílio para a busca de emprego, como será citado no próximo tópico.

Quanto à informação disponível na mídia escrita, Ferretti (1988) realizou um levantamento das publicações da época (catálogo de cursos de $2^{\circ}$ e $3^{\circ}$ graus, cursos e profissões no Brasil, manual do candidato, folhetos de informação profissional) que tratam da informação profissional para o adolescente. Uma das características dos materiais analisados é a forma concisa de apresentação dos dados, que muitas vezes representa uma seleção do 
conteúdo e da qualidade da informação que deixam a desejar. Outras características são a objetividade, a simplicidade e a neutralidade de que o dado vem revestido, não incluindo questões e reflexões para promover uma análise crítica. E por fim o texto das informações e os dados pouco diferem de um para o outro texto, normalmente tratam de: descrição das atividades profissionais, locais de trabalho, mercado de trabalho, qualidades pessoais exigidas pela profissão e dados sobre o curso de formação.

Esse levantamento permanece bastante atual quando se observam os guias e catálogos impressos disponibilizados atualmente, que em sua maioria pouco mudaram das características apontadas pelo autor. “Ao veicular informação da forma como o fazem, os textos, na verdade, não deixam de emitir juízos de valor” (FERRETTI, 1988, p. 70). A Orientação Profissional, para ser eficaz, deve ter por objetivo básico o fornecimento de informações fidedignas sobre profissões a fim de estimular a reflexão e o pensamento crítico sobre o seu exercício na sociedade. Para Guichard; Huteau (2001), a informação, ao ir além de uma simples descrição das formações e das profissões, veicula visões da sociedade que darão determinado sentido ao desenvolvimento profissional, o que nem sempre segue explicitado.

Com o intuito de resumir as idéias colocadas nesse estudo sobre esse assunto e facilitar o entendimento, serão apresentados, a seguir, os métodos mais utilizados atualmente com as vantagens e desvantagens de sua utilização, segundo os autores Robinson et al (2000). Segundo esses autores a informação profissional pode ser agrupada em três modelos gerais: (1) material impresso, (2) sistemas de computador (Computer-Assisted Career Guidance CACG systems) e (3) a internet, apresentando as vantagens e as desvantagens tanto na qualidade da informação sobre as carreiras quanto do mecanismo de acesso às informações, conforme síntese apresentada a seguir.

O primeiro modelo consiste na informação de carreira realizada por meio de material impresso. As informações podem ser obtidas em bibliotecas (livros, artigos, reportagens), banco de dados do governo e associações profissionais. As vantagens neste modelo são: a assistência humana e a leitura de documentos no lugar da leitura no computador. Por outro lado há desvantagens como, por exemplo, a pessoa precisar se locomover até o local dos recursos, a informação se tornar obsoleta e os recursos serem roubados e perdidos. Nesse modelo os mecanismos de acesso podem ser: recursos da biblioteca, relação face a face com o orientador profissional, utilização de papel, lápis, exercícios sobre temas e o atendimento em dinâmicas de grupo ou individualmente. Nesse modelo as vantagens são: acesso mais formal, comumentemente aceito e respeitado, as pessoas se beneficiam do vínculo com os demais e 
são observados benefícios nas trocas entre as pessoas sobre suas experiências. As desvantagens são: locomoção até o local do serviço de Orientação Profissional, o recurso da biblioteca pode se perder ou expirar, requer intervenção humana, algumas pessoas são ansiosas quando testadas, há variedade multicultural, tempo maior para ter os resultados, não há acesso direto às informações, necessitando que o orientando faça a busca.

O segundo modelo consiste em informações através do Sistema CACG. As informações são localizadas em bibliotecas, a informação está no sistema CACG (ex: SIGI PLUS, DISCOVER) e as fontes podem ser do governo e/ ou de recursos independentes. As vantagens são: a pessoa pode localizar várias ocupações diferentes em um mesmo local, utilização de cores/ gráficos e outros recursos. Como desvantagem os autores apontam que é preciso locomoção até o local dos recursos, a informação pode se tornar obsoleta e muito geral. Nesse modelo o mecanismo de acesso é direto, há várias avaliações de dimensões psicológicas e educacionais como: valores, interesses, habilidade, experiências e o sistema normalmente é utilizado sem aconselhamento. As vantagens mencionadas são: pode ser autodirigido, há anonimato, algumas interfaces entre as avaliações e as informações, o resultado é instantâneo, a utilização pode ser armazenada e os programas são específicos para as etapas do desenvolvimento/ ano escolar. As desvantagens são: locomoção até o local do serviço, rigidez, validade, relevância multicultural não é considerada e a limitação da habilidade do usuário na utilização.

O terceiro modelo consiste na “informação obtida por meio da internet. A informação está localizada na internet, nas mais diferentes web sites e as fontes podem ser do governo, de associações profissionais e, ainda, publicações educacionais e de universidades. E as vantagens? São várias, pois há muitos sites com múltiplos recursos, a pessoa pode procurar informações nas mais variadas ocupações, o recurso é prioritariamente visual, há flexibilidade, informações rápidas e atualizadas, os sites são elaborados para populações específicas e a internet é um recurso moderno, popular e utilizado cada vez mais por todos, sobretudo por adolescentes. Porém, algumas vantagens são apontadas, a principal é que sem Orientação Profissional muitas informações podem ficar perdidas, sem sentido para a pessoa. Qual informação profissional é confiável? Esse modelo requer manutenção constante. Os mecanismo de acesso nesse modelo são: pelo computador, nos vários sites disponíveis e poucos sites interligam a avaliação com as informações de carreira. As vantagens apontadas são: permite o acesso por qualquer computador ligado à internet, anonimato, permite opção de ir/voltar por vários caminhos entre avaliação e busca da informação, individualidade na escolha dos caminhos culturalmente relevantes e o resultado é instantâneo. Como principal 
desvantagem destaca-se que: não há intervenção humana direta, o acesso é desigual, pode não ser adequado para as condições emocionais e a variedade na validade e qualidade pode dificultar uma intervenção eficaz (ROBINSON, et al., 2000).

Como apontado anteriormente, a informação profissional continua sendo relevante no processo de Orientação Profissional, ainda que apresentando inúmeras variações e limitações nos diferentes modelos disponíveis. Nesse sentido, investigar procedimentos de intervenção focalizando a informação profissional pode contribuir para a produção do conhecimento teórico e prático.

A fim de continuar as reflexões sobre a informação na atualidade, o item seguinte tratará das tecnologias disponíveis que podem ser utilizadas pelos adolescentes e orientadores para acessar as informações a cerca das profissões e facilitar a escolha profissional. Estas denominam-se: Tecnologias de Informação e Comunicação (TIC). A TIC será abordada, em seu desenvolvimento ao longo do tempo, suas aplicações e demandas na área, a fim de melhor se compreender a informação acessada pelos jovens através dos sistemas de computador (Computer-Assisted Career Guidance - (CACG) systems) e pela internet.

\subsubsection{A Tecnologia da Informação e Comunicação (TIC) na Educação e Orientação Profissional: o estado da arte.}

As tecnologias da informação e comunicação representam uma nova oportunidade de crescimento e desenvolvimento para a Orientação Profissional, com desafios e limites a serem traçados em um campo que não pára de evoluir. A seguir serão discutidos os dois tipos de acesso às informações através das tecnologias disponíveis na atualidade: os programas de computador no auxílio da orientação de carreira e a internet com toda a variedade de sites disponíveis na www. O interesse nesse estudo é sobre o uso da internet pelos jovens em processo de orientação.

Algumas das pesquisas tratadas nesse item foram selecionadas dos levantamentos realizados no PsycINFO, disponível no: http://www.portaldapesquisa.com.br, no período de 1962 a 2007, por meio da palavra-chave career information. Foram obtidos 397 artigos, dentre os quais foram selecionados apenas os que continham a palavra-chave no título ou no corpo do resumo e que se aproximavam mais do objeto deste estudo.

Em sua maioria, orientadores profissionais e pesquisadores percebem a importância da influência da Information and Communication Technologies (ICT) ou Tecnologia da 
Informação e Comunicação (TIC) para a Educação e Orientação Profissional. O número crescente de websites de informação de carreira é cada vez maior em números, como também vem se alastrado pelos mais diversos países. O sucesso da internet tem contribuído para o crescimento da importância da TIC em todo o campo da Orientação Profissional (ESBROECK, 2002).

A situação merece uma cuidadosa avaliação, principalmente para os orientadores profissionais que não têm acesso aos computadores e à internet. Um grande número de pessoas não têm acesso às facilidades das novas tecnologias, o que acontece nos países em desenvolvimento com discrepantes diferenças entre os grupos socioeconômicos, criando a “divisão entre os que têm e aqueles que não tem” (ESBROECK, 2002, p. 137).

Outra importante questão apresentada por Esbroeck (2002) é se as pessoas que têm acesso à internet e aos computadores fazem realmente uso dos mesmos. O referido autor cita uma pesquisa realizada na Universidade de Bruxelas em que o uso da internet entre os estudantes para procurar informações em programas de educação foi avaliado, identificando que a maioria dos estudantes prefere utilizar a tradicional impressão no papel à virtual. Algumas pessoas encontram barreiras pessoais ou sociais que as impedem de fazer um uso efetivo das oportunidades da TIC. Para o referido autor, algumas dessas barreiras podem estar associadas às próprias facilidades das TICs.

Segundo Watts (2002), a evolução da utilização da TIC no campo da Informação de Carreira e da Orientação Profissional pode ser dividida em quatro fases. Na primeira fase, de construção, que data de meados da década de 60 e início de 70, foram desenvolvidos os primeiros sistemas em Orientação Profissional demonstrando o potencial da TIC, em países do primeiro mundo. Entretanto, o custo e a interação com os usuários eram restritos. Naquela época ocorreram as primeiras aplicações da informática na avaliação psicológica, sendo a utilização basicamente para a correção de testes e de provas psicométricas que realizavam análises estatísticas longas e sofisticadas.

A segunda fase para Watts (2002) é a do microcomputador, que aconteceu na década de 80 até meados de 90. A utilização do computador começa a se tornar mais viável economicamente e o desenvolvimento de software em versões de utilização facilitadas e com mais recursos. Conseqüentemente, houve um crescimento no número de sistemas em Orientação Profissional, como de sua utilização nos países desenvolvidos. A terceira fase ocorreu no final dos anos 90, com o advento da internet. As websites se desenvolveram e as pessoas podiam acessar instantaneamente vários sites diferentes, inclusive em sua casa. A facilidade de intercomunicação fez com que as websites produzissem um crescimento 
massivo. Nesse momento ocorreu a criação dos sites com diferentes propósitos nos serviços de Orientação Profissional. Por fim, a quarta fase é a digital, que se desenvolve atualmente, onde a televisão e o telefone estão entrando junto com o computador na era digital. As pessoas agora podem acessar a internet não apenas através do seu computador pessoal, mas também através da televisão e dos aparelhos celulares.

No decorrer das quatro fases, para Watts (2002), foram se adicionando vantagens como: o crescimento na facilidade dos acessos (a orientação e a informação profissional por meio das TIC’s acessíveis a várias pessoas e de qualquer lugar), a maior interatividade entre os usuários e os vários sistemas e a facilidade em se desenvolver websites por iniciativa privada. Este processo conseqüentemente também gerou desvantagens, as quais serão discutidas ao longo do texto.

Os programas informáticos de Orientação Profissional são de vários tipos, a seguir alguns serão apresentados. O primeiro deles são os sistemas ou instrumentos de avaliação, neste programa o próprio sistema administra um ou mais testes ou inventários de interesse, de habilidades, características de personalidade que em seguida são interpretados e indicam as possíveis profissões. Um exemplo é o Kuder Career Search with Person Match, desenvolvido por Kuder e Kytowski em 1999 disponível no site http://www.kuder.com. Um outro tipo de sistema é o que fornece informações sobre a profissão, locais de trabalho, mercado, universidades disponíveis; são especializados em banco de dados e pesquisas. Dentro deste tipo de sistema podem-se diferenciar dois tipos: o sistema de informação de carreira do governo e os sistemas disponíveis comercialmente no mercado.

E o último tipo são os sistemas analógicos que através de sistemas de aprendizagem auxiliam o usuário a efetuar a decisão profissional. Eles auxiliam a desenvolver planos de ação, preparar currículo, preparar e selecionar entrevistas, aprender a selecionar oportunidades ou investir no próprio negócio, contendo uma grande variedade de informações profissionais (GUICHARD; HUTEAU, 2001; WATTS, 2002; NILES; HARRIS-BOWLSBEY, 2005). Estes programas são nomeados: sistemas de computador no auxílio da orientação de carreira, Computer-Assisted Career Guidance (CACG) systems.

Segundo Niles e Harris-Bowlsbey (2005), os primeiros teóricos (Katz, Super e Tiedeman) a desenvolver esses sistemas para computador acreditavam que os mesmos poderiam ser uma forma de ensinar as suas teorias diretamente aos usuários, internalizando o aprendizado. Estes primeiros sistemas eram baseados em modelos teóricos. E um exemplo dessa época é o System for Interactive Guidance Information (SIGI) desenvolvido por Katz em 1963. Depois disso, Super desenvolveu o Education and Career Exploration System 
(ECES), quando trabalhava como consultor da Cooperativa IBM. Este sistema operacionalizou algumas partes do trabalho teórico de Super. Através do subsídio da Universidade de Harvard, David Tiedeman em 1963 desenvolveu o Information System for Vocational Decisions (ISVD), com objetivo de ensinar ao usuário a transpor os sete degraus na escolha de carreira. A grande sofisticação deste programa não acompanhou a tecnologia do momento e o programa não se tornou operacional na época.

Nas teorias de Orientação Profissional, a perspectiva mais antiga é psicotécnica, os sistemas analógicos fazem parte da prática psicotécnica clássica. A psicotécnica não é uma teoria psicológica, caracteriza-se por um conjunto de técnicas e de práticas sociais. Algumas das suas proposições são: os indivíduos podem ser descritos por aptidões estáveis, as profissões podem ser descritas pelas suas exigências estáveis, os indivíduos são capazes de tomar decisões racionais. Esse modelo é chamado de teorias traço-fator (apresentada pela primeira vez por Frank Parsons em 1909) que visavam emparelhar o perfil do indivíduo com o perfil da profissão (GUICHARD; HUTEAU, 2001).

Os primeiros programas a entrar no mercado, elaborados na década de 1960 pela comissão de Emprego e Emigração do Canadá, eram baseados nessa teoria. O protótipo utilizado numa perspectiva educativa é o Computerized Heuristic Occupational Information and Career Exploration System (CHOICES). A partir dessa versão outros foram criados em função do público visado. Um deles é o programa CHOIX I utilizado para os jovens de 10 a 15 anos, CHOIX II para os estudantes com mais de 15 anos, o CHOIX E. F. para os estudantes de cursos superiores, ETAPAS DE CARREIRA para a inserção profissional de adultos. O programa CHOIX II foi adaptado para a maioria dos países europeus, o que normalmente não acontece. "É um caso único porque, regra geral, os programas informáticos deste tipo não são adaptáveis. As suas bases de dados são nacionais e veiculam valores e concepções da orientação próprias de uma dada cultura” (GUICHARD; HUTEAU, 2001, p.303).

Esses programas foram desenvolvidos com base nas concepções teóricas predominantes na época (traço-e-fator), seguiam planos de carreira, oferecendo uma seqüência de atividades para o usuário. As descrições dos indivíduos e das atividades profissionais são feitas por meio de traços definidos pela análise fatorial. Uma das desvantagens desses programas dos sistemas analógicos era a impossibilidade em alguns momentos de correspondência dos perfis individuais com uma profissão. Além disso, por serem baseadas na teoria traço-fator, ficam muito ligadas a aptidões e pelos interesses que são estáveis. Nessa perspectiva, ao se estabelecer uma boa correspondência entre as aptidões e as 
exigências das diversas profissões ou atividades profissionais permitir-se-ão o sucesso e a satisfação individuais (GUICHARD; HUTEAU, 2001).

Mais recentemente a análise das relações entre a variabilidade individual e as condutas de orientação foi renovada pela contribuição da corrente interacionista, no campo da psicologia da personalidade e da psicologia cognitiva, que consideram as características individuais e suas variações (GUICHARD; HUTEAU, 2001). Essas últimas proposições começam a se enquadrar mais no mundo atual onde se fala em competências a serem desenvolvidas ao longo do tempo.

Os programas informáticos de ajuda à decisão são na maioria de autoconhecimento e o conhecimento do mundo profissional. O sistema foca a base de dados e as estratégias de pesquisa e por meio desses conhecimentos o sujeito estaria apto para tomar uma decisão. Nesses programas podemos distinguir três tipos, segundo Guichard e Huteau (2001). O primeiro tipo, eliminação por aspecto, parte de um conjunto de profissões que vão progressivamente sendo eliminadas pois não correspondem aos critérios exigidos pelo sujeito. O problema encontrado nesse sistema é que os critérios são avaliados independentemente uns dos outros. O sistema CHOIX citado anteriormente funciona desta forma.

O segundo tipo é o acasalamento das representações, que ensina o sujeito a relacionar a representação que faz de si mesmo com as diversas profissões. Esses programas incidem mais sobre a exploração do que sobre a decisão e o módulo de ajuda à decisão do DISCOVER é um deles. O DISCOVER foi desenvolvido pelo American College Testing Program sob a direção de Jo Ann Harris (GUICHARD; HUTEAU, 2001).

O terceiro tipo, os cálculos de utilidade têm por base a teoria da decisão que considera que a "boa decisão” é aquela que maximiza a utilidade subjetiva esperada. "Cada profissão tem uma certa utilidade que é função da importância atribuída pelo sujeito aos diversos valores que ela é suscetível de satisfazer; o sujeito tem igualmente uma certa probabilidade de acender a cada uma das profissões consideradas” (GUICHARD; HUTEAU, p.306, 2001). O programa ACOR (Ajuda à Escolha em Orientação) e o módulo de ajuda à decisão de System of Interactive Guidance and Information (SIGI Plus) são exemplos desses princípios. O SIGI foi desenvolvido pelo Educational Testing Service sob a direção de Martin Katz em 1963 e deu origem ao SIGI Plus.

Os programas informáticos mais ambiciosos são os sistemas de aprendizagem que pretendem alcançar quatro objetivos: autoconhecimento, conhecer o mundo do trabalho, adquirir competências para a tomada de decisão e transferi-las para o mundo escolar e do trabalho. Os três sistemas de aprendizagem existentes são o DISCOVER, SIGI PLUS e o 
PROSPECT. O DISCOVER E SIGI PLUS tiveram suas primeiras versões nos anos de 1970. O PROSPECT é mais recente, nos anos de 1990, utilizado na Grã-Bretanha para a orientação e inserção profissional dos estudantes (GUICHARD; HUTEAU, 2001).

As avaliações sobre esses programas incidiram principalmente nos programas DISCOVER e SIGI, utilizados por milhões de pessoas nos Estados Unidos. Ao se avaliar os efeitos desses programas, para os usuários a satisfação ficou em torno de 90\%. Os programas foram considerados úteis e interessantes. Entretanto, estes programas informáticos evoluíram pouco nos últimos anos. A primeira razão é de ordem teórica, pelo fato de que as idéias sobre o processo de elaboração das intenções de futuro não se alteraram significativamente, e por isso não há sentido que os programas se alterem. E a outra razão é de ordem econômica, pois a construção e a manutenção demandam grandes investimentos (GUICHARD; HUTEAU, 2001).

Desde os anos 1960 até hoje a tecnologia vem trazendo avanços em relação à assistência a pessoas em processo de planejamento de carreira. As capacidades do computador atualmente são: administrar e interpretar testes e inventários, pesquisar dados, transpor dados de uma base para outra mais específica (crosswalking), encontrar base de dados específica para a necessidade de um usuário, monitorar o progresso do usuário através do processo de planejamento de carreira, fornecer instruções específicas (exemplo: como escrever um resumo ou como conduzir uma entrevista) e encontrar fontes de pesquisas específicas (NILES; HARRIS-BOWLSBEY, 2005).

Os autores, Reile e Harris-Bowlsbey (2000) listam os dez recursos mais utilizados atualmente na internet e suas implicações para os profissionais em Orientação Profissional, elencados a seguir.

1- Procurar por informação profissional é a utilização mais popular, proporcionando aos orientados ajuda no sentido de encontrar a informação de que necessitarem.

2- Ler as novidades locais como as globais mantendo o orientador informado e atualizado.

3- Administrar a carreira, através da utilização dos vários sites disponíveis.

4- Aprender novidades teóricas e práticas sobre a Orientação Profissional.

5- Baixar em seu computador novas ferramentas ou mesmo acessa-las junto com o orientado.

6- Obter informações referentes a outras localidades, como de conferências, e outras.

7- Socializar com outros orientadores profissionais, como com os orientados. 
8- Possibilitar investimento financeiro nos centros de Orientação Profissional, através dos sites de carreira.

9- Jogar (games), os orientadores podem acessar sites utilizando jogos que ensinam a planejar a carreira e a procurar por trabalho.

10- Comprar online, os orientadores profissionais podem utilizar os sites de venda para compra de livros dos vários países.

Algumas outras formas de utilização da internet mais específicas da Orientação Profissional são possíveis, como apontado na seqüência.

1- A utilização de inventários de interesse, de habilidades, de tipos de personalidade.

2- A identificação de alternativas ocupacionais que combinem com as características pessoais.

3- Buscar informações sobre as ocupações incluindo possíveis comparações entre elas.

4- Buscar informações sobre as oportunidades educacionais disponíveis.

5- Procurar emprego (REILE; HARRIS-BOWLSBEY, 2000).

O orientador profissional no processo de escolha da carreira poderá estar envolvido diretamente com o orientando, na utilização de todos esses recursos disponíveis na internet. Para Reile e Harris-Bowlsbey (2000), quando os orientandos utilizam esses instrumentos na internet alguns passos devem ser seguidos pelo orientador profissional: a) explicar o propósito e as expectativas de se utilizar esse instrumento; b) explicar como utilizar e qual a melhor direção e c) pedir para que o orientando traga impresso os resultados obtidos com a sua pesquisa, assim o orientador terá a oportunidade de ajudar o orientando a usufruir melhor de seus dados.

Desde a criação desses programas informáticos muito se especulou a respeito cogitando que os mesmos iriam substituir os orientadores profissionais, o que se tem observado “com os sistemas atuais, há um resultado que aparece adquirido: a interação com os programas informáticos não reduz a procura de contatos pessoais com um conselheiro, bem pelo contrário, aumenta-a” (GUICHARD; HUTEAU, 2001, p.310). Como sugerem as pesquisas já realizadas, o melhor desempenho propõe a utilização conjunta da internet ou de programas da informática com os métodos tradicionais a fim de otimizar o desempenho do orientador profissional ao invés de colocar as duas estratégias de intervenção em situação competitiva. Trata-se de recursos que podem ser integrados às práticas dos orientadores (GUICHARD; HUTEAU, 2001, REILE; HARRIS-BOWLSBEY, 2000, NILES; HARRISBOWLSBEY, 2005). 
Segundo Niles e Harris-Bowlsbey (2005), existem pelo menos três razões que impossibilitam a Orientação Profissional pelo computador sem a presença do orientador. A primeira razão é que ao necessitar de ajuda para a escolha da profissão uma variedade de necessidades deve ser levada em consideração o que não é possível através dos programas. A segunda razão, as pessoas têm diferentes estilos de aprendizagem e personalidade, demandando processos diferentes para cada necessidade. E por último as pesquisas vêm mostrando que o melhor caminho para o planejamento de carreira é a combinação do serviço humano com o do computador.

Contudo é inevitável que muitas pessoas irão utilizar os instrumentos disponíveis na internet sem a preparação ou intervenção de orientador profissional, podendo muitas vezes ter bons resultados na utilização dos mesmos no processo de escolha da sua profissão. Mas nesse caso algumas considerações são importantes para aumentar as oportunidades de um bom aproveitamento, como: a natureza do instrumento (instrumento elaborado para ser de autoajuda), a qualidade do instrumento para fazer as interpretações e finalmente a maturidade profissional do cliente (REILE; HARRIS-BOWLSBEY, 2000).

Assim, dentre as responsabilidades do orientador na Orientação Profissional, Niles e Harris-Bowlsbey (2005) acrescentam que o orientador deverá determinar a prontidão da pessoa para receber a informação do computador e aplicá-la efetivamente; expandir na interpretação de teste e inventários para poder informar ao cliente se o mesmo está tomando a decisão apropriada; identificar valores pessoais que reduzirão as opções fornecidas pelo computador, promover motivação e suporte emocional para manter o trabalho de planejamento de carreira e finalmente, sugerir alternativas criativas que o computador não "sabe".

Para que o orientador profissional alcance os objetivos acima relacionados, algumas competências são necessárias, como: conhecer os vários sistemas de computador e websites, capacidade de diagnosticar as necessidades do orientando, motivar no percurso da orientação, de auxiliar no processamento das informações e a capacidade de direcionar para um plano de ação que possa ter sucesso. Essas competências poderão ser aplicadas em combinação a vários modelos diferentes de orientação profissional e a utilização de programas de computador ou websites, ou seja, em trabalhos individuais, em grupos de orientação profissional ou em salas de aula (NILES; HARRIS-BOWLSBEY, 2005).

Os orientados, por sua vez, têm um papel importante no processo, terão que completar as colocações ou sugestões do orientador, pensando e refletindo sobre seus interesses, engajando-se nas atividades propostas. Alguns orientandos gostariam de respostas rápidas e 
fáceis, outros esperam que os testes lhes concedam as respostas e ainda há os que esperam que o orientador adivinhe o que gostariam de fazer para não arcar com as responsabilidades da sua decisão (NILES; HARRIS-BOWLSBEY, 2005). É fundamental a implicação do jovem no processo de busca de informação profissional, principalmente por ser a busca de informação no banco de dados de acesso muito rápido. No entanto existe o perigo da informação ser tratada superficialmente porque o sujeito pode considerar, erradamente, que deve acompanhar o ritmo do computador e não processar internamente os conteúdos. Por outro lado, para (GUICHARD; HUTEAU, 2001) a busca de informações pela internet dá a possibilidade de criar ferramentas que apresentam duas propriedades pedagógicas: a interação com a informação, que leva o sujeito a perceber onde estão centrados o seu interesse e as maiores dúvidas, e a outra propriedade é a possibilidade de caminhos individualizados na procura da informação, pois a mesma não se apresenta linearmente, mas elaborada em um conjunto de textos, imagens e sons.

A possibilidade da utilização de novos meios tecnológicos, como: telefone, website, email, links com facilidades face a face e os chats abrem novas oportunidades de orientação e informação profissional. Isto significa que as pessoas podem acessar ajuda da forma que seja conveniente e confortável para cada um. Para Watts (2002), todos esses meios tecnológicos poderiam ser considerados não somente como serviços alternativos, mas como uma ampla, flexível e harmoniosa rede de serviços que enriquecem o aprendizado de caminhos disponíveis aos indivíduos.

Segundo o Guidelines for web-based guidance, (ARIADNE, s.d), a internet reúne várias outras vantagens em sua utilização, principalmente por ser um instrumento poderoso de se obter informações, ser também um meio democrático, igualitário, de acesso livre e fácil, de material farto, em comparação a antiga mídia, e de informações rapidamente atualizadas. Entretanto, as desvantagens seriam a dificuldade de controlar as informações quanto à qualidade das mesmas. Os usuários dos sites deveriam desenvolver julgamentos, ou critérios para serem analisados ao acessar as informações.

O primeiro critério é verificar a atualidade do site, com que periodicidade ele é revisado, além de: as informações fornecidas devem conter as fontes, os organizadores da website devem fornecer endereço e/ou outro contato, considerar as variedades sócio-culturais mundiais, estar atento ao propósito ou finalidade do conteúdo, verificar a presença de argumentos razoáveis, justificados, balanceados com pontos de vista alternativos. Para tanto, o usuário deve desenvolver habilidade cognitiva para lidar com a informação encontrada nas webs para selecionar, organizar e sintetizar informações qualificadas. 
Um usuário interessado em planejar a carreira deveria tentar encontrar webs que tenham suportes em diversas áreas. Usuários diferentes têm necessidades variadas. Se o usuário está em um estágio mais recente do processo de planejamento de carreira então seria interessante procurar por sites que suportem o desenvolvimento das habilidades mencionadas acima, no processo de se tornar um aprendiz independente.(ARIADNE, s.d).

Os tipos de serviços oferecidos e a forma que as informações são transmitidas para o usuário na internet variam entre dados gerais e amplos até os mais específicos e detalhados. Os serviços incluídos são: fornecer informações em tópicos específicos, informação e treinamento nas oportunidades de emprego, aconselhamento de carreira e evolução dos objetivos. No guia Ariadne são citadas também algumas habilidades pessoais dos usuários que facilitariam e otimizariam o alcance de seus objetivos. O primeiro ponto é quanto ao nível de frustração do usuário no caso de ocorrerem problemas em seu manuseio, um outro ponto é a habilidade na utilização da internet e familiaridade com a comunicação da rede. E finalmente, ter condições de se expressar de forma objetiva e concisa através da escrita e da leitura.

O fato mais complicado na Orientação Profissional apenas por meio da rede é que não se encontra o orientando pessoalmente e vários aspectos não serão conhecidos, entretanto, um outro tipo de relação se constrói e conseqüentemente diminui o impacto da comunicação face a face. O aumento da demanda desse serviço mostra os aspectos positivos, em que o usuário pode determinar a hora da procura, os caminhos que prefere percorrer, o limite de tempo desejado além de ser mais uma opção para aqueles que se sentem desconfortáveis com as orientações pessoalmente (SAMPSON; LUMSDEN, 2000).

Para Reile e Harris-Bowlsbey (2000), a maior desvantagem da utilização apenas da internet na Orientação Profissional é a redução do contato pessoal entre os estudantes e os orientadores. Assim se perde o poder das relações pessoais, dos vínculos que representam um valor inestimável na experiência educacional como especificamente na ajuda para a escolha profissional. Uma outra desvantagem seria quanto aos diferentes estilos de aprendizagem do estudante os que: aprendem lendo, na experiência pessoal, na utilização de recursos áudiovisuais e outros nas interações pessoais. E finalmente os autores citam como desvantagem o nível de motivação do estudante, alguns necessitando do contato semanal do orientador para proporcionar motivação na resolução dos obstáculos e seguir rumo a seus objetivos.

As novas tecnologias oferecem novas possibilidades de Orientação Profissional de maneira mais eficiente e fácil, mas com certeza diferentes dos moldes tradicionais. A tarefa do orientador é promover a escolha profissional de modo autônomo. Quando as pessoas podem ter esse apoio na web, analisando suas qualidades e características, relacionando-as 
com as informações acerca das possibilidades de educação, o trabalho do orientador adquire características pedagógicas (ARIADNE, s.d). A proposta da Orientação Profissional se amplia ao valorizar a importância da ação educativa com os adolescentes em processo de escolha profissional, no sentido de formar um homem integrado com seu mundo, promovendo uma reflexão que enriquece a si e ao meio.

A web cada vez mais vem se tornando indispensável parte do nosso dia-dia, mudança que já modificou a Orientação Profissional e os serviços de busca de empregos. A questão atual é como os orientadores profissionais deverão adotar essas tecnologias e as implicações oriundas das novidades (REILE; HARRIS-BOWLSBEY, 2000).

O desafio da nova tecnologia não está em fazer as mesmas coisas de uma nova maneira, mas em desenvolver uma prática à luz das novas possibilidades. Para tanto, teorias terão que surgir considerando os novos contextos e oferecer perspectivas diferentes. Um dos desafios que merece discussão é o referente às questões éticas do atendimento de Orientação Profissional na web. Um dos aspectos mais importantes refere-se aos conteúdos confidenciais, a todas as informações sobre o usuário: quem é responsável por esses dados, qual é a proteção contra intrusos para a manutenção da integridade dos usuários? Além de outros aspectos como os referentes à linguagem utilizada, o respeito à diferença cultural e a acessibilidade dos sites a todas as pessoas.

Segundo Sampson e Lumsden (2000), algumas questões éticas deveriam ser tratadas com atenção. Pois as pessoas que acessam os sites estão em um momento de tomar decisões importantes sobre as profissões e irão utilizar o que aprenderam com as informações encontradas nos mesmos. Quanto às informações disponibilizadas nos sites um cuidado importante é com a boa qualidade e validade, além de conter de forma clara as referências (fontes) e datas dos instrumentos e demais informações.

Outras questões éticas foram desenvolvidas pelos autores, como: na administração de testes pela internet é importante um cuidado com a validade dos mesmos para serem aplicados em condições adversas, o controle de padronização fica seriamente comprometido demandando o desenvolvimento de testes específicos para a utilização pela internet. Um outro cuidado, na utilização da internet feita online com a orientação do orientador profissional sem o contato pessoal, refere-se a informações sobre as condições socioeconômicas do orientando, como de outros dados importantes que podem influenciar de alguma forma na escolha da profissão. Um outro ponto levantado é quanto ao acesso à internet não ser eqüitativo, uma vez que as pessoas com limitações financeiras têm maiores dificuldades de acesso. Além de o sigilo e a privacidade das informações fornecidas pelos orientados serem ainda questionáveis, 
é importante que o usuário do site esteja ciente dos riscos inerentes a esse tipo de serviço (SAMPSON E LUMSDEN, 2000).

Muitas são as dúvidas e ainda se está longe de respostas. O fato da qualidade das webs variarem maciçamente nos remete a como elaborar controles sem interferir na liberdade de comunicação. Outra discussão importante alude a quem ficaria com essa função, profissionais, usuários ou governo? Os guias mais relevantes utilizados no Canadá e nos Estados Unidos são elaborados por profissionais ou setores independentes, em nível nacional; na Europa são elaborados em nível multinacional. Entretanto, por ser a internet de acesso global, Watts (2002) sugere serem realizados acordos em nível global que considerem as possibilidades e a conveniência. Segundo o guia Ariadne (s.d), a solução atual seria a transparência, ser honesto com os usuários e informar que todo o possível será feito para protegê-los. Mas trabalhando por meio da web existem limites e territórios desconhecidos que, ao se depararem com as questões éticas, podem não ser identificados.

Uma outra reflexão proposta por Sampson (2002) adverte que é fácil concluir que a responsabilidade em manter a qualidade e ética nos serviços oferecidos e disponibilizados na web seja dos seus mentores e mantenedores. Entretanto, o autor sugere que uma análise mais cuidadosa revela que essa responsabilidade é função de um sistema de múltiplos participantes, como: mentores, mantenedores, usuários, políticos, pesquisadores e avaliadores (fontes de recursos públicos e privados). Será necessário um trabalho conjunto e ao mesmo tempo individual para desenvolver novos caminhos e possibilidades. Pois enquanto a tecnologia está sempre mudando, as necessidades básicas do indivíduo relacionado ao desenvolvimento de carreira serão constantes.

A discussão de temas sobre a ética na utilização dos vários serviços de Orientação Profissional via internet é importante no sentido de poder proporcionar o crescimento e desenvolvimento desse serviço baseando-se em pesquisas, treinamentos e revisões teóricas que tragam embasamento e credibilidade.

Para Watts (2002), as TIC’s na Orientação Profissional podem ser vistas de três perspctivas: (1) como uma ferramenta, (2) uma alternativa ou (3) como um agente de mudança. As políticas tendiam a vê-las freqüentemente como uma ferramenta ou uma alternativa, no sentido de acrescentar os serviços existentes ou substituí-los. Entretanto, toda a expansão e crescimento sugerem que o potencial da TIC é como um agente de mudança, que paralelamente vem transformando muitos outros setores amplamente e agora desafiando as políticas públicas. 
Muitos aspectos dessa questão deverão ser refletidos à procura de soluções cabíveis. Muito ainda há que se caminhar no Brasil no sentido de melhorar a qualidade, acesso, criação e utilização de sistemas com tecnologia nacional apropriados para a realidade brasileira. Atualmente a legislação que regulamenta a utilização da internet na área da Psicologia é o Conselho Federal de Psicologia pela Resolução No 003/2000 de 25 de setembro de 2000. No Art. 5º são reconhecidos os serviços psicológicos mediados por computador, desde que não psicoterapêuticos, tais como orientação psicológica, orientação profissional, dentre outros, como a utilização de testes informatizados devidamente validados, utilização de softwares informativos e educativos com resposta automatizada, e outros, desde que não firam o disposto no Código de Ética Profissional do Psicólogo.

No Brasil vem crescendo gradativamente esse tipo de oferta. Nas informações profissionais virtuais várias são as modalidades. No site www.sitedebusca.com.br foram selecionados 45 sites diferentes de orientação e informação profissional. Outro site bastante

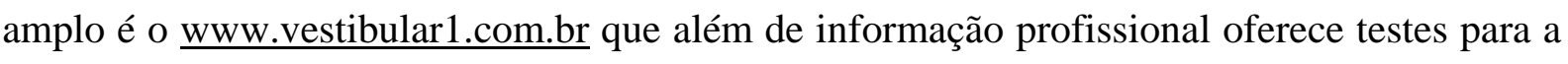
escolha da profissão e serviços diversos de auxílio ao vestibulando, disponibilizando outros 43 sites de informação profissional. Nestes não foram contabilizados os sites das universidades que oferecem informações sobre seus cursos.

Os diversos programas de Informação Profissional, no Brasil, são oferecidos pela internet em sintonia com o avanço das novas tecnologias. São sites com informações sobre profissões, vestibulares e cursos (SPACAQUERCHE, 2005). Os serviços online de qualidade, em geral, são vinculados a projetos de pesquisas e a Programas de Pós-graduação (MELO-SILVA; LASSANCE; SOARES, 2004). Um deles é oferecido pelo Laboratório de Informação e Orientação Profissional (LIOP) da Universidade Federal de Santa Catarina (UFSC). Terêncio; Soares (2003) em um estudo que avalia o programa salientam que apesar de serem otimistas quanto ao uso da internet em Orientação Profissional, consideram que a mesma não substitui a qualidade do contato presencial. Outro estudo desenvolvido por Spacaquerche (2005) analisa a experiência de um programa de Orientação Profissional mediado por computador em uma parceria da Pontifícia Universidade Católica de São Paulo (PUC-SP), por meio da Coordenação Geral de Especialização, Aperfeiçoamento e Extensão (COGEAE), com o Banco do Brasil, visando o atendimento a adolescentes trabalhadores. A Universidade de Brasília (SIEBIGER, s.d) apresenta uma proposta de Orientação e Informação Profissional oferecida via internet, vinculado à Associação Brasileira de Educação à Distância (ABEaD). Propõe a constituição de um site com grupo de discussão, 
banco de pesquisas entre outras atividades. Esses são alguns dos exemplos de uma ampla gama de opções disponíveis ao adolescente, no contexto brasileiro.

Entretanto, o que mais preocupa os autores de estudos internacionais refere-se à qualidade dos sites na área de Orientação Profissional que deixa muito a desejar. Mesmo os sites subsidiados ou financiados por órgãos públicos não seguem um padrão de qualidade e objetivos claros (ESBROECK, 2002; NILES; HARRIS-BOWLSBEY, 2005; SAVICKAS; ESBROECK; HERR, 2005; WATTS, 2002). Esta deveria ser também uma preocupação dos orientadores profissionais no Brasil, no sentido de desenvolver pesquisas na área e de aplicálas na prática da utilização da internet no dia a dia dos adolescentes.

De acordo com os estudos e revisões de Savard et.al (2002), a literatura parece mostrar que o cliente está experimentando dificuldade em localizar informações relevantes e utilizálas efetivamente no processo de escolha profissional. A maioria dos clientes encontra constrangimentos de ordem afetiva, cognitiva ou técnica quando interagem com a informação e a nova tecnologia. O mesmo autor sugere que alguns questionamentos sejam realizados a fim de prosseguir a análise, tais como: quais perspectivas deveria a intervenção considerar frente à informação e ao processo de escolha profissional? Como podem os recursos humanos e físicos ser utilizados para otimizar a necessidade de informações associada com os diferentes estágios da vida das pessoas?

Os autores Isaacson e Brown ${ }^{5}$ (1997 apud SAVARD et al., 2002, p. 176) expressam um ponto de vista diferente quando identificam os sistemas de computador usados como suporte no desenvolvimento de informação de carreira e ocupação profissional. Estes autores avaliaram a contribuição da tecnologia nos computadores em relação ao autoconhecimento, informações sobre o mundo do trabalho, as várias opções frente à escolha, escolha da profissão e o desenvolvimento de um plano de ação. Em relação ao autoconhecimento eles acreditam que o computador pode trazer uma limitada contribuição. No ponto de vista deles, as características psicológicas específicas do indivíduo, as circunstâncias únicas e a interação com o meio são componentes que não podem ser considerados pelos programas de computador. Por outro lado, os autores acreditam que o computador oferece duas grandes vantagens: um bom conhecimento do mundo do trabalho de modo atualizado e adaptável aos diferentes níveis de informação de acordo com as necessidades específica; e a abundância e rapidez em adquirir a informação, que são as condições disponíveis no computador.

\footnotetext{
${ }^{5}$ ISAACSON, L. E.; BROWN, D. Career information, career counseling, and career development. Boston: Allyn and Bacon, 1997.
} 
Entretanto, salientam que é fundamental ter o orientador para certificar como será a utilização da informação pelo orientando.

Neste sentido, Sampson (1999), afirma a importância de integrar a utilização de programas de Orientação Profissional virtuais com os serviços presenciais como os oferecidos nos Centros de Orientação Profissional. Assim, o referido autor destaca que a utilização da informação profissional é parte do aprendizado; baseia-se no seu próprio modelo sobre os seis degraus do processo para efetivar a utilização da informação. O modelo consiste primeiro na necessidade de reconhecer que existe um problema e que é preciso informação, segundo em selecionar a informação que atende as necessidades, terceiro em decidir como usá-la, quarto em utilizar as pesquisas das informações, quinto em avaliar se as necessidades foram sanadas, e sexto procurar ajuda ou outros recursos necessários até que o problema esteja resolvido.

Ainda segundo Sampson (1999), os indivíduos não estão no mesmo estágio no processo de escolha profissional. Ele acredita que os mais adiantados no processo de escolha podem utilizar os serviços do computador de modo mais independente, outros irão requerer mínima assistência e uma proporção de indivíduos irá requerer um suporte maior para usufruírem da informação.

Ao considerarmos que a personalidade do indivíduo e até o seu estilo em apreender as informações podem influenciar nos diferentes tipos de ajuda indicados pode-se recorrer ao exemplo citado por Savard et. al. (2002) referente à tipologia de Holland, que relata os diferentes tipos: o tipo investigativo que prefere utilizar os serviços no computador, o tipo social caracterizado por atributos como a necessidade de interação, preferem resolver seus problemas nas relações vivenciais, presenciais com os outros. Ao que parece as novas tecnologias trouxeram várias contribuições e possibilidades de utilização que, entretanto, não podem ser generalizadas para todos como adequadas (SAVARD et. el., 2002).

Savard et.al.(2002) cita vários estudos para demonstrar a importância da qualidade da relação orientando-orientador na construção da identidade profissional. O conceito que as pessoas têm sobre si próprias deriva do modo como as mesmas acreditam que os outros a vêem. Dentre os estudos Guédon e Savard ${ }^{6}$ (2000 apud SAVARDet.al., 2002), os autores concluíram que os indivíduos sozinhos na frente da tela do computador acessando e interpretando os resultados de sua busca se confrontam com nada mais que suas próprias percepções. Deste modo, não têm o beneficio das percepções de outra pessoa, que possam ajudá-los a qualificar e até modificar suas concepções, inclusive correm o risco de não

\footnotetext{
${ }^{6}$ GUÉDON, M. C.; SAVARD,R. Tests à l’appui: Pour une intervention intégrée de la psychométrie en counseling d'orientation. Sainte-Foy, 2000.
} 
fazerem as escolhas apropriadas. E os autores ainda consideram que as mudanças na autoestima podem alterar as avaliações das pessoas e com isso suas interpretações oscilarem num otimismo irrealista até de extremo cuidado.

Com certeza todos os autores reconhecem o crescimento na importância da tecnologia do computador e dos benefícios que pode oferecer aos clientes engajados no processo de busca de informação. Entretanto, é essencial como sugere Savard et.al. (2002), que esse recurso seja utilizado como parte de um suporte que possa orientar o cliente a utilizar um bom serviço de computador, mostrar ao cliente as possibilidades e limitações do serviço selecionado, a importância de se refletir sobre as informações coletadas e impedir a utilização das informações para comprometer a integridade dos planos individuais. Esse suporte só poderá ser definido a partir das características e circunstâncias únicas de cada cliente e dos recursos humanos e técnicos envolvidos no processo. Focalizar a atenção no indivíduo remete à avaliação da pessoa, de seu funcionamento psicológico, em seus traços e características.

As várias dúvidas permanecem: o que pode se dizer com certeza sobre as intervenções através do computador? Os resultados são realmente positivos? Todos têm o necessário conhecimento para auxiliar e aconselhar os seus orientados? Quais as condições do Brasil na implantação e utilização das novas tecnologias? Para Esbroeck (2002), muitos bons trabalhos vêm sendo desenvolvidos nesse campo, mas ainda é cedo e muito mais trabalhos serão necessários nesse campo de investigação. Principalmente porque a utilização da TIC tem criado novos desafios e problemas para todos que trabalham no campo da Orientação Profissional e alguns orientadores estão preparados, porém outros ainda não, para o uso eficaz das novas tecnologias.

Com relação aos jovens brasileiros em situação de escolha da carreira, sabe-se que eles estão habilitados para lidar com o mundo digital. Porém, o questionamento é se eles estão utilizando a internet como recurso para obterem informações sobre as carreiras e as profissões universitárias de forma a auxiliar no amadurecimento tendo em vista o processo de tomada de decisão acerca da carreira profissional.

\subsection{Justificativa do estudo}

Na prática com os adolescentes atendidos pelo Serviço de Orientação Profissional (SOP/ CPA/ FFCLRP-USP) tem se observado que os adolescentes utilizam muito as tecnologias de informação como a internet para conversações e para a busca de informações. 
Tendo em vista que em processos de Orientação Profissional a informação profissional é útil e necessária, como afirmado anteriormente, o interesse nesse estudo é compreender um pouco mais qual tem sido o envolvimento dos jovens com a busca de informações. Pretende-se investigar o nível de informação profissional e de maturidade para a escolha da carreira, em adolescentes antes e depois da intervenção em Orientação Profissional.

Considerando a informação como parte do processo de Orientação Profissional e necessária tanto quanto a maturidade para a tomada de decisão, esta pesquisa investiga processos grupais de Orientação Profissional na abordagem de Pichon-Rivière. Para tanto, serão focalizados no estudo os vetores comunicação e aprendizagem, para examinar como os adolescentes, participantes deste estudo, lidam com as informações e, conseqüentemente, trocam idéias e aprendem a tomar decisões profissionais.

Neste sentido, o presente estudo se justifica pela relevância da produção de conhecimento sistematizado sobre informação, no processo de Orientação Profissional. A importância da compreensão sobre a informação profissional foi salientada na literatura internacional. FOUAD (1994), por exemplo, em seu estudo de revisão, fez recomendações para pesquisas futuras.

Os estudiosos devem examinar como o processamento de informação ocorre na tomada de decisão vocacional. A informação para a carreira está mais prontamente disponível do que antes nas bibliotecas e através do correio eletrônico, embora pouco se saiba sobre como melhor ajudar os clientes a processar informação (FOUAD, 1994, p. 160-161).

No cenário atual brasileiro, esforços nessa linha investigativa se justificam em decorrência de variáveis supostamente associadas a esse contexto de estudo:

(1) há pouca tradição de pesquisas no domínio da informação profissional;

(2) o uso da internet, e outros meios de comunicação, por jovens, ocorreu, sobretudo, na última década;

(3) há necessidade de informação sobre o acesso à carreira universitária devido a mudanças, implementadas ou em andamento, nas formas de acesso à carreira universitária tais como: o Exame Nacional do Ensino Médio (ENEM), o Programa Universidade para todos (ProUNI), Sistema de Cotas e outros processos seletivos. Finalmente, este estudo foi delineado com base no argumento a seguir.

Estudos que descrevam os serviços são importantes, mas além de descrever é necessário avaliar técnicas, instrumentos, processos e resultados. Avaliar a prática do interventor passa por questões metodológicas complexas, pela necessidade de administrar egos, limites e dificuldades, entretanto, abre 
caminhos, possibilidades e poderá contribuir para a consolidação de uma área, tradicionalmente pouco valorizada em nosso País, nas áreas da Psicologia, da Educação e da Sociologia (Melo-Silva; Jacquemin, 2001, p. 237).

Feitas as considerações anteriores, cumpre destacar que este estudo se insere na linha de pesquisa "Orientação profissional, educação e desenvolvimento de carreira: diagnóstico e intervenção”, que focaliza a Avaliação em Orientação Profissional (MELO-SILVA; JACQUEMIN, 2001, MELO-SILVA; ALMEIDA; LOOSLI; FRAGA, 2004, MELO-SILVA, 2005). A avaliação da intervenção psicológica em orientação profissional é realizada sob três perspectivas: (1) avaliação da pessoa, (2) avaliação de problemas e problemáticas, e (3) avaliação de processos e resultados de procedimentos de intervenção. Especificamente o presente estudo focalizará a avaliação do serviço.

As intervenções de carreira, segundo Spokane (2004), podem ser classificadas em cinco níveis, dependendo da natureza das estratégias implementadas, dos recursos utilizados, do tempo e do nível de envolvimento do cliente e do psicólogo. A saber, Nível I: oferta da informação - folhetos, guias, vídeos, biblioteca; Nível II: atividades auto-administradas, programas mediados por computador, abordagens experienciais do trabalho; Nível III: modos de tratamento alternativo, tipo workshop, seminários, grupos de turma, cursos breves ou semestrais; Nível IV: consulta psicológica em grupo; e Nível V: consulta psicológica individual. Os Níveis I e II não requerem o envolvimento do psicólogo, no nível III o psicólogo pode colaborar indiretamente, enquanto que nos Níveis IV e V há envolvimento máximo do psicólogo.

Este estudo, portanto, se insere no contexto da avaliação da pessoa, ao avaliar o grau de maturidade e de informação profissional em um grupo de jovens e, sobretudo, de processos e resultados em intervenções de natureza psicológica (Nível IV), do tipo Aconselhamento de Carreira (Career Counseling) em interface com o Aconselhamento Pessoal (Personal Counseling), que visam ajudar cada pessoa a implementar decisões eficazes de carreira, ou seja "escolher” ou definir o futuro, focalizando o Nível I: a oferta e uso da Informação por parte dos jovens que participaram de um procedimento de intervenção em Orientação Profissional grupal. 


\section{OBJETIVOS}

\subsection{Objetivo Geral}

- Avaliar um procedimento de intervenção desenvolvido com adolescentes, de ambos os sexos, em processo de Orientação Profissional em grupo.

\subsection{Objetivos Específicos}

- Avaliar a informação para a escolha profissional em adolescentes participantes de processos grupais de Orientação Profissional, em função do momento da intervenção (pré e pós) e do sexo.

- Avaliar a maturidade para a escolha da carreira em adolescentes participantes de processos grupais de Orientação Profissional, em função do momento da intervenção (pré e pós) e do sexo.

- Avaliar o processo grupal, em função da comunicação e da aprendizagem. 


\section{MÉTODO}

\subsection{Participantes}

Os participantes deste estudo são adolescentes provenientes de escolas de Ensino Médio e cursos pré-vestibulares, público e/ou privado, de ambos os sexos, com idade entre 15 e 19 anos que foram atendidos no Serviço de Orientação Profissional (SOP) do Centro de Pesquisa e Psicologia Aplicada (CPA), da Faculdade de Filosofia, Ciências e Letras de Ribeirão Preto da Universidade de São Paulo (FFCLR-USP). Estes adolescentes procuram espontaneamente o Serviço de Orientação Profissional.

A amostra inicial deste estudo foi constituída por 40 adolescentes. Para a composição dos grupos foram consideradas as variáveis: nível de maturidade para a escolha profissional e sexo (masculino e feminino). No tópico sobre o procedimento de coleta de dados descreve-se em maiores detalhes a composição dos grupos, uma vez que as decisões sobre a seleção da amostra dependeram do funcionamento do SOP.

Em princípio, houve a intenção de controlar a variável maturidade para fins tanto da intervenção quanto da avaliação, considerando que os adolescentes com maturidade para a escolha profissional, classificados em Médio Superior e/ou Superior não apresentariam as mesmas necessidades para efetuar a escolha profissional se comparados aos jovens com maturidade Inferior. Porém, para a composição dos grupos a partir de pessoas que procuraram espontaneamente o SOP foi possível montar grupos que se diferenciavam muito pouco em termos de maturidade profissional.

A classificação da maturidade para a escolha profissional definiu a pertença ao grupo A ou B, com vinte integrantes em cada grupo. O grupo A foi composto por integrantes com maturidade abaixo da média (Muito Inferior e Inferior) e o grupo B com membros avaliados em função da maturidade na média (Médio Inferior e Médio), conforme resultados obtidos na Escala de Maturidade Profissional (EMEP), de Neiva (1999).

Ambos os grupos foram organizados com 50\% dos integrantes de cada sexo. A decisão de realizar o estudo com ambos os sexos, em equilíbrio em cada grupo, visa promover maior troca de informações entre os integrantes considerando a questão do sexo/gênero, apesar de pesquisas do Serviço mostrarem uma maior procura pelo sexo feminino (SANTOS; MELO-SILVA; JUNTA, 1997). A demanda de jovens do sexo feminino se mantém, 
conforme registro dos atendimentos realizados no SOP nos últimos dois anos. Em 2005, $66.7 \%$ da procura foi do sexo feminino e $33.3 \%$ do sexo masculino e no ano de 2006, $66.3 \%$ do sexo feminino e $34.7 \%$ do sexo masculino. Os grupos contaram inicialmente com $50 \%$ de cada sexo, experiência diferente dos grupos habituais do Serviço que são formados com percentual mais baixo do sexo masculino, na média 30\% (AZEVEDO, R. N.; ESBROGEO, M.C; MELO-SILVA, L. L., 2007).

As variáveis: faixa etária, procedência e série escolar não foram controladas. A procedência escolar seria desejável, porém de acordo com a demanda ao Serviço, não foi possível organizar cada grupo com 50\% de estudantes oriundos de escolas públicas. O SOP em 2005 teve 26.3\% de alunos provenientes de escolas públicas e 73.7\% de alunos provenientes de escola particular e em 2006 teve 10.5\% de alunos de escola pública e 89.5\% de alunos de escolas particulares. O predomínio de estudantes da escola particular provavelmente se deve ao fato da população oriunda das escolas particulares ter mais oportunidades de realizar os exames seletivos na universidade. Este dado circunscreve a amostra dentro de uma população com condições socioeconômicas e educacionais que facilitam o ingresso e a permanência em cursos de nível superior.

Em cada grupo a idade e as séries do Ensino Médio variam um pouco. Segundo MeloSilva e Jacquemin (2001) os questionamentos, comprometimento e o nível de ansiedade alteram em função de peculiaridades individuais e da série em que o jovem estuda. A pressão externa decorrente do ambiente e a interna da auto-exigência, para a tomada de decisão, se apresentam de formas e intensidade diferentes. As pressões se configuram de forma mais branda na $1^{\mathrm{a}}$ série do Ensino Médio e gradativamente se intensificam. A heterogeneidade nestas variáveis foi considerada adequada para a composição da amostra constituída de adolescentes que buscaram espontaneamente o SOP.

Assim, quanto mais heterogênea for a composição de um grupo, segundo PichonRiviére, mais a comunicação pode fluir e ser produtiva dentro da diversidade de visões e pontos de vista de cada integrante. O grupo adquire mais homogeneidade na resolução da tarefa, uma vez que tem por finalidade aprender a pensar nas resoluções das dificuldades criadas no próprio espaço grupal (DELGADO; GUTIÉRREZ, 1995). Neste estudo, a tarefa visou alcançar a finalidade de escolha da carreira, na definição do futuro profissional e a assunção de compromissos com um projeto de vida. O número da amostra foi definido em função da natureza do estudo, avaliação da intervenção, com dados também qualitativos. 


\subsection{Instrumentos}

Para a obtenção dos dados foram utilizados três instrumentos, a saber: (1) o Questionário de Informação Profissional (QIP): o que os adolescentes sabem sobre profissões e carreiras?; (2) a Escala de Maturidade para a Escolha Profissional (EMEP) - (NEIVA, 1999); (3) os registros das sessões em grupos operativos de Orientação Profissional do SOP FFCLRP - USP, descritos a seguir.

\subsubsection{Questionário de Informação Profissional (QIP)}

Objetivando verificar se os adolescentes estão buscando e tendo acesso às informações sobre profissões e carreiras um questionário foi elaborado pela pesquisadora e pela orientadora Lucy Leal Melo-Silva, para fins desta pesquisa. O instrumento, intitulado “Questionário sobre Informação Profissional (QIP): o que os adolescentes sabem sobre profissões e carreiras?” (Apêndice A), foi preparado com base em Günther (1999), contendo perguntas abertas e fechadas.

Para Günther “perguntas abertas servem no início da entrevista para estabelecer um clima receptivo entre pesquisador e respondente, servem, no fim do levantamento, para capturar justamente aquelas opiniões não cobertas pelos itens fechados” (GÜNTHER, 1999, p.243). Nas perguntas mais pessoais e sensíveis ao entrevistado é regra, segundo o mesmo autor, utilizar perguntas abertas. Em algumas perguntas fechadas optou-se por propor a resposta num formato de escala Likert, por ser a mais utilizada nas Ciências Sociais, especialmente em levantamentos de atitudes e opiniões. Nesse instrumento proposto (QIP), o uso desse formato de resposta em alguns itens resultou numa tarefa na qual se solicita ao respondente que avalie como vem sendo realizada a busca de informações acerca das profissões numa escala de cinco alternativas: nunca, raramente, às vezes, freqüentemente e sempre. Além disso, foi inserido um espaço para comentários em todas as questões fechadas.

Inicialmente o adolescente é questionado sobre o fato de se sentir suficientemente informado sobre profissões e se a informação pode ajudá-lo na tomada de decisão. Em seguida, questiona-se sobre os recursos ou instrumentos que os adolescentes estão utilizando para buscar informações sobre as carreiras. Para especificar acerca do uso da internet, indagase: como, onde, com qual objetivo e qual a freqüência da utilização desse recurso técnico. As questões seguintes abordam a informação como instrumento na escolha profissional. 
Assim, o próximo item, averigua o quanto o adolescente está informado sobre o acesso à Universidade: o vestibular, o Exame Nacional do Ensino Médio (ENEM), o Sistema de Cotas Universitárias, o Programa Universidade para todos (ProUni) e outros processos seletivos. A inscrição para o vestibular e a isenção de taxa para esse processo, a relação candidato/ vaga e as oportunidades de trabalho no Brasil são abordadas em outro item. A seguir, a pergunta é sobre a qualidade da informação profissional acessada (que proveito tem obtido com as informações e se são necessárias outras informações). A última pergunta é sobre as expectativas em relação ao futuro e ao projeto de vida do adolescente. No final foi inserido um item sobre avaliação da qualidade do questionário proposto, bem como, a identificação do respondente.

Para manter o interesse do entrevistado em responder ao questionário, ele foi elaborado com o intuito de reduzir o custo da tarefa, facilitando o preenchimento das respostas e eliminando a possibilidade de embaraço. Na estruturação do questionário, as perguntas começaram do mais geral para o mais específico, do menos pessoal para o mais pessoal, seguindo-se uma ordem lógica. Assim, a seção de identificação (nome, idade...), foi colocada no final do questionário, bem como as questões referentes à decisão profissional. E a primeira pergunta, “... você acredita que os adolescentes estão suficientemente informados sobre profissões?”, parte do genérico para o pessoal (segunda pergunta).

Para a preparação do questionário contou-se com a análise prévia de seu formato e de seu conteúdo pelos participantes do grupo de estudos do Centro de Pesquisas em Psicodiagnóstico da FFCLRP - USP e dos psicólogos-estagiários do SOP/ FFCLRP - USP. Dessa forma, avalia-se que o QIP passou por um processo inicial de julgamento de avaliadores externos que examinaram sua adequação e pertinência aos objetivos pretendidos, recebendo validação de conteúdo por juízes da área, além da validade aparente pensada inicialmente por seus autores, oferecendo suporte técnico a esse instrumento ora proposto. Além disso, o instrumento foi aplicado nos adolescentes atendidos no SOP (Serviço de Orientação Profissional), nos anos de 2005 e 2006, como estudo piloto para verificar se as perguntas foram adequadamente compreendidas pelos adolescentes. Os dados desse estudo piloto foram analisados e serviram de base para a elaboração do questionário para o presente estudo (ESBROGEO, M.C; MELO-SILVA, L. L, 2007). O QIP foi aplicado no início e ao final do processo de Orientação Profissional em grupo, assim como a EMEP. 


\subsubsection{A Escala de Maturidade para Escolha Profissional (EMEP).}

Objetivando avaliar o nível de maturidade para a escolha profissional dos participantes do presente estudo foi utilizada a Escala de Maturidade para a Escolha Profissional (EMEP) de Neiva (1999), comercializada pela Editora Vetor, como medida de pré e pós intervenção.

A maturidade para a escolha profissional é compreendida por Neiva (1999), com base nas idéias de Super e Crites que consideram que: “para atingir a maturidade para a escolha de uma profissão, é necessário o desenvolvimento de certas atitudes e aquisição de determinados conhecimentos” (NEIVA, 1999). O modelo de maturidade para a escolha, proposto por Neiva (1998, 1999), é composto de duas dimensões: Atitudes e Conhecimentos. A primeira dimensão - Atitudes - contém três subdimensões:

- Determinação para a escolha profissional: avalia o quanto o indivíduo está definido com relação a sua escolha vocacional;

- Responsabilidade para a escolha profissional: avalia quanto o indivíduo se responsabiliza por sua escolha profissional e empreende ações para efetivar uma decisão;

- Independência na escolha profissional: avalia quanto o indivíduo está tomando esta decisão de forma independente, sem influência de outras pessoas.

A segunda dimensão - Conhecimentos - está composta por duas dimensões:

- Autoconhecimento: avalia quanto o indivíduo conhece suas características pessoais, interesses, habilidades, valores dentre outros; e

- Conhecimento da realidade educativa e socioprofissional: avalia o quanto o indivíduo conhece a realidade escolar e de trabalho, como profissões, mercado de trabalho, níveis salariais, instituições educativas, qualidade de ensino, exigências dentre outros.

A EMEP (NEIVA, 1998) foi construída em espanhol sendo obtida sua validade e fidedignidade em um estudo com 600 alunos de uma escola no México, os alunos cursavam o Ensino Médio. Da forma original foram mantidos 40 itens, traduzidos com todos os cuidados a fim de preservar o sentido original, e outros seis novos itens foram acrescentados. As subescalas Determinação, Responsabilidade e Independência foram inspiradas na Escala de atitudes do CMI elaborado por Crites em 1965.

Para o estudo de validade e fidedignidade da EMEP utilizou-se uma amostra de 506 estudantes do sexo masculino e feminino, de 13 a 19 anos, cursando o Ensino Médio de uma escola particular da cidade de São Paulo. A validade foi testada através do método de análise fatorial e também pela análise da sensibilidade discriminativa das sub-escalas e das variáveis, 
escolaridade e idade. A fidedignidade foi avaliada através do coeficiente de consistência interna (alfa de Cronbach). Os itens da EMEP apresentaram um bom grau de homogeneidade e os resultados indicaram ser a escala válida e precisa. A única limitação quanto à validade foi encontrada na sub-escala Independência, embora seu nível de consistência interna seja bom. A EMEP parece ser um instrumento útil para a medida da maturidade para a escolha profissional de adolescentes no contexto brasileiro (NEIVA, 1998).

Segundo Neiva (1999), a EMEP tem como objetivo avaliar o nível de maturidade para a escolha profissional de alunos do Ensino Médio e detectar os aspectos mais e menos desenvolvidos. A escala é composta de cinco sub-escalas, mencionadas anteriormente: Determinação, Responsabilidade, Independência, Autoconhecimento e o Conhecimento da realidade educativa e socioprofissional. Nos resultados a cada sub-escala são dados a pontuação bruta, o percentil correspondente e sua classificação em Muito Inferior, Inferior, Médio Inferior, Médio, Médio Superior, Superior e Muito Superior. O nível de maturidade do Muito Inferior para o Muito Superior indica que a pessoa necessita, em maior grau, desenvolver atitudes e adquirir conhecimentos importantes para a tomada da decisão profissional. Cumpre destacar que, cada indivíduo é único e que em cada uma das sub-escalas ele pode apresentar uma classificação diferente, inclusive da classificação total.

Para a autora, a EMEP pode ser utilizada nas áreas: clínica, escolar e de pesquisa, dependendo da finalidade da utilização e a aplicação pode ser individual ou em grupo. A população adequada para a utilização da EMEP são os indivíduos cursando o Ensino Médio ou que já o concluíram e estão em situação de tomada de decisão acerca da futura profissão. O tempo de aplicação ocorre em torno de 15 a 30 minutos, entretanto, caso seja necessário mais tempo não existe restrição.

A escala é composta de uma folha do teste que contém um quadro para ser preenchido com os dados pessoais do sujeito, a data e a forma de aplicação da escala (individual ou grupal, pré ou pós Orientação Profissional), o quadro dos resultados para ser preenchido pelo orientador posteriormente e as instruções do teste. No verso da folha estão as 45 perguntas e os espaços para as respostas. Dentre as perguntas 23 são positivas, indicadores de maturidade e 22 são negativas, indicando imaturidade. A coluna de resposta é do tipo Likert de cinco pontos: (1) nunca, (2) raramente, (3) às vezes, (4) freqüentemente e (5) sempre, em que o indivíduo tem a tarefa de avaliar a freqüência em que atua ou pensa, segundo a forma indicada em cada pergunta. $\mathrm{Na}$ apuração dos resultados é necessário fazer a conversão dos itens negativos.

Pelo exposto anteriormente, a referida escala foi utilizada como instrumento pré e pósintervenção, tendo sido aplicada no início e no final do processo de Orientação Profissional 
em Grupo Operativo. Neiva (2000, p.32) “comprova que a EMEP detecta a evolução do orientando ao longo do processo de orientação profissional e que pode, portanto, ser utilizada como instrumento de avaliação desta evolução”. A comparação dos resultados pré e pósorientação profissional permite detectar as dimensões que estão mais desenvolvidas e as que ainda precisam de mais amadurecimento, além de permitir avaliar o trabalho de Orientação Profissional desenvolvido.

\subsubsection{Grupo Operativo}

Neste estudo a interpretação do processo grupal de Orientação Profissional foi realizada a partir de um sistema de avaliação básica, denominado de Vetores do Cone Invertido de Pichon-Rivière (QUIROGA, 1994). O Grupo Operativo avaliado por meio desse Sistema de Avaliação do Cone Invertido é constituído de seis vetores: (1) afiliação e pertença, (2) pertinência, (3) cooperação, (4) comunicação, (5) aprendizagem e (6) tele. O primeiro vetor é o de (1) afiliação e pertença, é o primeiro nível de identificação com a tarefa e os demais integrantes, neste momento os integrantes estão se conhecendo e começando a desenvolver um certo compromisso em relação ao grupo. Por sua vez, no segundo vetor (2) pertinência permite verificar o centramento do grupo na tarefa. Avalia-se este vetor pelo grau de compromisso dos integrantes com a tarefa. O terceiro vetor (3) cooperação consiste na colaboração entre os integrantes para a execução da tarefa, cada um contribui com o que pode, como pode e quando pode em complementaridade. O que indica o quarto vetor (4) a comunicação, é avaliado considerando o conteúdo e a metacomunicação dos integrantes, como se estabelece a interação entre os integrantes. O quinto vetor (5) aprendizagem desenvolve-se a partir das informações veiculadas no grupo, que produzem mudanças qualitativas no grupo, que se traduz em termos de resolver as ansiedades, de adaptação ativa à realidade, de criatividade etc. E a (6) tele, sexto vetor, consiste no clima grupal, na disposição positiva ou negativa do grupo com o coordenador, observador, dos integrantes entre si e com a tarefa (PICHON-RIVIÈRE, 1994, 1995; QUIROGA, 1994).

No presente trabalho, serão avaliados os vetores: comunicação e aprendizagem. A comunicação é o mecanismo fundamental em todo o grupo, ou seja, a interação, que vai se processar através das distintas vias de comunicação. Segundo Watzlawick; Beavin; Jackson (1967) do Instituto de Pesquisa Mental de Palo Alto, Califórnia, a comunicação está na base da vida humana nas relações sociais, sendo essencial para o processo de interação de troca 
entre as pessoas, não é uma mera transmissão de informação. “Assim, desde esta perspectiva pragmática, todo o comportamento, não só a fala, é comunicação; e toda a comunicação, mesmo as pistas comunicacionais num contexto impessoal, afeta o comportamento" (WATZLAWICK; BEAVIN; JACKSON, 1967, p. 19).

O conceito de comunicação para Pichon-Rivière é baseado nos teóricos do Instituto de Palo Alto. O esquema consiste em um emissor, um receptor e um canal que circula entre ambos. O emissor, para emitir uma mensagem, tem que codificá-la, esta mensagem vai circular por um canal de comunicação para poder emitir uma resposta que fecha este circuito. Para tanto, é fundamental que exista um código em comum, para que os participantes possam se entender. Na comunicação leva-se em conta não só o conteúdo da mensagem, mas o como e quem a emite (metacomunicação). No momento em que aparecem elementos de contradição entre os participantes, configura-se um mal-entendido no grupo e é quando há perturbação na comunicação. Estas perturbações são os ruídos, ou obstáculos epistemofílicos para Bachelard que, na teoria de Pichon-Rivère, adquirem a dimensão de "terceiro" existente no vínculo (GARCIA; WAISBROT, 1981). No grupo podem existir distintas modalidades de comunicação: de um para todos (pode gerar dependência), de todos para um (instala-se o bode expiatório), entre dois (isolam-se do grupo), ou entre todos. A comunicação ideal seria o tipo de comunicação de todos com todos, de uma maneira orgânica, na qual o que é falado é ouvido por todos os integrantes e, assim, a comunicação se torna fluida.

A aprendizagem, por sua vez, nesse modelo teórico, se dá por uma somatória de informações que cada um dos participantes (integrantes, coordenador) do grupo vão trazendo e trocando entre si e, que em determinado momento, promove um salto qualitativo dos integrantes. Desta forma, se produz a aprendizagem, que se traduz grupalmente em termos de criatividade, elaboração das ansiedades, resolução dialética das contradições e de adaptação ativa à realidade. Nesse processo de aprendizagem não se espera uma simples transmissão do 'saber' ou da informação, mas uma ação formadora do sujeito para a vida, uma ação transformadora de uma realidade. Assim, o Grupo Operativo está centrado no processo de inserção do sujeito no grupo e na tarefa, o que inclui o motivo da constituição do grupo nível explícito - e a elaboração das ansiedades a serviço da resistência à mudança - nível implícito. A tarefa consiste no conjunto de ações destinadas à conquista de objetivos comuns, é através dela que se viabiliza a mudança e o grupo pode pensar e elaborar as questões referentes à escolha da profissão.

No presente estudo, a finalidade consistirá na busca da informação profissional produtiva para as decisões de carreira e, para tal, várias tarefas deverão ser realizadas a cada 
encontro e em todo o processo grupal. Assim sendo, o modelo denominado de Esquema Conceitual Referencial Operativo (ECRO) será utilizado como parâmetro para o registro e a análise qualitativa dos dados.

O Grupo Operativo parece ser adequado para os propósitos desse estudo, principalmente por se tratar de adolescentes que têm o seu desenvolvimento facilitado em grupo. Para Delgado; Gutiérrez (1995, p.356), “[...] por suas características, o grupo operativo é uma excelente técnica de investigação social, aplicável praticamente a todo tipo de situações”.

\subsection{Procedimento de coleta de dados}

O QIP foi aplicado e testado em 2005 e 2006 em todos os usuários do SOP com fins de verificação da pertinência do uso do referido instrumento (ESBROGEO, M.C; MELOSILVA, L. L, 2007). O procedimento de intervenção em grupo operativo, objeto de análise neste estudo, foi realizado no período de abril a junho de 2006. Os dois procedimentos de intervenção foram realizados pela própria pesquisadora (pesquisa-ação), contando com a colaboração de duas psicólogas observadoras.

A seguir o SOP é apresentado, descreve-se como foi a composição dos grupos A e B e o planejamento dos encontros realizados para a obtenção dos dados.

\subsubsection{Serviço de Orientação Profissional}

Os dados foram obtidos por meio dos atendimentos realizados no Serviço de Orientação Profissional (SOP / CPA / FFCLRP-USP). O atendimento realizado no SOP fundamenta-se no referencial clínico-operativo (MELO-SILVA; JACQUEMIN, 2001, MELO-SILVA, 2003). O método clínico-operativo integra as contribuições de Achtnich (1991), Bohoslavsky (1991), de Müller (1988) e de Pichon-Riviére (1994,1995). A concepção da estratégia clínica é bastante adequada, pois se caracteriza por ser "uma estratégia de abordagem do objeto de estudo, que é o comportamento humano” (BOHOSLAVSKY, 1991, p. 33). É nessa perspectiva que o SOP tem desenvolvido suas estratégias de intervenção individual ou grupal. Os atendimentos são realizados por psicólogo-estagiários, alunos do curso de Psicologia (ou profissionais) matriculados nas disciplinas-estágio: Grupo de 
Orientação Profissional e / ou Intervenção Individual em Desenvolvimento de Carreira. O atendimento é realizado sob a supervisão da docente responsável pelo SOP, orientadora deste estudo, e por profissionais - psicólogos - do grupo de estudos e pesquisa, o Programa Vita.

O referido serviço atende pessoas acima de 14 anos. Seguindo a ordem de inscrição, o cliente é chamado para uma entrevista de triagem realizada individualmente por um estagiário, objetivando investigar os motivos da consulta, as expectativas sobre 0 atendimento, os dados pessoais, familiares, escolares, de trabalho e de saúde, incluindo antecedentes de atendimento psicológico. O serviço é apresentado ao candidato explicitandose o funcionamento, a duração e as modalidades de atendimento, os instrumentos e os tipos de técnicas utilizadas. Ao concluir a entrevista, o entrevistado responde a Escala de Maturidade para a Escolha Profissional (EMEP), e o estagiário faz as anotações necessárias, registra se é situação de orientabilidade, e faz sua indicação para orientação profissional individual ou em grupo, modalidade que dispõe de maior número de vagas. Quando necessário, procede-se ao encaminhamento de casos para psicodiagnóstico e/ ou psicoterapia na própria clínica-escola ou na comunidade. $\mathrm{O}$ atendimento em grupo é realizado em cerca de 12 sessões de duas horas cada. Entre os grupos do SOP dois foram constituídos para fins deste estudo.

\subsubsection{Composição dos grupos para a intervenção}

A pesquisadora juntamente com a equipe do SOP selecionou, entre as inscrições dos jovens que procuram o serviço no ano de 2006, os que realizaram a entrevista de triagem e responderam à EMEP. Os grupos foram formados considerando as variáveis deste estudo e os horários disponíveis para a maioria dos orientados em concordância com os da pesquisadora. Assim, a coleta de dados do presente estudo foi realizada no SOP com os clientes atendidos em grupo de adolescentes que aderiram voluntariamente ao estudo. A demanda total do serviço possibilitou a composição de sete grupos com os adolescentes, dois dos quais foram constituídos conforme critérios deste estudo, descritos anteriormente, e coordenados pela pesquisadora no primeiro semestre de 2006. Os grupos desta pesquisa foram montados com vinte integrantes cada, segundo os critérios: (1) 50\% de cada sexo e (2), maturidade, abaixo (Grupo A) e na média (Grupo B). Tais informações, a escola de procedência pública (PU) e a privada (PR), a escolaridade $\left(1^{\circ}, 2^{\circ}\right.$ e $3^{\circ}$ colegial e Ensino Médio Completo) e a idade são apresentadas nas Tabelas 1 e 2.

O Grupo A foi constituído por adolescentes que apresentaram maturidade total Muito Inferior (I) de percentil 1 e Inferior (I) de percentil 5-10. No Grupo B foram reunidos os 
adolescentes com maturidade total classificadas no grau Médio Inferiores (MI) de percentil 20-25, e Médio (M) de percentil 30-70. Os adolescentes, que obtiveram maturidade total Médio Superior (MS) de percentil 75-80, Superior (S) de percentil 90-95, Muito Superior (S+) de percentil 99, não foram incluídos na amostra, uma vez que sujeitos classificados nestes níveis apresentam mais recursos internos para efetivar a escolha da profissão e são em número menor no SOP, inviabilizando a constituição de um grupo nesses níveis de maturidade.

Para Neiva (1999, p. 15), “a EMEP é um instrumento diagnóstico e como tal permite detectar aqueles alunos que, por apresentarem um baixo nível de maturidade para a escolha profissional, necessitariam de participar de um processo de orientação profissional”. É nesse sentido que os grupos foram constituídos para fins deste estudo com a maturidade para escolha abaixo ou dentro da média. A Tabela 1 mostra a distribuição inicial dos grupos A e B, conforme critérios de inclusão/exclusão: sexo e maturidade, e as características sóciodemográficas: idade, procedência escolar e série no Ensino Médio.

Tabela 1 - Distribuição dos participantes dos Grupos A e B, em função das características sócio-demográficas e do nível de maturidade profissional.

\begin{tabular}{|c|c|c|c|c|}
\hline GRUPO & & A (fi) & B (fi) & TOTAL \\
\hline \multirow[t]{2}{*}{ Sexo } & Masculino & 10 & 10 & 20 \\
\hline & Feminino & 10 & 10 & 20 \\
\hline \multirow[t]{5}{*}{ Idade } & 15 anos & 1 & 6 & 7 \\
\hline & 16 anos & 6 & 5 & 11 \\
\hline & 17 anos & 8 & 7 & 15 \\
\hline & 18 & 3 & 2 & 5 \\
\hline & 19 & 2 & 0 & 2 \\
\hline \multirow{2}{*}{$\begin{array}{l}\text { PROCEDÊNCIA } \\
\text { ESCOLAR }\end{array}$} & PÚBLICA & 3 & 7 & 10 \\
\hline & PARTICULAR & 17 & 13 & 30 \\
\hline \multirow{4}{*}{$\begin{array}{l}\text { ESCOLARIDADE } \\
\text { (Ensino Médio) }\end{array}$} & $1^{\circ}$ SÉRIE & 0 & 2 & 2 \\
\hline & $2^{\circ}$ SÉRIE & 3 & 5 & 8 \\
\hline & $3^{\circ}$ SÉRIE & 10 & 9 & 19 \\
\hline & $\begin{array}{l}\text { Ensino } \\
\text { completo }\end{array}$ & 7 & 4 & 11 \\
\hline \multirow[t]{6}{*}{ MATURIDADE } & MUITO & 8 & 0 & 8 \\
\hline & INFERIOR & & & \\
\hline & INFERIOR & 12 & 0 & 12 \\
\hline & MÉDIO & 0 & 9 & 9 \\
\hline & INFERIOR & & & \\
\hline & MÉDIO & 0 & 11 & 11 \\
\hline
\end{tabular}


O Grupo A foi organizado com 20 integrantes, todos avaliados, segundo a EMEP, como tendo a maturidade total, Muito Inferior(I-) ou Inferior(I), 10 de cada sexo. Dentre eles, 17 eram provenientes de escolas particulares e 3 de escolas públicas; três cursavam a segunda série, 10 a terceira série e 7 com o ensino médio completo. Quanto à idade: um integrante de 15 anos, seis de 16 anos, oito de 17 anos, três de 18 anos e dois de 19 anos. Neste grupo ocorreram três desistências, sendo que duas no início do processo e uma após seis encontros, por motivo de doença. Concluíram o processo no grupo A de Orientação Profissional 17 adolescentes. A intervenção do grupo A constou de doze encontros (sendo 10 em grupo e duas entrevistas individuais), com encontros semanais e a duração de duas horas. Não estão computadas aqui a inscrição e a entrevista de triagem, anteriores à composição do grupo.

O Grupo B foi organizado, também, com 20 integrantes, todos avaliados com a maturidade total na Média Inferior(MI) ou Média (M), 10 de cada sexo, sendo 13 provenientes de escolas particulares e 7 de escolas públicas; dois cursavam a primeira série, 5 a segunda série, 9 a terceira série e 4 com o ensino médio completo. A idade dos integrantes era: seis de 15 anos, cinco de 16 anos, sete de 17 anos e dois de 18 anos. No primeiro encontro três integrantes não compareceram, cinco integrantes desistiram do grupo entre o primeiro e o segundo encontro e um integrante após quatro encontros alegou que tinha realizado a sua escolha e não viria mais. Ao todo foram nove desistências sendo que 11 integrantes permaneceram até o final do grupo. A intervenção do grupo B constou de onze encontros (sendo nove em grupo e duas entrevistas individuais), com encontros semanais e a duração de duas horas.

O total de participantes nos Grupos A e B que concluíram o processo de Orientação Profissional foi de 28 adolescentes. Estes grupos ocorreram concomitantemente no primeiro semestre de 2006 em diferentes dias da semana e com duas horas de duração cada encontro. Os integrantes que permaneceram no Grupo A e no Grupo B até o final do processo grupal de Orientação Profissional, configuraram-se da forma descrita a seguir: 42,9\% integrantes do sexo feminino e $57,1 \%$ do sexo masculino, $17,9 \%$ de escola pública e $82,1 \%$ de escola particular, quanto à série de estudo 3,6\% eram da primeira, 25\% da segunda, 42,9\% da terceira e 28,6\% com o Ensino Médio completo. E a idade dos participantes, 75\% com idade entre 16 e 18 anos (14,3\%- 4 integrantes com 15 anos e 10,7\%- 3 integrantes com 19 anos).

Todas as variáveis foram controladas na constituição dos grupos, contudo sendo a pesquisa de intervenção com possibilidade de desistência, o número de participantes concluintes não pôde ser controlado. Outras duas variáveis importantes em estudos sobre escolha da carreira não puderam ser controladas, a saber: procedência escolar - pública e privada - e escolaridade. 
O que diferiu nos dois grupos, do início ao fim, foi o nível de maturidade profissional. Para o grupo A foram selecionados jovens classificados no nível de maturidade "muito inferior” ou "inferior” e o Grupo B foi constituído por jovens avaliados no nível "médio inferior" ou "médio”. As informações sobre o nível de maturidade nas sub-escalas e no total, de cada participante, encontram-se detalhadas na Tabela 2, objetivando apresentar o perfil da amostra inicial, em termos de maturidade para a escolha da carreira nos dois grupos de intervenção. Ainda que o Grupo A tenha sido constituído com integrantes avaliados no nível de maturidade para a escolha da carreira (Muito Inferior e Inferior) e o grupo B (Médio Inferior e Médio), observa-se que na sub-escala independência, a avaliação em ambos os grupos mostra certa equivalência.

Tabela 2 - Distribuição dos integrantes do Grupo A e B em função da Maturidade em cada sub-escala e na Maturidade Total segundo a EMEP.

\begin{tabular}{|c|c|c|c|c|}
\hline EMEP & Sub-escalas & & GRUPO A(fi) & GRUPO B (fi) \\
\hline \multirow[t]{21}{*}{ Atitudes } & \multirow[t]{7}{*}{ Determinação } & Muito Inferior (I-) & 2 & 0 \\
\hline & & Inferior (I) & 14 & 3 \\
\hline & & Médio Inferior (MI) & 4 & 6 \\
\hline & & Médio (M) & 0 & 11 \\
\hline & & Médio Superior (MS) & 0 & 0 \\
\hline & & Superior (S) & 0 & 0 \\
\hline & & Muito Superior (S+) & 0 & 0 \\
\hline & \multirow[t]{7}{*}{ Responsabilidade } & Muito Inferior (I-) & 3 & 0 \\
\hline & & Inferior (I) & 8 & 1 \\
\hline & & Médio Inferior (MI) & 5 & 2 \\
\hline & & Médio (M) & 4 & 13 \\
\hline & & Médio Superior (MS) & 0 & 2 \\
\hline & & Superior (S) & 0 & 2 \\
\hline & & Muito Superior (S+) & 0 & 0 \\
\hline & \multirow[t]{7}{*}{ Independência } & Muito Inferior (I-) & 1 & 0 \\
\hline & & Inferior (I) & 4 & 4 \\
\hline & & Médio Inferior (MI) & 3 & 6 \\
\hline & & Médio (M) & 11 & 8 \\
\hline & & Médio Superior (MS) & 0 & 1 \\
\hline & & Superior (S) & 0 & 0 \\
\hline & & Muito Superior (S+) & 1 & 1 \\
\hline \multirow[t]{14}{*}{ Conhecimentos } & \multirow[t]{7}{*}{ Autoconhecimento } & Muito Inferior (I-) & 2 & 0 \\
\hline & & Inferior (I) & 8 & 3 \\
\hline & & Médio Inferior (MI) & 7 & 3 \\
\hline & & Médio (M) & 3 & 11 \\
\hline & & Médio Superior (MS) & 0 & 1 \\
\hline & & Superior (S) & 0 & 2 \\
\hline & & Muito Superior (S+) & 0 & 0 \\
\hline & Conhecimento $\mathrm{da}$ & Muito Inferior (I-) & 8 & 1 \\
\hline & Realidade & Inferior (I) & 5 & 3 \\
\hline & \multirow[t]{5}{*}{ Profissional } & Médio Inferior (MI) & 4 & 7 \\
\hline & & Médio (M) & 3 & 8 \\
\hline & & Médio Superior (MS) & 0 & 1 \\
\hline & & Superior (S) & 0 & 0 \\
\hline & & Muito Superior (S+) & 0 & 0 \\
\hline \multirow[t]{2}{*}{ Maturidade Total } & & & $\mathrm{I}-=8$ & $\mathrm{MI}=9$ \\
\hline & & & $\mathrm{I}=12$ & $M=11$ \\
\hline
\end{tabular}




\subsubsection{O processo grupal em Orientação Profissional}

Para Pichon-Rivière (1994) cada pessoa possui experiências, conhecimentos e afetos únicos com os quais ela pensa e age, porém é no trabalho em grupo que tais experiências podem adquirir unidade e crescimento, interagindo em uma comunicação criadora. O grupo se constitui um espaço para ensinar e aprender, uma aprendizagem em espiral dialética e de troca entre os integrantes. Nesse processo, o papel do coordenador é agir como um “co-pensor”, ou seja, o papel de criar, manter e fomentar a comunicação no grupo. Neste estudo, além da coordenação em grupo operativo ter sido realizada com base no referencial teóricometodológico de Pichon-Rivière, técnicas auxiliares foram utilizadas com o objetivo de facilitar a discussão e a introdução de assuntos importantes para que os integrantes pudessem gradativamente construir seus caminhos em direção à escolha profissional.

Alguns encontros do Grupo A e do Grupo B foram planejados de maneira similar, entretanto à medida em que cada grupo se desenvolveu, as demandas nortearam o planejamento das atividades a fim de responder ao emergente grupal, conforme referencial teórico-metodológico. O Grupo A e o Grupo B foram planejados para ocorrer em doze encontros incluindo duas entrevistas individuais.

A coordenação dos grupos foi realizada pela pesquisadora que contou com a colaboração de duas observadoras, uma em cada grupo. Os papéis da coordenadora e das observadoras foram desempenhados segundo o ECRO de Pichon-Rivière. As observadoras silentes registravam as falas, o comportamento não verbal dos integrantes e as intervenções da coordenadora. Os registros de observação embasaram a análise qualitativa do processo grupal e subsidiaram o planejamento das sessões subseqüentes. Os encontros foram realizados no Serviço de Orientação Profissional (SOP / CPA / FFCLRP-USP), em salas apropriadas ao atendimento.

No início do processo grupal foi aplicado o QIP, sendo os próximos encontros planejados a partir das necessidades dos adolescentes, apontadas nos registros dos instrumentos, das técnicas e das atividades planejadas com conteúdos específicos da Orientação Profissional ou de integração grupal. A EMEP e o QIP novamente foram aplicados no último encontro para se avaliar todo o processo de Orientação Profissional e o desenvolvimento da escolha profissional do adolescente. A seguir, o planejamento detalhado de cada grupo é explicitado. 


\section{Planejamento dos encontros do Grupo A}

No início do Grupo A foi aplicada a técnica de apresentação individual em que os adolescentes com uma folha de papel em branco e várias canetas e lápis coloridos desenharam livremente algo que cada um gosta de realizar ou que revela alguma característica de si. O objetivo dessa técnica é facilitar a apresentação e promover o conhecimento entre os integrantes, objetivando a mútua representação interna, ou seja, a formação dos vínculos entre os integrantes. A seguir em subgrupos foi aplicada a Técnica do Cartaz (MÜLLER, 1988, SOARES-LUCCHIARI, 1993). Essa técnica expressiva consiste na colagem de figuras e palavras de revistas/ jornais e desenhos livres, objetivando verificar as expectativas dos integrantes em relação ao grupo de Orientação Profissional. A atividade prosseguiu com um grupo de discussão no qual cada subgrupo apresentou o cartaz elaborado, explicitando as expectativas e as dúvidas. No encerramento foram esclarecidas questões referentes ao processo de atendimento e informado sobre o contrato de trabalho, estabelecendo o enquadre de funcionamento do grupo.

No segundo encontro o Questionário de Informação Profissional (QIP) foi aplicado e em seguida aplicado à Técnica do Cine Adolescente (SOARES-LUCCHIARI, 1993) Nessa técnica cada integrante escolhe o personagem de algum filme de que tenha gostado e em duplas conversam sobre os motivos da escolha por determinado personagem e em que se identificam com ele. O objetivo desta técnica é tornar os membros do grupo conhecidos e levantar interesses profissionais através da identificação com os personagens dos filmes. Ela promove também o autoconhecimento, que nesta fase inicial do grupo é útil para desenvolver a afiliação (pertença) no grupo. A atividade encerra-se e o Grupo Operativo começa para permitir a elaboração das questões levantadas. Ao final foi entregue uma lista de sites da internet para pesquisarem os cursos e profissões de interesse.

No terceiro encontro foi aplicada a Técnica de Role-playing do papel profissional com o objetivo de "trabalhar em nível corporal a vivência do papel profissional e permitir uma tomada de consciência do que o jovem sabe e do que não sabe sobre as profissões. Sensibilizar para as sensações de ver-se no papel” (MAHL; SOARES; OLIVEIRA NETO, 2005, p.126). O coordenador inicia a atividade, arremessando uma almofada a um integrante e diz aleatoriamente o nome de uma profissão. A seguir, esse integrante pega a almofada e se imagina no papel daquele profissional, apresenta-se ao grupo dizendo quem é, o que faz, onde, trabalha, há quanto tempo e depois os demais integrantes fazem perguntas sobre a profissão, mercado de trabalho etc. Ao terminarem os questionamentos, o integrante 
arremessa a almofada para outro integrante do grupo e diz o nome de uma profissão, a atividade se repete até o último integrante.

No quarto encontro, como aquecimento, foi desenvolvida a Técnica do Bombom, (LEVENFUS, 2002), que possibilita pensar em critérios de escolha sem experimentação. Em sub-grupos é realizada a leitura do livreto "Conversa na Cozinha: escolha da carreira” (MELO-SILVA; PEREIRA, 2002) com o objetivo de trabalhar as variáveis que influenciam na escolha da carreira. A Técnica do Bombom e a leitura do Livreto fornecem o conteúdo que é disparador temático para o Grupo Operativo. Ao final do encontro são propostas duas atividades como tarefa para casa. A primeira atividade objetiva o autoconhecimento, trata-se de um questionário com três perguntas: “(1) Quem sou eu? (2) Como os outros me vêem? E (3) Como eu gostaria de ser?”, de autoria desconhecida. E, a segunda atividade “A História do meu nome” é proposta, a fim de envolver a participação dos pais, consiste em verificar como foi a escolha do nome de cada um, com o intuito de levantar as expectativas prévias dos pais em relação aos filhos e promover um conhecimento da história de vida de cada um. Além de poder promover o diálogo entre pais e filhos sobre questões de escolha.

No quinto encontro há a apresentação de quatro integrantes sobre suas pesquisas na internet, as profissões escolhidas foram: Direito, História, Economia e Jornalismo. Os integrantes descreveram as atividades realizadas em casa e em subgrupos leram o Texto “Detetive de si mesmo” (DIAS, 2002). No Grupo Operativo os integrantes discutiram as dúvidas suscitadas no dia. A atividade proposta para casa foi a confecção da ARGEVOC (árvore genealógica profissional de MÜLLER, 1988) ou Genoprofissiograma (SOARESLUCCHIARI, 1997). A construção da árvore genealógica das profissões dos familiares tem o objetivo de promover o conhecimento das influências familiares e as expectativas em torno da escolha da profissão.

O jovem, inserido numa família com seu dinamismo próprio, escolhe uma profissão muitas vezes sem conhecer as influências recebidas do meio familiar. A genealogia - a rede de relações formadas em cada família que inclui os avós, bisavós, tios, primos - está presente de uma maneira ou de outra nas diferentes escolhas realizadas na vida, em especial na profissão a seguir (MAHL; SOARES; OLIVEIRA NETO, 2005, p.107).

No sexto encontro, sob a liderança da coordenadora, dois subgrupos foram organizados a fim de aplicar o Teste de Fotos de Profissões (BBT): método projetivo para a clarificação da inclinação profissional, de ACHTNICH (1991), nas versões brasileiras: masculina (JACQUEMIN, 2000) e feminina (JACQUEMIN et. al., 2006). O BBT-Br é 
publicado e comercializado no Brasil pelo Centro Editor de Testes e Pesquisas em Psicologia. A aplicação foi coletiva, porém cada participante utilizou um conjunto de fotos individualmente. Ao mesmo tempo, coordenado pela observadora, o outro subgrupo realizou a atividade Critérios para a escolha profissional (NEIVA, 2003a), publicado e comercializado pela Vetor Editora. Essa tarefa permite ao adolescente definir alguns critérios que podem auxiliá-lo na escolha profissional, sendo que os critérios contidos no jogo são: ambiente de trabalho, objetos/ conteúdos de trabalho, atividades de trabalho, rotina de trabalho e retornos do trabalho. Como atividade extra grupo sugeriu-se pesquisar as profissões selecionadas e registradas na atividade Realidade Profissional, segunda parte dos Critérios (NEIVA, 2003a), objetivando promover a discussão e a reflexão sobre os critérios de cada participante e as relações dos mesmos com as carreiras escolhidas. Tal como no encontro anterior, no sétimo encontro, os subgrupos tiveram as atividades invertidas, em um subgrupo foram aplicados o Teste BBT e os demais integrantes realizaram a atividade Critérios para a escolha profissional e para casa foi solicitada a mesma tarefa.

No oitavo encontro os integrantes discutiram inicialmente sobre a tarefa que realizaram em casa, ou seja, a pesquisa sobre a atividade Realidade Profissional (NEIVA, 2003a), e alguns integrantes trouxeram a apresentação de profissões, como: Relações Internacionais, Fisioterapia, Engenharia Elétrica e Administração. Em Grupo Operativo, fizeram reflexões sobre os resultados do BBT-Br, ou seja, sobre a estrutura de inclinação profissional de cada um dos integrantes.

Na continuação, o nono encontro foi dedicado às entrevistas individuais, que foram agendadas no mesmo dia e nos respectivos horários da realização dos grupos, por serem os de maior disponibilidade para todos os participantes. O objetivo dessas entrevistas foi de focalizar a escolha de cada integrante, levantar possibilidades e dificuldades, como de questões pessoais, familiares, financeiras etc, esclarecer dúvidas, enfim dedicar um espaço a cada participante para refletir sobre suas especificidades. A partir dessas entrevistas a equipe pode programar os últimos encontros baseados nas necessidades observadas.

Alguns integrantes apresentaram as profissões: Enfermagem, Medicina, Biologia, Turismo, no início do décimo encontro. Depois em subgrupos leram textos informativos sobre: o Exame Nacional do Ensino Médio (ENEM), o Sistema de Cotas Universitárias, Programa Universidade para todos (ProUni) e o Fundo de Financiamento ao Estudante do Ensino Superior (FIES). E em Grupo Operativo discutiram e refletiram sobre esses temas.

O encerramento em grupo foi realizado no décimo primeiro encontro, logo de início respondendo a EMEP e ao QIP. Em seguida, os integrantes apresentaram as profissões: 
Arquitetura, Geografia e Educação Física. Os integrantes foram subgrupados para a leitura dos textos: "Profissão, no rumo da vida” (DIAS, 2002) e "O Brasil desempregado" (MATTOSO, 1999). Em grupo, cada subgrupo apresentou o seu texto oralmente e discutiu os temas de maior interesse. Para encerrar o grupo foi realizada uma técnica de relaxamento na qual cada um se imaginava daqui a 10 anos em um dia de trabalho e a técnica do Aeroporto (SOARES-LUCCHIARI, 1997), em que cada um se imagina encontrando com um colega do grupo num aeroporto. O objetivo dessa técnica é: “Trabalhar a separação do grupo e os sentimentos que despertam. Propiciar a expressão de fantasias em relação ao afastamento do grupo e a resolução de seu problema de escolha” (SOARES-LUCCHIARI, 1997, p.67). Em seguida cada um livremente conta ao grupo o que pensou. O grupo é encerrado e as entrevistas de encerramento do processo são agendadas individualmente para a semana subseqüente.

\section{Planejamento dos encontros do Grupo B}

O Grupo B, como o Grupo A teve como técnica de apresentação individual a realização de um desenho livre sobre as atividades que cada integrante gosta de realizar e depois a Técnica do Cartaz (MÜLLER, 1988, SOARES-LUCCHIARI, 1993) realizada em sub-grupos, com a colagem de fotos de revistas, jornais e a utilização de desenhos livres. A atividade foi encerrada com o grupo de discussão, no qual cada sub-grupo apresentou o cartaz e os participantes trocaram suas impressões. Ao final do encontro foram tratados os assuntos relativos ao processo de atendimento e ao contrato de trabalho, sendo as dúvidas esclarecidas.

No segundo encontro foram aplicados: o Questionário de Informação Profissional (QIP) e a técnica do Cine Adolescente (SOARES-LUCCHIARI, 1993). O Grupo Operativo encerrou as atividades com a discussão dos assuntos do dia. Ao final do encontro uma lista de sites da internet foi disponibilizada com o objetivo de pesquisarem os cursos e profissões de interesse.

Com a Técnica do barbante deu-se o início ao terceiro encontro. Utilizando um barbante o primeiro integrante fala algo de si (algo de que gosta, que faz bem) segura um pedaço da linha e joga o barbante ao outro e assim sucessivamente até o último integrante, formando uma trama de linhas, o último integrante retorna o barbante para o integrante que jogou para ele até a trama se desfazer gradativamente. Nesse momento cada um tenta repetir o que cada integrante falou de si e joga o barbante, fazendo o caminho inverso. O objetivo desta técnica é propiciar um maior conhecimento entre si, de fortalecer o vínculo do grupo e 
facilitar a comunicação entre eles. Em sub-grupo os participantes lêem o Texto "Detetive de si mesmo” (DIAS, 2002) e no Grupo Operativo discutem e elaboraram as dúvidas suscitadas no dia. Como atividades para casa, foi solicitada a ARGEVOC (MÜLLER, 1988) ou Genoprofissiograma (SOARES-LUCCHIARI, 1997), ou seja, a construção da árvore genealógica da família informando o nome, idade, profissão e interesses de cada familiar. E a segunda atividade para com os pais investigarem “A História do meu nome”.

O quarto encontro começa com as apresentações de dois integrantes que realizaram uma pesquisa na internet sobre a profissão de Artes Cênicas. Os integrantes relatam sobre as tarefas propostas para casa (“A Historia do meu nome” e o ARGEVOC /Genoprofissiograma). Estes temas são os disparadores temáticos do Grupo Operativo que finaliza com a confecção individual de cada integrante de uma "Carta aos pais” (SILVA; VENTURINI; MELO-SILVA, 2005). A atividade proposta para casa é que respondam às três questões: (1) Quem sou eu? (2) Como os outros me vêem? (3) Como eu gostaria de ser? Com o objetivo de aprofundar o conhecimento sobre si mesmo.

O quinto encontro no Grupo B começou com a apresentação de quatro integrantes que pesquisaram sobre as profissões: Biologia, Química, Ciências Sociais e Economia. Para então realizarem a Técnica das frases para completar (BOHOSLAVSKY, 1991), adaptada por (SOARES-LUCCHIARI, 1997), com o objetivo de auxiliar o orientando sobre a possibilidade de escolha, além de levantar importantes questões a serem refletidas. Foi proposto que em casa refletissem sobre a atividade e completassem as frases com mais informações.

O Grupo B no sexto encontro procedeu às apresentações de duas profissões: Veterinária e Agronomia. Após a realização da atividade Critérios para a escolha profissional (NEIVA, 2003a), o grupo refletiu sobre a realização da tarefa. Para casa foi sugerida a atividade Realidade Profissional (NEIVA, 2003a).

O Teste BBT foi realizado no sétimo encontro em todo o grupo, a aplicação foi coletiva, porém cada participante utilizou um conjunto de fotos individualmente. No encontro seguinte, o oitavo, houve inicialmente a discussão das tarefas realizadas em casa de pesquisa sobre as profissões escolhidas na atividade Realidade Profissional (NEIVA, 2003) e alguns integrantes trouxeram a apresentação das profissões: Direito, Pedagogia e Administração. Em grupo operativo trabalharam com a estrutura de inclinação do BBT através dos oito fatores e das diversas profissões de interesse.

O nono encontro foi dedicado às entrevistas individuais, agendadas no mesmo dia e nos respectivos horários da realização dos grupos, por serem os de maior disponibilidade para 
todos os participantes. Essas entrevistas nortearam algumas modificações que ocorreram nos próximos encontros.

O encerramento do Grupo B foi realizado no décimo encontro, sendo que inicialmente responderam à EMEP e depois ao QIP. À medida que terminavam, liam o texto: "Profissão, no rumo da vida” (DIAS, 2002) e “O Brasil desempregado” (MATTOSO, 1999). Em grupo discutiram os temas abordados nos referidos textos. Para encerrar o grupo foi realizada uma técnica de relaxamento na qual cada um se imaginava daqui a 10 anos em um dia de trabalho e a técnica do Aeroporto (SOARES-LUCCHIARI, 1993), em que cada um se imagina encontrando com um colega do grupo num aeroporto. Em seguida cada um livremente conta ao grupo o que pensou. O grupo é finalizado e as entrevistas de encerramento são agendadas individualmente para a semana subseqüente. A Tabela 3 mostra a síntese das atividades desenvolvidas em cada grupo.

Tabela 3 - Síntese dos temas desenvolvidos no Grupo A e no Grupo B.

\begin{tabular}{|c|c|c|}
\hline \multirow[t]{2}{*}{ SESSÃO } & \multicolumn{2}{|l|}{ TEMAS } \\
\hline & GRUPO A & GRUPO B \\
\hline $1^{\mathrm{a}}$ & Apresentação e expectativas & Apresentação e expectativas \\
\hline $2^{\mathrm{a}}$ & $\begin{array}{l}\text { QIP/ Conhecer } \quad \text { o } \quad \text { grupo/ } \\
\text { autoconhecimento } \\
\text { Tarefa- lista de sites }\end{array}$ & $\begin{array}{l}\text { QIP/ Conhecer } \quad \text { o } \quad \text { grupo/ } \\
\text { autoconhecimento } \\
\text { Tarefa- lista de sites }\end{array}$ \\
\hline $3^{\mathrm{a}}$ & $\begin{array}{l}\text { Sensibilização para a busca de } \\
\text { informações profissionais }\end{array}$ & $\begin{array}{l}\text { Conhecer o grupo/ autoconhecimento } \\
\text { Tarefa- influências familiares }\end{array}$ \\
\hline $4^{\mathrm{a}}$ & $\begin{array}{l}\text { Influências na escolha profissional } \\
\text { Tarefa- autoconhecimento }\end{array}$ & $\begin{array}{l}\text { Influências na escolha profissional } \\
\text { Tarefa- autoconhecimento }\end{array}$ \\
\hline $5^{\mathrm{a}}$ & $\begin{array}{l}\text { Autoconhecimento } \\
\text { Tarefa- influências familiares }\end{array}$ & Autoconhecimento \\
\hline $6^{\mathrm{a}}$ & Teste BBT-Br / atividade Critérios & Atividade Critérios \\
\hline & $\begin{array}{l}\text { Tarefa- pesquisa informação } \\
\text { profissional }\end{array}$ & $\begin{array}{l}\text { Tarefa- } \quad \text { pesquisa } \\
\text { profissional }\end{array}$ \\
\hline $7^{\mathrm{a}}$ & $\begin{array}{l}\text { Teste BBT-Br / atividade Critérios } \\
\text { Tarefa- pesquisa informação } \\
\text { profissional }\end{array}$ & Teste BBT-Br \\
\hline $8^{\mathrm{a}}$ & $\begin{array}{l}\text { Informações profissionais } \\
\text { Tarefa- pesquisa informação } \\
\text { profissional }\end{array}$ & Informações profissionais \\
\hline $9^{a}$ & Entrevistas individuais & Entrevistas individuais \\
\hline $10^{\mathrm{a}}$ & Informações profissionais & Encerramento- EMEP/ QIP \\
\hline $11^{\mathrm{a}}$ & Encerramento- EMEP/ QIP & Entrevistas individuais \\
\hline $12^{\mathrm{a}}$ & Entrevistas individuais & \\
\hline
\end{tabular}




\subsection{Tratamento de dados}

Os dados selecionados para análise foram, principalmente, os obtidos por meio do QIP, da EMEP e do registro das sessões de grupo operativo. Considerando a importância da análise quantitativa, assim como da análise qualitativa das informações, este estudo foi delineado na perspectiva de integrar as duas estratégias de obtenção e de análise dos dados: a quantitativa e a qualitativa.

“A realidade concreta da investigação social nos informa uma e outra vez da insuficiência abstrata de ambos os enfoques tomados por separado" (DELGADO; GUTIÉRREZ, 1995, p.88). A utilização dos métodos qualitativos e quantitativos de modo combinado passou a ser chamado de triangulação de métodos e ser considerado como uma nova maneira de compreender o mundo dentro das complexidades e desafios da modernidade (MINAYO, 2005).

Para Minayo, as fundamentações da triangulação podem ser encontradas nas idéias de Kant, “a experiência se constrói na unidade sintética dos fenômenos, em uma síntese de conceitos sem o qual a ação não chegaria a se transformar em conhecimento” (MINAYO, 2005, p.30). Segundo a autora, a postura dialética leva a compreender que dados subjetivos e dados objetivos são inseparáveis e interdependentes, razão de as dicotomias serem diluídas.

Uma das maiores preocupações em se utilizar as duas abordagens, qualitativa e quantitativa, diz respeito a serem de paradigmas distintos e ao mesmo tempo complementares. As possibilidades são muitas, assim como os cuidados a serem considerados, entretanto não há dúvida de que os resultados podem ser surpreendentes.

CASBEER; VERHOEF (1997) citam as vantagens e os desafios em se combinarem os dois tipos de pesquisa. As vantagens são de uma abordagem poder ser usada para dar informações à outra, com o aumento da validade sendo os resultados confirmados mediante diferentes fontes de informação, a complementaridade e a criação de novas linhas de pensamento e de pesquisa em função do surgimento de novas perspectivas ou contradições. Os desafios nesta combinação são de ir além dos métodos e dos estudos em separado, fazer a colocação correta da pergunta: “o quanto”, “como” e “por que”, desenvolver estratégias para comparar e avaliar diferentes resultados e para harmonizar as contradições e ampliar o aprendizado por meio de um programa que combine métodos diferentes de pesquisa. Para estes autores os principais desafios ao se combinarem os dois métodos são: diferenças filosóficas, custo elevado, treinamento inadequado do pesquisador e viés de publicação. $\mathrm{Na}$ 
escolha de um método, o pesquisador deve estar em sintonia técnica bem como filosófica com o estudo e estes alinhados com os objetivos da pesquisa. Assim sendo, a opção pelo uso de estratégias quantitativas e qualitativas, neste estudo, visa superar alguns problemas metodológicos muitas vezes possíveis de ocorrer quando o pesquisador opta por apenas uma modalidade de análise.

Os dados obtidos por meio do Questionário de Informação Profissional (QIP), foram analisados quantitativamente (perguntas fechadas) com base na estatística descritiva e qualitativamente (comentários e perguntas abertas), com base na análise de conteúdo segundo Bardin (1988). A análise de conteúdo, neste estudo, foi organizada em torno de três pólos cronológicos: a pré-análise; a exploração do material; o tratamento dos resultados, a inferência e a interpretação. Na pré-análise, a primeira atividade consiste em realizar uma leitura flutuante para se estabelecer um contato com os documentos, depois da escolha dos documentos que segue algumas regras como: exaustividade, representatividade, homogeneidade e pertinência. E ainda, a formulação das hipóteses e dos objetivos, mesmo que provisórios, que se pretende verificar e a referenciação dos índices e a elaboração de indicadores, para então alcançar a exploração do material, que é a fase de análise propriamente dita e o tratamento dos resultados obtidos e interpretação.

Para melhor analisar a questão 5 do QIP ("Considerando suas preferências gostaríamos de saber qual (is) profissão (ões) desperta (m) mais o seu interesse”) as profissões informadas foram distribuídas em três grandes áreas: Humanidades, Biológicas e Exatas. Para tal, utilizou-se o Guia das Profissões da Universidade de São Paulo (A Universidade e as profissões, 2006), o Guia dos Estudantes (2006) comercializado pela Editora Abril e o Guia de Profissões da Universidade Estadual Paulista (UNESP, 2005). As profissões consideradas na área Humanidades foram: Administração, Arquitetura, Artes Cênicas, Artes Plástica, Audiovisual (cinema/ vídeo), Arquivologia, Biblioteconomia, Ciências Contábeis, Ciências Sociais, Dança, Design gráfico, Direito, Economia, Economia Agroindustrial, Editoração, Filosofia, Geografia, Gestão Ambiental, História, Jornalismo, Letras, Lingüística, Moda, Museologia, Musicoterapia, Música, Pedagogia, Publicidade e Propaganda, Produção Editorial, Relações Internacionais, Relações públicas, Secretariado Executivo, Serviço Social e Turismo. As profissões da área Biológicas incluídas foram: Ciências Biológicas, Ciências dos alimentos, Ecologia, Educação Física, Enfermagem, Engenharia Agronômica, Engenharia dos alimentos, Engenharia Florestal, Esporte, Farmácia - Bioquímica, Fisioterapia, Fonoaudiologia, Medicina, Medicina Veterinária, Nutrição, Oceanografia, Odontologia, Psicologia, Terapia Ocupacional, Zootecnia. E as carreiras da área Exatas englobam: Ciências 
da computação e informática, Ciências exatas, Engenharia, E. aeronáutica, Física, Física médica, Geofísica, Geologia, Matemática, Meteorologia, Oceanografia, Química, Astronomia, Desenho industrial, Estatística.

A intenção de controlar a variável maturidade para fins da intervenção e da avaliação, como apontado anteriormente, foi mantida até a composição dos grupos e início do tratamento dos dados. Porém, para efeito de análise final dos dados essa distinção não foi feita, por duas razões: (1) o número de participantes ao final da intervenção $(n=28)$ ficou abaixo do esperado e (2) a dimensão psicológica maturidade para a escolha de carreira, por estar em níveis muito próximos (inferior e médio) nesses sujeitos, não foi considerada como critério adequado para a análise em dois grupos. Assim sendo, os dados dos grupos A e B foram reunidos e analisados na totalidade $(\mathrm{n}=28)$.

Foram realizadas comparações entre o início e o término da intervenção em grupo de Orientação Profissional. Como se trata da mesma unidade amostral (pré X pós) utilizou-se o Teste não-paramétrico de Wilcoxon para comparações com números e o Teste do $\mathrm{X}^{2}$ de McNemar, nas comparações em porcentagens. Uma outra comparação realizada foi entre o sexo feminino e o masculino. Como as amostras são independentes, foram utilizados: o Teste Exato de Fisher nas comparações em porcentagem e o Teste não-paramétrico de MannWhitney nas comparações com números.

Os dados obtidos por meio da Escala de Maturidade para Escolha Profissional (EMEP) de Neiva (1999) foram analisados quantitativamente, sendo os resultados brutos por tratamento estatístico não paramétrico (Teste de Wilcoxon para amostras pareadas, $\mathrm{p}=<$ 0,05), para comparação dos índices obtidos antes e depois da intervenção em Orientação Profissional de ambos os grupos (A e B, n=28). E o Teste de Mann-Whitney na comparação realizada entre o sexo feminino e o masculino.

A análise qualitativa sobre o processo de Orientação Profissional dos grupos foi feita a partir da síntese dos registros dos grupos operativos, realizadas após cada encontro pela observadora e pela coordenadora. Os registros das falas tanto dos integrantes quanto da coordenadora foram analisados objetivando proceder à síntese do processo grupal. A análise do processo grupal focalizou o centramento do grupo na tarefa - de informação profissional e questões pertinentes à tomada de decisão - com base nas falas dos integrantes e da coordenação. A análise das transcrições das sessões focalizou predominantemente os vetores de avaliação do Cone Invertido: comunicação e aprendizagem, conforme ECRO (PICHONRIVIÈRE, 1994, 1995; QUIROGA, 1994). Os dados obtidos por meio dos instrumentos de avaliação psicológica foram integrados para avaliar o nível de informação profissional e o 
nível de maturidade profissional antes e depois da intervenção; e a comunicação e a aprendizagem no processo grupal de Orientação Profissional, como indicadores de possíveis mudanças expressas nos grupos.

A partir dos registros do acontecer grupal, foram construídas hipóteses acerca das relações causais, com o objetivo de decodificar o sentido do observado, explícito, denominado emergente por Pichon (1994,1995). Os conteúdos observados remetem ao significante e a significados implícitos, ao acontecer subjacente do processo interacional. O entendimento desses significados pode proporcionar aos adolescentes elementos que promovam a comunicação e aprendizagem de atitudes e aquisição de conhecimentos - informações - para a escolha da carreira.

\subsection{Considerações éticas}

No ato da inscrição para atendimento no SOP os candidatos a clientes recebem um impresso para ser assinado pelo usuário e um de seus responsáveis - quando com idade inferior a 18 anos. Este documento (Anexo A - Autorização para Orientação Profissional) dá ciência do atendimento a ser realizado e os signatários nele autorizam a eventual utilização dos dados para a realização de pesquisas, cujos resultados poderão ser divulgados e utilizados em aulas, preservando-se o sigilo sobre a identidade do orientado. Além deste documento, que é norma no serviço, foram utilizados mais dois: uma Carta de Apresentação (Apêndice B) que informa sobre o processo de Orientação Profissional e o Termo de Consentimento Livre e Esclarecido (Apêndice C) que após ciência e concordância foram assinados em duas vias uma para cada participante e outra para a pesquisadora.

O projeto de pesquisa foi submetido ao Comitê de Ética em Pesquisa da Faculdade de Filosofia, Ciências e Letras de Ribeirão Preto da Universidade de São Paulo, conforme Resolução 196/96 do Conselho Nacional de Saúde (conselho. saude.gov/Br/docs/Resoluções/Reso196.doc) e Resolução 16/00 do Conselho Federal de Psicologia (www.pol.org.br/legislacao/doc/resolucao2000_016.doc), sendo APROVADO, de acordo com o Processo CEP-FFCLRP número 232/2005 - 2005.1.1862.59.2 (Apêndice D). A partir do trabalho original aprovado pelo Comitê de Ética em Pesquisa foi alterado o título, sendo o mesmo notificado (Apêndice E).

Para a realização de pesquisas no âmbito dos Programas de Pós-graduação em Psicologia e junto às agências de fomento, as questões éticas formais foram contempladas. 
Porém destaca-se neste estudo a relevância de se cuidar das recomendações éticas, em geral, do Conselho Federal de Psicologia e da Associação Internacional de Orientação Escolar e Profissional (International Association for Educational and Vocational Guidance IAEVG/AIOSP, sigla em francês). Tanto na intervenção como na análise dos dados, tais recomendações foram norteadoras. Em geral, as normas da AIOSP (MELO-SILVA, 2003) estabelecem: (1) responsabilidades éticas para com os clientes, enquanto sujeitos atores de seus projetos de vida; (2) atitudes em relação a colegas e profissionais de áreas afins; (3) atitudes em relação aos governos e outras agências comunitárias; (4) responsabilidade em relação às pesquisas e aos processos relacionados; e (5) responsabilidade como orientador individual. No domínio da prática da Orientação Profissional, atentar para a condição do sujeito de ser agente ativo nas decisões sobre seu destino é uma questão ética muito importante, pois nenhum profissional por mais capacitado que seja deve decidir pelo cliente. 


\section{RESULTADOS E DISCUSSÃO}

Os resultados são apresentados e discutidos em três conjuntos de dados: (1) a informação profissional, (2) a maturidade para a escolha profissional e (3) o processo grupal. Para responder ao primeiro objetivo específico - avaliar ao nível de Informação Profissional - os dados foram obtidos por meio do Questionário de Informação Profissional (QIP) e tratados quantitativamente. A análise foi feita em duas comparações: a primeira do tipo pré e pós-intervenção em grupo de Orientação Profissional e a segunda comparação foi entre os sexos, considerando a totalidade da amostra $(n=28)$, como apontado anteriormente. A comparação entre os sexos está inserida na apresentação e discussão dos resultados apenas nas situações em que houve diferença significativa.

Para alcançar o segundo objetivo específico - avaliar ao nível de Maturidade para a escolha profissional - os resultados foram obtidos por meio da Escala de Maturidade para a Escolha Profissional (EMEP). Os dados são analisados, também, nas comparações pré e pósintervenção e entre os sexos.

O terceiro objetivo específico consiste em avaliar a intervenção em um grupo de orientação profissional, em função da comunicação e da aprendizagem. Para alcançar tais objetivos, os dados da intervenção são analisados a partir dos registros de cada encontro, bem como das atividades desenvolvidas, com base no referencial de grupo operativo de PichonRivière. Na análise qualitativa do processo de intervenção, as informações de cada grupo são analisadas separadamente, ou seja, Grupo A $(\mathrm{n}=17)$ e Grupo B $(\mathrm{n}=11)$. A análise qualitativa das sessões grupais possibilitou articulações com as informações obtidas nos dados sobre a Informação Profissional e a Maturidade, em complementaridade, resultando em análises acerca dos movimentos dialéticos em cada grupo.

\subsection{Informação Profissional}

Neste primeiro conjunto de dados sobre a Informação Profissional, são analisadas as respostas de toda a amostra, conforme resultados obtidos por meio do Questionário de Informação Profissional (QIP), na situação pré-intervenção em comparação com as respostas obtidas na finalização do processo (pós-intervenção). 
As respostas fornecidas à primeira questão: "Você acredita que os adolescentes estão suficientemente informados sobre profissões?” são apresentadas na Tabela $4^{7}$. Nas Tabelas 4 e 5 os dados são apresentados e analisados em tabela de contingência que comparam as freqüências no início (lado esquerdo, em linha) e no final da intervenção (lado direito, em coluna).

Tabela 4 - Distribuição (em porcentagem) dos adolescentes (n=28) em função da freqüência de respostas sobre a crença de que os adolescentes estão informados sobre as profissões, em dois momentos do processo (pré e pós).

\begin{tabular}{|c|c|c|c|c|c|c|}
\hline \multirow{2}{*}{ Questão 1} & \multicolumn{4}{|c|}{ Pós- intervenção } & \multirow{2}{*}{ Tota } & \\
\hline & Não & & Sim & & & \\
\hline Pré- intervenção & $\mathrm{Fi}$ & $\%$ & $\mathrm{Fi}$ & $\%$ & $\mathrm{Fi}$ & $\%$ \\
\hline Não & 20 & 71,4 & 3 & 10,7 & 23 & 82,1 \\
\hline Sim & 1 & 3,6 & 4 & 14,3 & 5 & 17,9 \\
\hline Total & 21 & 75,0 & 7 & 25,0 & 28 & 100,0 \\
\hline
\end{tabular}

A maioria dos jovens avalia que não estão bem informados (82,1\% pré-grupo e $75 \%$ pós-grupo). Cerca de $71,4 \%$ dos estudantes consideram, no princípio e no fim, que os adolescentes não estão suficientemente informados. Contudo, com o processo de Orientação Profissional cerca de 10,7\% (3 participantes) mudaram de opinião, no sentido de reconhecerem que os adolescentes têm informação, um integrante (3,6\%) mudou de opinião em sentido inverso: se no início da intervenção considerava que tinha informação ao final a sua opinião passa a ser negativa sobre o assunto.

Ainda que a ampla maioria de estudantes do Ensino Médio, que aspira à carreira universitária, faça uso das tecnologias de informação e comunicação, esse resultado mostra que tais recursos, além de outros, não são utilizados de maneira proveitosa para facilitar o conhecimento sobre as profissões. Conforme registros de alguns participantes no início do grupo de Orientação Profissional: "muitos adolescentes nem procuram pesquisar sobre profissões”; “as informações que os adolescentes obtêm sobre profissões são mínimas se comparadas à abrangência das mesmas” (integrantes do Grupo A); “os adolescentes atualmente não se informam sobre profissões de maneira assídua. É uma minoria que vai atrás” (Grupo B). Por outro lado, eles apontam a insuficiência de recursos informativos: “não existem muitos lugares onde se possa olhar e se informar sobre as profissões” (Grupo A);

\footnotetext{
${ }^{7}$ As Tabelas 4 e 5 os dados são apresentados e analisados em tabela de contingência que comparam as freqüências no início (lado esquerdo, em linha) e no final da intervenção (lado direito, em coluna).
} 
"falta informação por parte da escola e das próprias universidades"; "pois não tendo informações sobre todas as profissões eu posso acabar tomando decisões precipitadas”; “faltam informações mais objetivas sobre carreiras” (integrantes do Grupo B).

E, ao final do grupo de Orientação Profissional, alguns participantes do Grupo A continuam apontando as insuficiências tanto na oferta da informação profissional quanto de serviços e programa de orientação para a carreira: “acredito que falta buscar informações e até mesmo ajuda para decidir a profissão"; "os meios de comunicação tocam pouco no assunto, somente revistas específicas têm um bom conteúdo"; "a maioria não corre muito atrás, e a grande parte dos colégios não ajudam”; “acho que todas as escolas deveriam ter um cursinho de orientação profissional para os alunos saberem mais sobre as profissões”. E do Grupo B: “acredito que há poucas informações sobre as profissões, difícil acesso, pois não são todas as pessoas que têm acesso à internet, por exemplo"; "para mim os adolescentes não sabem quase nada sobre as profissões, mas eles também não correm atrás para conhecer cursos novos, novas áreas, mercados e assim por diante"; "é só questão de interesse"; "não acho que falta informação mais diretiva”.

Na segunda questão, "Você acredita que a informação profissional pode ajudá-lo (a) na tomada de decisão vocacional?”, 100 \% dos integrantes de ambos os grupos acreditam que sim, o que sinaliza boas expectativas em relação a programas online ou presenciais que objetivam a informação profissional. Todos os alunos consideram que as informações profissionais podem ajudá-los na tomada de decisão. Como dizem os participantes: “ $a$ informação profissional me leva a conhecer melhor cada profissão, o que facilita na tomada da decisão final (escolha da profissão)"; "acho que sim porque com mais informação fica mais fácil de decidir a profissão” (integrantes do Grupo A); “através das informações de profissões, podemos ver em qual nos encaixamos melhor, ou seja, aquela de que mais gostamos"; "pois poderei ver mais a fundo o que cada profissão tem a me oferecer" (integrantes do grupo B).

Ao final da intervenção em Orientação Profissional continuam a acreditar no auxílio da informação profissional para a escolha da profissão, sinalizando a importância de promover acesso facilitado para a busca de informações de formas e maneiras variadas para o adolescente. Um processo em que o adolescente possa ter acesso a informações de qualidade e que se sinta motivado para refletir sobre as mesmas. A seguir alguns comentários do Grupo A: “A informação profissional é extremamente importante, com ela é possível saber como são as profissões”; “Pois o estudante pode fazer sua escolha com mais segurança devido às informações que pode receber"; "Claro, quanto mais informação melhor apesar de às vezes confundir a cabeça né, 
quanto mais souber melhor, mais esclarecido". E os comentários Grupo B: "Podemos trocar dúvidas, idéias, confirmar ou não se estamos fazendo a escolha certa. Isso ajuda muito, mais poderia nos passar mais algumas informações sobre profissões, conversar com profissionais”; "Pois conhecendo cada profissão ao certo, posso ver qual se encaixa melhor em mim. Em qual me adapto melhor”; “Ajudando a descobrir o que realmente quero”.

Os registros das opiniões dos jovens estão em consonância com a literatura que aponta a importância da informação profissional, seja o recurso impresso e/ou o uso da internet. Porém, os estudos citados por Niles e Harris-Bowlsbey (2005) demonstram que a combinação do uso do computador e da intervenção do orientador profissional é o mais efetivo meio para o planejamento de carreira. Entretanto, caso não seja possível, apenas a utilização do computador permite mais benefícios do que não utilizar alguma assistência, o que reafirma o que os adolescentes nessa pesquisa comentam sobre os benefícios da informação profissional, considerando os comentários anteriores e o resultado da próxima questão.

A questão 3 indaga sobre“os recursos ou instrumentos utilizados para obter informações relativas às profissões e carreiras”. Trata-se de uma pergunta tipo likert que aborda o uso de recursos como: internet, guias, livros, revistas, programas de televisão, programas de rádio, filmes e outros. Em princípio, os dados sobre a utilização da internet são apresentados, separadamente, na Tabela 5.

Tabela 5 - Distribuição (em porcentagem) dos adolescentes (n=28) em função da freqüência de uso do recurso da internet para obter informações profissionais, em dois momentos do processo (pré e pós).

\begin{tabular}{lllllllllll}
\hline Questão 3 & \multicolumn{1}{l}{ Pós-intervenção } \\
\cline { 2 - 12 } & \multicolumn{2}{l}{ Raramente } & \multicolumn{1}{l}{ Ás vezes } & \multicolumn{1}{l}{ Freqüentemente } & \multicolumn{2}{l}{ Sempre } & \multicolumn{2}{l}{ Total } \\
Pré-intervenção & Fi & $\%$ & fi & $\%$ & Fi & $\%$ & fi & $\%$ & fi & $\%$ \\
Nunca & 0 & 0 & 3 & 10,7 & 0 & 0 & 1 & 3,6 & 4 & 14,3 \\
Raramente & 3 & 10,7 & 0 & 0 & 2 & 7,1 & 0 & 0 & 5 & 17,9 \\
Ás vezes & 0 & 0 & 4 & 14,3 & 3 & 10,7 & 2 & 7,1 & 9 & 32,1 \\
Freqüentemente & 0 & 0 & 1 & 3,6 & 2 & 7,1 & 2 & 7,1 & 5 & 17,0 \\
Sempre & 0 & 0 & 1 & 3,6 & 2 & 7,1 & 2 & 7,1 & 5 & 17,9 \\
Total & 3 & 10,7 & 9 & 32,1 & 9 & 32,1 & 7 & 25,0 & 28 & 100,0 \\
\hline
\end{tabular}

No princípio da intervenção, os resultados mostram que 10 (34.9\%) jovens (17,0\% freqüentemente e 17,9\% sempre) utilizam a internet, nove participantes (32,1\%) às vezes utilizam a internet, sendo que raramente e nunca são nove (32,2\%). Em relação à utilização da internet, os resultados do final da intervenção mostram que existem $16(57,1 \%)$ jovens $(32,1 \%$ 
freqüentemente e 25\% sempre) utilizam bastante a internet para obter informação, nove deles $(32,1 \%)$ continuam a utilizar às vezes e, três $(10,7 \%)$ raramente. Nenhum jovem assinalou mais a respostas nunca. Isto é, após intervenção todos continuam ou ampliam a busca da informação via internet.

Na utilização da internet, a comparação entre o pré-grupo (mediana 3,00, média 3,07 e desvio padrão 1,30) e o pós-grupo (mediana 4,00, média 3,71 e desvio padrão 0,98) evidencia diferença significativa $(\mathrm{p}=0,01)$, o que é um resultado bastante favorável à avaliação da intervenção, uma vez que há aumento no uso das tecnologias para a busca de informação profissional, estimulada no processo de intervenção e verificada ao término.

Ainda na questão 3 em relação ao uso dos recursos, de um modo geral, a Tabela 6 mostra a freqüência e a porcentagem em cada um deles, antes e após intervenção nos grupos de orientação profissional. A escala likert de 5 pontos foi agrupada em três categorias avaliativas: nunca/ raramente, às vezes e freqüentemente/ sempre, afim de facilitar a interpretação dos dados.

Tabela 6 - Distribuição (em porcentagem) dos adolescentes (n=28) em função da freqüência de uso dos recursos informativos sobre carreiras, em dois momentos da intervenção (pré e pós).

\begin{tabular}{llll}
\hline $\begin{array}{l}\text { Recursos } \\
\text { utilizados }\end{array}$ & Freqüência & Pré-intervenção \% & Pós-intervenção \% \\
\hline Internet & Nunca/ raramente & 32,2 & 10,7 \\
& Às vezes & 32,1 & 32,1 \\
Guias & Freqüentemente/ sempre & 35,8 & 57,1 \\
& Nunca/ raramente & 51,8 & 46,4 \\
& Às vezes & 29,6 & 28,6 \\
Livros & Freqüentemente/ sempre & 18,5 & 25,0 \\
& Nunca/ raramente & 60,7 & 67,8 \\
\multirow{4}{*}{ Revistas } & Às vezes & 28,6 & 25,0 \\
& Freqüentemente/ sempre & 10,7 & 7,2 \\
\multirow{2}{*}{ Programas } & Nunca/ raramente & 28,6 & 32,1 \\
TV & Às vezes & 46,4 & 42,9 \\
\multirow{2}{*}{ Programas } & Freqüentemente/ sempre & 25,0 & 25,0 \\
rádio & Nunca/ raramente & 35,7 & 32,2 \\
& Às vezes & 32,1 & 39,3 \\
Filmes & Freqüentemente/ sempre & 32,2 & 28,5 \\
& Nunca/ raramente & 60,7 & 92,9 \\
& Às vezes & 10,7 & 3,6 \\
& Freqüentemente/ sempre & 3,6 & 3,6 \\
\hline & Nunca/ raramente & 69,3 & 50,0 \\
& Às vezes & 19,2 & 28,6 \\
& Freqüentemente/ sempre & 11,5 & 21,5 \\
\hline
\end{tabular}


Indubitavelmente a internet é o instrumento mais utilizado para a busca da informação, como aponta a vasta literatura, tanto antes como após a intervenção. Cumpre destacar que o material informativo impresso tem sido utilizado em menor proporção, o que era esperado, porém não desejado pelos educadores e orientadores no caso das publicações mais qualificadas, livros, por exemplo. A consulta aos guias apresenta um ligeiro aumento, mas ele não é significativo. Interessante observar que filmes, ainda que pouco utilizados, praticamente dobram após a intervenção, passando de 11,5\% para 21,5\%.

Nesse quesito, na comparação entre o sexo feminino e o masculino (Tabela 7), dois recursos impressos - os guias $(\mathrm{p}=0,04)$ e os livros $(\mathrm{p}=0,05)$ - apresentaram valores significativamente superiores no sexo feminino, na fase de pré-intervenção. Os dados mostram que antes da intervenção em Orientação Profissional as moças buscavam mais informação profissional por meio da leitura de informações impressas. A prática da leitura de livros, no contexto brasileiro, tem sido uma das vantagens para a aprovação nos vestibulares. Nesse grupo as moças, de partida, estão em vantagem neste quesito. Após a intervenção a busca em guias apresenta tendência à diferença significativa $(p=0,08)$ para as moças. Com relação ao uso de livros, vale destacar que após a intervenção a vantagem das moças sobre os rapazes na leitura de livros não se mantém, o que pode ser questionado em relação às respostas dadas na primeira aplicação.

Tabela 7 - Resultados descritivos da utilização dos recursos de guias e livros no início da intervenção, em função do sexo.

\begin{tabular}{llllll}
\hline $\begin{array}{l}\text { Recursos } \\
\text { utilizados }\end{array}$ & Sexo & Mediana & Média & $\begin{array}{l}\text { Desvio } \\
\text { padrão }\end{array}$ & $\begin{array}{l}\text { Mann- } \\
\text { Whitney }\end{array}$ \\
\hline Guias & Feminino & 3,00 & 3,17 & 1,34 & $\mathrm{p}=0,04^{*}$ \\
& Masculino & 2,00 & 2,07 & 0,96 & \\
Livros & Feminino & 3,00 & 2,75 & 1,29 & $\mathrm{p}=0,05^{*}$ \\
& Masculino & 2,00 & 1,81 & 0,75 & \\
\hline
\end{tabular}

$(*)$ diferença significativa

O uso maior da internet, seguido pelos guias, independentemente do sexo, predominou nesta amostra. Esses resultados permitem inferir que os outros instrumentos não se dirigem a este tipo de informação, ou se o fazem tem sido em menor proporção. Observa-se que este é um assunto que está presente em programas de televisão, por exemplo, cerca de um terço antes e depois obtêm informação via TV. Potenciais veículos informativos como livros e rádios têm sido pouco utilizados como fonte informativa sobre profissões, na perspectiva deste grupo de sujeitos, como mostram os registros dos comentários sobre o item investigado: 
"não procurei informações sobre as profissões"; "é melhor procurar sobre profissões em guias, revistas, lugar voltado para essa busca”. Por outro lado, alguns integrantes preferem a utilização da internet, "na internet é bem mais fácil de obter informações, nela existe um leque muito grande de opções”. A precariedade de recursos informativos pode ser observada tanto na busca por parte dos jovens (não procuram informações ou buscam o que é mais fácil), quanto na oferta de informações qualificadas.

Na questão 4.1. pergunta “Quais os sites que você mais acessa?” todos os sites citados nas respostas foram considerados e cotados, como mostra a Tabela 8.

Tabela 8 - Distribuição dos sites utilizados na internet pelos adolescentes $(n=28)$ no início e ao final da intervenção.

\begin{tabular}{lll}
\hline SITES & Pré- intervenção & Pós- intervenção \\
\hline Google & 11 & 15 \\
Orkut & 10 & 10 \\
Esportes & 2 & 2 \\
UOL & 4 & 8 \\
Terra & 2 & 2 \\
MSN & 3 & 7 \\
Hotmail & 3 & 1 \\
Faculdades & 2 & 4 \\
Vestibular & 2 & 4 \\
Música (Cifraclub) & 1 & 5 \\
Jogos & 1 & 3 \\
Guias & 0 & 3 \\
Notícias & 0 & 2 \\
Compras & 0 & 1 \\
Filmes & 0 & 1 \\
Não sei & 8 & 2 \\
\hline
\end{tabular}

Os sites mais utilizados são o Google (site de busca, http://www.google.com.br) e o Orkut (site de relacionamento social, http://www.orkut.com.br) tanto no início da intervenção em Orientação Profissional como no final. No início do grupo um resultado interessante foi o número de participantes $(\mathrm{n}=8)$ que declararam não saber os sites utilizados. Cabe perguntar se preferem omitir ou se navegam sem a preocupação em saber por onde. Os demais sites citados foram o Uol (Universo Online, portal de conteúdo e provedor pago de acesso à internet), MSN (Microsoft Service Network, vários serviços oferecidos pela Microsoft na internet), Hotmail (correio eletrônico gratuito de acesso pela web) e Sites de Faculdades. Mesmo que o grupo de Orientação Profissional possa ter incentivado a utilização da internet para a busca de 
informações profissionais, a tendência maior apontada pelos sites de preferência dos adolescentes mostra que acessam a internet mais para recreação.

Observa-se que os sites mais utilizados pelos adolescentes, antes e depois da intervenção, foram os de busca Google que pode ser utilizado com inúmeros objetivos e fornece resultados de busca de informações disponíveis na Web de uma forma organizada, e o Orkut que é uma comunidade online amplamente divulgado entre os adolescentes, uma rede social virtual com a qual é possível reencontrar e conhecer mais pessoas, com os mesmos hobbies e interesses, que procuram um relacionamento afetivo, amigos ou contatos profissionais, como uma forma de conhecer a vida alheia.

As respostas à pergunta: “Qual é o local de onde você mais acessa a internet?” (questão 4.2) serão apresentados na Tabela 9. Os dados evidenciam que a maioria dos participantes, 96,4\% (pré-grupo e pós-grupo), afirmam acessar a internet da própria residência (freqüentemente e sempre). O que mostra o perfil socioeconômico dos jovens deste grupo, com poder aquisitivo que permite ter e manter computadores. A outra opção de local de acesso para esses adolescentes é a casa de amigos, com uma utilização freqüentemente e sempre de 22,2\% no pré-grupo e de 28,6\% no pós-grupo.

Tabela 9 - Distribuição (em porcentagem) dos adolescentes (n=28) em função da freqüência dos locais de uso da internet, no início e ao final da intervenção.

\begin{tabular}{llll}
\hline Locais & Freqüência & Pré-intervenção \% & Pós-intervenção \% \\
\hline Casa & Nunca/ raramente & 3,6 & 0 \\
& Às vezes & 0 & 3,6 \\
\multirow{3}{*}{ Escola } & Freqüentemente/ sempre & 96,4 & 96,4 \\
& Nunca/ raramente & 64,3 & 50,0 \\
\multirow{2}{*}{ Trabalho } & Às vezes & 32,1 & 46,4 \\
& Freqüentemente/ sempre & 3,6 & 3,6 \\
\multirow{2}{*}{ Trabalho } & Nunca/ raramente & 92,8 & 92,8 \\
pais & Às vezes & 7,1 & 3,6 \\
& Freqüentemente/ sempre & 0 & 3,6 \\
Lan house & Nunca/ raramente & 89,2 & 82,2 \\
& Às vezes & 3,6 & 17,9 \\
\multirow{2}{*}{ Casa de amigos } & Freqüentemente/ sempre & 7,2 & 0 \\
& Nunca/ raramente & 75,0 & 78,6 \\
\multirow{2}{*}{ Acesso público } & Às vezes & 10,7 & 21,4 \\
& Freqüentemente/ sempre & 14,3 & 0 \\
& Nunca/ raramente & 25,9 & 14,2 \\
& Às vezes & 51,9 & 57,1 \\
& Freqüentemente/ sempre & 22,2 & 28,6 \\
& Ànca/ raramente & 100 & 92,8 \\
& Freqüentemente/ sempre & 0 & 3,6 \\
& & 0 & 3,6 \\
\hline
\end{tabular}


Sobre o uso da internet na casa de amigos (Tabela 10), a comparação entre os sexos masculino e feminino, após a intervenção grupal de Orientação Profissional, apresentou diferença significativa $(p=0,05)$. O sexo feminino apresenta valores significativamente superiores.

Tabela 10 - Resultados descritivos quanto ao uso da internet na casa de amigos, ao final da intervenção, em função do sexo.

\begin{tabular}{llllll}
\hline Locais de acesso & Sexo & Mediana & Média & $\begin{array}{l}\text { Desvio } \\
\text { padrão }\end{array}$ & $\begin{array}{l}\text { Mann- } \\
\text { Whitney }\end{array}$ \\
\hline Casa de amigos & Feminino & 3,00 & 2,75 & 0,75 & $\mathrm{p}=0,05^{*}$ \\
& Masculino & 3,00 & 3,31 & 0,79 & \\
\hline
\end{tabular}

$(*)$ diferença significativa

As demais formas de acesso à internet, como: a escola, o trabalho, o trabalho dos pais, as lan houses e o acesso público, são pouco utilizados. Essa pergunta reflete a situação socioeconômica da população que faz parte deste estudo, cuja maioria tem acesso à internet na própria casa ou na casa dos amigos. Mesmo sendo a maioria dos adolescentes oriundos de escolas particulares, nelas eles praticamente não utilizam a internet. Essa informação é surpreendente, pois as propagandas das escolas informam sobre a existência de aulas de informática. As escolas, de fato, não dispõem de espaço para tal atividade na grade curricular? Ou a amostra deste estudo não interessa? Apenas um (1) aluno se refere à utilização da internet na escola, sendo às vezes no início da intervenção e freqüentemente ao final. Os adolescentes deste estudo em sua maioria não trabalham e, também, não fazem uso da internet no local de trabalho dos pais, o que era esperado. A prática clínica mostra que isto pode ocorrer quando os pais são proprietários de empresas ou funcionários que eventualmente levam seus filhos ao local de trabalho.

O acesso público à internet é desconhecido pela maior parte desses adolescentes, provavelmente por existirem poucos lugares disponíveis, mas também não existe essa demanda já que a maioria pode acessar da própria casa. Esses resultados confirmam os dados obtidos na pesquisa realizada pela MTV Brasil, Dossiê Universo Jovem de 2005, que mostram que os jovens da classe A (96\%) e da classe C (53\%) têm o próprio computador e, portanto, o seu acesso regular à internet. Eles, em sua maioria, estão conectados à internet, cuja utilização cresceu proporcionalmente, tanto para a classe A como para as demais classes, mas importa refletir em que medida esse crescimento se deu graças aos recursos próprios da 
população ou por incentivos de programas públicos que disponibilizassem financiamento para famílias de baixa renda.

“Com quais objetivos os jovens acessam a internet?” é a questão 4.3, cujas respostas a essa questão mostram o predomínio do acesso visando comunicar-se com colegas (Tabela 11), seguido da resposta de realizar pesquisa escolar e de buscar informações gerais, o que era esperado, mas não desejado em função da faixa etária e devido ao fato de os colegas e a escola constituírem o universo do adolescente. Uma das principais tarefas e exigências, no âmbito social e psicológico, dos jovens nessa etapa do seu desenvolvimento é: estudar e construir sua identidade pessoal. Uma das formas utilizadas por esses jovens parece decorrer das relações com os outros, estabelecidas via internet.

Tabela 11 - Distribuição (em porcentagem) dos adolescentes (n=28) em função da freqüência dos objetivos com que acessa a internet, no início e ao final da intervenção.

\begin{tabular}{|c|c|c|c|}
\hline Objetivos & Freqüência & Pré-intervenção \% & Pós-intervenção \% \\
\hline \multirow[t]{3}{*}{ Jogar } & Nunca/ raramente & 66,6 & 64,3 \\
\hline & Às vezes & 22,2 & 21,4 \\
\hline & Freqüentemente/ sempre & 11,1 & 14,3 \\
\hline \multirow{3}{*}{$\begin{array}{l}\text { Realizar pesquisa } \\
\text { escolar }\end{array}$} & Nunca/ raramente & 10,7 & 10,7 \\
\hline & Às vezes & 42,9 & 42,9 \\
\hline & Freqüentemente/ sempre & 46,4 & 46,4 \\
\hline \multirow{3}{*}{$\begin{array}{l}\text { Comunicar-se } \\
\text { colegas }\end{array}$} & Nunca/ raramente & 10,7 & 3,6 \\
\hline & Às vezes & 10,7 & 3,6 \\
\hline & Freqüentemente/ sempre & 78,6 & 92,8 \\
\hline \multirow[t]{3}{*}{ Fazer compras } & Nunca/ raramente & 89,3 & 85,7 \\
\hline & Às vezes & 10,7 & 14,3 \\
\hline & Freqüentemente/ sempre & 0 & 0 \\
\hline Fazer novos & Nunca/ raramente & 53,6 & 67,8 \\
\hline \multirow[t]{2}{*}{ relacionamentos } & Às vezes & 14,3 & 17,9 \\
\hline & Freqüentemente/ sempre & 32,3 & 14,3 \\
\hline \multirow{3}{*}{$\begin{array}{l}\text { Buscar informações } \\
\text { gerais }\end{array}$} & Nunca/ raramente & 22,2 & 10,7 \\
\hline & Às vezes & 37,0 & 32,1 \\
\hline & Freqüentemente/ sempre & 40,7 & 57,1 \\
\hline \multirow{3}{*}{$\begin{array}{l}\text { Buscar informações } \\
\text { sobre profissões }\end{array}$} & Nunca/ raramente & 42,9 & 25,0 \\
\hline & Às vezes & 39,3 & 39,3 \\
\hline & Freqüentemente/ sempre & 17,9 & 35,7 \\
\hline \multirow{3}{*}{$\begin{array}{l}\text { Buscar informações } \\
\text { sobre universidades }\end{array}$} & Nunca/ raramente & 53,6 & 46,4 \\
\hline & Às vezes & 32,1 & 28,6 \\
\hline & Freqüentemente/ sempre & 14,3 & 25,0 \\
\hline
\end{tabular}

A tendência em utilizar predominantemente a internet para comunicar-se com colegas, ou seja, para recreação e depois para pesquisas escolares, corroborou os achados de HENRIQUES (2003). Considerando que os resultados da questão 4.1 indicam que os sites 
mais utilizados são o Google e o Orkut, conclui-se que a internet é mais utilizada como divertimento e menos com o objetivo de auxiliar o jovem na busca de informações referentes à sua escolha profissional. Com isso esses jovens utilizam a internet para buscar informações variadas, porém deixam de usá-la como ferramenta bastante rica para obter informações sobre as profissões e os mecanismos de ingresso na universidade, o que poderia auxiliá-los no processo de escolha profissional. A questão é por que não utilizam esse recurso mesmo tendo internet na própria casa? Por falta de conhecimento dos endereços na internet? Por imaturidade na escolha profissional? Por falta de orientação mediada por um profissional especializado?

Nas comparações entre o sexo feminino e o masculino, algumas diferenças significativas foram observadas quanto aos objetivos de jogar, realizar pesquisa escolar e de buscar informações sobre profissões. Quem acessa mais a internet? A Tabela 12 mostra que no início da intervenção (pré-grupo) as moças realizam significativamente mais pesquisas escolares na internet do que os rapazes.

Tabela 12 - Resultados descritivos sobre o uso da internet para a realização de tarefas escolares no início da intervenção, em função do sexo.

\begin{tabular}{|c|c|c|c|c|c|c|}
\hline Objetivos & & Sexo & Mediana & Média & $\begin{array}{l}\text { Desvio } \\
\text { padrão }\end{array}$ & $\begin{array}{l}\text { Mann- } \\
\text { Whitney }\end{array}$ \\
\hline Realizar & pesquisa & Feminino & 4,00 & 3,92 & 0,79 & $\mathrm{p}=0,04^{*}$ \\
\hline escolar & & Masculino & 3,00 & 3,06 & 1,06 & \\
\hline
\end{tabular}

(*) diferença significativa

Por sua vez, os dados apresentados na Tabela 13 mostram diferenças significativas, na medida pós-intervenção, em dois outros objetivos pelos quais os jovens acessam a internet - o de jogar e o de buscar informações sobre profissões. Com o objetivo de jogar os rapazes apresentam uma diferença significativamente superior, o que reforça o interesse dos rapazes por jogos, sobretudo os eletrônicos. Quanto ao objetivo de buscar informações sobre as profissões na comparação após a intervenção em Orientação Profissional, as moças apresentam valores significativamente superiores em relação aos rapazes. Ao considerarmos todos esses resultados parece que as moças tendem a comportamentos e atitudes mais relevantes para a escolha da profissão e, portanto, mais maduros, o que aponta na direção dos achados de Lobato e Koller (2003), que relatam que as moças buscam mais informações sobre o mundo do trabalho, planejando conseqüentemente melhor as suas carreiras. 
Tabela 13 - Resultados descritivos sobre o uso da internet para jogar e buscar informações sobre a carreira, ao final da intervenção, em função do sexo.

\begin{tabular}{llllll}
\hline Objetivos & Sexo & Mediana & Média & D.padrão & $\begin{array}{l}\text { Mann- } \\
\text { Whitney }\end{array}$ \\
\hline Jogar & Feminino & 1,00 & 1,67 & 0,98 & $\mathrm{p}=0,04^{*}$ \\
& Masculino & 2,50 & 2,56 & 1,15 & \\
Buscar informações & Feminino & 4,00 & 3,67 & 0,89 & $\mathrm{p}=0,02^{*}$ \\
sobre as profissões & Masculino & 3,00 & 2,81 & 0,75 & \\
\hline
\end{tabular}

(*) diferença significativa

Nas comparações entre os resultados obtidos no início e ao final da intervenção (Tabela 14), algumas diferenças foram detectadas quanto aos objetivos de acessar a internet para: fazer novos relacionamentos, buscar informações sobre as profissões e buscar informações sobre universidades.

Tabela 14 - Resultados descritivos do uso da internet para fazer novos relacionamentos, buscar informações sobre as profissões e universidade, em função da avaliação, no início e ao final da intervenção.

\begin{tabular}{|c|c|c|c|c|c|c|}
\hline \multicolumn{2}{|l|}{ Objetivos } & Intervenção & Mediana & Média & $\begin{array}{l}\text { Desvio } \\
\text { padrão }\end{array}$ & $\begin{array}{l}\text { Mann- } \\
\text { Whitney }\end{array}$ \\
\hline \multirow{2}{*}{$\begin{array}{l}\text { Fazer } \\
\text { relacionamentos }\end{array}$} & \multirow[t]{2}{*}{ novos } & Pré & 2,00 & 2,71 & 1,46 & $\mathrm{p}=0,02^{*}$ \\
\hline & & Pós & 2,00 & 2,04 & 0,70 & Pré>Pós \\
\hline \multirow{2}{*}{$\begin{array}{l}\text { Buscar informações } \\
\text { profissões }\end{array}$} & \multirow{2}{*}{ sobre } & Pré & 3,00 & 2,61 & 1,07 & $\mathrm{p}=0,01^{*}$ \\
\hline & & Pós & 3,00 & 3,18 & 0,90 & Pós > Pré \\
\hline \multirow{2}{*}{$\begin{array}{l}\text { Buscar informações } \\
\text { universidades }\end{array}$} & \multirow{2}{*}{ sobre } & Pré & 2,00 & 2,36 & 1,13 & $\mathrm{p}=0,05^{*}$ \\
\hline & & Pós & 3,00 & 2,71 & 0,94 & Pós > Pré \\
\hline
\end{tabular}

(*) diferença significativa

O quesito acessar a internet para fazer novos relacionamentos diminuiu, após intervenção, nas categorias freqüentemente e sempre (32,3 \% antes e 14,3\% depois), p=0,02 (Tabelas 11 e 14) e aumentou nas categorias nunca e raramente (53,6\% antes e 67,8\% depois), como mostra a Tabela 11. Nesse item é importante considerar que enquanto que o acesso aos sites de relacionamento diminuiu houve aumento no uso para fins de pesquisas sobre as profissões e universidades.

A busca de informações sobre as profissões e as universidades por meio da internet apresentou diferença significativa quanto ao aumento do acesso ao final da intervenção, o que era esperado, uma vez que esse foi um dos objetivos da intervenção, tendo em vista a 
necessidade do adolescente em reunir o maior número possível de informações acadêmicas e profissionais a fim de realizar a escolha profissional autônoma e consciente. A comparação dos resultados mostrou que os adolescentes passaram a buscar mais informações sobre profissões e universidades no final do processo, sinalizando que o processo grupal alcançou seus objetivos para a busca de mais informações. A intervenção face a face aliada ao uso de guias e computadores se mostrou eficaz.

Esses dados sugerem consonância com a literatura apresentada anteriormente (GUICHARD; HUTEAU, 2001, REILE; HARRIS-BOWLSBEY, 2000, NILES; HARRISBOWLSBEY, 2005), isto é, os métodos tradicionais e os novos recursos tecnológicos podem ser utilizados como complemento a fim de promover melhor desempenho do orientador com um melhor aproveitamento do adolescente.

“Quantas vezes por semana e qual a média de horas por dia que utilizam a internet para buscar informação profissional?” é a questão 4.4. No início da intervenção a internet é utilizada de uma a duas vezes por semana por 50\% dos adolescentes e de três a quatro vezes por 16,6\% deles. Ao final do processo de intervenção, 78,5\% deles relataram utilizar uma a duas vezes por semana. Quanto ao número de horas tanto no início quanto no final do grupo de Orientação Profissional, $54,2 \%$ deles responderam permanecer de uma a duas horas conectados e 16,7\% de três a quatro horas. Cumpre destacar que essa resposta corresponde provavelmente mais ao uso geral da internet com objetivos variados do que exclusivamente ao tempo gasto em buscar informações sobre profissões e universidades, como consta nessa questão.

A questão 5 indaga sobre as "preferências em relação à(s) profissão(ões) que desperta(m) mais o interesse do jovens”. Os resultados apresentados na Tabela 15 mostram as carreiras citadas, aqui categorizadas em quatro grandes áreas, conforme explicitado no método, na seção procedimento da análise. Na área de Exatas os jovens citaram mais profissões na primeira aplicação do questionário (42,8\%) enquanto que ao final diminuiu a opção (25\%) por algum curso dessa área, com a diferença significativa de p=0,04. As áreas de Humanidades (67,8\% antes e 60,6\% depois) de Biológicas (42,9 antes e 35,7 depois) também diminuem, embora sem diferença significativa. Isso significa que o leque de opções se restringiu no final do processo de intervenção, sinalizando tomada de decisão facilitada pela intervenção em Orientação Profissional.

Por sua vez, os cursos Técnicos são os que menos despertaram interesse (3,6\% antes). Ainda que se observe baixa preferência desde o início, as citações aumentaram (7,1\% depois). Parece que os adolescentes preferem carreiras que demandem cursos universitários, o que é esperado no Brasil em função do desprestígio das carreiras técnicas e tecnológicas. 
Tabela 15 - Distribuição (em porcentagem) dos adolescentes (n=28) na comparação entre os resultados no início e ao final da intervenção, em função das áreas de interesse.

\begin{tabular}{llll}
\hline Áreas & Pré- intervenção $\%$ & Pós- intervenção $\%$ & Wilcoxon \\
\hline Exatas & 42,8 & 25 & $\mathrm{p}=0,04 *$ \\
Humanidades & 67,8 & 60,6 & $\mathrm{p}=0,66$ \\
Biológicas & 42,9 & 35,7 & $\mathrm{p}=0,16$ \\
\hline Técnico & 3,6 & 7,1 & $\mathrm{p}=0,32$ \\
\hline
\end{tabular}

(*) diferença significativa

No início da intervenção em Orientação Profissional, a maioria dos adolescentes citou profissões de duas e até das três áreas, demonstrando a situação de indecisão em que se encontram nesse início de processo de escolha profissional.

Na pergunta aberta “o que sabem sobre essas profissões?” (questão 5.1), as respostas foram organizadas em três categorias: (1) "não sei” ou "nada”, (2) "pouca informação” e (3) “alguma informação”. No início da intervenção 17,9\% dos jovens responderam "não sei”, 75\% que sabem “pouco" e 7,1\% têm “alguma informação”. Os textos mostravam respostas esparsas e de pouco conteúdo. Na avaliação ao final da intervenção 10,7\% dos jovens responderam “não sei”, 28,6\% que sabem “pouco” e 60,7\% responderam ter "alguma informação". Observou-se diferença significativa entre os dois momentos $\mathrm{p}<0,001$ (Tabela 16). As respostas à segunda aplicação do questionário mostraram mais conteúdos informativos, evidenciando um aumento no conhecimento sobre as profissões de seu interesse, o que mostra mais uma vez a importância da implementação de Programas de Orientação Profissional face a face.

Tabela 16 - Resultados descritivos sobre o quanto os jovens têm de informação sobre as profissões (categoria 3), em função do momento, no processo de intervenção.

\begin{tabular}{|c|c|c|c|c|}
\hline $\begin{array}{ll}\begin{array}{l}\text { Alguma } \\
\text { (categoria 3) }\end{array} & \text { informação } \\
\end{array}$ & Mediana & Média & D.padrão & Wilcoxon \\
\hline Pré- intervenção & 1,00 & 0,89 & 0,50 & $\mathrm{p}<0,001^{*}$ \\
\hline Pós- intervenção & 2,00 & 1,50 & 0,69 & \\
\hline
\end{tabular}

(*) diferença significativa 
As informações sobre as profissões e as universidades constituem passos fundamentais para a decisão sobre a carreira a ser seguida. Um importante aspecto comentado nessa questão, por alguns adolescentes, é que pelo fato de estarem com muita dúvida sobre a escolha e pela grande quantidade de opções, não se motivavam a buscar informações. Sabe-se que pessoas em situação de indecisão apresentam resistência à busca de informações, pois os conteúdos dos materiais informativos, pela quantidade e variedade, aumentariam o grau de ansiedade característico dessa situação. Por esta razão, para tais pessoas, os programas de Orientação Profissional presenciais são mais adequados, pois com a ajuda do orientador à medida que os obstáculos epistemofilicos (relacionados à emoção, à ansiedade) são trabalhados na intervenção, fica mais fácil lidar com os conteúdos informativos e todos os aspectos afetivo-emocionais que eles desencadeiam.

Como citado anteriormente, o orientador deverá ter clareza sobre a prontidão da pessoa para receber a informação via computador e aplicá-la efetivamente, segundo destaca Niles e Harris-Bowlsbey (2005), uma das responsabilidades do orientador profissional no processo de desenvolvimento de carreira. Nesse estudo o papel do orientador foi o de estimular o uso da ferramenta e os dados sinalizam as vantagens desse tipo de intervenção.

A questão 5.2: “como obteve tais informações?” não foi analisada isoladamente porque todos os dados das respostas dos adolescentes se referiam a alguma das pessoas anunciadas na questão 5.4. Foi investigado na questão 5.3 se o adolescente busca (ou buscou) informação com alguma pessoa ou não. A maioria respondeu que sim tanto no pré-grupo (78,6\%) quanto no pós-grupo (85,7\%), o que evidencia que existe uma preferência em buscar informações por meio de relações interpessoais.

Em seguida investigou-se por meio da (questão 5.4.), “com quem os adolescentes têm obtido informações sobre as profissões?” (Tabela 17). 
Tabela 17 - Distribuição (em porcentagem) dos adolescentes (n=28) segundo a fonte de informações, no início e ao final da intervenção.

\begin{tabular}{llll}
\hline Fonte & Freqüência & Pré- intervenção \% & Pós- intervenção \% \\
\hline Colegas & Nunca/ raramente & 31,8 & 37,5 \\
& Às vezes & 40,9 & 20,8 \\
\multirow{3}{*}{ Professores } & Freqüentemente/ sempre & 27,2 & 41,7 \\
& Nunca/ raramente & 33,3 & 20,9 \\
& Às vezes & 28,6 & 41,7 \\
Familiares & Freqüentemente/ sempre & 38,1 & 37,5 \\
& Nunca/ raramente & 4,8 & 8,3 \\
& Às vezes & 47,6 & 37,5 \\
\multirow{4}{*}{ Religiosos } & Freqüentemente/ sempre & 47,7 & 54,2 \\
& Nunca/ raramente & 100 & 100 \\
& Às vezes & 0 & 0 \\
Profissionais & Freqüentemente/ sempre & 0 & 0 \\
& Nunca/ raramente & 71,4 & 50,0 \\
& Às vezes & 14,3 & 20,8 \\
\multirow{2}{*}{ Serviços de OP } & Freqüentemente/ sempre & 14,3 & 29,2 \\
& Nunca/ raramente & 66,7 & 16,6 \\
& Às vezes & 19,0 & 12,5 \\
& Freqüentemente/ sempre & 14,3 & 70,9 \\
\hline
\end{tabular}

As respostas na avaliação pré-intervenção mostram o predomínio, nas categorias freqüentemente e sempre, dos familiares $(47,7 \%)$ e dos professores $(38,1 \%)$ na tarefa de informação profissional fornecida aos jovens. Um dos aspectos a ser considerado na busca da informação profissional é o predomínio na obtenção da informação profissional via pessoas mais próximas afetivamente (familiares e professores) com quem têm de alguma forma um vínculo, seja em casa ou na escola, resultado evidenciado na avaliação pré -intervenção, como apontado anteriormente.

Em relação aos familiares as consultas continuam sendo feitas, porém não são significativas porque já era elevada na situação pré-intervenção (47,7\% antes e 54,2\% depois, nas categorias freqüentemente e sempre). A literatura aponta a importância da família na definição da carreira de seus filhos, constituindo objeto de estudo em diferentes autores como: Bohoslavsky (1971), Niles (1997), Levenfus e Soares (2002), Melo-Silva, L.L.; Jacquemin (2001), Loosli (2003) e Hutz; Bardagir (2006), entre outros. O momento da escolha profissional sinaliza, para toda a família, um momento de diferenciação do jovem que se aproxima cada vez mais do mundo adulto e necessita realizar escolhas de forma independente e autônoma. Aos pais cabe encorajar os filhos a pensarem criticamente, favorecendo o diálogo 
e aceitando que os mesmos escolham caminhos diferentes dos seus, inclusive podendo construir projetos de vida diferentes das expectativas dos pais.

No final da intervenção em Orientação Profissional há crescimento no fornecimento de informações por parte dos colegas, passando de 27,2\% para 41,7\%, provavelmente porque a vivência em grupo estimula a troca de informações com os pares. Mas o maior aumento é na informação fornecida pelo SOP, passando de 14,3 para 70,9 ( $\mathrm{p}=0,001$, Tabela 18).

Tabela 18 - Resultados descritivos, na comparação entre o início e o final da intervenção, em função do fornecimento da informação pelos Serviços de Orientação Profissional.

\begin{tabular}{lllll}
\hline Serviços de OP & Mediana & Média & D.padrão & Wilcoxon \\
\hline Pré- intervenção & 1,00 & 2,00 & 1,26 & $\mathrm{p}=0,001^{*}$ \\
Pós- intervenção & 4,00 & 3,50 & 1,02 & \\
\hline
\end{tabular}

(*) diferença significativa

O aumento significativo na oferta de informações fornecidas pelos Serviços de Orientação Profissional, comparando-se as avaliações pré e pós-intervenção, reforça a importância de se disponibilizar tais serviços à comunidade. Em especial, neste estudo, podese concluir que a experiência grupal foi uma possibilidade positiva na construção de um espaço no qual se pode refletir criticamente sobre as informações úteis para a tomada de decisão.

Neste campo existe muito a ser conquistado pelos profissionais da Orientação Profissional no Brasil para auxiliar esse jovem, como a criação de serviços especializados de iniciativa tanto pública quanto privada, onde adolescentes e adultos possam buscar informações profissionais com a utilização de recursos variados como vídeos, jornais, livros e os vários programas computacionais. Segundo Niles e Harris-Bowlsbey (2005), como o número de carreiras e ocupações é muito grande, torna-se impossível para muitos adolescentes aprender individualmente a elaborar um planejamento de carreira de uma forma organizada. Para tanto, é fundamental a introdução do papel do orientador profissional, no contato com esse jovem, como mediador entre as referências afetivas de familiares, professores e colegas que o influenciam no planejamento de carreira, com informações precisas sobre as profissões e mercado de trabalho disponíveis em diferentes formatos de instrumentos (impresso, digital, entre outros). Também cumpre destacar a importância de oferecer serviços diversificados em função do tempo de duração e das demandas, presenciais ou virtuais. 
A questão 6 investiga o que os adolescentes sabem sobre as seguintes formas de acesso à Universidade: Vestibular, Exame Nacional do Ensino Médio (ENEM), Sistemas de Cotas, Programa Universidade para todos (ProUni) e outros processos seletivos. A Tabela 19 mostra a distribuição das respostas, organizadas em três categorias, sobre o que os jovens sabem sobre as formas de acesso à universidade.

Tabela 19 - Distribuição das respostas (em porcentagem) sobre a natureza do conhecimento dos adolescentes $(n=28)$ e as formas de acesso à Universidade, no início e ao final da intervenção.

\begin{tabular}{|c|c|c|c|}
\hline $\begin{array}{l}\text { Formas } \\
\text { acesso }\end{array}$ & Categorias & $\begin{array}{l}\text { Pré- } \\
\text { Intervenção \% }\end{array}$ & $\begin{array}{l}\text { Pós- } \\
\text { intervenção \% }\end{array}$ \\
\hline \multirow[t]{3}{*}{ Vestibular } & 1. Não sei & 14,3 & 4,0 \\
\hline & 2. Atividade competitiva & 28,6 & 32,0 \\
\hline & 3. Avaliação/ prova & 51,1 & 64,0 \\
\hline \multirow[t]{3}{*}{ ENEM } & 1.Não sei & 21,4 & 4,0 \\
\hline & 2. Avalia o EM/ aluno & 42,9 & 28,0 \\
\hline & 3. Ajuda na nota/ auto-avaliação & 35,7 & 68,0 \\
\hline \multirow[t]{3}{*}{ Sistema de Cotas } & 1. Não sei & 53,6 & 29,2 \\
\hline & 2. Pouco & 10,7 & 16,7 \\
\hline & 3. Número de vagas reservadas... & 35,7 & 54,2 \\
\hline \multirow[t]{3}{*}{ PROUNI } & 1. Não sei & 46,4 & 24,0 \\
\hline & 2. Alguma informação & 10,7 & 28,0 \\
\hline & 3. Estudantes baixa renda... & 42,9 & 48,0 \\
\hline Outros processos & 1. Não sei & 82,1 & 69,6 \\
\hline \multirow{2}{*}{ seletivos } & 2. Informação incorreta & 7,1 & 8,7 \\
\hline & 3. Alguma informação & 10,7 & 21,7 \\
\hline
\end{tabular}

As respostas ao quesito Vestibular foram categorizadas em: (1) "não sei” ou "pouca informação”, (2) “atividade competitiva” e (3) "avaliação” ou "prova”. Somente 14,3\% dos adolescentes registraram não saber o que era o Vestibular, diferindo entre eles a forma como normalmente compreendem e encaram o desafio da seleção, como será visto posteriormente.

Muitos jovens aspiram ao ingresso em uma boa faculdade, de preferência em universidades públicas e carreiras de prestígio. A universidade é um sonho almejado e para alcançá-lo é preciso transpor a barreira do Vestibular. Decidir-se por uma carreira universitária leva a pensar no Vestibular e na relação candidato-vaga. Vestibular, na visão dos jovens, é sinônimo de avaliação, prova, competição, o que pode elevar a ansiedade para a escolha da carreira e muitas vezes dificultar a busca de informações sobre as possibilidades de acesso à universidade e o que significa cada uma das alternativas investigadas nos itens subseqüentes, sobre o ENEM, o Programa de Cotas e o ProUni. Independentemente da 
definição de cada um o Vestibular parece ser compreendido como um processo seletivo, no qual a maioria dos vestibulandos será excluída. Para Sarriera; Schiessl (2004), a discussão sobre o Vestibular passa necessariamente por toda a interferência que o mesmo provoca na vida e no processo de escolha profissional desses jovens, sendo impossível desvincular o Vestibular da escolha do curso universitário principalmente por ser a forma de ingresso mais utilizada atualmente, no Brasil.

As respostas acerca do ENEM foram categorizadas em: (1) "não sei” ou "pouca informação”, (2) “avalia o Ensino Médio e/ ou o aluno”, e (3) “ajuda na nota do aluno para ingressar em uma universidade ou auto-avaliação”. Na comparação entre o pré-grupo e pósgrupo há diferença significativa $(\mathrm{p}=0,02)$ na categoria 3 “ajuda na nota do aluno para ingressar em uma universidade ou auto-avaliação” com aumento dessas respostas no momento final da intervenção em Orientação Profissional.

Os adolescentes, ao final da intervenção têm mais informações sobre o ENEM. Algumas possibilidades podem ser levantadas, O ENEM é a política pública há mais tempo implementada dentre as demais formas de acesso à universidade e a que todo aluno cursando o Ensino Médio pode realizar, independendo da escola de procedência, situação econômica ou raça.

As respostas categorizadas no Sistema de Cotas foram: (1) “não sei”, (2) "pouca informação”, e (3) “número de vagas para negros”. Nessa forma de acesso é grande a falta de informação sobre as políticas de ação afirmativa que subsidiam os programas de cotas universitárias e as universidades que já contêm tais programas. As ações Afirmativas têm como objetivo promover o acesso a meios fundamentais de sobrevivência digna, como educação e trabalho, a minorias étnicas, raciais ou sexuais. No contexto da Educação Superior elas estão sendo discutidas e em várias universidades foram implantadas por meio de Programas de Cotas. (GUARNIERI; MELO-SILVA, 2007, GUARNIERI, 2008). Como uma medida alternativa para o ingresso na universidade existem grupos que poderão ser beneficiados. Assim sendo, supõe-se que esse assunto deveria ser do interesse da maioria dos vestibulandos, porém não é o que foi observado na opinião dos participantes deste estudo. Nos comentários registrados, muitas das argumentações diziam respeito ao desinteresse neste sentido, enquanto que outros ressaltavam a polêmica discussão a favor ou contra as medidas de ação afirmativa. O Sistema de Cotas em vigor desde 2001 gera um debate acirrado por parte de alguns enquanto que outros demonstram indiferença, por falta de informação, ou receio quanto à complexidade do tema. 
Relativamente às informações sobre o ProUni as respostas foram categorizadas em: (1) “não sei”, (2), “alguma informação”, e (3) “um meio de estudante de baixa renda adquirir bolsa”. No início da intervenção em Orientação Profissional 46,4\% não sabiam informar do que se tratava o ProUni e, essa porcentagem diminuiu para $24 \%$ ao final da intervenção em Orientação Profissional.

O ProUni foi criado em 2005 e pode ser desconhecido em parte pelos jovens por ser uma política pública recentemente implantada. Muitos nessa questão comentaram não buscar mais informações por não terem direito ao benefício. Nesse item diferente da questão anterior sobre o Sistema de Cotas, todos os que fizeram algum comentário elogiaram a iniciativa do Governo brasileiro de auxiliar quem não tem condições de ingressar em uma Universidade Pública e assim ter a oportunidade de estudar em uma universidade particular por meio de um programa financiado pelo governo.

No último item da questão 6, a pergunta indagava sobre outros processos seletivos, e as respostas foram categorizadas em: (1) “não sei”, (2) “informação incorreta” ou (3) "alguma informação”. Nessa questão é grande (82,1\% pré-grupo e 69,6\% pós-grupo) o número de adolescentes que desconhecem outras formas de acesso à universidade, que respondem "não sei”, demonstrando que a grande maioria desconhece outros processos seletivos, o que se repete na comparação pré e pós-intervenção. Esse dado pode ser atribuído à falta de interesse em optar por outra forma de acesso, mas também pelo fato de ser dominante o acesso através do Vestibular na realidade brasileira atual.

“O que você conhece sobre inscrições para o Vestibular? E sobre taxa de isenção?” (questão 7). As respostas foram categorizadas em: (1) “não sei”, (2) “informações sobre inscrição”, e (3) “informações sobre a isenção da taxa de inscrição”. Na situação préintervenção 25\% dos participantes responderam "não sei”, 50\% responderam que "estão informados sobre o procedimento para a inscrição" e 25\% sobre a “isenção para alunos de baixa renda”, sobretudo, os provenientes de escolas pública e que podem comprovar baixa renda. Após a intervenção apenas a categoria (3) teve aumento, passando para 34,6\%. As duas primeiras categorias diminuíram após a intervenção (26,9\% não sei e 38,5\% têm informação sobre as inscrições). Nenhuma diferença é significativa. Porém, qualitativamente observou-se um paradoxo nas respostas a essa questão nas duas aplicações, uma vez que a análise dos comentários aponta precariedade das informações sobre as formas tradicionais e as alternativas de acesso às universidades. Os jovens informaram que preferiam buscar informações à medida que percebiam evidentemente a necessidade da mesma, isto é, após a decisão. Observa-se que a emergência não era a informação sobre o vestibular e sim a 
escolha. Outros alegaram ainda que não poderiam ser beneficiados pela taxa de isenção e por isso não tinham interesse em saber do que se trata. O que mudou após a intervenção foi a tomada de consciência sobre a importância das informações sobre o Vestibular.

Em relação à pergunta 8: "Você já verificou a relação candidato/ vaga de carreiras universitárias?” Nas respostas pré-intervenção 57,1\% dos adolescentes não verificavam a relação candidato/ vaga das carreiras pretendidas. Nessa fase de início do processo muitos justificavam nos comentários que o motivo de não verificar a relação candidato/ vaga era por não terem feito a escolha da profissão para a qual pretendiam prestar o vestibular, outros relatavam ainda que se sentiam tensos e angustiados caso fosse muito concorrido o curso escolhido. Ao final da intervenção de Orientação Profissional 60,7\% dos jovens afirmaram terem se informado a respeito. Houve um aumento na busca de informações sobre a relação candidato/ vaga, o que certamente auxilia a tomada de decisão de uma forma integrada e amparada em dados objetivos sobre as profissões e carreiras.

As respostas às questões 7 e 8 suscitam algumas reflexões sobre os obstáculos e dificuldades que terão que ser enfrentadas, também, para a busca da informação sobre o vestibular. É intenso o receio de enfrentar a angústia do novo - o mundo adulto e as possíveis dificuldades referentes à realidade brasileira, o que os leva a ignorar as informações profissionais, que possam aumentar a ansiedade, como uma estratégia de não enfrentamento ou de negação da situação. O grande receio desses adolescentes em seus comentários é o fato de ser o Vestibular muito concorrido o que dificulta a entrada em uma carreira de maior prestígio, sobretudo em universidades públicas, desejo da maioria dos jovens e de suas famílias. Sobre esse dado os jovens percebem o que os números revelam. Segundo Sarriera e Schiessl (2004) três em cada quatro alunos não podem estudar na Universidade por não ter o número de vagas suficiente para todos.

Na pergunta 9 “Que tipo de informação você tem sobre as oportunidades de trabalho no Brasil?”, as respostas foram categorizadas em: (1) “não sei”, (2) “pouca informação” e (3) “alguma informação”. Na avaliação antes da intervenção 14,3\% responderam não sei, 53,6\% que têm pouca informação e 32,1\% que têm alguma informação sobre as oportunidades do mercado de trabalho brasileiro. Após a intervenção 3,6\% dos participantes responderam não sei, 39,3\% que têm pouca informação e 57,1\% que têm alguma informação. As respostas a essa questão sinalizam maior satisfação dos respondentes com o grau de conhecimento das oportunidades no Brasil, observado nos exemplos citados e nas discussões sobre o tema.

Antes da intervenção a maioria considerou não ter (ou ter pouca) informação sobre o mercado de trabalho. As respostas evidenciam que poucos têm segurança e clareza sobre o 
tema, a maioria parece se prender a idéias pré-concebidas, como: “o mercado está concorrido”, “pequeno número de vagas”, “desemprego”, “só com muita qualificação”. No que se refere ao lado negativo da questão, o pessimismo dos jovens em relação às oportunidades de trabalho no Brasil foi um tema também abordado por Levenfus e Nunes (2002), que citam uma pesquisa da Unicef (1999), em vinte países da América Latina e Caribe, na qual o Brasil está em segundo lugar no ranking do pessimismo com 69\% das crianças e jovens brasileiros achando que a vida não vai melhorar atrás apenas da Colômbia. Na atualidade é importante verificar se esse estado se alterou com as novas medidas governamentais.

Um dos aspectos com que a maioria concorda é quanto à necessidade de ter mais informações profissionais. Após a intervenção as respostas indicam mais segurança dos respondentes. Ainda que o caráter pessimista permaneça em relação às oportunidades, conforme expressões: “difícil emprego”, “muito concorrido o mercado”, “desemprego”, após a intervenção uma minoria começa a vislumbrar “um bom mercado” de trabalho, com "várias oportunidades de emprego”, e para muitos deles “as oportunidades existem e são crescentes”. Sarriera e Schiessl (2004) apontam a restrição do mercado de trabalho como dificultador da tomada de decisão e traz incertezas sobre o futuro das profissões e do mercado de trabalho. Porém, "poucos empregos não significam necessariamente pouco trabalho, o que muda é a forma de relacionamento entre empresa e trabalhador” (SARRIERA; SCHIESSL, 2004, p.66).

Quanto à qualidade da informação profissional, a questão 10.1 do QIP aborda a opinião dos adolescentes sobre o proveito que têm tido com as informações procuradas. As respostas foram categorizadas em: (1) “não sei”, (2) “pouco e insuficiente proveito das informações profissionais”, e (3) “bom proveito das informações profissionais”. Os resultados antes da intervenção são: 7,4\% de “não sei”, 40,7\% de “pouco e insuficiente proveito das informações profissionais” e 51,9\% de "bom proveito das informações profissionais”. Após a intervenção as respostas são: $0 \%$ de “não sei”, 22,2\% de "pouco e insuficiente proveito das informações profissionais” e 77,8\% de “bom proveito das informações profissionais”. Houve um aumento por parte dos adolescentes no aproveitamento das informações profissionais buscadas, apresentando diferença significativa $(\mathrm{p}=0,04)$. Para que os recursos informativos sejam melhor aproveitados pelos jovens é importante o suporte de especialistas que os auxiliem a sistematizar e a lidar com as informações de forma que elas sejam úteis nos processos de decisão. A intervenção em Orientação Profissional, na perspectiva da Psicologia, focaliza exatamente a integração lógica e psicológica ou cognitiva e afetiva dos conteúdos sobre as carreiras. 
Como apontado anteriormente, vários autores (ESBROECK, 2002; NILES; HARRISBOWLSBEY, 2005; SAVICKAS; ESBROECK; HERR, 2005; WATTS, 2002) expressam preocupação quanto à qualidade das informações disponíveis nos sites de Orientação Profissional, referindo-se aos vários cuidados éticos que deveriam cercar a utilização da Internet nesse domínio. Entretanto, como salienta Savard (2002), muitos adolescentes estão encontrando dificuldade no manuseio das informações disponíveis na internet. O que demonstra a necessidade de entender que alguns adolescentes podem usufruir das informações de forma mais autônoma, enquanto outros ainda precisam de um suporte maior, como profissionais da Orientação Profissional que propiciem o desenvolvimento da maturidade profissional para a escolha de carreira, como aponta Sampson (1999).

Ainda quanto à qualidade da informação profissional o item 10.2. pergunta: “Ainda são necessárias outras informações?”, as respostas foram categorizadas em: (1) “não” e (2) “sim”. No início da intervenção em Orientação Profissional 81,5\% dos adolescentes consideraram ser necessárias outras informações acerca das profissões de interesse. Esses dados confirmam a importância dada à ajuda que as informações representam na escolha da profissão, referida na questão 2 ("Você acredita que a informação profissional pode ajudá-lo (a) na tomada de decisão vocacional?”), na qual todos os integrantes afirmaram acreditar que a informação profissional pode ajudá-los.

Ao final da intervenção em Orientação Profissional 63\% afirmaram necessitar de mais informações sobre as profissões, em relação ao início do grupo. Houve decréscimo dessa necessidade, entretanto o fato de estarem mais informados, refletindo mais sobre questões profissionais, introduziu-os em um campo onde percebem a importância de se conhecer cada vez mais uma profissão e o mercado de trabalho, o que leva indubitavelmente à necessidade de novas informações e de aprofundamento das obtidas a cada etapa do desenvolvimento da carreira. Como salienta Brown (2003), a cada etapa do processo de escolha, o jovem demandará necessidades diferentes, de informações mais gerais e amplas até informações mais específicas sobre as profissões.

As respostas à questão 11: “O que você deseja ser? Registre suas expectativas em relação ao seu futuro, ao seu projeto de vida” serão apresentadas em função dos grupos de intervenção (A e B), uma vez que há diferenças peculiares a cada um deles em função da própria constituição. Esses aspectos serão abordados mais amplamente no item sobre o processo grupal.

No Grupo A as respostas pré-intervenção à pergunta “o que você deseja ser?” foram organizadas em torno dos seguintes eixos temáticos: o desejo de ser bem-sucedido $(n=8)$, de 
trabalhar em algo que o deixe feliz $(\mathrm{n}=8)$, a necessidade de ter independência financeira $(\mathrm{n}=$ 7), o desejo de construir uma família, um lar $(n=5)$, a vontade de ser um profissional $(n=4)$ e de amar a profissão, realizando o trabalho com prazer $(n=4)$. Algumas das respostas são explicitadas a seguir: "eu quero fazer alguma coisa que eu tenha prazer e goste muito, para ir trabalhar feliz"; "espero que eu possa ser uma profissional bem sucedida e que eu ame a minha profissão, quero ser feliz com a minha família, independente e ter um lar"; "não sei, mas quero trabalhar em alguma coisa que gosto, sem depender de ninguém. Ganhar meu dinheiro e fazer o que tiver vontade".

O tema mais comum nas respostas do Grupo B à mesma questão, antes da intervenção, foi especificar o nome da profissão de interesse $(n=7)$. Esse tipo de resposta difere das do Grupo A que não chega a mencionar nenhuma profissão. Cumpre destacar que esses dados confirmam o perfil do Grupo B, constituído por jovens avaliados no grau de maturidade para a escolha profissional dentro da média.

Ainda no Grupo B citam: o desejo de ser um profissional bem sucedido e reconhecido entre seus pares, ou seja, um bom profissional $(n=6)$; a vontade de constituir uma família (n $=4)$ e a necessidade de adquirir estabilidade financeira $(n=2)$, o desejo de ter tranqüilidade ( $\mathrm{n}=1)$, dúvida sobre o futuro $(\mathrm{n}=1)$ e não sei $(\mathrm{n}=1)$. A seguir algumas respostas exemplificam a questão: "um profissional bem sucedido, com um bom emprego, com uma família e ser reconhecido"; "penso em fazer faculdade de Química, e trabalhar em algo relacionado, mas tenho receio se essa é a escolha certa, gosto muito da matéria, mas tenho dúvidas”; “bem sucedido e feliz em uma profissão, podendo levar a vida com tranqüilidade e proveito".

Ao se referirem às oportunidades de trabalho no Brasil as respostas tiveram em sua maioria conotação pessimista, enquanto que nessa última questão quanto ao projeto de vida, a maioria das respostas foram mais otimistas, valorizando aspectos positivos da vida profissional, como: ser bem-sucedido, reconhecido financeiramente e constituir uma família. Na verdade o que todos desejam é ser felizes, como mostram as respostas à próxima questão.

Ao final da intervenção em Orientação Profissional referente à questão 11, sobre o que você deseja ser? No Grupo A os temas mais mencionados referem-se ao desejo de: ser bemsucedido e feliz na carreira $(n=18)$, ter estabilidade financeira $(n=7)$, seguir a profissão que desejam ( $(=3)$, ser respeitado $(n=2)$, construir uma família $(n=2)$, ter estabilidade psicológica $(n=1)$ e passar no vestibular $(n=1)$. Alguns registros exemplificam as respostas categorizadas acima: “eu desejo ter estabilidade financeira, muito sucesso na minha profissão, sem que ela seja estressante”; “espero ser uma ótima profissional, dedicada e que 
tenha prazer em exercer a profissão escolhida”; "não sei direito, quero ser feliz na profissão e estar com certa estabilidade financeira. Quero estudar sempre e aprender cada vez mais"; “desejo passar no vestibular, e fazer uma faculdade pública ou federal, e depois ter sucesso em minha carreira, com um bom salário”; “independente da minha profissão, espero obter sucesso na minha profissão, ter uma casa e poder criar uma família”.

No Grupo B da mesma forma que no início do grupo de Orientação Profissional os temas mais freqüentes no final do grupo é o desejo de: atuar como profissional na carreira escolhida ( $n=9)$; ser bem-sucedido $(n=3)$; ter uma família $(n=3)$; ser feliz $(n=1)$ e de ter estabilidade financeira $(n=1)$.

É interessante notar que os jovens almejam escolher uma profissão com garantia de estabilidade e perspectiva de futuro, em um mercado de trabalho no qual os caminhos são imprevisíveis. São observados valores tradicionais em tempos caóticos nas respostas dos participantes. As incertezas da atualidade geram necessariamente muitas angústias, pois o maior desejo continua a ser a busca por estabilidade pessoal, social e financeira. "A crise se aprofundou e exige criatividade. Só a criatividade nos permitirá uma existência digna em meio ao naufrágio de tantas esperanças que animavam ideologias já esquecidas” (WHITAKER, 1997, p.91). A autora aponta para além da criatividade, ou seja, o caminho da imaginação criadora como uma forma de construir projetos de futuro em um mundo de mudanças velozes.

A última questão (a de número 12) propõe a avaliação do questionário, quanto à qualidade, para examinar o que os adolescentes sabem sobre profissões e carreiras. O questionário foi bem avaliado de partida e, a nota ainda aumenta na segunda avaliação, com diferença significativa (78,6\% pré e 96,4\% pós), $p=0,04$. Os participantes elogiaram o questionário como uma forma de mostrar a eles o quanto sabiam (muito ou pouco) dando pistas para futuras buscas. A qualidade do questionário foi positiva no intuito de promover reflexões aos adolescentes em relação à importância da informação profissional. Assim sendo, o QIP cumpriu o objetivo investigativo desse estudo, ou seja, o de verificar se os adolescentes estavam buscando e tendo acesso às informações sobre profissões e carreiras. E, ainda foi muito útil como instrumento de intervenção. Entretanto, é prudente destacar que o QIP enquanto instrumento de investigação psicológica demanda ainda estudos que comprovem sua validade e fidedignidade.

Em síntese, os dados mostram que os adolescentes, deste estudo, não estão suficientemente informados sobre as profissões, embora avaliem que a informação profissional possa ajudá-los na tomada de decisão de carreira. Verificou-se, pelos comentários 
na questão 12, que a maioria pôde perceber mais claramente a necessidade de buscar mais informações acerca das profissões, mercado, formas de acesso à universidade, entre outros assuntos.

Os comentários nas questões e os registros das sessões grupais permitem observar que existe a idéia, em alguns jovens, de que todas as informações deveriam ser fornecidas a eles por outras pessoas, como: membros da família, professores e ou profissionais especializados, como orientadores educacionais e profissionais. A expectativa de que os “outros” é que devem fornecer a informação, denota um certo grau de dependência dos adultos sinalizando imaturidade, como será visto posteriormente ou ainda que muitos deles necessitam de procedimentos de intervenção mais diretivos, nesse caso presenciais.

As diferenças significativas, apontadas na comparação entre o início e o final da intervenção, apontam que o recurso mais utilizado pelos jovens para obter informação profissional, tanto antes como ao final da intervenção em Orientação Profissional, foi a internet. Os sites mais utilizados por esses adolescentes são: o Google e o Orkut. O local em que acessam internet é predominantemente a própria casa. Comunicar-se com colegas constitui o principal motivo para o acesso à internet. Ao final da intervenção em Orientação Profissional os adolescentes estavam buscando mais informações profissionais do que no início do mesmo.

Nas comparações realizadas entre o sexo feminino e o masculino, apenas algumas diferenças significativas foram detectadas. Dentre os recursos investigados foi observado que as moças no início da intervenção em Orientação Profissional buscam mais informações profissionais nos guias e nos livros que os rapazes. E dentre os possíveis objetivos com que as moças acessam os sites na internet, é superior ao dos rapazes o de realizar pesquisas escolares.

Ao final da intervenção as moças acessam mais que os rapazes a internet na casa de amigos. E o objetivo para as moças nesse momento é buscar informações sobre profissões. O único item em que os rapazes obtiveram vantagem em relação às moças ao final da intervenção em Orientação Profissional foi quanto à utilização da internet para jogar. Nesse momento do desenvolvimento da carreira e das exigências sociais demandadas, os rapazes parecem estar menos preparados ou ainda desinteressados, em comparação às moças, para empreenderem ações que os auxiliem em uma tomada de decisão profissional.

A média em que acessam internet é em torno de duas vezes semanais e de uma a duas horas diárias. Parece pouco, porém pode-se inferir que isto se deva ao fato de cursar as séries finais do Ensino Médio em escolas privadas, que por focalizarem aprovação no Vestibular, possuem uma extensa carga horária. As profissões mais citadas no início da intervenção em 
Orientação Profissional e ao final dele são da área de Humanidades. O que sugere um perfil motivacional dos participantes. Afirmam ter pouca informação sobre essas profissões, mas ao final da intervenção em Orientação Profissional demonstram mais confiança nas informações. Essas informações são prioritariamente obtidas em relacionamentos interpessoais. No início por meio de familiares e professores e, ao final do grupo, são ampliadas as fontes de consulta a colegas e a equipe do SOP.

A forma de acesso à universidade mais conhecida pelos adolescentes é o Vestibular, sendo outros processos seletivos desconhecidos pela maioria. Os jovens tendem a não verificar a relação candidato/ vaga do curso de interesse. O ENEM é conhecido entre os adolescentes, enquanto que o Sistema de Cotas é um dos mais desconhecidos e mais polêmicos. O mecanismo de acesso pouco conhecido é o ProUni, porém, é o mais aceito entre eles.

As informações sobre as oportunidades de trabalho no Brasil aumentaram ao final do grupo, os adolescentes concluíram ter um bom aproveitamento com as informações acessadas na internet, consideram, entretanto, serem necessárias mais informações profissionais. De um modo geral, pode-se perceber que os integrantes desse grupo adquiriram com a Orientação Profissional mais informações sobre as profissões de interesse como sobre o mercado em que está inserido, e principalmente podendo analisar o contexto social de uma maneira mais crítica e reflexiva.

Para Whitaker (1997, p.36) "O mais doloroso, porém, é que, mesmo para a grande maioria, preocupada com o mercado de trabalho, a desinformação é a regra. Os jovens não conhecem o conteúdo verdadeiro das profissões que almejam, e muitas vezes são empurrados para elas por forças externas que mal saberiam diagnosticar”. Embora, Whitaker tenha feito tal afirmação há uma década atrás, os dados deste estudo mostram que a despeito do aumento do acesso às tecnologias de informação e comunicação, ainda parte dos jovens que aspiram à carreira universitária está desinformada ou pouco informada.

O que sugere que com a Orientação Profissional obtiveram mais informações profissionais, em quantidade e qualidade, e que adicionalmente conseguiram refletir sobre o significado das informações. A Orientação Profissional e a informação profissional contribuíram satisfatoriamente dentro do desenvolvimento desses adolescentes e na aquisição do aumento do nível de informação profissional. Cumpre ressaltar que dentro dos objetivos específicos desta pesquisa, de avaliar o nível de informação de adolescentes para a tomada de decisão vocacional, no início e no fim do processo de Orientação Profissional, foi possível verificar contribuição para a sua evolução, em alguns itens, em curto prazo para intervenção 
de natureza psicológica. A avaliação das implicações a médio e longo prazo requer outros delineamentos metodológicos. Ao término da intervenção em Orientação Profissional os adolescentes apresentaram claramente um maior envolvimento com as informações profissionais, desenvolvendo condições propícias para a escolha da profissão e a possibilidade de desenvolver melhor a maturidade para a escolha da profissão.

\subsection{Maturidade Profissional}

A Maturidade para a escolha da carreira foi analisada conforme os resultados obtidos por meio da Escala de Maturidade para a Escolha Profissional (EMEP), em dois momentos do processo de Orientação Profissional (antes e depois) e em função do sexo.

Os resultados obtidos por meio da EMEP foram analisados em cada sub-escala: Determinação, Responsabilidade, Independência, Autoconhecimento, Conhecimento da Realidade Profissional e a Maturidade Total, e comparadas pré e pós-intervenção em Orientação Profissional, a fim de detectar se houve diferenças ou não e em que medida. Segundo Neiva (2002), a aplicação da escala no início da intervenção em Orientação Profissional permite ao orientador diagnosticar os aspectos mais ou menos desenvolvidos da maturidade do aluno e, poder assim planejar mais claramente o que deverá ser mais trabalhado no processo, ou seja, na sua evolução. A comparação, por sua vez, permite detectar as sub-dimensões que mais se desenvolveram e as que precisam ser trabalhadas na intervenção objetivando o desenvolvimento da maturidade. Permite, também, avaliar o resultado do procedimento de Orientação Profissional desenvolvido e foi neste sentido que foi utilizado no presente estudo. A Tabela 20 mostra os resultados obtidos por meio da EMEP, em cada sub-escala, nas situações pré e pós-intervenção. 
Tabela 20 - Resultados descritivos da maturidade para a escolha profissional, conforme subescalas da EMEP, em função da avaliação no início e ao final da intervenção.

\begin{tabular}{|c|c|c|c|c|c|}
\hline EMEP & Intervenção & Mediana & Média & $\begin{array}{l}\text { Desvio } \\
\text { padrão }\end{array}$ & Wilcoxon \\
\hline \multirow[t]{2}{*}{ Determinação } & Pré & 27,00 & 28,04 & 6,94 & \multirow[t]{2}{*}{$\mathrm{p}=0,001^{*}$} \\
\hline & Pós & 32,00 & 32,50 & 7,60 & \\
\hline \multirow[t]{2}{*}{ Responsabilidade } & Pré & 36,50 & 36,86 & 5,39 & \multirow[t]{2}{*}{$\mathrm{p}=0,37$} \\
\hline & Pós & 36,50 & 35,79 & 4,97 & \\
\hline \multirow[t]{2}{*}{ Independência } & Pré & 27,00 & 27,46 & 5,83 & \multirow[t]{2}{*}{$\mathrm{p}=0,08$} \\
\hline & Pós & 29,00 & 29,46 & 6,37 & \\
\hline \multirow[t]{2}{*}{ Autoconhecimento } & Pré & 24,00 & 23,50 & 4,32 & \multirow[t]{2}{*}{$\mathrm{p}=0,008^{*}$} \\
\hline & Pós & 25,00 & 25,64 & 5,09 & \\
\hline Conhecimento da & Pré & 27,50 & 27,11 & 6,01 & \multirow[t]{2}{*}{$\mathrm{p}=0,10$} \\
\hline Realidade & Pós & 30,00 & 29,82 & 5,07 & \\
\hline \multirow[t]{2}{*}{ Maturidade Total } & Pré & 142,00 & 143,75 & 15,97 & \multirow[t]{2}{*}{$\mathrm{p}=0,03^{*}$} \\
\hline & Pós & 151,50 & 153,21 & 18,05 & \\
\hline
\end{tabular}

(*) diferença significativa

Inicialmente tratar-se-á da primeira dimensão - Atitude - que Neiva (1999) divide em três sub-dimensões: (1) Determinação para a escolha profissional, (2) Responsabilidade e (3) Independência na escolha profissional. Na sub-dimensão "Determinação para a escolha profissional”, há diferença no resultado pós-intervenção apresentando valores significativamente superiores $(\mathrm{p}=0,001)$, o que significa que os participantes estão mais definidos e seguros com relação as suas escolhas. Esses dados corroboram os achados de Melo-Silva; Oliveira; Coelho (2002) em um estudo realizado no mesmo serviço, porém com uma amostra maior.

Em relação à sub-dimensão "Responsabilidade para a escolha profissional”, não há diferença significativa, como também não foi encontrada no estudo de Melo-Silva; Oliveira; Coelho (2002). Como pode ser observado na Tabela 20. Nessa sub-dimensão as mudanças não eram esperadas, um vez que a pontuação já era elevada na primeira aplicação, o que significa que o grupo já apresentava maturidade alta na situação pré-intervenção.

Apesar de não haver diferença significativa na sub-escala Responsabilidade, foi observado que os integrantes dos grupos se engajaram no processo de escolha profissional e empreenderam ações no sentido de efetuar sua escolha, o que foi observado pelo fato de a maioria dos participantes em ambos os grupos terem permanecido no processo grupal bastante 
motivado até sua finalização, participando ativamente das atividades propostas e efetuando as pesquisas de busca de informação e as tarefas para casa.

Quanto à “Independência”, não há diferença significativa, diferindo esse resultado dos achados de Melo-Silva; Oliveira; Coelho (2002). Essa sub-dimensão avalia o quanto a pessoa está se definindo sem influenciar-se pelas idéias de outras pessoas, como familiares, professores, amigos e meios de comunicação entre outros. Esse resultado indica que os participantes deste estudo ainda necessitam de tempo e/ ou ajuda para se tornarem mais independentes em suas escolhas. Na questão 5.4 do QIP no início do processo grupal, verificou-se a preferência dos adolescentes de buscar informações profissionais com familiares e com os professores. O que pode significar dependência, como foi verificado nesse resultado. Se por um lado, há indício de maiores dificuldades para a tomada de decisão, neste grupo de sujeitos, por outro, pode-se inferir que há vínculos positivos com as figuras significativas. No caso da dependência dos pais, trata-se de uma questão de difícil discernimento para o adolescente, em termos de vantagens e desvantagens desta situação. A dependência dos pais, nas atividades diárias, para os jovens de classe média e alta, pode chegar a ponto de ser confundida com a influência parental na escolha da carreira. E, nesse caso, embora muitos jovens e pais pensem que ela pode ser negativa, não necessariamente o é. Em termos de escolha da carreira é relevante tomar decisões autônomas e conscientes, reconhecendo e admitindo as limitações e as influências.

A segunda dimensão é a dos Conhecimentos e compreende duas sub-dimensões: Autoconhecimento e Conhecimento da realidade educativa e socioprofissional (Neiva, 1999). Na escala de “Autoconhecimento” há diferença significativa, os resultados mostram valores superiores na situação pós-intervenção. Esses dados corroboram os achados de Melo-Silva; Oliveira; Coelho (2002), pois após a intervenção em Orientação Profissional os adolescentes conhecem mais sobre si mesmos e suas características que são relevantes para a escolha profissional, como: características pessoais, habilidades, interesses, valores, dentre outros.

Como foi citado anteriormente, segundo Bohoslavsky (1991), existem algumas falhas na recepção da informação por parte do adolescente, que podem ser de ordem intrapessoal e interpessoal. O autoconhecimento seria, assim, uma das formas de sanar as possíveis distorções. Para Niles e Harris-Bowlsbey (2005), os jovens experienciam barreiras ao procurarem e usarem as informações, citando as barreiras: físicas, intelectuais, cognitivas ou ausência de identidade vocacional, que dificultam o processo de decisão profissional. Sendo necessário o auxílio do orientador profissional para que o jovem possa transformar a 
informação em significado próprio, priorizando o que é importante para ele e descartando o que não é relevante para sus decisão.

Na sub-escala “Conhecimento da realidade educativa e socioprofissional” não há diferença significativa, o que difere de outros estudos. Ainda que não se observe mudança estatisticamente significativa, a análise dos resultados obtidos por meio de outros instrumentos - o QIP e os registros dos grupos operativos - mostra que ao término da intervenção os participantes conheciam melhor as realidades sociais, escolares e profissionais (universo das profissões de interesse, cursos, instituições de ensino, mecanismos de ingresso, entre outras). Portanto, o resultado na EMEP a essa sub-dimensão não era esperado. Cumpre destacar que o QIP avalia se a pessoa está buscando informações sobre as carreiras e as profissões, sobretudo, as do interesse do jovem e, as formas tradicionais e alternativas de acesso à universidade. Por sua vez a EMEP aborda em seus itens relativos a essa sub-escala, mais o conhecimento sobre a maioria das profissões e o mercado de trabalho. Assim sendo, os resultados entre os dois instrumentos não podem ser comparados, uma vez que não há equivalência de conteúdo. São úteis, neste estudo, para reflexões sobre os diferentes componentes da informação. Pode-se inferir que após a intervenção, ainda que o grupo tenha tido acesso a mais informações, como evidenciaram os resultados do QIP, o nível de exigência aumentou, como mostram parte dos resultados do QIP. Assim, os resultados à subescala “Conhecimento da realidade educativa e socioprofissional”, na EMEP, revelam necessidade de mais informações. Afinal, quanto mais se tem informação mais dela se precisa. Inserir-se no universo das informações leva à necessidade de mais informações especializadas, em maior quantidade e qualidade. Como salienta Brown (2003), citada anteriormente, o jovem tem em diferentes momentos necessidade de informações compatíveis com sua etapa de desenvolvimento de carreira.

$\mathrm{Na}$ evolução da etapa exploração no desenvolvimento de carreira, o adolescente atravessa por diversas tarefas. Na medida em que os adolescentes adquirem mais informações sobre si mesmos e sobre o meio, correspondem às exigências do ambiente social no qual estão inseridos, e às suas próprias exigências, estariam mais maduros e com mais condições de resolverem qual a “melhor escolha” profissional, não apenas em curto prazo, mas também ao longo da vida e em articulação com os diferentes papéis - sobretudo o pessoal e o profissional - que serão desempenhados ao longo da vida.

Na Maturidade Total há diferença significativa na comparação entre os resultados pré e pós-intervenção. Assim, verifica-se que a maturidade como um todo alcançou patamares melhores, o que significa que os participantes tiveram avanços na aquisição de melhores 
condições em relação às atitudes (determinação) e nos conhecimentos (autoconhecimento). Nesses quesitos o processo de intervenção se mostrou bastante eficaz. Para Neiva (2002), muitos jovens concluem o processo de Orientação Profissional sem terem escolhido uma profissão, mas isso não significa que não evoluíram, tampouco que não amadureceram a sua escolha profissional. Normalmente, eles conseguem resolver as dúvidas restantes depois do encerramento do processo. Segundo Melo-Silva e Jacquemin (2001) a finalidade da Orientação Profissional é aprender a “escolher” e, esse processo não é acabado, ele se dá ao longo da vida conforme referencial da Teoria do Desenvolvimento, a intervenção, portanto, auxilia o orientando a dar mais alguns passos, tornando explícitas as condições nas quais ocorrem as decisões.

O resultado apresentado mostra que a intervenção grupal promoveu o desenvolvimento da maturidade profissional nos participantes de um modo geral, e mais especificamente nas sub-escalas Determinação e Autoconhecimento. Dentro dos objetivos específicos dessa pesquisa, de avaliar o nível de maturidade para a escolha profissional, no início e no fim do processo de Orientação Profissional, foi possível verificar que em algumas dimensões houve acréscimo significativo, contribuindo para a evolução do processo de escolha vocacional, principalmente em curto prazo. Como se trata de avaliação de processo e resultados, os resultados da EMEP apontam que as outras dimensões ainda requerem intervenção.

Os estudos que avaliam a intervenção no início e ao final não são unânimes em seus resultados. No trabalho desenvolvido por Carbonero e Tejedor (2204), os resultados apontaram para aumento da maturidade profissional. Já em outro estudo, o de Legun e Hoare (2004), não foram encontradas diferenças significativas após a intervenção. Uma das explicações encontradas por esses autores se deve à curta duração do processo de intervenção, que não propiciaria a visualização das modificações no momento da medição. Provavelmente essa interferência também se aplicada ao presente estudo que não apresentou um acréscimo em todas as sub-escalas.

Inclusive nas comparações realizadas entre as respostas em função do sexo, não houve diferença significativa em qualquer das sub-escalas. Ainda que Swanson e Foud (1999) apontem a relevância da variável gênero para os estudos sobre desenvolvimento de carreira, neste estudo não foram encontradas diferenças significativas, entre os sexos, na maioria dos itens do Questionário de Informação Profissional (QIP) e nenhuma diferença nas respostas obtidas pro meio da Escala de Maturidade para a Escolha Profissional, segundo a EMEP. Pode-se inferir que a ausência da diferença ocorreu em função da faixa etária ser relativa à 
adolescência, diferindo dos estudos com a população adulta nos quais a variável gênero ou sexo interfere, sobretudo em decorrência dos papéis de parentalidade.

Os estudos não são unânimes quanto aos resultados obtidos com relação à maturidade para a escolha profissional e a variável sexo, independente do instrumento utilizado. Nas pesquisas realizadas por Balbinotti (2003), o autor obteve resultados discrepantes ao compararem os sujeitos segundo o sexo e a maturidade profissional. O mesmo autor Balbinotti, et al (2004), em outro estudo, não observou diferença significativa entre moças e rapazes do Ensino Médio, como também, Lobato e Koller (2003) chegaram às mesmas conclusões em seus estudos. Já em Balbinotti; Tétreau (2006), os autores encontraram níveis de maturidade maiores nas moças, da mesma forma que o estudo de Neiva et al (2005). Esses autores concluem que as discrepâncias nos resultados dos estudos em relação ao sexo podem ocorrer devido a fatores regionais de diferenças sócio-culturais. Outros estudos são necessários para compreender melhor a influência da variável sexo na escolha da carreira em adolescentes.

A fim de melhor compreender e avaliar o processo de intervenção, objeto deste estudo, e também ampliar a compreensão das variáveis: informação profissional e maturidade para a escolha profissional, a seguir apresenta-se a análise da comunicação e da aprendizagem no Grupo Operativo.

\subsection{Comunicação e aprendizagem no processo grupal}

A seguir são descritas e analisadas as atividades desenvolvidas em cada grupo (A e B), bem como as reflexões dos participantes discutidas em Grupo Operativo. O processo grupal foi analisado a partir dos vetores: comunicação e aprendizagem, conforme Esquema Conceitual Referencial Operativo de Pichon-Rivière. No vetor comunicação se verifica como está a interação entre os integrantes, ou seja, as conversações que visam à realização da tarefa. Para o estabelecimento de uma boa comunicação é importante que os participantes possam ouvir e falar, que a comunicação seja de todos para todos, sem a formação de sub-grupos, sem conversas paralelas ou direcionadas exclusivamente para o coordenador. No vetor aprendizagem observa-se, a partir das trocas verbais feitas no grupo, como os integrantes aprenderam a lidar com as situações vivenciadas com criatividade, a fim de elaborar as ansiedades, dar um salto quantitativo em termos de aprendizagem relativa à finalidade do grupo e, assim, alcançar uma adaptação ativa à realidade. 


\subsubsection{O processo do Grupo A}

O primeiro encontro visou à apresentação e ao levantamento das expectativas. Uma atividade desenvolvida foi a técnica de apresentação individual em que cada integrante fez uma representação, um desenho livre, sobre alguma característica própria que permitisse sua apresentação ao grupo ou que pudesse contar um pouco sobre si mesmo. No início observouse certa dificuldade para a elaboração da tarefa, configurando-se uma situação de resistência diante do novo, mas gradativamente os integrantes foram se envolvendo com a atividade e com o grupo, quando então passaram a falar sobre si mesmos. As imagens representadas nos desenhos foram sobre atividades de lazer e hobby, como: os esportes (futebol, natação, vôlei, judô) depois o sair com os amigos (clube, tomar cerveja, falar no telefone) ir ao teatro, ao cinema, à praia. Também surgiram representações sobre o gosto pela música (tocar piano) e a vida familiar (meu cachorro, minha casa). Falaram sobre si, o que fazem melhor, nos esportes, na música e suas potencialidades, delineando-se, assim, a forma como cada um chega ao grupo em sua singularidade. A comunicação, inicialmente, era precária e feita apenas com o colega sentado ao lado, pouco contato visual ocorria.

A técnica de apresentação proposta cumpriu o objetivo de ser o disparador temático apresentação dos integrantes ao grupo - para iniciar o desenvolvimento dos vetores afiliação e pertença. Em princípio, os integrantes não se conhecem e têm pouca experiência na situação de dinâmica de grupo coordenado por psicólogos. Por essa razão a primeira atividade foi desenvolvida, visando estabelecer o vínculo entre os integrantes, destes com a coordenação e dos integrantes com a tarefa. Possibilidades se abriram para reflexões (comunicação) com o outro, a partir do compartilhamento das idéias surgidas no grupo e na vivência grupal alcançando a aprendizagem.

A segunda atividade, a Técnica do Cartaz: "Expectativas sobre o grupo de Orientação Profissional” (MÜLLER, 1988, SOARES-LUCCHIARI, 1993) começa com o grupo subdividido em 5 sub-grupos. Nesse momento foram trabalhadas as expectativas de cada um, os desejos de realizar a escolha “certa” que neste grupo significa gostar da profissão e ser bem remunerado financeiramente. Esses sentimentos são permeados pelo medo da indecisão, da falta de certezas não apenas pela profissão a escolher como também do novo mundo adulto que se apresenta diante desses jovens. O desejo de serem bem sucedidos, independentes, e de finalizarem a Orientação Profissional com respostas prontas e certezas permeia as reflexões em torno das expectativas relacionadas ao grupo de Orientação Profissional. Em um dos 
cartazes um integrante observa que existe o “passo a ser seguido”, esse comentário é compreendido como a necessidade de obter respostas a todas as angústias. A comunicação nesse momento começa a fluir de forma solta e prazerosa, os integrantes vão se conhecendo e aprendendo com o outro que não estão sozinhos em suas dúvidas e angústias.

As frases dos jovens na Técnica do Cartaz foram:

“A gente quer ser realizado, bem sucedido. Fazer escolhas, saber qual a profissão seguir, conhecer melhor as profissões. No cartaz colocamos: carros, mulheres, fazenda, neve, pois queremos viajar, dinheiro. Queremos profissão com dinheiro, para ter família, ajudar a família da gente. Eu tinha vontade de fazer música, sabe, mas a minha mãe diz que isso não dá dinheiro".

“Nós colocamos fotos de praia, profissão de Turismo. Uma dentista para representar a área de saúde. O ponto de interrogação porque está todo mundo indeciso. Esperamos que aqui esclareça, traga a conclusão, satisfação. Queremos carro, dinheiro, independência”.

“Desenhamos um túnel e a luz no fim do túnel. O que fazer? É a nossa pergunta. Espero que aqui esclareça porque a gente tá muito perdido. Estamos no meio do caminho. A gente tem idéias, não certezas”.

"Sorrisos de felicidade de poder estar aqui conseguindo decidir o que quer. Na foto dessa senhora dirigindo um carro, mostra um salto evolutivo, ética, confiança, um passo a ser seguido. Com persistência a gente consegue ter o poder de decisão. E essa moeda, que representa a estabilidade financeira, que todo mundo quer ter”.

“Muitas dúvidas no momento atual. Ter que desenvolver metas, acreditar que pode dar certo. Poder fazer o que quer, o que gosta, trabalhar com amor, investir no saber, ter mais oportunidades, encontrar as portas abertas”.

Após as apresentações, as discussões entre os participantes prosseguem. A conversação e a comunicação parecem mais densa e profunda, gradativamente alguns aspectos implícitos vão aparecendo. Aos poucos falam mais de seus medos, o primeiro a ser citado é o medo de ser barrado no Vestibular, de não ter a “oportunidade”, citam também as profissões desvalorizadas social e economicamente. As idéias se dividem em dois pólos contraditórios, gostar da profissão versus ter recompensa financeira, estudar versus divertir, nesse momento não há equilíbrio, complementaridade, só exclusão, uma ou outra opção. As dúvidas são muitas e a ansiedade se elevada.

O segundo encontro se inicia com a aplicação do QIP. A seguir são feitas as reflexões sobre o instrumento e em que ele mobilizou os participantes. Alguns avaliam que o questionário é repetitivo e outros se mostram angustiados por perceberem que não buscam 
informações profissionais, como mostram os resultados analisados anteriormente. Para vários deles o QIP provocou certo impacto, tornou explícita uma necessidade - de informações sobre as carreiras e as profissões. Nesse momento a coordenadora salienta a importância de efetuar as buscas através de sites e disponibiliza uma lista deles para pesquisas extra-grupo, as chamadas tarefas para casa. .

A “Técnica do Cine Adolescente” (SOARES-LUCCHIARI, 1993) constitui a segunda atividade do dia. Nela os participantes, em duplas, conversam sobre um filme e um personagem com o qual se identificam. A seguir um apresenta a escolha do outro ao grupo e as conversações têm início, focalizando autoconhecimento e escolhas. Analisando os relatos observa-se que a maioria acha difícil escolher apenas um personagem dentre tantas opções, mas as escolhas, aqui e agora, acontecem e claramente aparecem nas identificações com determinados personagens. As características pessoais salientadas foram: ser simpático, corajoso, ajudar os amigos/ os outros, lutar pelos objetivos/ por um ideal, ser persistente. Procuram algo que possa ser a escolha certa, é freqüente o “medo de fazer algo errado" sendo necessário uma ajuda extra-humana, como de "um anjo", de um "imortal” que possa solucionar as aflições. A necessidade da “ajuda de alguém”, “não quero ficar sozinha”, vem como um pedido claro à coordenação. Nesse momento, todas as ansiedades em relação a escolha são depositadas na coordenadora que, por sua vez, se mantém continente. Registra-se no grupo o momento de mudanças, de fim de um ciclo de estudo e início de outro, o Ensino Médio, depois o cursinho, a faculdade... Nos ciclos subseqüentes terão novos amigos, novas situações e lugares a serem conhecidos. O que se observa é o medo da assunção do papel adulto e suas implicações e, ao mesmo tempo a tentativa de elaboração do luto pela perda dos amigos da escola, da vida da infância, da família. Dialeticamente evidencia-se o par contraditório: VELHO versus NOVO, como exemplifica a fala a seguir.

“No cursinho vai ser solitário. Você perde contato com os amigos de anos! Sente falta! Eu converso com os meus amigos que estão na faculdade eles sentem falta. Quando acaba a escola, [Ensino Médio], já era. Não vai mais ser aquela amizade, cada um vai ter a sua vida”.

Nesse momento mesmo que todos estejam envolvidos pela vontade de solucionar rapidamente suas angústias, são propostas reflexões críticas para lidar com a situação de indecisão e ampliar as opções de escolhas profissionais. Em momentos como esses, de depositação intensa da ansiedade na figura da coordenadora do grupo há a tentativa dos adolescentes de encontrarem uma solução de forma rápida. E apesar de ser uma solução 
tentadora sabe-se que a decisão apressada será pouco eficaz em longo prazo quando se depararem com as demais opções oferecidas.

Percebem que nas escolhas existem influências que podem trazer grandes modificações em seu futuro, a solução é “continuar pesquisando” como aponta um integrante. Concluem o que a atividade sugerida teve como objetivo:

"Pra gente mesmo poder perceber com o que a gente se identifica”.

"Fez isso para ver que a gente se compara com quem luta pelos objetivos. Mas será que sempre fazemos isso?"

“Acho que para conhecermos um ao outro".

Nesse encontro a comunicação flui de um para todos, não ficando mais centrada na pessoa do coordenador. A discussão gera salto qualitativo na aprendizagem dos integrantes, principalmente sobre os ciclos evolutivos, observado nas falas sobre a necessidade de encarar a vida de uma forma dinâmica e cíclica e de elaborar os lutos (perdas) das etapas anteriores para poderem gradativamente iniciar um novo ciclo de vida. "Cada perda na nossa vida faz parte para você tomar novos rumos. Toda perda acaba sendo pra uma nova experiência”. Observam-se os vetores comunicação e aprendizagem no processo grupal.

A Técnica de Role-playing do papel profissional (MAHL; SOARES; OLIVEIRA NETO, 2005) é utilizada no terceiro encontro. Os integrantes já se conhecem melhor e demonstram estar mais à vontade, conversando entre si, fluindo bem a comunicação de todos para todos. A atividade é bem recebida e todos aderem à proposta.

Nessa atividade são disponibilizados guias e livros para complementarem as pesquisas sobre as profissões e carreiras que serão representadas pelos jovens. O coordenador evita responder as dúvidas a fim de ampliar a discussão entre eles e favorecer para que cada um possa elaborar as suas próprias reflexões. Nessa técnica o colega recebe a almofada e a profissão que terá que falar ao grupo. Assim tem a possibilidade de ampliar os seus conhecimentos sobre as diversas profissões existentes no mercado de trabalho.

As profissões escolhidas por eles foram: Psicologia, Economia, Carpintaria, Educação Física (Jogador de Futebol), Direito, Publicidade, Administração, Engenharia Eletrônica, Relações Internacionais, Agronomia, Medicina, Zootecnia, Jornalismo, Farmácia, Arquitetura, Biologia, Odontologia e Ciências Políticas. Em todas as profissões citadas pelos jovens foram destacadas as preocupações com os rendimentos financeiros, o que evidencia o valor que está nesse momento servindo de parâmetro para a escolha. As representações e verbalizações mostram as carreiras de forma idealizada, nelas não haveria problemas nem 
dificuldades. Quando alguns colegas mencionam as dificuldades inerentes a qualquer carreira, as respostas são direcionadas para soluções mágicas e para brincadeiras.

Dúvidas sobre o exercício de algumas profissões foram discutidas. Questionaram a diferença entre Psicologia e Psiquiatria, se jogador de futebol é profissão ou não e a diferença entre Administração e Economia. Ainda debateram temas como: a necessidade de dedicação para se alcançar o sucesso, a possibilidade de sair do Brasil para conseguir ser bem sucedido, a necessidade de aprender línguas diferentes, a vida acadêmica, a pesquisa científica no Brasil, a utilização de cobaias animais e as implicações éticas, a política e a corrupção. Ao final do encontro os integrantes concluíram que tinham poucas informações sobre as diferentes profissões e o mundo do trabalho. "Às vezes a gente fala que não gosta de uma profissão e nem conhece”.

Mobilizados pelo encontro os jovens percebem a necessidade de buscarem mais informações profissionais sobre as profissões de interesse, como mostraram os dados do QIP e da EMEP na situação pré-intervenção. Assim, foi proposto que cada um fizesse uma pesquisa - de livre escolha - sobre as profissões de interesse e apresentasse ao grupo com o objetivo de compartilhar as informações encontradas.

O quarto encontro inicia com a “Técnica do Bombom” (LEVENFUS, 2002) e depois a leitura do livreto “Conversa na Cozinha: escolha da carreira” (MELO-SILVA; PEREIRA, 2002). O grupo pareceu pouco à vontade na Técnica do Bombom, não tendo iniciativa de efetuar a escolha do bombom. Em alguns momentos parecem esperar passivamente pela autorização de alguém (colega ou da coordenação) para se posicionarem. Na segunda técnica esses sentimentos foram amplamente discutidos, aparecendo o vínculo de dependência paterna e a influência dos pais que até então fizeram todas as escolhas por eles e solucionaram a maioria de seus problemas.

“Os pais influenciam e confundem. Minha mãe dá uma opinião e se não gosto ela não concorda com o que falo. Ela quer que eu faça a profissão do meu pai e eu não quero”.

"Por mais que os pais falem é a sua vida”.

"Eu tenho muito medo, receio de desapontar".

Para muitos desses jovens é a primeira vez que vislumbram a possibilidade de fazer suas próprias escolhas. A independência pode parecer à primeira vista como algo prazeroso de almejar, no entanto percebem que o momento é de extrema responsabilidade, quando percebem não disponibilizar dos recursos internos necessários para a escolha profissional. Ao se depararem com as dificuldades como a instabilidade do mercado de trabalho ("O mercado de trabalho muda muito"), as profissões mais e menos valorizadas ( "Antigamente a profissão 
de professor tinha mais valor...”) e como essas alterações acontecem e modificam a vida profissional, ficam extremamente confusos e receosos de fazer as escolhas erradas.

Frente a essas dificuldades parecem se sentir inseguros e com poucas competências para efetuar a escolha mais acertada num mundo em turbulência ("O meu pai é advogado, mas uma época da vida dele, ele teve restaurante”). A tendência do grupo neste momento foi a de permanecer nos polos contraditórios (gostar da profissão versus ser bem remunerado), como aspectos excludentes, sem vislumbrar uma integração, o que gerou uma comunicação e uma aprendizagem superficial, não alcançando as causas implícitas das aflições. As discussões permaneceram acerca dos conteúdos explícitos e as resoluções formuladas pelos jovens parecem excludentes: a escolha da profissão que gosto ou ser bem remunerado ou contar com o apoio e aprovação dos pais.

No início do quinto encontro alguns integrantes relatam as pesquisas que desenvolveram sobre as informações das profissões escolhidas para a realização da tarefa, portanto, provisórias. Depois comentam sobre a tarefa proposta para casa sobre a "História do meu nome” e fazem posteriormente a leitura do texto “Detetive de si mesmo” (DIAS, 2002). O disparador temático se centra no autoconhecimento e aos poucos vão elaborando correlações com o conhecimento da realidade sócio-educacional (mercado de trabalho) que começam a aparecer como dimensões importantes a serem desenvolvidas por eles.

"Achei interessante que não tem que escolher pensando no mercado de trabalho de agora porque no futuro pode ser diferente”.

“As perguntas sobre autoconhecimento, o que gosta são importantes. Porque isso influencia, pode começar algo e não gosta por falta de autoconhecimento e de informação sobre o curso".

Começam a discutir sobre as outras dificuldades relacionadas à escolha, como: passar em uma boa faculdade, ter um bom emprego, trabalhar muito ou pouco e como isso é difícil para os familiares. Gradativamente os adolescentes vão percebendo a amplitude de suas questões, o que desperta a ansiedade pelo desconhecido. Assim, recorrem às brincadeiras, risos e piadas, para se acalmarem e aliviarem a tensão inerente a esses temas.

Embora tenham dado um importante passo no sentido de ampliarem seus questionamentos, podendo estar mais aptos a pensar nas profissões, a discussão em grupo não flui e eles a todo o momento parecem dispersos, tendo o coordenador que pedir que voltem à tarefa proposta. A angústia aumenta ao se depararem com as dificuldades inerentes às profissões, mercado de trabalho, estudos: “Tem que estudar bastante”, "É bem 
concorrido...”. A comunicação se torna entrecortada por silêncios e brincadeiras, conotando a ansiedade intensa. A aprendizagem ocorre permeada pelas angústias acerca do tema discutido:

“Dá para perceber, tá todo mundo viajando".

“Hoje eu não estou afim de falar não”.

Essa foi uma característica desse grupo por mais alguns encontros, recorrendo a brincadeiras, piadas, como uma forma de aplacar a ansiedade e as angústias frente a ter que fazer a escolha profissional. A comunicação e a integração através de brincadeiras entre os integrantes desse grupo foram intensas, o que em um primeiro momento foi interpretado como imaturidade, pouco envolvimento com a tarefa da escolha, como os dados do QIP e da EMEP mostraram. Entretanto, à medida que os medos foram sendo diluídos percebeu-se que puderam crescer em suas decisões com segurança e maior desenvoltura.

Cumpre destacar como dado relevante extra-grupo a participação mais expressiva dos familiares, na reunião de pais dos jovens atendidos nos setes grupos de Orientação Profissional do Serviço de Orientação Profissional. Os pais dos participantes do Grupo A compareceram em maior número se comparado aos demais grupos. No decorrer do atendimento grupal eles manifestaram preocupação com o transporte até o local dos encontros e a presença dos filhos nos grupos. Nesse grupo houve apenas três desistências do atendimento, sendo uma delas por motivo de doença. A questão é: isso ocorreu porque os pais são participativos ou os pais se envolveram no processo de Orientação Profissional porque seus filhos são imaturos? Até que ponto uma variável influencia mais que a outra pode ser um objeto de futuras investigações.

Um dos objetivos da Orientação Profissional é que o jovem possa definir a escolha da profissão de uma forma independente, optando pelo seu próprio projeto profissional, considerando conscientemente as influências dos familiares, amigos, professores e orientador profissional. As influências desde que trabalhadas de forma explícita podem contribuir para o desenvolvimento do sujeito que está inserido em um contexto social e familiar, construindo de modo ativo seu próprio projeto de vida.

No sexto e sétimo encontros o grupo foi subdividido para a aplicação do BBT-Br e da Técnica "Critérios para a escolha profissional”. E no oitavo encontro, com todos os integrantes do grupo reunidos, deu-se continuidade aos temas dos dois últimos encontros. Os integrantes apresentam suas pesquisa sobre a atividade Realidade Profissional (NEIVA, 2003a) e depois em duplas refletem sobre as estruturas de inclinação profissional, segundo o BBT-Br. Ao final do encontro relatam brevemente o que foi discutido em duplas. 
No décimo encontro alguns integrantes fazem as apresentações das profissões escolhidas e depois é proposta a leitura em sub-grupos de textos disponibilizados pela coordenação, sobre os temas: ENEM, PROUNI, FIES, Sistemas de Cotas e a Inclusão por Mérito. Em seguida os textos sobre esses assuntos foram discutidos em Grupo Operativo. Na discussão a maioria diz gostar do ENEM e achar ser um bom substituto para o Vestibular. O PROUNI é pouco discutido, não despertando muito interesse no assunto, o FIES parece não ajudar na angústia que vivenciam com o Vestibular, que é o centro da atenção e preocupação da maioria do grupo. O assunto que mobilizou mais foi o Sistema de Cotas Universitárias que, na discussão, gerou muitas polêmicas e controvérsias não sendo aceito com muita tranqüilidade.

“Na minha opinião, se aprovarem o Sistema de Cotas, está legalizando o racismo. É dizer que o cara é diferente mesmo",

"O Sistema de Cotas confirma a diferença”,

“Afirma que eles não têm capacidade, estão chamando eles de burro”.

As falas mostram que uma das medidas de ação afirmativa no Ensino Superior - as cotas universitárias - não é suficientemente compreendida, o que requer mais debates e esclarecimentos. Porém cumpre destacar que ações afirmativas existem exatamente para alterar situações polêmicas e têm caráter transitório (GUARNIERI, 2007).

No último encontro os participantes respondem à segunda aplicação do QIP e da EMEP. Alguns deles apresentam as profissões escolhidas. O disparador temático no início do encontro de encerramento foram as ansiedades frente ao mercado de trabalho e a necessidade de cada vez maior de estudos e de especializações:

“Tem muita gente, muita vaga, mas falta gente especializada, qualificada”.

“Mostra o quanto que o estudo é importante para ter emprego".

Os participantes buscam formas de se prepararem para as dificuldades que em breve terão que enfrentar. Nas técnicas aplicadas: “Um dia de trabalho daqui a 10 anos” e a técnica do Aeroporto (SOARES-LUCCHIARI, 1997), o futuro por eles imaginado é bastante idealizado, alguns conseguem se imaginar nas profissões enquanto que outros se vêem felizes, mas sem conseguir imaginar uma profissão para si. A seguir algumas falas exemplificam esse momento:

"Eu estava morando sozinho numa casa de praia e estava trabalhando com assessoria para empresas na bolsa de valores”.

“Eu estava casada, indo para a Disney com a minha filha. Tinha uma agência de Publicidade e Propaganda, e encontrei a T... (outra integrante) e ela era bióloga marinha”. 
“Eu estava casada, tinha um emprego que estava gostando, mas não consegui pensar em qual era".

“Eu estava indo para o Oriente Médio fazer uma reportagem”.

"Eu ia viajar a trabalho com meu namorado. Estava indo para um seminário de enfermagem".

“Eu ia fazer um concurso de publicidade, eu era publicitário”.

Assim, o grupo se encerra com alguns integrantes podendo escolher o curso em que imaginam prestar o Vestibular e outros ainda com medo de fazerem a sua escolha, mas já com possibilidades de refletirem para uma decisão posterior. A comunicação flui de maneira tranqüila, cada um ouvindo o outro e compartilhando esse momento de encerramento.

De um modo geral, parece claro que o grupo aprendeu bastante com o processo de Orientação Profissional, desenvolveu uma comunicação favorável para a troca de idéias e dos medos comuns a todos eles. A aprendizagem apresentou um salto qualitativo, sendo a tarefa facilitada pelo desenvolvimento do grupo. Cumpre destacar que os integrantes desse grupo tinham bom humor e participavam das atividades com muitas brincadeiras. Se por um lado, foi um grupo "leve”, tranqüilo, participativo, presente, por outro lado, foi um grupo muito dependente da coordenação.

O fato de o grupo ser formado por jovens imaturos também pode ter favorecido o predomínio de determinadas brincadeiras como forma de enfrentamento das situações de difícil resolução. Entretanto, deve-se considerar que mesmo sendo desejável um maior aprofundamento em alguns temas, é importante respeitar os limites psicológicos desses jovens nessa etapa de vida e as especificidades de cada grupo.

Na avaliação dos integrantes ao final do grupo, a maioria diz ter gostado do grupo, salientando que as discussões em grupo ajudaram a obter mais informações. Em seus comentários: "Eu gostei de tudo, acho que alcançou as minhas expectativas",

“Um grupo bem humorado que fez com que o clima da escolha não fosse de uma forma pressionada, da mesma forma que as atividades através das dinâmicas e discussões grupais também fossem encaradas com o melhor lado”,

"Eu avalio esse grupo como ótimo, as professoras [coordenadoras] são muitos dedicadas, as atividades me ajudaram a perceber em quais profissões eu me adequo”,

“A Orientação Profissional me fez sentir interessada, com vontade de pesquisar $e$ aprender sobre as profissões e me ajudou a como escolher quais princípios devo utilizar para escolher", 
”O grupo me ajudou como as opiniões discutidas e a partir destas, pude pensar e tomar decisões mais maduras”,

"Gostei muito do grupo porque me ajudou a decidir o que vou fazer daqui para frente”,

"Foi muito boa, me ensinou a pensar nos pontos positivos e negativos de cada escolha, me ensinou a perceber minhas possibilidades”,

"O grupo foi de extrema importância para esclarecimento dos meus conceitos a respeito das profissões. As atividades e a motivação dos colegas foi um fator significativo para o meu esclarecimento”.

Ao início da Orientação Profissional os integrantes apresentam estar com várias dúvidas e um grande leque de opções profissionais para serem refletidas. Ao final, dos 17 adolescentes que concluíram o grupo de Orientação Profissional: sete integrantes ficaram em dúvida entre duas profissões, oito escolheram uma profissão e dois integrantes permaneceram com muitas dúvidas em relação a suas opções. O que demonstra ser o grupo de Orientação Profissional um importante facilitador no desenvolvimento do projeto de carreira que não deverá se encerrar aqui, mas continuar a ser desenvolvido ao longo da vida.

\subsubsection{O processo do grupo B}

A atividade começou com a proposição de uma apresentação na qual cada integrante desenha em uma folha algo de que goste para a sua apresentação ao grupo. Os integrantes demonstraram empenho e interesse no desempenho da tarefa, alguns conversam entre si, mas com reserva, parecem estabelecer os primeiros contatos com desenvoltura.

Os temas apresentados por eles mostram a singularidade de cada um, mas também as características comuns entre eles. Em comum alguns falam dos esportes preferidos, dos times de futebol, dos amigos, da família, do namorado, da música, do computador, de acessar a internet, ler livros, vídeo-game (jogos), o lazer através dos barzinhos e do churrasco, das festas, da praia, da bicicleta, do skate e do contato com a natureza. Alguns já citam algumas preferências, como o gosto por teatro e a vontade de fazer Artes Cênicas, o gosto por números e pela Matemática, relacionando estes interesses com possíveis profissões. Outros exploram a sua personalidade, se descrevendo como:

“Tenho cara feia porque às vezes eu sou estressada, mal-humorada, mas às vezes também sou feliz e também sou confusa um pouco”. 
"Sou feliz, tímida e muito distraída...”

“Sou emotiva, romântica..."

Houve bastante envolvimento e dedicação na execução dessa primeira tarefa, o que parece demonstrar a motivação elevada deste grupo logo no início da Orientação Profissional. A comunicação flui de forma tranqüila e efetiva entre todos. Na próxima tarefa, a execução da Técnica do Cartaz (MÜLLER, 1988, SOARES-LUCCHIARI, 1993), a comunicação procede da mesma forma, produzindo aprendizagem e vinculação entre os integrantes.

Eles se dividem em quatro sub-grupos e voluntariamente optam por formarem dois grupos das moças e dois grupos dos rapazes. Os grupos falam sobre o desejo de ser reconhecido tanto profissionalmente como financeiramente, a busca do reconhecimento e a realização profissional como aspectos almejados e idealizados na futura escolha profissional, as expectativas em relação à orientação profissional. Os sentimentos freqüentes são de dúvida, insegurança, confusão, medo da concorrência no Vestibular como na profissão. Alguns citam as áreas de interesse, como: a de Exatas e a da Agropecuária. As frases que exemplificam são descritas a seguir.

“O sucesso depende de nossas escolhas, e é o que esperamos do teste vocacional”.

"Estamos de olho no futuro e tem muito blá blá, todo mundo falando na sua cabeça, chega, deixa eu pensar um pouco sozinho e enfrentar o vestibular”.

“O futuro é incerto, o mundo está diferente com novas coisas a todo tempo".

“O nosso mundo de escola, pai e mãe vai mudar, agora a gente vai tá sozinho, tem a faculdade depois a profissão. São novas experiências: amor, escolha certa da carreira, estudar e passar no Vestibular. São muitas as dúvidas em relação a profissão certa a seguir, tem a concorrência”.

"A família influencia muito, minha mãe quando falo que vou prestar fora de Ribeirão ela não gosta”.

Ao comentarem sobre os cartazes produzidos pelo grupo, os integrantes falam sobre diferenças de gênero, concluem que os rapazes são mais decididos, têm preferência por áreas determinadas e os objetivos claros, enquanto que as moças parecem estar mais em dúvida. Entretanto, concluem que com mais ou menos dúvida todos a têm, aliada a um forte desejo de realizar a sua escolha profissional. A síntese elaborada por eles ao final do encontro expressa um forte desejo de se libertarem de seus medos e angústias, inerentes a toda situação vivida de muitas dúvidas e incertezas, como mostram as frases a seguir.

"Liberdade dentro de nós para alcançar, queremos não liberdade aqui fora e sim liberdade dentro de nós”. 
“Libertar das angústias da escolha”.

"Liberdade para enfrentar o mundo pela frente".

"Abraçar o futuro, estar além com o horizonte..."

No segundo encontro logo ao chegarem começam a responder ao QIP, tarefa que executam de forma concentrada e em silêncio. A seguir é realizada a Técnica do Cine Adolescente (SOARES-LUCCHIARI, 1993). Na discussão inicial o disparador temático gira em torno da necessidade de ajudar o outro, que parece representar nesse momento inicial como um pedido de ajuda frente a todas as dificuldades. Eles demonstram dificuldade de relacionarem os personagens, alguns arriscam citando o curso de Música, a Medicina. Entretanto a maioria permanece em silêncio, a comunicação não flui, gerando uma maior ansiedade para o grupo como para a coordenação. Aos poucos algumas falas traduzem o medo de não estar informado, de se informar e mudar de idéia:

“Tinha certeza sobre o mercado de trabalho, agora não sei, porque quero Artes Cênicas, e aí?”.

“Eu não buscava informação só recebia quando vinha”.

“As poucas vezes em que busquei alguma informação eu acabei mudando de idéia”.

“E agora são muitos os meios de se informar, como a internet”.

Não ter informações ou resistir a elas confirma os resultados obtidos no QIP (falta de informações) e na EMEP (conhecimento da realidade abaixo da média) no início da intervenção. A busca por informação profissional por um momento torna-se o foco de seus problemas e angústias, questionam se ajuda ou não, qual a quantidade de informações e sua qualidade.

“Às vezes a informação fica só no superficial, acaba vendo só alguns pontos...”

"Acho que tem que restringir as informações, como ter que escolher dentro de tudo que você gosta, ter menos opção é mais fácil”.

“Com menos opção você tem mais chance de errar".

"Você vai pensando melhor, comecei a pesquisar várias profissões e cada uma que olhava alguma coisa não dava, não batia”.

Dessa fala em diante o silêncio volta intensamente no grupo, havendo dificuldade em elaborar todas as ansiedades que vão emergindo com as conversações. A situação vai se tornando cíclica, aparecendo novos silêncios. Nesse momento a ausência de comunicação conota a ansiedade elevada e a dificuldade de elaborar os acontecimentos e os sentimentos.

Esse momento só é quebrado quando alguns integrantes voltam a falar dos filmes, dos personagens. Algumas características vão aparecendo como prioridades, como: ser bem 
sucedida, ser honesto, lutar por uma causa. Aceitar o seu jeito de ser que muitas vezes pode ser atrapalhado, engraçado. Mas essas falas são intercaladas por guerra, violência, dificuldade de pensar. Algumas profissões são citadas, relacionam com as suas preferências, ideais; finalizam que precisam ser "batalhador", mas às vezes "o amigo morre”, fazendo referência a um filme, esse comentário é interpretado pela coordenação como o luto pela perda das várias outras possibilidades, excluídas ao se optar por uma carreira. Vão aos poucos percebendo que ao tomarem uma decisão, as inúmeras outras escolhas são deixadas para trás.

No início do terceiro encontro a Técnica do Barbante é realizada com o objetivo de fortalecer o vínculo entre eles e de facilitar a comunicação que no encontro anterior se apresentou tensa e entrecortada de vários silêncios. No encerramento da atividade um integrante conclui: "É um modo de se comunicar, falar as características ajuda a conhecer a gente, o que é igual ou diferente, assim que se forma um grupo”.

A partir dessa técnica o grupo pode desenvolver mais as questões implícitas que até então pareciam dificultar as discussões, valorizando as emoções que percebem estarem envolvidas na escolha profissional, no sentido de integrar as influências e os valores. O aspecto financeiro que inicialmente era entendido como o único valor a ser considerado na escolha profissional, dá espaço para outras questões. Uma delas é valorizar escolher algo de que gosta: “Escolher o que você gosta, fica mais fácil lutar por algo que você gosta”. E com determinação: “Tem que ter determinação. Quando eu estava no segundo colegial, terceiro colegial não dava bola pra profissão, aí caiu à ficha, tem que ir atrás, ver o que gosta, se gosta tem que ir atrás por que se não for ninguém vai por você”. Nesse momento observa-se o desenvolvimento da sub-dimensão determinação da EMEP.

Em seguida aparece o medo e o receio de não fazer a escolha certa e as conseqüências de uma escolha errada são discutidas. Numa espiral dialética os participantes oscilam em um contínuo da indeterminação à determinação. Nas situações vividas no grupo emergem as dificuldades, os obstáculos e, também as possibilidades. Quando a pessoa se conhece e passa a ter maior clareza sobre as dificuldades e as possibilidades, os obstáculos e os desejos, caminha-se em direção a construção de um projeto de vida próprio, como mostra a fala a seguir. "Um ponto legal da escolha não é ir apenas pelo que gosta, na verdade às vezes você não quer a profissão, quer ser o que determinada pessoa está sendo”.

Ficam atentos para os estereótipos de cada profissão, concluindo que os mesmos podem trazer influências positivas como negativas, nesse momento começam a trocar entre si idéias sobre a realidade do outro, acrescentando idéias à fala do outro integrante, o que pode 
promover o desenvolvimento do senso crítico sobre as carreiras. Assim, há um aprofundamento da aprendizagem e o desenvolvimento dos critérios que cada um acredita ser importante para a escolha profissional, como apontam alguns integrantes.

“Muitas vezes algumas pessoas falam para fazer Medicina, é o que ela quer e quer que você faça. Mas cada um tem a sua opinião. Quero fazer o que gosto, Biologia. Não simplesmente para ser famosa, mas porque gosto”.

“Tem profissões em todas as áreas, por isso tem que ver o que gosta pra se destacar e ser bom profissional... sucesso financeiro é muito raro, tem que escolher de acordo com o que gosta".

Os momentos de reflexão são intercalados com muito medo perante as dificuldades, entretanto já é possível a verbalização dos aspectos que estão trazendo incômodos e receios, como mostram as falas de alguns integrantes.

“Acordar todo dia pra algo que não gosta..."

"Difícil decidir o que quer com 17 anos".

“É muita responsabilidade”.

"É a primeira vez que podemos escolher o que fazer da vida, na escola tem que fazer todas as matérias agora tem que escolher algo que verdadeiramente gosta”.

“A questão é não ser muito influenciável com as pessoas que conversam com a gente..."

A partir daí citam as influências e as insatisfações dos pais perante a vida e a profissão, os sentimentos que permeiam são de impotência, medo de não serem aptos para a escolha certa.

“Minha mãe abre o portão já reclamando de ir pra escola, é todo dia sempre assim, já até sei o que vai falar",

"Antes os pais definiam a profissão do filho, hoje não é tão explícito, mas não deixa de ter influência, uma fala, uma cara feia...isso mexe muito!”

Citam a influência dos professores e tentam verificar se todos os tipos de influência são ruins:

“As vezes ouvir opiniões é legal até do meu professor de química...”

Mas a escolha traz um ônus de responsabilidade e sempre a possibilidade de ter feito a escolha errada e como podem se defender desses medos que às vezes impedem a reflexão.

“Nada do que decidir é pra sempre, não gostei parto para outra”.

“Mas quando perceber tem que sair rápido, pois gasta muito tempo da vida”.

“Depois se forma e não é feliz”. 
Diante da angústia um integrante cita os testes profissionais como uma solução mágica a todas as dificuldades e possibilidades de errar ("Por isso existem os testes em Orientação Profissionsal”), a sorte aparece também ( “Quando faz o que não gosta tem que contar com a sorte”), entretanto, o grupo opta e consegue prosseguir na discussão tentando citar exemplos de quem não acertou na profissão, como os familiares, as experiências que vivenciaram, outras que ouviram através dos pais e como agiram a partir da descoberta de não gostarem da profissão, as experiências bem e mal sucedidas, a pressão de fazer a escolha certa, a dúvida de que essa escolha permanecerá pela vida toda. Eles procuram ansiosamente por uma forma de não errar na escolha profissional.

A conversação flui intensamente, revelando os medos mais latentes e implícitos. Até que algumas soluções são citadas como a de contar com o apoio da família, buscar uma vocação e um dom dentro de cada um.

“É importante o apoio da família...”

“Importante é gostar e ter o dom. Porque que adianta gostar de Arquitetura se não tem o dom pra desenhar, que nem eu, mas se gosta muito pode batalhar. A Educação Física eu já sei fazer é mais viável pra eu crescer, meu amigo vai ser arquiteto e tem o dom pra desenhar...”

Ao procurarem por referências dos outros, de uma fórmula pronta, pedem à equipe de coordenação que contem as suas experiências pessoais sobre o processo de escolha profissional. Tal pedido é atendido e a coordenação procura deixar claro que é importante toda essa troca de informações, entretanto, cada um terá que buscar o seu próprio percurso no desenvolvimento de carreira. A mensagem é atentamente percebida e a conclusão vem na fala de um integrante que encerra o encontro do dia. "Cada vez mais na profissão é você com você mesmo, eu achava que as coisas iam acontecer comigo automaticamente, a profissão você tem que ser alguma coisa é integrar o tempo todo". Essa fala evidencia desenvolvimento das atitudes: determinação, responsabilidade e independência.

No quarto encontro a discussão se centra nas expectativas dos pais e de como reagem a esses sentimentos, através das atividades “A história do meu nome”, a ARGEVOC (MÜLLER, 1988) ou Genoprofissiograma (SOARES-LUCCHIARI, 1997). Alguns trazem exemplos de famílias que "deram certo" profissionalmente, outros citam experiências que “não deram certo” e levaram as pessoas a optarem por outra atividade profissional. Tais exemplos, de "erros naescolha” gradativamente elevam o estado de tensão e o silêncio se instala, dificultando a comunicação. As falas são curtas. “Não puxei nada para a família do 
meu pai, acho que sou mais do jeito da minha mãe, que é mais humanas..." "Minha mãe fez três faculdades, acho que tenho o direito de ter dúvida...”

Com o silêncio predominando, a coordenação opta por propor a escrita individual de uma carta, com o título: “Carta aos pais” (SILVA; VENTURINI; MELO-SILVA, 2005). Aderem à atividade prontamente e com concentração, ao terminarem fica evidente o alívio e a satisfação de poderem colocar todas as angústias do implícito para o explícito. A comunicação se estabelece de forma fluida, quando então passam a trocar idéias sobre a pressão em excesso que sentem e, também sobre o oposto, pois alguns sentem é a falta de atenção às suas dúvidas por parte dos pais. Concluem que podem conversar livremente sobre os pais, os vínculos, como mostram as frases a seguir.

“Eu nunca achei que amava tanto os meus pais”.

“Foi um desabafo, é bem mais fácil escrever do que falar”.

"Foi um aviso do que já sabia, eu converso com eles, mas foi diferente, acho que descobri o que gosto!”.

“O meu foi mais agradecimento, se não fosse eles eu não tinha chegado até aqui".

"Meu pai e minha mãe sempre falaram pra eu fazer o que quiser, mas as vezes acho que ia ser bom escutá-los”.

No quinto encontro, a partir da Técnica das frases para completar (BOHOSLAVSKY, 1991), adaptada por (SOARES-LUCCHIARI, 1997), eles respondem as frases individualmente e depois em duplas discutem sobre as informações que vêm adquirindo. Ao final do encontro em um breve momento, alguns sentem falta de mais informações e conseguem trocar entre si através de uma comunicação que flui para todos os integrantes. Essa atividade pôde ser ampliada no sexto encontro por meio da realização da atividade Critérios para a escolha profissional (NEIVA, 2003a), por meio de mais informações profissionais, quando tentam integrar os hobbies que são parte de suas habilidades e gostos, como apontam as falas a seguir.

“É interessante, cada vez tenho mais certeza daquilo que eu quero”.

“Esse negócio do hobby é legal, eu nunca tinha pensado que posso talvez também poder trabalhar com coisas que gosto de fazer...”

As dificuldades perante o assunto aparecem de forma latente e com receio, só no final do grupo um integrante verbaliza que já pensou em parar de participar do grupo por achar que não irá agüentar suas dúvidas, entretanto, outro rebate ser uma possibilidade no grupo de falar e poder pôr para fora o que sentem e pensam. 
"Aqui falamos de ambiente de trabalho e de certas coisas que a gente não para pra pensar. Acho que quero Economia, mas é muito frágil a escolha. Já pensei em parar a Orientação Profissional, mas agora vejo que é melhor poder estar aqui”.

"O que a gente conversa aqui só traz melhora independente da profissão, engloba outros aspectos”.

O Teste BBT foi realizado no sétimo encontro em todo o grupo, com aplicação coletiva, porém cada participante utilizou um conjunto de fotos individualmente. No encontro seguinte a discussão abarca temas da informação profissional, acerca das profissões que apresentam maior interesse até o momento. Os temas abordados foram referentes às dúvidas e suas dificuldades nas diferentes áreas de interesse: mercado de trabalho, prazer na atividade (os hobbys), retorno financeiro, dificuldade de passar no Vestibular, concorrência (candidato/vaga). O sentimento de confusão aparece para alguns, marcado pelo medo de não se encaixarem no mercado de trabalho.

“A nossa vontade conta, mas tem o que o mundo impõe, eu queria fazer Gastronomia primeiro [...] mas tem a estrutura de vida hoje em dia que é muito importante. Tem o mercado de trabalho, vai ter a cobrança...mas você tem que ser cada vez mais você mesmo”.

“Tem a competição, nem tudo é tão bonito”.

“O problema é que quando quer algo só pensa no lado bom, mas também tem o lado ruim. E se não conseguir entrar no mercado".

“Tem que ter persistência, a dedicação vale também”.

“Tem que ter persistência, senão não vai longe, se você desiste não consegue nada”.

“Os obstáculos vamos ter sempre, mas se planejar já prevendo algumas certezas, como alguma coisa que te agrada, fica mais fácil”.

Mesmo que os integrantes estejam confusos sobre alguns temas, a comunicação flui entre eles, podendo desenvolver e ampliar o aprendizado que têm acerca das profissões e de todas as informações necessárias para o desenvolvimento de carreira. Nesse encontro foram encerrados os temas sobre informação profissional, partindo em seguida para as entrevistas e encerramento do grupo. Nas entrevistas, os participantes foram unânimes em demonstrar que estavam preparados para o final da Orientação Profissional, estando alguns mais prontos para a escolha profissional do que outros. A maioria já havia realizado a sua escolha profissional (oito integrantes) e os demais (três integrantes) que permaneciam em dúvida acreditavam que poderiam prosseguir sozinhos, e que apenas precisavam de um pouco mais de tempo para se decidirem. 
No início do processo grupal verificou-se que o Grupo B chegou para a Orientação Profissional com algumas profissões provisoriamente definidas. Ao término do grupo, em sua maioria os integrantes do grupo apresentavam o desejo de ser os profissionais escolhidos denotando maior segurança e convicção em assumir a sua escolha profissional, o que demonstra estarem os integrantes do Grupo B ao término da Orientação Profissional mais seguros e podendo optar por buscas mais autônomas.

Os adolescentes refletiram sobre vários temas no décimo encontro do grupo de Orientação Profissional, discutiram acerca de um futuro quando fosse possível um bom mercado de trabalho, ter oportunidades de emprego, estabilidade financeira, confiança pessoal no desempenho profissional, ser reconhecido como um bom profissional e feliz. Observou-se que a discussão estava madura, pois focalizava importantes questões a serem consideradas na decisão. Além disso, a comunicação era fluida e distribuída, todos podiam ouvir, falar e refletir sobre importantes questionamentos, propiciando saltos qualitativos na aprendizagem da escolha.

“As oportunidades são poucas, há muitas pessoas desempregadas, que não são qualificadas para um mercado tão exigente”.

“Agora com toda a informação que tenho fica mais fácil de decidir”.

“Tem que se preparar para enfrentar um mercado de trabalho disputado”.

"É importante conseguir estabilidade financeira, ter uma família..."

O grupo avaliou ter tido bons proveitos com as atividades e conseqüentemente desenvolvido as suas habilidades para lidar melhor com o momento atual. Alguns de seus comentários foram são descritos a seguir.

“Adorei o grupo, é muito legal essa troca de idéias entre os colegas e a coordenação, isso me ajudou muito, pois deu pra ver que não era só eu que tinha dificuldades na escolha profissional”.

"Foi muito importante pra mim o grupo, consegui ser aceito por todos, tive as minhas idéias ouvidas, e ouvi a dos outros”.

"O grupo me ajudou a decidir minha profissão, conhecer os meus medos e a enfrentar essa nova fase da minha vida”.

"Eu cheguei no grupo com muitas dúvidas e estou saindo com poucas. Ainda não fiz a minha escolha, mas sei que estou perto”.

"O grupo era descontraído e ao mesmo tempo sério. As atividades me ajudaram a me descobrir e os colegas apóiam para a futura profissão”. 
Esse grupo termina o processo de Orientação Profissional mais certo das dificuldades que terá que enfrentar tanto no aspecto pessoal, referente ao autoconhecimento, como no aspecto referente ao mercado de trabalho e todas as particularidades de cada carreira. Obtiveram um salto qualitativo referente a aprender a se comunicar melhor em todos os aspectos, aprendendo a partilhar as experiências comuns e as diferenças entre os integrantes. A análise do Grupo Operativo permitiu verificar que os dados qualitativos foram complementares aos achados da análise quantitativa. 


\section{CONSIDERAÇÕES FINAIS}

A questão inicial que suscitou este estudo foi relativa ao papel da informação profissional no desenvolvimento da maturidade em jovens atendidos em um grupo de Orientação Profissional presencial. Este estudo foi realizado considerando o cenário contemporâneo, de avanços das tecnologias de informação e comunicação, que cada vez mais vem trazendo velozes modificações em diferentes áreas do conhecimento. Assim, o processo do grupo total foi avaliado em função da informação profissional, da maturidade para a escolha profissional e da comunicação e da aprendizagem no grupo operativo. A hipótese era de que os adolescentes, que precisam de informação sobre as várias profissões existentes e que utilizam a internet como instrumento de comunicação e aprendizagem, não estavam utilizando, de maneira proveitosa, as informações sobre as profissões e as carreiras. Os achados confirmaram essa hipótese.

Os resultados obtidos por meio do QIP evidenciaram que os jovens, no início do processo de Orientação Profissional, não estavam buscando informações profissionais úteis ao processo de tomada de decisão de carreira em quantidade e qualidade. Esses achados contribuem para a discussão sobre os procedimentos de orientação profissional destinados aos jovens, que devem cada vez mais estimular e monitorar o uso dos recursos da tecnologia da informação e comunicação de maneira proveitosa.

É importante salientar que os jovens tendem a utilizar preferencialmente a internet como uma forma de recreação e comunicação entre os amigos. Como os achados deste estudo evidenciam o uso inadequado e/ ou insuficiente da internet na prática diária para o acesso a informações sobre profissões e carreiras (universitárias, tecnológicas e técnicas), cabe aos orientadores profissionais a definição de estratégias mais eficazes que possam reverter esse quadro com vistas a tornar a busca via internet mais útil nos processos de decisão.

A análise comparativa entre os sexos mostrou a tendência dos rapazes preferirem a internet para jogos enquanto que as moças a utilizam para as pesquisas escolares e para a busca de informação profissional. Ao final do grupo ambos os sexos estão se informando mais acerca das profissões. Quanto à Maturidade para a escolha profissional, em função do sexo, não foi encontrada nenhuma diferença significativa neste estudo, corroborando alguns estudos, como apontado anteriormente e divergindo dos achados de outros, o que evidencia a necessidade de mais estudos. 
Na busca de informação profissional os adolescentes mostram preferência no início da intervenção em Orientação Profissional em procurar informação profissional com os familiares e com os professores, ao final preferem ainda os familiares, mas incluem os colegas e os Serviços de Orientação Profissional, o que demonstra a utilidade e a necessidade de se desenvolverem diferentes tipos de serviços voltados para as diferentes necessidades dos adolescentes.

Neste campo existe muito a ser conquistado pelos profissionais de Orientação Profissional no Brasil, objetivando o auxílio efetivo à juventude, como a criação de centros especializados, de iniciativa tanto pública quanto privada, onde os adolescentes possam buscar informações profissionais com a utilização de recursos variados como vídeos, jornais, livros e os vários programas de computadores e, ter orientação no planejamento da carreira. É necessária a oferta de diversos programas para diferentes demandas. Segundo Niles e HarrisBowlsbey (2005), como o número de carreiras e ocupações é muito grande, torna-se impossível para muitos adolescentes aprender individualmente como elaborar um planejamento de carreira de uma forma organizada. Para tanto, é fundamental a introdução do papel do orientador profissional, no contato com esse jovem, como mediador entre as referências afetivas de familiares, professores e colegas que o influenciam no planejamento de carreira, com informações precisas sobre as profissões e mercado de trabalho.

Espera-se que os resultados obtidos por meio deste estudo que possam contribuir para destacar ainda mais a importância da informação profissional, também salientada na literatura internacional, por Fouad (1994), cujo estudo de revisão, já fazia recomendações para pesquisas futuras sobre esse tema, quando a internet comercial estava começando no Brasil. Além disso, cumpre destacar a crescente utilização das novas tecnologias de informação e comunicação, que vêm trazendo inúmeras modificações tanto na vida dos adolescentes, como na do orientador e no próprio campo da Orientação Profissional. Cada vez mais é relevante a informação profissional no processo de Orientação Profissional, uma vez que “[...] seu objetivo básico deve ser o de fornecer informações fidedignas sobre profissões de modo a estimular a reflexão sobre o seu exercício numa sociedade como a nossa” (FERRETTI, 1988, p.77). Segundo o autor os três aspectos a serem destacados referem-se à fidedignidade da informação, ao caráter de estimulação reflexiva e à característica histórica de que a informação deve se revestir. Se a qualidade da informação profissional já era tida como importante no século passado, antes do advento da internet comercial, na contemporaneidade é mais ainda. 
Para tanto cada vez mais se torna imprescindível ficar atento, também, à formação e à capacitação do orientador profissional, principalmente no mundo atual repleto de modificações e de novas tecnologias que impõem não simplesmente uma adequação, mas uma total revisão de valores e possibilidades. Ou ainda como salienta Watts (2002), as novas tecnologias em Orientação Profissional têm o potencial de “um agente de mudança”, trazendo grandes modificações nos mais diversos setores da sociedade.

Os achados deste estudo mostraram que os integrantes do grupo passaram a ter mais informações disponíveis por terem efetuado mais buscas e mais direcionadas aos seus objetivos. Assim, eles conseguiram tirar um maior proveito. Estes dados vão ao encontro dos resultados obtidos por Niles e Harris-Bowlsbey (2005), pois para eles, o mais difícil e essencial papel do orientador profissional é ajudar o estudante a elaborar, entender as informações necessárias e utilizar a informação que deve ser esclarecida e aprofundada e desprezar as que devem ser removidas. Nesta questão os integrantes do grupo puderam efetuar essa diferenciação das várias informações sobre as profissões e utilizar as que realmente são necessárias para a escolha da profissão. Processar a informação que recebem, e utilizá-las de forma ativa, foi um resultado positivo para a avaliação da intervenção em Orientação Profissional.

Na intervenção, objeto de análise deste estudo, a atitude dos jovens, no início do processo, era a de esperar que as informações profissionais fossem fornecidas passivamente de alguma fonte: orientadores profissionais, professores, palestras com profissionais, uma vez que pareciam pouco motivados para buscar de forma autônoma as informações necessárias. O fato de estarem buscando mais informações profissionais pela internet, no final, pode mostrar que o processo de Orientação Profissional promoveu no jovem autonomia para buscar suas informações por seus próprios caminhos e assim progredir no desenvolvimento da autonomia, da independência e da maturidade total.

Uma das principais vantagens da internet é o fato de ter uma grande quantidade de informações, com opções dentro de cada site onde cada um pode escolher os seus caminhos, preferências e assim podem gradativamente a aprender a realizar as pequenas e grandes escolhas. A situação de busca, além de resultar em conhecimento, é uma situação de treino em tomada de decisões.

Entretanto, fica evidente que o adolescente necessita de uma prontidão ou de maturidade profissional para efetuar as buscas de informação profissional. É preciso intervenção eficaz para a ativação do desenvolvimento vocacional. Não basta ter a oferta de informação profissional na internet se o adolescente não está pronto para usufruir dela. Existe 
um percurso a ser realizado por alguns adolescentes para que as informações possam facilitar ou até promover o aproveitamento do conteúdo disponível na internet. E, é nesse sentido que intervenções presenciais em Orientação Profissional, como a que é objeto deste estudo, devem continuar a ser desenvolvidas e avaliadas.

A internet foi cercada desde a sua criação e ampliação crescente de uma grande expectativa sobre os benefícios que poderiam ser gerados a partir das suas potencialidades. Entretanto, cada vez mais as pesquisas demonstram que não basta disponibilizar a internet, mas que é necessário promover o desenvolvimento do conhecimento do usuário de qualquer faixa etária. No caso do jovem, não basta ter acesso a essa ferramenta se ele não sabe como utilizá-la em seu proveito (TARGINO, 1997). .

Além disso, a oferta de informação e orientação profissional online não diminui a necessidade da intervenção face-a-face como se supunha (GUICHARD; HUTEAU, 2001). Pessoas diferentes, e em momentos diferentes, necessitam de estratégias e níveis diversificados de intervenção, inclusive se o adolescente está ou não maduro para ter um aproveitamento das informações disponíveis. Este estudo mostrou que jovens com acesso à internet e que possuem habilidades para navegar na rede ainda precisam do orientador estimulando-o no uso proveitoso dessa ferramenta para fins de tomada de decisão de carreira.

Além de contribuir para a produção do conhecimento sobre problemáticas como informação e maturidade profissional, este estudo contribui, também, com o saber relativo à avaliação de processos e resultados de um procedimento de intervenção em grupo operativo, como apontado anteriormente. Em relação ao desenvolvimento da maturidade para a escolha profissional os resultados mais evidentes foram nas sub-escalas Determinação e Autoconhecimento e na Maturidade Total.

Os resultados obtidos quantitativamente e qualitativamente evidenciaram o desenvolvimento da Informação Profissional e da Maturidade Total para a escolha profissional. Contudo os dados qualitativos do Grupo Operativo proporcionaram um acréscimo aos dados quantitativos e diferenciaram algumas características do Grupo A e do Grupo B, já definidas na composição dos grupos de intervenção.

O Grupo A apresentou um bom crescimento, mas com reflexões menos profundas implicitamente, entretanto, neste grupo houve uma grande vinculação entre os integrantes, o que favoreceu a troca entre eles e a comunicação. Enquanto que no Grupo B, as reflexões foram mais profundas nas questões sobre a escolha e o autoconhecimento, entretanto eles apresentaram em vários momentos dificuldades na vinculação. Em ambos os grupos, contudo, a comunicação se estabeleceu entre eles, no sentido de expor suas idéias, ouvir e aprender 
com o outro no estabelecimento dessa troca, aprendendo, sobretudo a pensar sobre si e a respeitar o outro.

Um fato importante que promove reflexão é de que o grupo heterogêneo, inclusive no que concerne a maturidade, seja mais interessante na superação das dificuldades dos vários temas propostos pela Orientação Profissional. Esse dado foi observado principalmente no Grupo A que em alguns momentos teve maior vinculação e, também, maior dificuldade de superar alguns temas que provocavam ansiedade e angústias. Por este fato ele poderia ter um tempo maior de duração. E no Grupo B, por serem todos com maturidade para a escolha profissional na média, apresentaram um comportamento mais independente, terminando o grupo com um encontro a menos, sugerindo que nesse tipo de população, com este perfil e demanda, é possível atendimento mais breve.

Com isso pode-se pensar na Orientação Profissional como um processo mais amplo que prepara o jovem não só para a escolha de carreira, mas para o desenvolvimento de sua carreira ao longo da vida. Destaca-se a importância de um novo paradigma da escolha profissional, que deverá ir além de uma simples escolha de profissão, para a formação de um profissional dinâmico, em constante desenvolvimento em relação a si e ao mundo em que está inserido.

Um aspecto importante e necessário na utilização da internet na Orientação Profissional é quanto aos cuidados éticos. É necessário o desenvolvimento de mais estudos que possam colaborar para a melhoria e a segurança dos serviços disponíveis, como alertam as pesquisas na área. Alguns temas são importantes como a qualidade das informações, credibilidade e manutenção do sigilo dos dados pessoais do usuário.

Finalizando, foram observados progressos quanto à aquisição de mais informações profissionais, visando o desenvolvimento da maturidade para a escolha da carreira ao final do processo e tais evoluções permitem concluir que houve a eficácia da intervenção em grupo presencial, conforme proposto neste estudo. Com o procedimento de intervenção os participantes passaram a utilizar mais a internet como um instrumento para a busca de informações profissionais, apresentando conseqüentemente mais conhecimentos sobre o universo educacional e profissional. Os resultados do QIP e a análise qualitativa permitem tal conclusão ainda que os resultados da EMEP, no item conhecimentos sobre a realidade educativa e socioprofissional, não tenham sido significativos. Cumpre destacar a importância de se analisar um objeto de estudo por meio de diferentes instrumentos. Por outro lado, o QIP não foi construído com equivalência de conteúdo à EMEP, o que pode ter produzido tal resultado. Outro ponto a ser destacado é o pequeno número da amostra $(n=28)$ para estudos 
quantitativos. Assim sendo, uma das limitações neste estudo refere-se ao número de sujeitos. Estudos com número maior são necessários para generalizações. Outras investigações são necessárias com sujeitos que não procuram a Orientação Profissional. Eles estariam fazendo um uso mais proveitoso das informações? Como é a maturidade para a escolha da carreira e pessoas que não buscam Orientação Profissional? Estudos de validade do QIP também se fazem necessários. Investigações longitudinais também são relevantes.

Com esse estudo se pretende dar mais alguns passos na produção do conhecimento da área de Orientação Profissional no Brasil, em sintonia com os trabalhos que vêm sendo desenvolvidos no âmbito internacional. E assim capacitar cada vez mais a prática profissional na área, ou seja, nas palavras de Karl, "Poder capturar o presente, as inovações tecnológicas, sem negar o passado, utilizar todos os aspectos do passado para desenvolver idéias da atualidade” (KARL, 1985, p. 35).

A informação profissional como eixo da intervenção e/ ou como dimensão psicológica da maturidade para a escolha da carreira, em seus diferentes mecanismos de acesso, impresso ou por internet, em processos presenciais e virtuais deve continuar sendo foco de análise e contribuir para a implantação de programas de orientação vocacional, compreender a exploração vocacional, estimular a elaboração de políticas públicas e a avaliação da oferta de serviços, nesse domínio. Definir trajetórias de carreira é sempre necessidade de jovens e adultos o que torna esse campo promissor para investimentos na pesquisa e na prática, sobretudo as de natureza avaliadora. 


\section{REFERÊNCIAS}

A UNIVERSIDADE E AS PROFISSÕES, Pró-Reitoria de Cultura e Extensão Universitária da Universidade de São Paulo, São Paulo: Imprensa Oficial do Estado, 2001.

ACHTNICH, M. Teste de Fotos de Profissões (BBT): método projetivo para a clarificação da inclinação profissional. São Paulo: CETEPP, 1991.

ALMEIDA, F.; MELO-SILVA. L.L.Grupo de pais: relato de experiência em grupo operativo. In: I Congresso Latino-americano de Orientação Profissional da ABOP e VIII Simpósio Brasileiro de Orientação Vocacional \& Ocupacional. Bento Gonçalves. Resumos... São Paulo: Vetor, 2007, p. 147.

ARIADNE: Guidelines for web-based guidance. European Commission, s.d. Disponível em: (http://www.ariadneproject.org). Acesso em: 18 abr. 2007.

ATITUDE. In: SILVA, B. et al. Dicionário de Ciências Sociais. Rio de Janeiro: Editora da Fundação Getulio Vargas, 1987, p.95.

AZEVEDO, R. N.; ESBROGEO, M. C; MELO-SILVA, L. L. Caracterização sóciodemográfica da clientela atendida pelo serviço de orientação profissional de uma clínica escola universitária. In: I Congresso Latino-americano de Orientação Profissional da ABOP e VIII Simpósio Brasileiro de Orientação Vocacional \& Ocupacional. Bento Gonçalves. Resumos... São Paulo: Vetor, 2007, p. 132.

BALBINOTTI, M. A. A. A noção transcultural de maturidade vocacional na Teoria de Donald Super. Psicologia: Reflexão e Crítica, Porto Alegre, v.16, n.3, p.461-473, 2003.

BALBINOTTI, M. A. A.; TÉTREAU, B. Níveis de maturidade vocacional de alunos de 14 a 18 anos do Rio Grande do Sul. Psicologia em Estudo, Maringá, v.11, n.3, p.551-560, 2006.

BALBINOTTI, M. A. A.; WIETHAEUPER, D.; BARBOSA, M. L.L. Níveis de cristalização de preferências profissionais em alunos do ensino médio. Revista Brasileira de Orientação Profissional, São Paulo, v. 5, n.1, p.15-28, 2004.

BRASIL. Ministério do Trabalho. Secretaria de Mão. Terminologia da formação profissional no sistema nacional de formação de mão-de-obra. Brasília, DF, 1981.

BRIDGES, W. Um mundo sem empregos. Tradução José Carlos Barbosa dos Santos. São Paulo: Makron Books, 1997.

BOHOSLAVSKY, R. Orientação vocacional: a estratégia clínica. São Paulo: Martins Fontes, 1991.

BARDIN, L. Análise de conteúdo. Lisboa: Edições 70, 1988. 
BROWN, D. Career information, career counseling, and career development. Chapel Hill: Pearson Education, 2003.

CARbonero, M. A.; TEJEDOR, E. M. Autoeficácia y Madurez Vocacional. Psicothema, Valladolid, v.16, n.2, p.229-234, 2004.

CAMPERO, G.; FLISFISCH, A.; TIRONE, E.; TOKMAN, V.E. Os atores sociais no novo mundo do trabalho. São Paulo: OIT, 1994.

CARVALHO, M. M. M. Y. Orientação profissional em grupo: teoria e técnica. Campinas: Editorial Psy, 1995.

CASEBEER, A. L.; VERHOEF, M. J. Combinig qualitative and quantitative research methods: considering the possibililities for enhancing the study of chronic disease. Revista Chronic Diseases in Canada, Ottawa, v.18, n.3, 1997.

CASSIE, D.V.W. Career maturation in the context of a mandated intervention at the grade ten level. Dissertation Abstracts International- Section A: Humanities and Social Sciences. Quezon City, v.66, n.10-A, 2006.

CATTANI, A. D. Trabalho e autonomia. Petrópolis: Vozes, 1996.

CIAMPONE, M. H. T. Tecnologias para a gestão do conhecimento: grupo operativo. Revista Mundo da Saúde, São Paulo, v.24, n.5, p.361-365, 2000.

CREED, P. A.; PATTON, W. Differences in career attitude and career knowledge for High School students with and without Paid Work Experience. International Journal for Educational and Vocational Guidance, Netherlands, v.3, p.21-33, 2003.

CREED, P.A.; PATTON, W. The development and validation of a short form of the Australian version of the Career Development Inventory. Australian Journal of Guidance and Counseling, Beaumaris, v.14, n.2, p.125-138, 2004.

D’ACHIARDI, C. A new approach to measuring adolescents' career maturity: Evaluating a career exploration intervention. Dissertation Abstracts International- Section B: The Sciences and Engineering, New York, v.66, n.11-B, 2006.

DELGADO, J. M.; GUITÉRREZ, J. Métodos y técnicas cualitativas de investigación em ciencias sociales. Madrid: Ed. Sinteses, 1995.

DIAS, M. L. Profissão: no rumo da vida. São Paulo: Editora Ática, 2002.

DHILLON, U.; KAUR, R. Psychological correlatos of career maturity: A comparative study of public and governmente school children. Journal of the Indian Academy of Applied Psychology, Calcutta, v.31, n.1-2, p. 69-74, 2005.

DOSSIÊ Universo Jovem 3. MTV Brasil, 2005. Disponível em: (http://www.ibta.com.br) Acesso em: 18 abr. 2007. 
DRUCKER, P. F. O melhor de Peter Drucker: o homem, a administração e a sociedade. São Paulo: Ed. Nobel, 2002.

DWYER, T, et al. Desvendando mitos: os computadores e o desempenho no sistema escolar. Educação e Sociedade, Campinas, v.28, n. 101, 2007.

ESBROECK, R.V. Editorial. Internacional Journal for Educational and Vocational Guidance, Netherlands, v.2, n.3, p.137-138, 2002.

ESBROGEO, M. C; MELO-SILVA, L. L. Em plena era da informática os adolescentes estão informados? In: I Congresso Latino-americano de Orientação Profissional da ABOP e VIII Simpósio Brasileiro de Orientação Vocacional \& Ocupacional. Bento Gonçalves. Resumos... São Paulo: Vetor, 2007, p. 39.

FERRETTI, C. J. Uma nova proposta em orientação profissional. São Paulo: Cortez, 1988.

FLOURI, E.; BUCHANAN, A. The role of work-related skills and career role models in adolescent career maturity. The Career Development Quarterly, Alexandria, v.51, n.1, p.36-43, 2002.

FORRESTER, V. O horror econômico. São Paulo: Editora UNESP, 1997.

FOUAD, N.A. Annual review 1991-1993: vocational choice: decision making, assesment and intervention. Journal of Vocational Behavior, New York, v.45, n.2, p.125-76, 1994.

GARCIA, M; WAISBROT, D. Una vuelta en espiral dialéctica. Argentina: Centro Editor Argentino, 1981.

GUARNIERI, F. V.; MELO-SILVA, L. L. Ações afirmativas na educação superior: rumos da discussão nos últimos cinco anos. Revista Psicologia e Sociedade, Rio grande do Sul, v.19, n $1,2007$.

GUARNIERI, F. V. Cotas Universitárias: perspectivas de estudantes em situação de vestibular. 131p. Dissertação (Mestrado em Psicologia) - Faculdade de Filosofia Ciências e Letras de Ribeirão Preto, Universidade de São Paulo, 2008.

GUIA DO ESTUDANTE, Vestibular 2006. São Paulo: Editora Abril, 2006.

GUIA DE PROFISSÕES, Universidade Estadual Paulista (UNESP), São Paulo: Fundação Vunesp, 2005.

GUICHARD, J.; HUTEAU, M. Psicología da orientação. Lisboa: Instituto Piaget, 2001.

GORE Jr., P. A.; LEUWERKE, W. C. Information technology for career assessement on the internet. Journal of Career Assessment, New York, v.8, p. 3-19, 2000.

GÜNTHER, H. Como elaborar um questionário. In: PASQUALI, L. Instrumentos psicológicos: manual prático de elaboração. Brasília: LabPAM; IBAPP, 1999, p. 231-258. 
HASAN, B. Career maturity of Indian adolescentes as a function of self-concept, Vocational aspiration and gender. Journal of the Indian Academy of Applied Psychology, Calcutta, v.32, n.2, p. 169-176, 2006.

HENRIQUES, S. M. O. O paradigma de relações entre o adolescente e as tecnologias. Tese (Mestrado em Engenharia de Produção) - Universidade Federal de Santa Catarina, Florianópolis, 2003.

HUTZ, C. S.; BARDAGI, M. P. Indecisão profissional, ansiedade e depressão na adolescência: a influência dos estilos parentais. Psico-USF, São Paulo, v.11, n.1, 2006.

INFORMAÇÃO PROFISSIONAL. In: SILVA, B. et al. Dicionário de Ciências Sociais. Rio de Janeiro: Editora da Fundação Getulio Vargas, 1987, p.851.

JACQUEMIN, A. O BBT-Br: Teste de Fotos de Profissões: normas, adaptação brasileira, estudos de caso. São Paulo: CETEPP, 2000.

JACQUEMIN, A.; OKINO, E. T. K.; NOCE, M. A.; ASSONI, R. F.; PASIAN, S. R. O BBT-Br: feminino: Teste de Fotos de Profissões: adaptação brasileira, normas e estudos de caso. São Paulo: Centro Editor de Testes e Pesquisas em Psicologia, 2006.

KARL, F. R. O Moderno e o modernismo, a soberania do artista 1885-1925. Rio de Janeiro: Imago, 1985.

KING, S. Background and family variables in a casual model of career maturity: comparing hearing and hearing-impaired adolescents. The Career Development Quarterly, Alexandria, v.38, n.3, p.240-260, 1990.

LEE, K.H. A cross-cultural study of the career maturity of Korean and United States High Scholl students. Journal of Career Development, Thousand Oaks, v.28, n.1, p 43-57, 2001.

LEGUM, H. L.; HOARE, C. H. Impact of a career intervention on at-risk middle school students'Career Maturity levels, academic achievement and self-esteem. Professional School Counseling, Alexandria, v.8, n.2, p.148-155, 2004.

LEVENFUS, R. S. Geração Zapping e o sujeito da orientação vocacional. In: LEVENFUS, R. S.; SOARES, D. H. P. Orientação vocacional/ocupacional, novos achados teóricos, técnicos e instrumentais para a clínica, a escola e a empresa. Porto Alegre: Artmed Editora, 2002, p.51-60.

LEVENFUS, R. S.; NUNES, M. L. T. Principais temas abordados por jovens centrados na escolha profissional. In: LEVENFUS, R. S.; SOARES, D. H. P. Orientação vocacional/ ocupacional, novos achados teóricos, técnicos e instrumentais para a clínica, a escola e a empresa. Porto Alegre: Artmed Editora, 2002, p.61-78.

LEVISKY, D. L. Adolescência, reflexões psicanalíticas. São Paulo: Casa do Psicólogo, 1998. 
LOBATO, C. R. P. S.; KOLLER, S. H. Maturidade vocacional e gênero: Adaptação e uso do Inventário Brasileiro de Desenvolvimento Profissional. Revista Brasileira de Orientação Profissional, São Paulo, v.4, n.1-2, p.57-69, 2003.

LOBO, S. M. A. Programa de informação profissional: uma atividade de orientação profissional na escola. Tese (Mestrado) - Pontifícia Universidade Católica de São Paulo, São Paulo, 2005.

LOOSLI, L. Orientação Profissional: avaliação do atendimento na visão dos familiares de ex-clientes. Monografia (Conclusão de Curso) - Programa Optativo de Bacharelado em Psicologia, Faculdade de Filosofia, Ciências e Letras de Ribeirão Preto, Universidade de São Paulo, São Paulo, 2003.

LUZ FILHO, S. S. Escolha Profissional, projeto de vida e de carreira. Canoas: Editora Masai, 2002.

LYON, D. Pós-modernidade. São Paulo: Paulus, 1988.

MAHL, A. C.; SOARES, D. H. P.; OLIVEIRA NETO, E. Programa de orientação profissional intensivo, outra forma de fazer orientação profissional. São Paulo: Vetor Editora, 2005.

MATTOSO, J. O Brasil desempregado. São Paulo: Fundação Penseu Abramo, 1999.

MEDICO, M. D. PIP - Programa de Informação Profissional. São Paulo: Casa do Psicólogo, 2005.

MELO-SILVA, L. L.; JACQUEMIN, A. Intervenção em orientação vocacional/profissional: avaliando processos e resultados. São Paulo: Vetor Editora, 2001.

MELO-SILVA, L. L.; PEREIRA, J. M. F. Escolha da carreira: conversa na cozinha. Ribeirão Preto: Maxicolor, 2002.

MELO-SILVA, L. L.; OLIVEIRA, J. C.; COELHO, R. S. Avaliação da orientação profissional no desenvolvimento da maturidade na escolha da profissão. Psic- Revista de Psicologia da Vetor Editora, São Paulo, v.3, n.2, p.44-53, 2002.

MELO-SILVA, L. L. Ética e competência na prática da orientação profissional. In: MELOSILVA, L. L. et al. Arquitetura de uma Ocupação. São Paulo: Vetor, 2003, v.1, p. 69-90.

MELO-SILVA, L. L.; ALMEIDA, F.; LOOSLI, L.; FRAGA, L. B. Orientación Vocacional en Brasil: siete años de evaluación de un servicio. In: Conferencia Internacional: orientación, inclusión social y desarrollo de la carrrera. A Coruña. Anais... A Coruña: 2004, p. 1223-1226.

MELO-SILVA, L. L. Orientação Profissional em uma clínica-escola de Psicologia. In: MELO-SILVA, L. L.; SANTOS. M. A.; SIMON, C.P. Formação em Psicologia: serviçosescola em debate. São Paulo: Vetor, 2005, p.171-196. 
MELO-SILVA, L. L.; LASSANCE, M. C. P.; SOARES, D. H. P. A orientação profissional no contexto da educação e trabalho. Revista Brasileira de Orientação Profissional, São Paulo, v.5, n.2, p.31-52, 2004.

MINAYO, M. C. S. Avaliação por triangulação de métodos, abordagem de programas sociais. Rio de Janeiro: Editora Fiocruz, 2005.

MORIN, E. Os sete saberes à educação do futuro. 5: ed. São Paulo: Cortez Editora, 2002.

MÜLLER, M. Orientação vocacional: contribuições clínicas. Porto Alegre: Artes Médicas, 1988.

NEIVA, K. M. C. Escala de maturidade para a escolha profissional (EMEP): estudo de validade e fidedignidade. Revista UNIb, São Paulo, v.6, p.43-61, 1998.

NEIVA, K. M. C. Manual: escala de maturidade para a escolha profissional (EMEP). São Paulo: Vetor Editora, 1999.

NEIVA, K. M. C. EMEP: Escala de Maturidade para a Escolha Profissional. Revista PSIC, São Paulo, v.1, n.3, p.28-33, 2000.

NEIVA, K. M. C. Escala de maturidade para a escolha profissional (EMEP). In: LEVENFUS, R. S.; SOARES, D. H. P. Orientação vocacional/ocupacional, novos achados teóricos,técnicos e instrumentais para a clínica, a escola e a empresa. Porto Alegre: Artmed Editora, 2002, p.239-246.

NEIVA, K. M. C. Critérios para a escolha profissional. São Paulo: Vetor, 2003a.

NEIVA, K. M. C. A maturidade para a escolha profissional: uma comparação entre alunos do ensino médio. Revista Brasileira de Orientação Profissional, São Paulo, v.4, n.1-2, p.97103, 2003b.

NEIVA, K. M. C.; SILVA, M. B.; MIRANDA, V. R.; ESTEVES, C. Um estudo sobre a Maturidade para a escolha Profissional de alunos do ensino Médio, Revista Brasileira de Orientação Profissional, São Paulo, v. 6, n.1, p.1-14, 2005.

NILES, S. G. Annual review: practice and Research in Career counseling and development. The Career Development Quartely, Alexandria, v.46, p.115-41, 1997.

NILES, S. G.; HARRIS-BOWLSBEY, J. Career Development Interventions in the 21 st Century. Ohio: Pearson, 2005.

OLIVEIRA, M. C.; GUIMARÃES, V. F.; COLETA, M. F. D. Modelo desenvolvimentista de avaliação e orientação de carreira proposto por Donald Super. Revista Brasileira de Orientação Profissional, São Paulo, v. 7, n.2, p.11-18, 2006.

PATTON, W.; CREED, P. A. Developmental issues in Career Maturity and career decision status. The Career Development Quartely, Alexandria, v.49, n.4, p.336-351, 2001. 
PATTON, W.; LOKAN, J. Perspectives on Donald Super's Construct of Career Maturity. International Journal for Educational and Vocational Guidance, Netherlands, v.1, p. 31-48, 2001.

PATTON, W.; BARTRUM, D. A.; CREED, P. A. Gender differences for optimism, selfesteem, expectations and goals in predicting career planning and exploration in adolescents. International Journal for Educational and Vocational Guidance, Netherlands, v. 4, p.193209, 2004.

PEARCE, W. B. Novos modelos e metáforas comunicacionais: a passagem da teoria à Prática, do objetivismo ao construcionismo social e da representação à reflexividade. In: SCHNITMAN, D. F. Novos paradigmas, cultura e subjetividade. Porto Alegre: Artes Médicas, 1996, p.172-183.

PICHON-RIVIÈRE, E. O processo grupal. 5: ed. São Paulo: Martins Fontes, 1994.

PICHON-RIVIÈRE, E. Teoria do vínculo. 5: ed. São Paulo: Martins Fontes, 1995.

PIMENTA, S. G. Orientação vocacional e decisão: estudo crítico da situação no Brasil. 2: ed. São Paulo: Ed Loyola, 1981.

POWELL, D. F.; LUZZO, A. Evaluating factors associated with the Career Maturity of High School Students. The Career Development Quartely, Alexandria, v. 47, n. 2, p. 145-158, 1998.

QUIROGA, A. P. Enfoques y perspectivas en psicología social. Argentina, Buenos Aires: Ediciones Cinco,1994.

REBOLLO, E. Información y conocimiento en la sociedad de la información. In: MELO, J. M. (Org.). Sociedade do conhecimento: aportes latino-americanos. São Bernardo do Campo: UMESP, 2005, p.193.

REILE, D. M.; HARRIS-BOWLSBEY, J. Using the internet in career planning and assessement. Journal of Career Assessment, New York, v.8, n.1, p. 69-84, 2000.

RIOS, T. A. Ética e competência. São Paulo: Cortez, 1993.

ROBINSON, N. K.; MEYER, D.; PRINCE, J. P.; McLEAN, C.; LOW, R. Mining the internet for career information: A model approach for college students. Journal of Career Assessment, New York, v.8, n.1, p 37-54, 2000.

SAMPSON, J.P. Integrating internet-based distance guidance with services provided in career centers. The Career Development Quartely, Alexandria, v.47, n.3, p.243-254, 1999.

SAMPSON, J. P.Jr.; LUMSDEN, J. A. Ethical issues in the design and use of internet-based career assessment, Journal of Career Assessment, New York, v.8, n.1, p.21-35, 2000.

SAMPSON, J.P. Quality and ethics in internet-based guidance. Internacional Journal for Educational and Vocational Guidance, Netherlands, v.2, n.3, p.157-171, 2002. 
SANTOS, M. A.; MELO-SILVA, L. L. JUNTA, A.L. Perfil do usuário de um serviço de orientação em clínica-escola: análise comparativa de três anos de atendimento. In: CICLO DE ESTUDOS EM SAÚDE MENTAL, 5., 1997, Ribeirão Preto, Programas e Resumos... Ribeirão Preto, Faculdade de Medicina da Universidade de São Paulo, 1997, p.41.

SARRIERA, J. C.; SCHIESSL, C. S. Refletindo a questão do ingresso ao ensino superior: dificuldades e expectativas dos jovens de ensino médio. In: SARRIERA, J. C.; ROCHA, K. B.; PIZZINATO, A. Desafios do mundo do trabalho. Porto Alegre: EDIPUCRS, 2004, p. 33-71.

SAVARD, R.; GINGRAS, M.; TURCOTTE, M. Delivery of career development information in the context of information computer technology. Internacional Journal for Educational and Vocational Guidance, Netherlands, v.2, n.3, p.173-191, 2002.

SAVICKAS, M. L. A developmental perspective on vocational behaviour: career patterns, saliente, and themes. Internacional Journal for Educational and Vocational Guidance, Netherlands, v.1, p.49-57, 2001.

SAVICKAS, M. L., ESBROECK, R. V., HERR, E. L. The Internationalization of Educational and Vocational Guidance. The Career Development Quartely, Alexandria, v. 54, n.1, p.7785, 2005.

SCHMITT-RODERMUND, E.; SILBEREISEN, R. K. Career Maturity determinants: Individual development, social context and historical time. The Career Development Quartely, Alexandria, v.47 ,n.1, p.16-31, 1998.

SHEVLIN, M.; MILLAR, R. Career education: an application of latent growth curve modeling to career information-seeking behaviour of school pupils. British Journal of Educational Psychology, London, v.76, n.1, p.141-153, 2006.

SIEBIGER, R. H. Orientação e informação profissional via internet: uma proposta. Universidade de Brasília, s.d. Disponível em: (www.abed.org.br). Acesso em 20 fev. 2007.

SILVA, J. M. T. Avaliação da maturidade de carreira. In: LEITÃO, L. M. Avaliação psicológica, em orientação escolar e profissional. Coimbra: Quarteto, 2004, p.266-316.

SILVA, L. M.; VENTURINI. F. P.; MELO-SILVA, L. L. Carta que dizem muito: pais e filhos na orientação vocacional. In: SIMON, C. P.; MELO-SILVA, L. L.; SANTOS. M. A. Formação em Psicologia: desafios da diversidade na pesquisa e na prática. São Paulo: Vetor, 2005, p.307-320.

SOARES-LUCCHIARI, D. H. P. S. Pensando e vivendo a orientação profissional. São Paulo: Summus, 1993.

SOARES-LUCCHIARI, D. H. P. S. Uma abordagem genealógica a partir do genoprofissiograma e do teste dos três personagens. In: LEVENFUS, R. S. Psicodinâmica da escolha profissional. Porto Alegre: Artes Médicas, 1997, p.135-160.

SPACCAQUERCHE, M.E. Orientação Profissional online: uma experiência em processo. Revista Brasileira de Orientação Profissional, São Paulo, v.6, n.1, p. 63-75, 2005. 
SPOKANE, A. R. Avaliação das intervenções de carreira. In: LEITÃO, L. M. Avaliação Psicológica, em orientação escolar e profissional. Coimbra: Quarteto, 2004, p. 455-473.

SWANSON, J. L.; FOAUD, N. A. Career theory and practice: learning through case studies. United States of America: Sage Publications, 1999.

TARGINO, M. G. The internet and the society: just another dream? Ciência e Cultura, Journal of the Brazilian Association for the Advancement of Science, São Paulo, v.49,n.4,p.252-257,1997.

TAVEIRA, M. C. Exploração e desenvolvimento vocacional de jovens. Portugal-Braga: Editora Lusografe, 2000.

TERÊNCIO, M. G.; SOARES, D. H. P. A internet como ferramenta para o desenvolvimento da identidade profissional. Psicologia em Estudo, Maringá. v.8, n.2, p.139-145, 2003.

TRUSTY, J. Relationship of parental involvement in teens' career development to teens'attitudes, perceptions, and behavior. Journal of Research and Development in Education, Germantown, v. 30, n. 1, p. 63-69, 1996.

WATTS, A. G. The role of information and communication technologies in integrated career information and guidance systems: a policy perspective. Internacional Journal for Educational and Vocational Guidance, Netherlands, v.2, n.3, p.139-155, 2002.

WATZLAWICK, P.; BEAVIN, J.H.; JACKSON, D.D. Pragmática da comunicação humana. São Paulo: Editora Cultrix, 1967.

WHITAKER, D. C. A. A escolha da carreira. São Paulo: Editora Moderna, 1985.

WHITAKER, D. C. A. Escolha da carreira e globalização. São Paulo: Ed. Moderna, 1997. 


\title{
APÊNDICES
}

\section{APÊNDICE A - QUESTIONÁRIO DE INFORMAÇÃO PROFISSIONAL (QIP)}

\author{
UNIVERSIDADE DE SÃO PAULO \\ FACULDADE DE FILOSOFIA, CIÊNCIAS E LETRAS DE RIBEIRÃO PRETO \\ Centro de Pesquisa e Psicologia Aplicada (CPA) \\ Serviço de Orientação Profissional (SOP)
}

\section{QUESTIONÁRIO DE INFORMAÇÃO PROFISSIONAL - QIP $O$ que os adolescentes sabem sobre profissões e carreiras?}

Este questionário objetiva verificar se os adolescentes estão buscando e tendo acesso às informações sobre profissões e carreiras. Assim sendo, solicitamos que você responda sinceramente aos enunciados a seguir.

1. A propósito desse assunto, você acredita que os adolescentes estão suficientemente informados sobre profissões? ( ) sim ( ) não Comente

2. Você acredita que a informação profissional pode ajudá-lo(a) na tomada de decisão vocacional?
( ) $\operatorname{sim}$
( ) não

Comente

3. Quais recursos ou instrumentos você utiliza para obter informações relativas às profissões e carreiras? Faça um círculo em volta do número que melhor representa sua avaliação sobre o quanto você utiliza cada um dos instrumentos abaixo discriminados.

\begin{tabular}{|l|l|l|l|l|l|}
\hline Instrumentos & NUNCA & RARAMENTE & ÀS VEZES & $\begin{array}{l}\text { FREQUENTE- } \\
\text { MENTE }\end{array}$ & SEMPRE \\
\hline internet & 1 & 2 & 3 & 4 & 5 \\
\hline Guias & 1 & 2 & 3 & 4 & 5 \\
\hline Livros & 1 & 2 & 3 & 4 & 5 \\
\hline Revistas & 1 & 2 & 3 & 4 & 5 \\
\hline Programas de televisão & 1 & 2 & 3 & 4 & 5 \\
\hline Programas de rádio & 1 & 2 & 3 & 4 & 5 \\
\hline Filmes & 1 & 2 & 3 & 4 & 5 \\
\hline Outros. Especifique: & 1 & 2 & 3 & 4 & 5 \\
\hline
\end{tabular}

Comente 
4. Especificamente sobre o uso da Internet (caso você faça uso) gostaríamos de saber mais detalhadamente:

\subsection{Quais os sites que você mais acessa?}

4.2. Qual é o local de onde você mais acessa a internet? Faça um círculo em volta do número que melhor representa sua situação, no quadro abaixo, em função da freqüência de acesso.

\begin{tabular}{|l|l|l|l|l|l|}
\hline Locais & NUNCA & RARAMENTE & ÀS VEZES & $\begin{array}{l}\text { FREQUENTE- } \\
\text { MENTE }\end{array}$ & SEMPRE \\
\hline Casa & 1 & 2 & 3 & 4 & 5 \\
\hline Escola & 1 & 2 & 3 & 4 & 5 \\
\hline Trabalho & 1 & 2 & 3 & 4 & 5 \\
\hline Trabalho dos pais & 1 & 2 & 3 & 4 & 5 \\
\hline Lan house & 1 & 2 & 3 & 4 & 5 \\
\hline Casa de amigos & 1 & 2 & 3 & 4 & 5 \\
\hline Acesso público. Qual? & 1 & 2 & 3 & 4 & 5 \\
\hline Outros. Especifique: & 1 & 2 & 3 & 4 & 5 \\
\hline
\end{tabular}

Comente

4.3. Usualmente, acessa sites com qual (quais) objetivo(s)? Faça um círculo em volta do número que melhor representa sua situação.

\begin{tabular}{|l|l|l|l|l|l|}
\hline Objetivo(s) ou finalidades & NUNCA & RARAMENTE & ÀS VEZES & $\begin{array}{l}\text { FREQUENTE- } \\
\text { MENTE }\end{array}$ & SEMPRE \\
\hline Jogar & 1 & 2 & 3 & 4 & 5 \\
\hline Realizar pesquisa escolar & 1 & 2 & 3 & 4 & 5 \\
\hline Comunicar-se com colegas & 1 & 2 & 3 & 4 & 5 \\
\hline Fazer compras & 1 & 2 & 3 & 4 & 5 \\
\hline Fazer novos relacionamentos & 1 & 2 & 3 & 4 & 5 \\
\hline Buscar informações gerais & 1 & 2 & 3 & 4 & 5 \\
\hline Buscar informação sobre profissões & 1 & 2 & 3 & 4 & 5 \\
\hline Buscar informações sobre universidades & 1 & 2 & 3 & 4 & 5 \\
\hline Outros. Especifique: & 1 & 2 & 3 & 4 & 5 \\
\hline
\end{tabular}

Comente

4.4. Caso você utilize a internet como é o uso para busca de informação profissional

- passa quantas vezes por semana? vezes por semana

- qual a média de horas por dia? horas por dia 
5. Considerando suas preferências gostaríamos de saber qual (is) profissão(ões) desperta(m) mais o seu interesse?

5.1. O que sabe sobre essas profissões?

5.2. E como obteve tais informações?

5.3. Você busca (buscou) informação profissional com alguma pessoa?
( ) $\operatorname{sim}$
( ) não

5.4. Em caso afirmativo, com quem você tem obtido informações?

\begin{tabular}{|l|l|l|l|l|l|}
\hline Pessoas & NUNCA & RARAMENTE & ÀS VEZES & $\begin{array}{l}\text { FREQUENTE } \\
\text {-MENTE }\end{array}$ & SEMPRE \\
\hline Colegas & 1 & 2 & 3 & 4 & 5 \\
\hline Professores & 1 & 2 & 3 & 4 & 5 \\
\hline Familiares & 1 & 2 & 3 & 4 & 5 \\
\hline Religiosos & 1 & 2 & 3 & 4 & 5 \\
\hline Profissionais. Quais? & 1 & 2 & 3 & 4 & 5 \\
\hline $\begin{array}{l}\text { Serviços de orientação profissional. } \\
\text { Qual? }\end{array}$ & 1 & 2 & 3 & 4 & 5 \\
\hline Outros. Especifique: & 1 & 2 & 3 & 4 & 5 \\
\hline
\end{tabular}

Comente

6. O que você sabe sobre as seguintes formas de acesso à Universidade?

6.1.Vestibular

6.2. Exame Nacional do Ensino Médio (ENEM)

6.3. Sistema de cotas

6.4.Programa Universidade para todos (PROUNI)

6.5.Outros processos seletivos 
7. O que você conhece sobre inscrições para o vestibular? E sobre taxa de isenção?

8. Você já verificou a relação candidato /vaga de carreiras universitárias?
( ) $\operatorname{sim}$
( ) não

Comente

9. Que tipo de informação você tem sobre oportunidades de trabalho no Brasil?

10. Gostaríamos de saber qual a sua opinião sobre a qualidade da informação profissional que você acessou:

10.1. Qual o proveito que você tem obtido com as informações?

10.2. Ainda são necessárias outras informações? Quais?

11. O que você deseja ser? Registre suas expectativas em relação ao seu futuro, ao seu projeto de vida.

12. Avalie este questionário, quanto à qualidade para examinar o que os adolescentes sabem sobre profissões e carreiras?
( ) 1- muito fraco
( ) 2 - fraco
( ) 3- regular
( ) 4- bom
( ) 5- muito bom
( ) 6- não sei

Comente

Nome:

Insc/Pront:

Idade:

Escola

)pública ( )particular

Série:

Data:

Grupo:
( ) Pré OP
( ) Pós OP 


\title{
APÊNDICE B - CARTA DE APRESENTAÇÃO
}

\author{
UNIVERSIDADE DE SÃO PAULO \\ FACULDADE DE FILOSOFIA, CIÊNCIAS E LETRAS \\ DEPARTAMENTO DE PSICOLOGIA E EDUCAÇÃO \\ Programa de Pós-Graduação e Psicologia
}

\section{CARTA DE APRESENTAÇÃO}

Tem esta o objetivo de convidá-lo(a) a participar da pesquisa intitulada
“INFORMAÇÃO E MATURIDADE PROFISSIONAL: O GRUPO OPERATIVO
COMO FACILITADOR DA COMUNICAÇÃO” sob a responsabilidade da pesquisadora Marystella Carvalho Esbrogeo, sob orientação da Profa Dra. Lucy Leal Melo-Silva. A pesquisa pretende examinar o nível de informação a cerca das profissões e mercado de trabalho e sua relação com a maturidade na escolha profissional, em adolescentes submetidos ao processo de Orientação Profissional em grupo atendidos no Serviço de Orientação Profissional (SOP) da Faculdade de Filosofia, Ciências e Letras de Ribeirão Preto. As atividades e discussões serão desenvolvidas em grupo, coordenado pela pesquisadora, objetivando facilitar a tomada de decisão e/ou a facilitação da escolha da carreira.

Será uma pesquisa sem fins lucrativos, totalmente gratuita, que não oferece nenhum risco à saúde, não exige nada a além da participação espontânea nas reuniões previamente agendadas. Não será realizado nenhum tratamento ou qualquer outro procedimento, que não seja relacionado com as informações profissionais e a tomada de decisão vocacional. Serão utilizados instrumentos e técnicas do domínio da Orientação Vocacional: entrevistas, aplicação de testes de maturidade e de interesse, questionários de informação, fichas de atividades, guias de profissões, consulta em sites, e técnica grupais e expressivas.

Os grupos serão realizados uma vez por semana, com duração de duas horas, de acordo com a disponibilidade dos integrantes. E terão a duração de 12 encontros, aproximadamente 3 meses. Aceitando colaborar com este estudo, sua participação consistirá em participar do grupo no horário combinado. É importante que dê ciência assinando o termo de consentimento, parte integrante desta carta, e também esta carta. Para os participantes com 
idade inferior a 18 anos é preciso ainda o consentimento de um de seus pais ou responsável, expressamente manifesto com a devida assinatura no referido termo.

Caso não seja de seu interesse, por favor, devolva em branco e seu atendimento será realizado em outro grupo.

Em caso de dúvidas, você pode entrar em contato conosco através do telefone e e-mail abaixo.

Desde já agrademos sua atenção,

\section{Concordo}

Assinatura do cliente e/ou pai / mãe ou responsável

- Marystella Carvalho Esbrogeo - Pesquisadora do Programa de Pós-Graduação em Psicologia, da Faculdade de Filosofia, Ciências

e Letras (FFCLRP-USP). E-mail: marystella@terra.com.br

- Profa. Dra. Lucy Leal Melo-Silva - Pesquisadora responsável. Docente do Departamento de Psicologia e Educação da FFCLRP-USP. E-mail: lucileal@ffclrp.usp.br

- Contatos com as pesquisadoras: 3602-3641 / 3602-3739 / 3602-3789 


\section{APÊNDICE C - TERMO DE CONSENTIMENTO LIVRE E ESCLARECIDO}

\section{TERMO DE CONSENTIMENTO LIVRE E ESCLARECIDO}

$\mathrm{Eu}$ abaixo assinado, tendo sido devidamente esclarecido sobre todas as condições que constam do documento "Carta de Apresentação", referente ao Projeto de Pesquisa intitulado “INFORMAÇÃO E MATURIDADE PROFISSIONAL: O GRUPO OPERATIVO COMO FACILITADOR DA COMUNICAÇÃO” que tem como pesquisadora responsável, Marystella Carvalho Esbrogeo, especialmente no que diz respeito ao objetivo da pesquisa, declaro que tenho pleno conhecimento dos direitos e das condições que me foram assegurados e concordo em participar, como voluntário (a), desta pesquisa.

Estou ciente de que minha participação será para auxiliar na compreensão de questões pertinentes à informação e maturidade profissional no processo de tomada de decisão, cujos dados serão obtidos no atendimento em grupo. E que como beneficio, poderei usufruir o atendimento em grupo, que poderá facilitador na tomada de decisão vocacional.

Estou ciente de que este estudo possui a finalidade de pesquisa, sendo que os dados obtidos serão utilizados em publicações científicas, sem que os participantes sejam identificados.

Declaro ainda que:

1) estou aceitando voluntariamente participar deste estudo, não tendo sofrido nenhuma forma de pressão para isso;

2) se desejar posso me recusar a participar do estudo a qualquer momento; ou interromper minha participação. Caso não concordar em participar deste estudo, será mantida a minha possibilidade de ter outros atendimentos no serviço sem prejuízo ou qualquer outra penalização;

3) será garantidos o sigilo e a privacidade quanto aos meus dados confidenciais;

4) não serão cobrados honorários de qualquer espécie, nem receberei qualquer tipo de pagamento por participar da pesquisa, sendo tudo gratuito e voluntário.

Ribeirão Preto, 
- Marystella Carvalho Esbrogeo - Pesquisadora do Programa de Pós-Graduação em Psicologia, da Faculdade de Filosofia, Ciências e Letras (FFCLRP-USP). E-mail: marystella@terra.com.br

- Profa. Dra. Lucy Leal Melo-Silva - Pesquisadora responsável. Docente do Departamento de Psicologia e Educação da FFCLRP-USP. E-mail: lucileal@ffclrp.usp.br

- Contatos com as pesquisadoras: 3602-3641 / 3602-3739 / 3602-3789 


\title{
APÊNDICE D - CARTA COMITÊ DE ÉTICA
}

\author{
UNIVERSIDADE DE SÃO PAULO \\ FACULDADE DE FILOSOFIA, CIÊNCIAS E LETRAS DE RIBEIRÃO PRETO \\ COMITÊ DE ÉTICA EM PESQUISA - CEP
}

OF.CEP/SEAC.122.2005/FFCLRP/22.12.2005

Prezado(a) Senhor(a):

Comunicamos a V. Sa. que o trabalho intitulado "Informação e Maturidade Profissional: O Grupo Operativo como Facilitador da Comunicação" foi analisado pelo Comitê de Ética em Pesquisa da FFCLRP-USP, e, enquadrado na categoria: $\underline{\text { APROVADO }}$ de acordo com o Processo CEP-FFCLRP $\mathrm{n}^{\circ}$ 232/2005 - 2005.1.1862.59.2

Aproveitamos a oportunidade para apresentar nossos protestos de estima e consideração.

Atenciosamente,

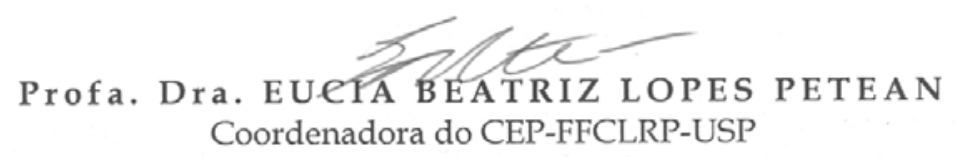

Coordenadora do CEP-FFCLRP-USP

Ilustríssimo(a) Senhor(a)

MARYSTELLA CARVALHO ESBROGEO

Aluna do Programa de PG em Psicologia desta FFCLRP-USP

C.C.: Profa. Dra. LUCY LEAL MELO SILVA

Docente do Departamento de Psicologia e Educação

desta Faculdade

CEP-FFCLRP-USP - Fone: (016) 602-3653 - Fax: (016) 633-5015 - E.mail: coetp@ffelrp.usp.br Avenida Bandeirantes, 3900 - Bloco A - 14040-901 - Ribeirão Preto - SP - Brasil 


\section{APÊNDICE E - CARTA COMITÊ DE ÉTICA}

Universidade de São Paulo

Faculdade de Filosofia, Ciências e Letras de Ribeirão Preto

Departamento de Psicologia e Educação

Centro de Psicologia Aplicada

Campus de Ribeirão Preto

Ribeirão Preto, 21 de maio de 2008.

Ilma. Sra.

Profa. Dra. Adelaide de Almeida

DD. Coordenadora do Comitê de Ética em Pesquisas

com seres humanos - FFCLRP - USP

Assunto: alteração de título

Prezada Senhora:

Tem esta o objetivo de informar que o projeto de Mestrado intitulado' "Informação e Maturidade: o Grupo Operativo como facilitador da Comunicação", de Marystella Carvalho Esbrogeo, analisado pelo Comitê de Ética em Pesquisa da FFCLRP-USP e, enquadrado na categoria APROVADO, de acordo com o Processo CEP-FFCLRP ${ }^{\circ}$ 232/2005 - 2005.1.1862.59.2, teve o seu título alterado para "Avaliação da orientação profissional em grupo: o papel da informação no desenvolvimento da maturidade para a escolha da carreira". A mudança foi realizada a fim de retratar melhor o objeto de estudo. Cumpre ainda esclarecer que o referido estudo foi concluído e encontra-se na etapa final (revisão e impressão) para a Defesa da Dissertação.

Contando com o apoio de V. Sa., para as providências necessárias, subscrevemos com elevados protestos de estima e consideração.

Atenciosamente,

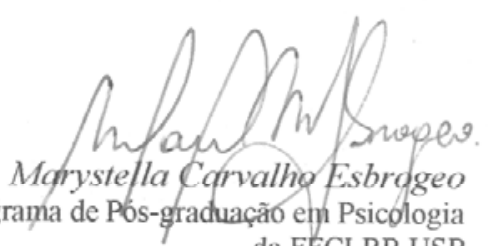
da FFCLRP-USP

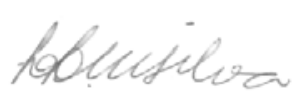

Profa. Dra. Lucy Leal Melo Silva Orientadora e Docente do Departamento de Psicologia e Educação da FFCLRP-USP 


\begin{abstract}
ANEXO
ANEXO A - AUTORIZAÇÃO PARA ORIENTAÇÃO PROFISSIONAL

FACULDADE DE FILOSOFIA, CIÊNCIAS E LETRAS DE RIBIERÃO PRETO

DEPARTAMENTO DE PSICOLOGIA E EDUCAÇÃO

CENTRO DE PSICOLOGIA APLICADA - CPA

Serviço de Orientação Profissional
\end{abstract}

\title{
AUTORIZAÇÃO PARA ORIENTAÇÃO PROFISSIONAL
}

Eu,

[nome cliente]

estou de acordo com a Orientação Profissional que será realizada, assim como, estou ciente de que os registros dos atendimentos pertencem ao Departamento de Psicologia e Educação da FFCLRP-USP e podem, eventualmente, ser utilizados como material de aulas, trabalhos científicos a serem divulgados em congressos e publicados em revistas ou livros especializados, resguardando-se o devido sigilo quanto à identificação do cliente.

Ribeirão Preto,

Assinatura do cliente

Eu,

[nome do pai ou responsável se menor de 18 anos]

estou de acordo com os termos acima mencionados. 